This document was prepared in conjunction with work accomplished under Contract No. DE-AC09-96SR18500 with the U. S. Department of Energy.

\title{
DISCLAIMER
}

This report was prepared as an account of work sponsored by an agency of the United States Government. Neither the United States Government nor any agency thereof, nor any of their employees, nor any of their contractors, subcontractors or their employees, makes any warranty, express or implied, or assumes any legal liability or responsibility for the accuracy, completeness, or any third party's use or the results of such use of any information, apparatus, product, or process disclosed, or represents that its use would not infringe privately owned rights. Reference herein to any specific commercial product, process, or service by trade name, trademark, manufacturer, or otherwise, does not necessarily constitute or imply its endorsement, recommendation, or favoring by the United States Government or any agency thereof or its contractors or subcontractors. The views and opinions of authors expressed herein do not necessarily state or reflect those of the United States Government or any agency thereof. 
Key Words:

Treated-Feed Evaporator

Melter Feed, LAW Glass

Retention:

Permanent

Key WTP R\&T References:

Test Specification 24590-LAW-TSP-RT-02-015

Test Plan WSRC-TR-2003-00107

Test Exceptions

24590-WTP-TEF-RT-03-077

24590-LAW-TEF-RT-04-0001

R\&T Focus Area

Pretreatment and Vitrification

Test Scoping Statements S-54, S-57, S-71

\section{EVAPORATION, RHEOLOGY, AND VITRIFICATION OF A PRETREATED RADIOACTIVE HANFORD TANK 241-AN-104 SAMPLE MIXED WITH SIMULATED LAW SBS RECYCLE}

Mark L. Crowder, 773-A

Erich K. Hansen, 999-W

Charles L. Crawford, 773-41A

William E. Daniel, Jr., 999-W

Ray F. Schumacher, 999-W

Paul R. Burket, 773-42A

T. Bond Calloway, Jr., 999-W

\section{OCTOBER 2004}

Westinghouse Savannah River Company

Savannah River Site

Aiken, SC 29808

Prepared for the U.S. Department of Energy Under Contract Number DE-AC09-96SR18500

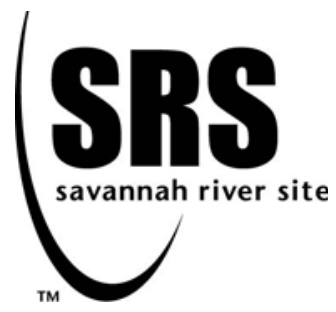


This page was intentionally left blank 


\section{TABLE OF CONTENTS}

LIST OF FIGURES ...........................................................................................................

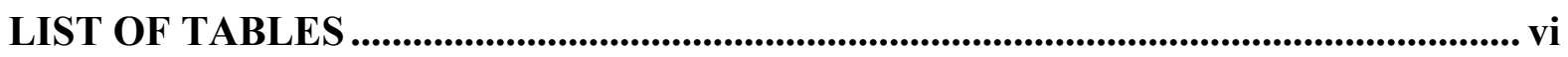

LIST OF ABBREVIATIONS AND ACRONYMS .......................................................... viii

LIST OF DEFINITIONS ......................................................................................................... ix

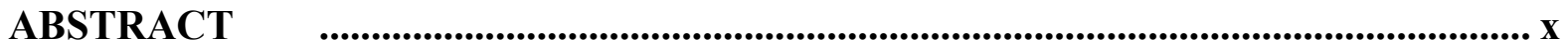

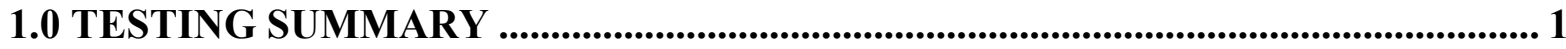

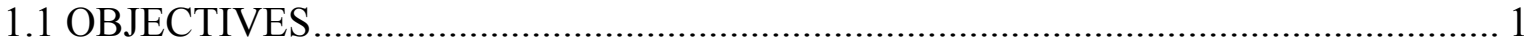

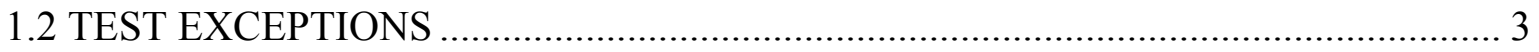

1.3 RESULTS AND PERFORMANCE AGAINST SUCCESS CRITERIA ……............... 3

1.3.1 Processability of Pretreated and Melter Feed........................................................ 5

1.3.1.1 LAW Vitrification Rheological Conditions..................................................... 5

1.3.1.2 LAW AN104SBS3565 Melter Feed Throughput Rates …………………........ 5

1.3.2 Measured Properties of the Pretreated Wastes........................................................ 6

1.3.3 Characterization Results of Melter Feed........................................................... 7

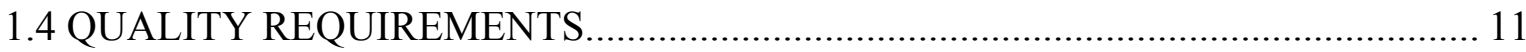

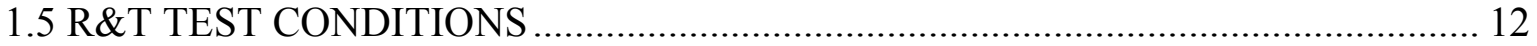

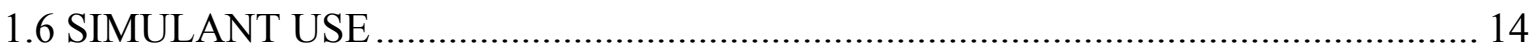

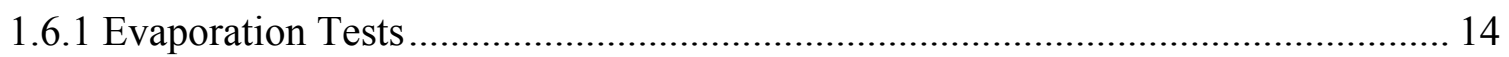

1.6.2 Rheology and Physical Properties Tests ......................................................... 15

1.6.3 Vitrification Tests.......................................................................................... 16

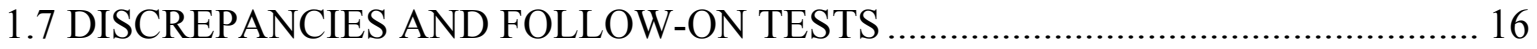

2.0 CD-ROM ENCLOSURES............................................................................................... 19

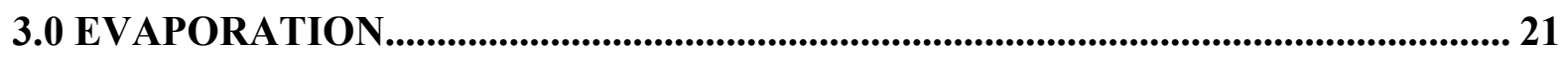

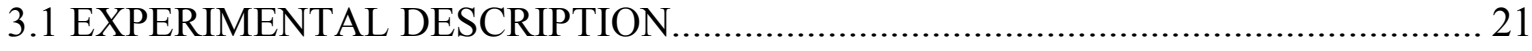

3.1.1 Blending AN-104 Pretreated Waste and SBS A3 Recycle ..................................... 21

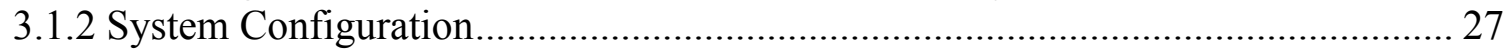

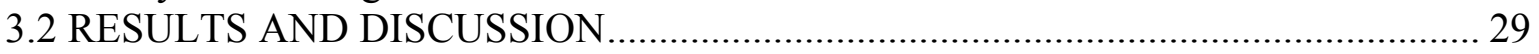

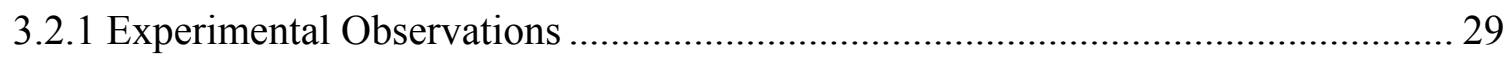

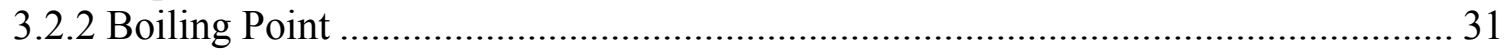

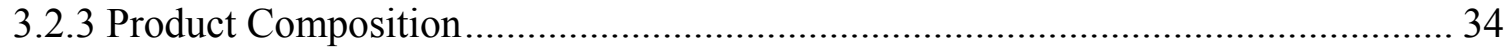

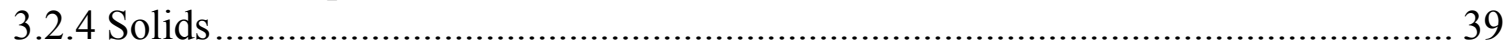

4.0 RHEOLOGY AND PHYSICAL PROPERTIES .............................................................. 41

4.1 CONDUCT OF TESTING ............................................................................... 41

4.2 GLASS FORMER CHEMICALS AND AN-104 BATCH SHEET ………………...... 42

4.3 LAW AN104SBS3565 SAMPLE PREPARATION ................................................. 44

4.3.1 LAW AN104SBS3565 Pretreated Waste................................................................ 44

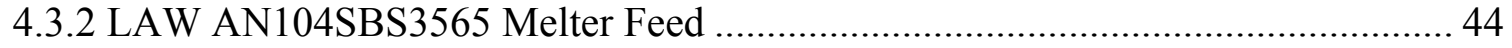

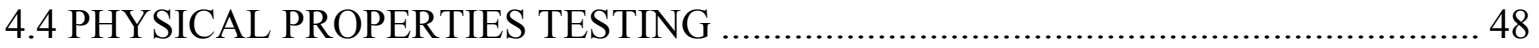

4.4.1 Methodology for Measuring Physical Properties.................................................... 49

4.4.1.1 General Method for Sample Prep and Analysis............................................... 49

4.4.1.2 LAW AN104SBS3565 Pretreated Waste Physical Properties ......................... 53

4.4.1.3 LAW AN104SBS3565 Melter Feed Physical Properties .................................. 53

4.4.2 Settling Results of LAW AN104SBS3565 Pretreated Wastes and Melter Feeds... 54 
WSRC-TR-2004-00232, REVISION 0

SRNL-RPP-2004-00044, REVISION 0

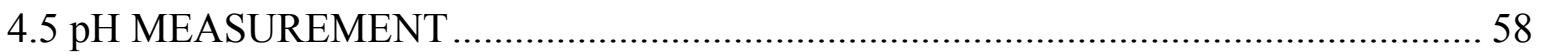

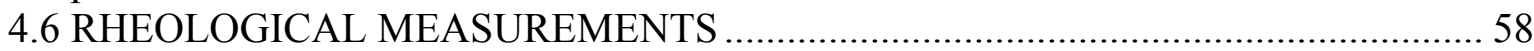

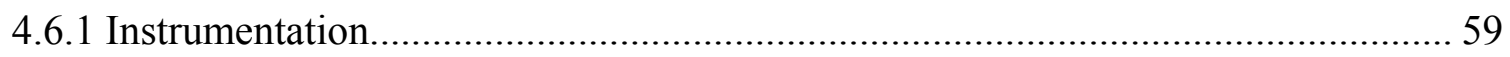

4.6.2 Flow Curve Measurements Using Concentric Geometry ................................... 59

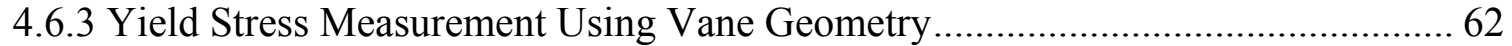

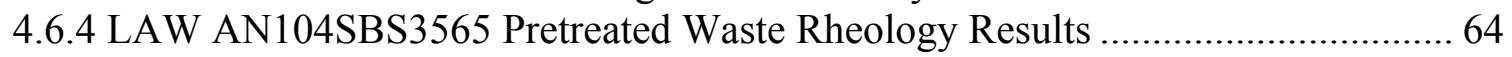

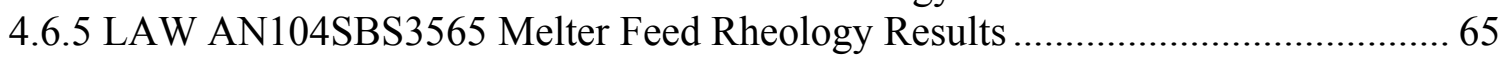

4.6.6 Settled Solids Vane Measurement Results.......................................................... 71

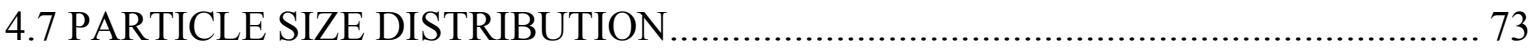

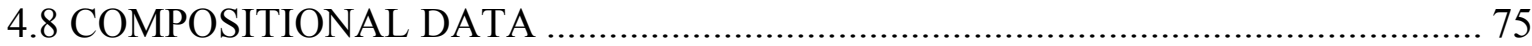

4.8.1 Glass Former Chemical Batch Makeup ............................................................ 75

4.8.2 LAW AN104SBS3565 Pretreated Waste Composition ...................................... 76

4.8.3 LAW AN104SBS3565 Melter Feed Composition............................................... 77

4.8.4 Calculating Processing Variable for AN104SBS3565 Melter Feed ....................... 78

5.0 CRUCIBLE-SCALE VITRIFICATION ............................................................ 81

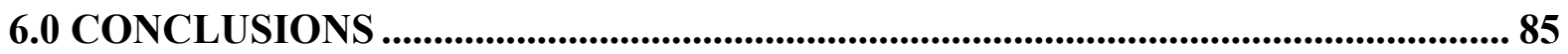

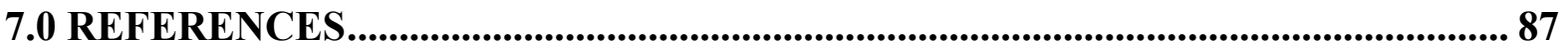

APPENDIX A. SOLIDS ANALYSES, PARTICLE SIZE DETERMINATION, AND BLEND RATIO DATA ....................................................................... 91

APPENDIX B. CORRECTING 7.29 M NA FEED STOCK AND BATCHING DILUTED FEED.......................................................................96

APPENDIX C. COMPOSITION OF GLASS FORMER CHEMICALS, MOISTURE CONTENT, AND BATCH CONTENTS ........................................... 103

APPENDIX D. FLOW CURVES ............................................................................. 106

APPENDIX E. PARTICLE SIZE DISTRIBUTION DATA ..................................... 116

APPENDIX F. WTP MEMO ON LAW CONTAINER CENTERLINE COOLING

DATA ............................................................................................ 129 
WSRC-TR-2004-00232, REVISION 0

SRNL-RPP-2004-00044, REVISION 0

\section{LIST OF FIGURES}

Figure 1-1. 6.0 M Na AN104SBS3565 and VSL AN-104 Melter Feed Flow Curves ......... 16

Figure 3-1. Settled and Mixed Solutions of Simulant SBS A3 Recycle.............................. 26

Figure 3-2. AN-104 Pretreated Waste and Settled AN104SBS3565 Pretreated Waste ....... 27

Figure 3-3. Evaporator Apparatus................................................................................. 28

Figure 3-4. Foaminess of 3.9 M Na AN104SBS3565 Pretreated Feed ............................. 31

Figure 3-5. OLI Treated Feed Evaporator Model ............................................................ 32

Figure 3-6. Experimental and Model Boiling Points for AN104SBS3565 Pretreated Waste

Figure 3-7. Experimental and Model Boiling Points for AN104SBS4555 Pretreated Waste

Figure 4-1. GFCs Added to Make 5.1 M Na AN104SBS3565 Melter Feed ....................... 47

Figure 4-2. GFCs Being Added and After Complete GFC Addition for 6.9 M Na

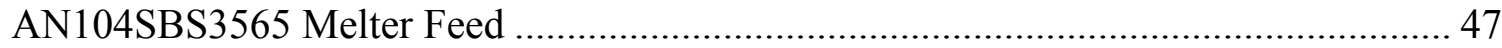

Figure 4-3. Settling of LAW AN104SBS3565 Pretreated Waste..................................... 55

Figure 4-4. Normalized Settling Curves for LAW AN104SBS3565 Pretreated Wastes...... 55

Figure 4-5. Normalized Settling Curves for LAW AN104SBS3565 Melter Feeds ............. 57

Figure 4-6. Vane Geometric Requirements .................................................................. 63

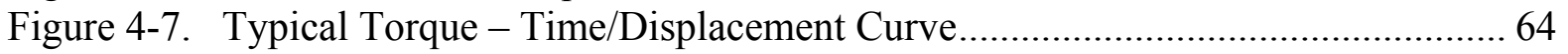

Figure 4-8. Vane Curves for LAW AN104SBS3565 Melter Feed Settled Solids................ 72

Figure 5-1. Temperature Profile vs. Time for AN104SBS3565 Crucible Glass Vitrification

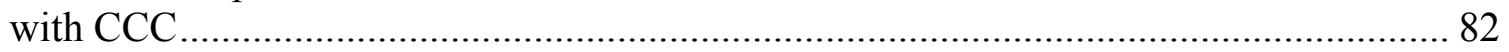

Figure 5-2. Bottom Surface of AN104SBS3565 Glass from Crucible Vitrification ........... 83

Figure 5-3. Top Surface of AN104SBS3565 Glass from Crucible Vitrification................. 83 


\section{LIST OF TABLES}

Table 1-1. Test Objectives for Evaporation, Rheology, and Vitrification ........................... 1

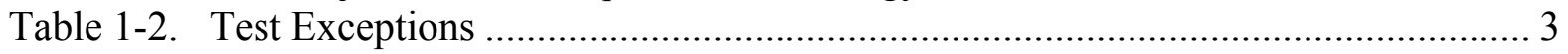

Table 1-3. Results and Performance Against Success Criteria............................................ 4

Table 1-4. LAW Vitrification Rheological Property Bounding Conditions .......................... 5

Table 1-5. Throughput Rates to Yield 30 and 60 MT of glass per day for AN104SBS3565 Melter Feeds

Table 1-6. Averaged Rheological Properties of LAW AN104SBS3565 Pretreated Wastes

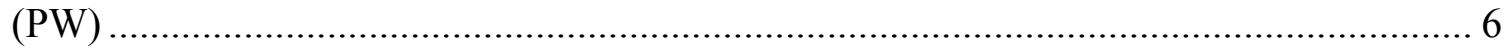

Table 1-7. Averaged Properties of LAW AN104SBS3565 Pretreated Wastes ..................... 7

Table 1-8. Properties of LAW AN104SBS3565 Melter Feed .............................................. 8

Table 1-9. Averaged Rheological Properties of LAW AN104SBS3565 Melter Feeds at

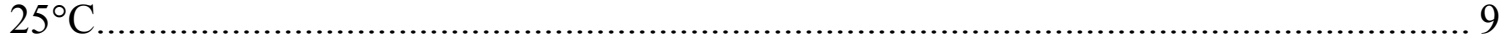

Table 1-10. Averaged Rheological Properties of LAW AN104SBS3565 Melter Feeds at

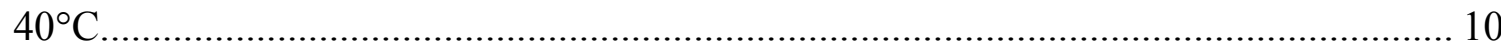

Table 1-11. Settled Solids Shear Strength of LAW AN104SBS3565 Melter Feed ............ 11

Table 1-12. R\& T Test Conditions for Evaporation, Rheology and Vitrification ................ 12

Table 1-13. Newtonian Results of 6.0 M Na AN104SBS3565 and VSL Melter Feeds...... 15

Table 1-14. Elemental and Oxide Composition of AN104SBS3565 and VSL Pretreated

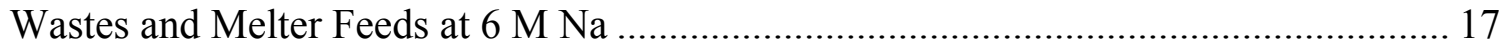

Table 3-1. Metals in the AN104 Pretreated Waste, SBS A3 Recycle and AN104SBS3565

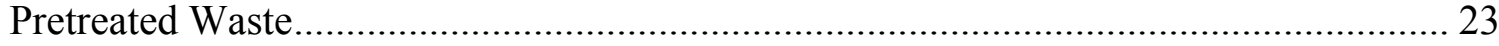

Table 3-2. Non-metals and Radionuclides in the AN104 Pretreated Waste, SBS A3 Recycle and AN104SBS3565 Pretreated Waste ....................................................................... 24

Table 3-3. Metals in the AN104 Pretreated Waste, SBS A3 Recycle and AN104SBS4555

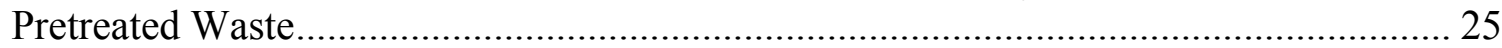

Table 3-4. Antifoam Performance at Different Conditions For AN104SBS Pretreated

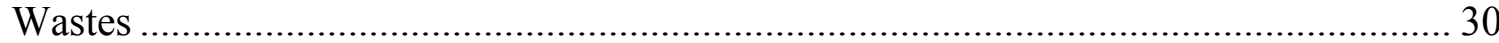

Table 3-5. Metals Products, CF and DF from Evaporation of AN104SBS3565 Pretreated

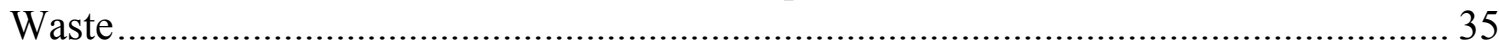

Table 3-6. Anions and Other Evaporation Products of the AN104SBS3565 Pretreated Waste .

Table 3-7. Comparison of AN104SBS3565 Pretreated Waste Evaporator Solutions by

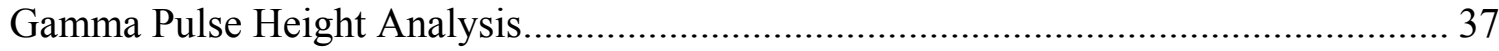

Table 3-8. Metal Products of Starting and Final AN104SBS4555 Pretreated Waste.......... 38

Table 3-9. Major Cations in the Undissolved Solids for the SBS A3 Recycle and

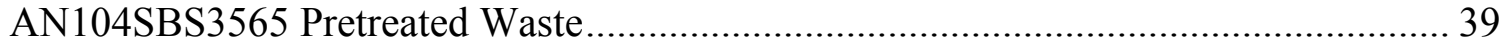

Table 4-1. Glass Former Chemicals Utilized................................................................. 42

Table 4-2. VSL GFC Batch Sheet LAWB98 for SRNL LAW AN104SBS3565 Pre-Treated

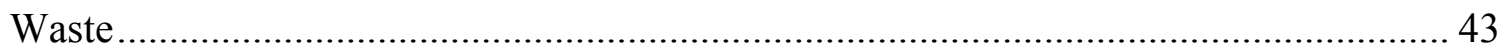

Table 4-3. Mass of Blended GFCs Used For the Various Pretreated Wastes..................... 45

Table 4-4. Description of Mixing Tanks and Agitators Used To Make Melter Feed.......... 46

Table 4-5. Agitator Speeds during GFCs Addition and Extended Mixing........................ 48

Table 4-6. Solids Analysis of LAW AN104SBS3565 Pretreated Wastes .......................... 53

Table 4-7. Solids Analysis of LAW AN104SBS3565 Melter Feeds................................. 54 
Table 4-8. Normalized Interface Volume for LAW AN104SBS3565 Pretreated Wastes.... 56

Table 4-9. Normalized Interface Volume for LAW AN104SBS3565 Melter Feed ............. 57

Table 4-10. pH of LAW AN104SBS3565 Melter Feeds .................................................... 58

Table 4-11. Haake M5 Measuring Head Specifications .................................................. 59

Table 4-12. MV1 Rotor Specifications and Ramp Rates............................................... 60

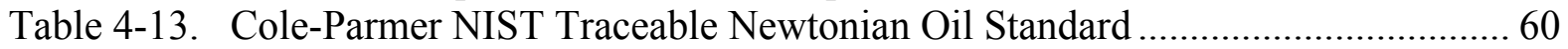

Table 4-14. M5/MV1 Operability Checks Using NIST Traceable Viscosity Oil Standards 61

Table 4-15. LAW AN104SBS3565 Rheology - Newtonian Results ................................. 65

Table 4-16. LAW AN104SBS3565 Melter Feed Flow Curves Fitted as a Newtonian Fluid66

Table 4-17. Rheological Results of LAW AN104SBS3565 (Pretreated Waste at 5.1 M Na)

Melter Feed at $25^{\circ} \mathrm{C}$ and $40^{\circ} \mathrm{C}$ After 1 Day of Mixing. 67

Table 4-18. Rheological Results of LAW AN104SBS3565 (Pretreated Waste at $6.0 \mathrm{M} \mathrm{Na}$ )

Melter Feed at $25^{\circ} \mathrm{C}$ and $40^{\circ} \mathrm{C}$ After 1 Day of Mixing. 68

Table 4-19. Rheological Results of LAW AN104SBS3565 (Pretreated Waste at 6.0 M Na)

Melter Feed at $25^{\circ} \mathrm{C}$ and $40^{\circ} \mathrm{C}$ After 7 Days of Mixing

Table 4-20. Rheological Results of LAW AN104SBS3565 (Pretreated Waste at 6.9 M Na)

Melter Feed at $25^{\circ} \mathrm{C}$ and $40^{\circ} \mathrm{C}$ After 1 Day of Mixing.... 70

Table 4-21. Summary of Particle Size Data for Standards ............................................. 74

Table 4-22. Summary of Particle Size Distribution Data for AN104SBS3565 Pretreated

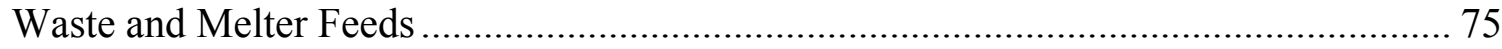

Table 4-23. Oxide and Elemental Composition of Blended LAWA137 Batch.................. 76

Table 4-24. Elemental Composition of LAW AN104SBS3565 Pretreated Wastes ............. 77

Table 4-25. Elemental Composition of AN104SBS3565 Melter Feeds ............................. 78

Table 5-1. Estimated Radionuclides in AN-104 Glass ................................................... 84 
WSRC-TR-2004-00232, REVISION 0

SRNL-RPP-2004-00044, REVISION 0

\section{LIST OF ABBREVIATIONS AND ACRONYMS}

\begin{tabular}{|c|c|}
\hline AA & Atomic Absorption \\
\hline AN104SBS & Blend of $4.74 \mathrm{M}$ Na radioactive AN-104 pretreated waste and $0.097 \mathrm{M} \mathrm{Na}$ SBS A3 recycle \\
\hline AN104SBS3565 & $\begin{array}{l}\text { Blend containing } 35 \text { volume percent of } 4.74 \mathrm{M} \mathrm{Na} \text { radioactive AN-104 pretreated waste to } 65 \\
\text { percent } 0.097 \mathrm{M} \text { Na SBS A3 recycle }\end{array}$ \\
\hline AN104SBS4555 & $\begin{array}{l}\text { Blend containing } 45 \text { volume percent } 4.74 \mathrm{M} \mathrm{Na} \text { radioactive } \mathrm{AN}-104 \text { pretreated waste to } 55 \text { percent } \\
0.097 \mathrm{M} \mathrm{Na} \text { SBS A3 recycle }\end{array}$ \\
\hline $\mathrm{BP}$ & Bingham Plastic \\
\hline CCC & Canister Centerline Cooling \\
\hline $\mathrm{CF}$ & Concentration Factor \\
\hline $\mathrm{CRV}$ & Concentrate Receipt Vessel \\
\hline DCP-AES & Direct Current Plasma Atomic Emission Spectroscopy \\
\hline DF & Decontamination Factor \\
\hline DI & Deionized \\
\hline DOE & Department of Energy \\
\hline GFC & Glass Former Chemical \\
\hline HB & Hershel Bulkley \\
\hline HPLC & High Performance Liquid Chromatography \\
\hline IC & Ion Chromatography \\
\hline ICPES & Inductivity Coupled Plasma - Emission Spectroscopy \\
\hline ILAW & Immobilized Low Activity Waste \\
\hline ILAW QD & Immobilized Low Activity Waste Qualification Documentation \\
\hline ITS & Immobilization Technology Section \\
\hline IX & Ion Exchange \\
\hline LAW & Low Activity Waste \\
\hline M\&TE & Measuring and Test Equipment \\
\hline MFPV & Melter Feed Preparation Vessel \\
\hline MFV & Melter Feed Vessel \\
\hline MT & Metric Ton \\
\hline NAS & Sodium Aluminosilicate \\
\hline NIST & National Institute of Standards and Technology \\
\hline NM & Not Measured \\
\hline OLI & OLI Systems \\
\hline OLI/ESP & OLI Environmental Simulation Program \\
\hline PA & Performance Assessment \\
\hline PCT & Product Consistency Test \\
\hline PSD & Particle Size Distribution \\
\hline $\mathrm{PW}$ & Pretreated Waste \\
\hline QA & Quality Assurance \\
\hline RPM & Revolutions Per Minute \\
\hline RPP-WTP & River Protection Project - Waste Treatment Plant \\
\hline SBS & Submerged Bed Scrubber \\
\hline SD & Standard Deviation \\
\hline SEM & Scanning Electron Microscopy \\
\hline SRNL & Savannah River National Laboratory \\
\hline SRTC & Savannah River Technology Center \\
\hline SRTC QA & Savannah River Technology Center Quality Assurance \\
\hline TIC/TOC & Total Inorganic Carbon and Total Organic Carbon Analysis \\
\hline TRU & Transuranic \\
\hline TTP & Technical Task Plan \\
\hline UDS & Undissolved Solids \\
\hline VSL & Vitreous State Laboratories \\
\hline WSRC & Westinghouse Savannah River Company \\
\hline XRD & X-ray Diffraction \\
\hline $\mathrm{XRF}$ & X-Ray Fluorescence \\
\hline
\end{tabular}


WSRC-TR-2004-00232, REVISION 0

SRNL-RPP-2004-00044, REVISION 0

\section{LIST OF DEFINITIONS}

\begin{tabular}{|c|c|}
\hline Variable & Definition \\
\hline Apparent viscosity & The measured shear stress divided by the measured shear rate. \\
\hline Density & Mass per unit volume. \\
\hline Flow curve/rheogram & Plot of shear stress versus shear rate. \\
\hline Interstitial solution & Solution contained between suspended, settled, or centrifuged solids. \\
\hline Newtonian Fluid & A fluid whose apparent viscosity is independent of shear rate. \\
\hline Non-Newtonian Fluid & A fluid whose apparent viscosity varies with shear rate. \\
\hline $\begin{array}{l}\text { Settled solids shear } \\
\text { strength }\end{array}$ & $\begin{array}{l}\text { The maximum shear stress as determined by the vane method for a slurry } \\
\text { sample that is allowed to settle for a specified amount of time. }\end{array}$ \\
\hline Solution & A liquid phase that can contain soluble solids. \\
\hline Slurry & A mixture of insoluble solids and solution \\
\hline Supernatant Liquid & $\begin{array}{l}\text { A liquid phase overlying material deposited by settling, precipitation, or } \\
\text { centrifugation. }\end{array}$ \\
\hline Solids Settling Rate & $\begin{array}{l}\text { Rate at which solids in a homogenized sample settle. The change in the } \\
\text { interface height between the supernate and settled solids as a function of time. }\end{array}$ \\
\hline vol $\%$ centrifuged solids & $\begin{array}{l}\text { The volume of the solids layer that separates from the bulk slurry after } 1 \text { hour } \\
\text { of centrifugation at } 1000 \text { gravities divided by the total sample volume on a } \\
\text { percentage basis. These centrifuged solids will contain interstitial solution. }\end{array}$ \\
\hline vol $\%$ settled solids & $\begin{array}{l}\text { The percentage of the volume of the slurry sample that the settled solids } \\
\text { occupy after settling for } 72 \text { hours under one gravity. These settled solids will } \\
\text { contain interstitial solution. }\end{array}$ \\
\hline $\mathrm{wt} \%$ centrifuged solids & $\begin{array}{l}\text { The mass of the solids layer that separates from the bulk slurry after } 1 \text { hour of } \\
\text { centrifugation at } 1000 \text { gravities divided by the total bulk slurry sample mass on } \\
\text { a percentage basis. These centrifuged solids will contain interstitial solution. }\end{array}$ \\
\hline $\mathrm{wt} \%$ oven dried solids & $\begin{array}{l}\text { The percent mass of the centrifuged solids remaining after removing volatiles } \\
\text { including free water by drying at } 105 \pm 5^{\circ} \mathrm{C} \text { for } 24 \text { hours. }\end{array}$ \\
\hline $\mathrm{wt} \%$ settled solids & $\begin{array}{l}\text { The percentage (mass basis) of settled solids present in the sample. Calculated } \\
\text { on a percentage basis by dividing the mass of the settled solids by the mass of } \\
\text { sample. }\end{array}$ \\
\hline $\begin{array}{l}\text { wt } \% \text { soluble solids in } \\
\text { supernatant }\end{array}$ & $\begin{array}{l}\text { Calculated on a percentage basis by dividing the mass of the dried supernatant } \\
\text { by the mass of the supernatant prior to drying. }\end{array}$ \\
\hline $\mathrm{wt} \%$ total oxides & $\begin{array}{l}\text { The percentage of the mass of the bulk sample that remains after converting all } \\
\text { non-volatile elements to oxides. Dried slurry calcined at } 1050^{\circ} \mathrm{C} \pm 50^{\circ} \mathrm{C} \text { for } 1 \\
\text { hour. }\end{array}$ \\
\hline $\mathrm{wt} \%$ total solids & The percentage of the mass of dried solids divided by the mass of the slurry. \\
\hline $\mathrm{wt} \%$ undissolved solids & $\begin{array}{l}\text { Calculated on a percentage basis by dividing the calculated mass of the } \\
\text { undissolved solids by the mass of the bulk solids. }\end{array}$ \\
\hline Yield Stress & $\begin{array}{l}\text { The minimum stress required to initiate flow. Determined by fitting measured } \\
\text { flow curve using non-Newtonian rheological models. }\end{array}$ \\
\hline
\end{tabular}




\title{
WSRC-TR-2004-00232, REVISION 0 SRNL-RPP-2004-00044, REVISION 0
}

\begin{abstract}
A 4.74 M Na LAW AN104 pretreated waste was blended with $0.097 \mathrm{M}$ Na SBS A3 recycle simulant at volumetric ratios of $35 \%$ AN104 to $65 \%$ SBS and $45 \%$ AN104 to 55\% SBS. Evaporation tests on the radioactive blends indicate minimal precipitation of solids in the nominal sodium concentrate range of 5 to $8 \mathrm{M}$. No formation of potentially troublesome solids leading to solids-coating or sticking was observed and no sodium aluminosilicate (NAS) solids were observed from the AN104SBS concentrated pretreated wastes. Boiling points were determined to be linear over the temperature range of 48 to $56^{\circ} \mathrm{C}$ in the pressure range of 60 to $80 \mathrm{~mm} \mathrm{Hg}$. The AN104SBS pretreated wastes foamed during evaporation, and foam height increased almost linearly with flux. Nominally 400 to $900 \mathrm{mg} / \mathrm{L}$ of antifoam (Dow Q2-3138a) was effective at decreasing foam from over 100\% of liquid height to 20 to $40 \%$ or no visible foam. Decontamination factors for the small-scale evaporator were measured to be greater than 15,000 for aluminum and 80,000 for sodium.
\end{abstract}

Physical (including rheological) property measurements were obtained on the AN104SBS3565 pretreated waste in the range of 4.7 to $6.3 \mathrm{M}$ sodium. Physical (including rheological) properties were also measured on the AN104SBS3565 melter feeds at 5.1, 6.0 and 6.9 M sodium (Na molarities are those of the pretreated waste) after 1 day of mixing. The $6.0 \mathrm{M} \mathrm{Na}$ melter feed properties were also measured after 7 days of mixing. Review of the 5.1 and $6.0 \mathrm{M} \mathrm{Na}$ melter feed flow curves at the maximum hold shear rate of $1000 \mathrm{sec}^{-1}$ showed no thixotropic behavior, and these slurries are all Newtonian in nature. The viscosities of the pretreated wastes were in the range of 0.003 to $0.005 \mathrm{~Pa}-$ sec, and the viscosities of the melter feeds were in the range of 0.02 to $0.3 \mathrm{~Pa}$-sec. Settled solids shear strengths were also measured after 48 hours of settling for all of the melter feeds. The settled solids shear strengths of the 5.1 and $6.0 \mathrm{M} \mathrm{Na}$ melter feeds were in the range of 8 to $16 \mathrm{~Pa}$, and the settled solids shear strength for the 6.9 $\mathrm{M} \mathrm{Na}$ melter feed was higher at $48 \mathrm{~Pa}$.

Rheological results have been compared to LAW vitrification rheological property bounding conditions for the CRV, MFPV and MFV processes. The viscosities of the pretreated wastes are all within the CRV rheological bounding conditions. The LAW 6.9 M Na AN104SBS3565 melter feed Bingham Plastic consistency exceeded the MFPV/MFV maximum consistency limit. The Bingham Plastic yield stress, for the $6.9 \mathrm{M} \mathrm{Na}$ melter feed data fitted to the up curves, exceeded the MFPV/MFV maximum yield stress limit. The settled solids shear strengths were within the bounding condition. The Hedstrom numbers were also within the bounding condition. Of the fluids characterized, only the $6.9 \mathrm{M} \mathrm{Na}$ melter feed exceeded the bounding rheological conditions of the vitrification facility.

A 55-g glass AN104SBS3565 monolith was produced in a 600-mL Pt crucible with WTP-approved canister centerline cooling curve using the LA137SRCCC formulation. This glass formulation was developed by VSL using the characterization data obtained at SRNL for the radioactive 4.74 $\mathrm{M} \mathrm{Na}$ AN104SBS3565 pretreated waste analyses. The radioactive product glass appeared to be dark brown in color and a homogeneous glass that is similar to the simulant glass made by VSL in glass formulation development work. Estimated radionuclide concentrations in the glass indicate that for Tc-99, Sr-90 and Cs-137, the concentration of these radionuclides were well below the WTP contract upper limits for LAW glass. 


\subsection{TESTING SUMMARY}

\subsection{OBJECTIVES}

The test objectives for this scope of work are listed in Table 1-1. This study involved evaporation of the radioactive low activity waste (LAW) AN-104 pretreated waste and a simulant LAW submerged bed scrubber (SBS) recycle from Duratek blended at two different volume ratios. The AN104SBS3565 ${ }^{1}$ pretreated wastes were then blended with glass former chemicals (GFCs) and a single blend vitrified. The chemical and physical properties, during all phases of blending were characterized per Table 1-1. The AN-104 radioactive waste used for this study was initially characterized at SRNL (Hay 2003), followed by filtration to remove entrained solids (Poirier 2003), and put through ion exchange for cesium removal (Adu-Wusu 2003). All the test objectives in Table 1-1 are from section 3 of the Test Specification (Sidibe 2003). The test exception listed in Table 1-2 deleted the vitrification objectives for vitrification product analyses and product testing of the AN-104 glass. Therefore, Table 1-1 does not list any vitrification product analyses and product testing objectives.

Table 1-1. Test Objectives for Evaporation, Rheology, and Vitrification

\begin{tabular}{|c|c|c|}
\hline Test Objectives & $\begin{array}{l}\text { Objective } \\
\text { Met }(\mathbf{Y} / \mathbf{N})\end{array}$ & Discussion \\
\hline $\begin{array}{l}\text { Determine effects of plant recycle on } \\
\text { evaporation process. }\end{array}$ & Y & $\begin{array}{l}\text { Precipitation of solids was minimal in the sodium } \\
\text { concentration range expected. No problematic solids were } \\
\text { observed as discussed in Section 3.2.4. Therefore, recycles } \\
\text { are not expected to create problems during the evaporation } \\
\text { of LAW AN-104 pretreated waste. }\end{array}$ \\
\hline $\begin{array}{l}\text { Develop solubility data for evaporator } \\
\text { concentrate solution. }\end{array}$ & $\mathrm{Y}$ & $\begin{array}{l}\text { Soluble species were characterized at two different sodium } \\
\text { concentrations for the AN104SBS3565 pretreated waste } \\
\text { and are discussed in Section 3.2.3. Soluble species were } \\
\text { also characterized for a single sodium concentration for the } \\
\text { AN104SBS } 4555^{2} \text { pretreated waste and is discussed in } \\
\text { Section 3.2.3. It should be noted that initial objectives } \\
\text { specified in the Test Specification for evaporator (pretreated } \\
\text { waste) concentration endpoints were given as nominally } 6 \text {, } \\
8 \text { and } 10 \text { molar sodium. However, as the TTP evolved and } \\
\text { melter studies were performed at VSL (Matlock 2003) and } \\
\text { GTS Duratek (Duratek 2003), the concentration endpoint } \\
\text { for the evaporator concentrate was targeted per WTP } \\
\text { direction at } 6 \mathrm{M} \text { Na with the upper and lower targets set at } \\
\pm 15 \% \text { of the } 6 \mathrm{M} \text { Na target. This lower sodium } \\
\text { concentration is captured in a Test Exception as described } \\
\text { in section 1.2. }\end{array}$ \\
\hline
\end{tabular}

\footnotetext{
${ }^{1}$ AN104SBS3565 = Original blend containing 35 volume percent of $4.7 \mathrm{M}$ Na radioactive AN-104 pretreated waste to 65 percent $0.097 \mathrm{M}$ Na SBS A3 recycle.

${ }^{2}$ AN104SBS4555 = Original blend containing 45 volume percent of $4.7 \mathrm{M}$ Na radioactive AN-104 pretreated waste to 55 percent $0.097 \mathrm{M} \mathrm{Na}$ SBS A3 recycle.
} 
WSRC-TR-2004-00232, REVISION 0
SRNL-RPP-2004-00044, REVISION 0

Table 1-1. Test Objectives for Evaporation, Rheology, and Vitrification

\begin{tabular}{|c|c|c|}
\hline Test Objectives & $\begin{array}{l}\text { Objective } \\
\text { Met (Y/N) } \\
\end{array}$ & Discussion \\
\hline $\begin{array}{l}\text { Develop chemical and physical } \\
\text { property data for various evaporator } \\
\text { solutions as a function of concentration } \\
\text { and temperature. }\end{array}$ & $\mathrm{Y}$ & $\begin{array}{l}\text { Chemical analyses were performed on the initial AN-104 } \\
\text { pretreated waste, condensate and AN104SBS } \\
\text { wastes at several sodium concentrations and is discussed in } \\
\text { Section 3.2.3. In addition, the boiling points in the } \\
\text { temperature range of } 48 \text { to } 56^{\circ} \mathrm{C} \text { of the evaporator } \\
\text { concentrates across a range of pressures of } 60 \text { to } 80 \mathrm{~mm} \mathrm{Hg} \\
\text { were measured for the AN104SBS pretreated wastes at } \\
\text { different sodium concentrations and are discussed in } \\
\text { Section 3.2.2. }\end{array}$ \\
\hline $\begin{array}{l}\text { Evaluate effectiveness of antifoam } \\
\text { reagent on actual waste blended with } \\
\text { recycle under WTP conditions. }\end{array}$ & $\mathrm{Y}$ & $\begin{array}{l}\text { Nominally } 400 \text { to } 900 \mathrm{ppm}(\mathrm{mg} / \mathrm{L} \text { ) of antifoam (Dow Q2- } \\
3138 \mathrm{a} \text { ) was effective at minimizing foam from over } 100 \% \\
\text { of liquid height to } 20 \text { to } 40 \% \text { of liquid height or no visible } \\
\text { foam as discussed in Section 3.2.1. }\end{array}$ \\
\hline $\begin{array}{l}\text { Obtain measurements of solids } \\
\text { concentrations, particle size } \\
\text { distribution, densities, and rheological } \\
\text { properties of the AN-104 LAW } \\
\text { pretreated waste and LAW melter } \\
\text { feed. }\end{array}$ & $\mathrm{Y}$ & $\begin{array}{l}\text { Physical properties and } \mathrm{pH} \text { were obtained for } \\
\text { AN104SBS3565 pretreated waste at sodium concentrations } \\
\text { between } 4.7 \text { and } 6.3 \mathrm{M} \mathrm{Na} \text { (see Sections } 4.4 \text { to } 4.6 \text { ), and } \\
\text { melter feed at three different sodium molarities of } 5.1 \text { and } 6 \\
\text { and } 6.9 \text { (see Sections } 3.1 \text { to } 3.2 \text { and } 4.4 \text { to } 4.6 \text { ). }\end{array}$ \\
\hline $\begin{array}{l}\text { Generate a glass product for } \\
\text { subsequent product testing. }\end{array}$ & $\mathrm{Y}$ & $\begin{array}{l}\text { AN-104 LAW crucible vitrification was completed to } \\
\text { produce a glass per the specified RPP-WTP/VSL glass } \\
\text { forming recipe (See Section 5.0). }\end{array}$ \\
\hline
\end{tabular}

${ }^{3} \mathrm{AN} 104 \mathrm{SBS}=$ Blend of 4.7 M Na radioactive AN-104 pretreated waste blended with 0.097M Na SBS A3 recycle 
WSRC-TR-2004-00232, REVISION 0

SRNL-RPP-2004-00044, REVISION 0

\subsection{TEST EXCEPTIONS}

Two different Test Exceptions were issued during this task. The descriptions of the test exceptions are shown in Table 1-2.

Table 1-2. Test Exceptions

\begin{tabular}{|l|l|}
\hline List Test Exception & Describe Test Exception \\
\hline 1. Test Exception Number: 24590-WTP-TEF-RT- & $\begin{array}{l}\text { This Test Exception removed the work scope associated } \\
\text { with the Vitrification product testing of the AN-104 glass. } \\
\text { Specifically, the following work scope related to } \\
\text { Vitrification testing of AN-104 actual waste glass samples } \\
\text { was removed: Glass analysis for elemental composition; } \\
\text { Glass analysis for anion composition; Glass analysis for } \\
\text { radionuclide composition; Glass analysis for the presence } \\
\text { of crystalline/non-crystalline phases; Product Consistency } \\
\text { Test; Vapor Hydration Test. }\end{array}$ \\
\hline 2. Test Exception Number: 24590-LAW-TEF-RT- & $\begin{array}{l}\text { This Test Exception decreased the sodium concentration in } \\
\text { the Evaporation Testing concentrate from } 8 \text { M to a target } \\
\text { concentration of } 6 \text { M. Solubility testing above the target } 6 \\
\text { M Na pretreated waste, and flow curves of the 5.1 and } 6.9 \\
\text { M Na pretreated waste at 40 } 40^{\circ} \text { C were removed. Physical } \\
\text { and rheological properties of the concentrated pretreated } \\
\text { waste and associated melter feed at target concentrations } \\
\text { of 5.1, } 6.0 \text { and } 6.9 \text { M Na (based on pretreated waste) were } \\
\text { to be performed per the Test Specification. } \\
\text { Measurement of radiochemical activity in the LAW } \\
\text { pretreated waste, LAW pretreated waste/SBS solution and } \\
\text { condensate were limited to gamma energy analysis (GEA). } \\
\text { Heat capacity measurements on the AN-104 LAW } \\
\text { pretreated waste/SBS solutions were deleted. }\end{array}$ \\
\hline
\end{tabular}

\subsection{RESULTS AND PERFORMANCE AGAINST SUCCESS CRITERIA}

The success criteria as listed in the Test Specification and Technical Task Plan (Crawford 2003) are listed in Table 1-3. A summary of the processability of the evaporated AN104SBS pretreated wastes and the melter feeds are in Section 1.3.1. Summary characterization results for physical properties and $\mathrm{pH}$ of the AN104SBS3565 pretreated wastes are in section 1.3.2. For the AN104SBS3565 melter feeds, the summary characterization results for the physical properties and $\mathrm{pH}$ are in section 1.3.3. 
WSRC-TR-2004-00232, REVISION 0 SRNL-RPP-2004-00044, REVISION 0

Table 1-3. Results and Performance Against Success Criteria

Explain How the Tests Did or Did Not Meet the Success Criteria

\section{Evaporation Scope}

TS, Section $4,1^{\text {st }}$ paragraph \& TTP, Section II. Evaporation of pretreated AN-104, Envelope A waste mixed with LAW SBS recycle simulant without formation of solids which may coat the evaporator vessel or constrict the reboiler and pipelines.

TS, Section $4,1^{\text {st }}$ paragraph \& TTP, Section II. Results of this testing will be compared against G-2 Model Runs for AN-104.
No formation of potentially troublesome solids observed during evaporation of the pretreated waste mixed with recycle (See Section 3.2.4).

OLI modeling was conducted for this AN-104 task and the data from this task was compared against the model (See Section 3.2.2) for the sodium concentration range of $5-8$ $\mathrm{M}$ and the pressure range of 60 to $80 \mathrm{~mm} \mathrm{Hg}$.

Experimental boiling points were 2 to $4{ }^{\circ} \mathrm{C}$ higher than model predictions. The slopes of boiling points vs. pressure were similar between the experimental and model data. The original intent of the WTP evaporator R\&T task was to develop OLI models of the evaporator process and compare those with experimental results. OLI modeling was conducted for this task (See Modeling Treated Feed Evaporation (Daniel 2003) and Treated LAW Feed Evaporation: Physical Properties and Solubility (Josephs 2003)). Thus, the OLI models developed by SRNL were used for this task.

TS, Section $4,1^{\text {st }}$ paragraph \& TTP, Section II. Chemical and physical property data at equivalent conditions to those tested with simulants will be developed.

TS, Section $4,1^{\text {st }}$ paragraph \& TTP, Section II. Antifoam performance is to be assessed as a percentage of volume of the liquid phase.
A 6.0 M Na AN104SBS3565 pretreated waste and melter VSL. This comparison was performed in section 1.6, indicating a good agreement between the simulant and actual waste.

Antifoam performance was assessed as a percentage of volume of liquid phase. The range of antifoam testing was from 0 to $910 \mathrm{mg} / \mathrm{L}$ as detailed in Section 3.2.1. feed was compared to a simulant AN104 developed by

\section{Physical Rheological Properties Scope}

TS, Section $4,1^{\text {st }}$ paragraph \& TTP, Section II. Rheological properties of the resulting evaporated solutions will be such that they will meet the criteria for processing through the LAW Vitrification system.

TS, Section $4,1^{\text {st }}$ bullet item \& TTP, Section II. The rheological measurements demonstrate that the slurries can be transferred at solids concentrations that will meet melter throughput requirements.
Rheological properties of the resulting evaporated pretreated wastes shown in Summary Table 1-7 were all within the rheological limits (See Summary Table 1-4) for processing the pretreated feeds through the LAW Vitrification system

Rheological measurements were conducted on pretreated wastes and melter feed slurries per WTP guidance. The 5.1 $\mathrm{M}$ and 6.0 $\mathrm{M} \mathrm{Na}$ melter feeds are within the rheological bounds of the LAW Vitrification system and the 6.9 M Na melter feed was outside the bound (See Summary Table 1-8 vs. the LAW Vitrification Rheological Property Bounding Conditions Table 1-4) The rates required to process 30 and $60 \mathrm{MT}$ of glass per day for the 5.1 $\mathrm{M}$ and 6.0 M Na melter feeds are stated in Section 1.3.1.2. 


\subsubsection{Processability of Pretreated and Melter Feed}

\subsubsection{LAW Vitrification Rheological Conditions}

The LAW vitrification rheological property bounding conditions for the concentrate receipt vessel (CRV), melter feed preparation vessel (MFPV) and melter feed vessel (MFV) are provided in (Poloski 2004) and are summarized in Table 1-4. The rheological properties of the pretreated wastes are presented in Table 1-6 and are all within the CRV rheological bounding conditions.

Table 1-4. LAW Vitrification Rheological Property Bounding Conditions

\begin{tabular}{|c|c|c|}
\hline Process & Category & Value \\
\hline CRV & Minimum Viscosity & $0.9 \mathrm{mPa} \cdot \mathrm{s}$ \\
\hline CRV & Maximum Viscosity & $15 \mathrm{mPa} \cdot \mathrm{s}$ \\
\hline MFPV/MFV & Minimum Consistency & $0.9 \mathrm{mPa} \cdot \mathrm{s}$ \\
\hline MFPV/MFV & Maximum Consistency & $90 \mathrm{mPa} \cdot \mathrm{s}$ \\
\hline MFPV/MFV & Minimum Yield Stress & $0 \mathrm{~Pa}$ \\
\hline MFPV/MFV & Maximum Yield Stress & $15 \mathrm{~Pa}$ \\
\hline MFPV/MFV & Maximum Settled Solids Shear Strength & $625 \mathrm{~Pa}$ \\
\hline MFPV/MFV & Maximum Hedstrom Number in 2" pipe & $10^{8}$ \\
\hline
\end{tabular}

The rheological properties for the melter feeds are listed in Table 1-9, Table 1-10 and Table 1-11. The 6.9 M Na AN104SBS3565 melter feed exceeded the MFPV/MFV maximum consistency limit and at times the maximum yield stress (Bingham Plastic). The settled solids shear strength reported in Table 1-11 were within the bounding condition. Values for the Hedstrom number (see section 4.8.4), shown in Table 1-9 and Table 1-10 are also within the bounding condition. Of the fluids characterized, only the 6.9 M Na AN104SBS3565 melter feed can not be processed in the vitrification facility based on the bounding conditions provided in Table 1-4.

\subsubsection{LAW AN104SBS3565 Melter Feed Throughput Rates}

The throughput requirements (mass and volumetric feed rates) are shown in Table 1-5 for processing 30 or 60 metric tons (MT) of glass per day. The table contains data for the $5.1 \mathrm{M}$ and 6.0 M Na AN104SBS3565 melter feeds. The 6.9 M Na AN104SBS3565 melter feed throughput was not determined, since it was rheologically outside the rheological bounding conditions. Section 4.8.4 provides the method used for calculating throughput rates. 
WSRC-TR-2004-00232, REVISION 0

SRNL-RPP-2004-00044, REVISION 0

Table 1-5. Throughput Rates to Yield 30 and 60 MT of glass per day for AN104SBS3565 Melter Feeds

\begin{tabular}{|c|c|c|c|c|}
\hline \multirow{3}{*}{$\begin{array}{l}\text { AN104SBS3565 } \\
\text { Melter Feed* } \\
\text { Feed }\end{array}$} & \multicolumn{4}{|c|}{ Glass production rates } \\
\hline & \multicolumn{2}{|c|}{$30 \mathrm{MT} /$ day } & \multicolumn{2}{|c|}{$60 \mathrm{MT} /$ day } \\
\hline & $\begin{array}{c}\text { Mass rate } \\
(\mathrm{kg} / \mathrm{min})\end{array}$ & $\begin{array}{l}\text { Volumetric rate } \\
\text { (Liters/min) }\end{array}$ & $\begin{array}{c}\text { Mass rate } \\
(\mathrm{kg} / \mathrm{min})\end{array}$ & $\begin{array}{l}\text { Volumetric rate } \\
\text { (Liters/min) }\end{array}$ \\
\hline $5.1 \mathrm{M} \mathrm{Na}$ & 86.5 & 53.4 & 173.0 & 106.8 \\
\hline $6.0 \mathrm{M} \mathrm{Na}$ & 80.9 & 47.6 & 161.9 & 95.2 \\
\hline
\end{tabular}

\subsubsection{Measured Properties of the Pretreated Wastes}

The physical properties for three different molarities of the AN104SBS3565 pretreated wastes are provided in Table 1-7. The rheological properties of the AN104SBS3565 pretreated wastes are shown in Table 1-6. The AN104SBS3565 pretreated wastes are all Newtonian in behavior. All the AN104SBS3565 pretreated wastes contained undissolved solids and the settling data is provided in section 4.4.2. Details of the measured physical properties are found in sections 4.4.1.2 and 4.6.4.

The particle size distribution of the undissolved solids for the $4.74 \mathrm{M} \mathrm{Na}$ AN104SBS3565 pretreated wastes was determined. The volume basis data for the pretreated waste had particles that ranged in size between 1.156 to $31.11 \mu \mathrm{m}$. Additional information on the particle size distribution (PSD) of the $4.74 \mathrm{M} \mathrm{Na}$ AN104SBS3565 pretreated waste is located in section 4.7 and Appendix E.

Table 1-6. Averaged Rheological Properties of LAW AN104SBS3565 Pretreated Wastes (PW)

\begin{tabular}{|c|c|c|c|}
\hline $\begin{array}{c}\text { Rheological Model } \\
\text { Newtonian }\end{array}$ & $\begin{array}{c}\text { PW 5.1 M } \\
\mathbf{( 4 . 7 3 ~ M ~ N a} \\
\text { actual) }\end{array}$ & $\begin{array}{c}\text { PW 6.0 M } \\
\mathbf{( 5 . 6 1 ~ M ~ N a} \\
\text { actual) }\end{array}$ & $\begin{array}{c}\text { PW 6.9 M } \\
\text { (6.32 M Na } \\
\text { actual) }\end{array}$ \\
\hline$\mu$-viscosity (Pa-sec) at $25^{\circ} \mathrm{C}$ & $3.20 \mathrm{E}-03$ & $4.38 \mathrm{E}-03$ & $5.24 \mathrm{E}-03$ \\
\hline$\mu-$ viscosity $(\mathrm{Pa}-\mathrm{sec})$ at $40^{\circ} \mathrm{C}$ & $\mathrm{NM}$ & $3.16 \mathrm{E}-03$ & $\mathrm{NM}$ \\
\hline \multicolumn{2}{|c|}{$\mathrm{NM}=$ not measured } \\
\hline
\end{tabular}


WSRC-TR-2004-00232, REVISION 0

SRNL-RPP-2004-00044, REVISION 0

Table 1-7. Averaged Properties of LAW AN104SBS3565 Pretreated Wastes

\begin{tabular}{|c|c|c|c|c|}
\hline Property & Units & $5.1 \mathrm{M}$ & 6.0M & $6.9 \mathrm{M}$ \\
\hline Actual sodium concentration & Molar & 4.73 & 5.61 & 6.32 \\
\hline $\mathrm{pH}$ & $\mathrm{pH}$ & NM & NM & NM \\
\hline Solid phases present & Yes/no & Yes & Yes & Yes \\
\hline Particle size distribution - Mean Volume* & $\mu \mathrm{m}$ & \multicolumn{3}{|c|}{10.41} \\
\hline Particle size distribution - Mean Number* & $\mu \mathrm{m}$ & \multicolumn{3}{|c|}{3.086} \\
\hline Density - Bulk slurry & $\mathrm{g} / \mathrm{mL}$ & 1.23 & 1.26 & 1.30 \\
\hline Density - settled solids & $\mathrm{g} / \mathrm{mL}$ & 1.23 & 1.24 & 1.28 \\
\hline Density - centrifuged solids & $\mathrm{g} / \mathrm{mL}$ & 1.36 & 1.33 & 1.34 \\
\hline Density - supernatant liquid & $\mathrm{g} / \mathrm{mL}$ & 1.23 & 1.26 & 1.31 \\
\hline Vol. \% settled solids after 72 hours & $\%$ & 10.94 & 14.16 & 19.69 \\
\hline Vol. \% centrifuged solids & $\%$ & 6.57 & 9.44 & 12.15 \\
\hline $\mathrm{Wt} \%$ total dried solids & $\%$ & 26.90 & 31.05 & 34.24 \\
\hline Wt $\%$ centrifuged solids & $\%$ & 7.28 & 9.97 & 12.49 \\
\hline Wt \% oven dried solids & $\%$ & 28.61 & 32.93 & 36.37 \\
\hline Wt \% undissolved solids & $\%$ & 0.14 & 0.23 & 0.36 \\
\hline Wt \% dissolved solids & $\%$ & 26.76 & 30.82 & 33.89 \\
\hline $\mathrm{Wt} \%$ soluble solids in supernate & $\%$ & 27.15 & 31.35 & 34.47 \\
\hline $\mathrm{Wt} \%$ dried sample in crucible & $\%$ & 26.91 & 31.03 & 34.63 \\
\hline $\mathrm{Wt} \%$ oxides & $\%$ & 12.37 & 15.40 & 19.20 \\
\hline
\end{tabular}

* Based on 4.7 M Na AN104SBS Pretreated Waste

\subsubsection{Characterization Results of Melter Feed}

The AN104SBS3565 pretreated wastes were adjusted to the original targeted sodium molarities and blended with approved glass former chemicals (GFCs) to make

AN104SBS3565 melter feed. The measured properties for the three different AN-104 melter feed concentrations are provided in Table 1-8. Their rheological properties were obtained at $25^{\circ} \mathrm{C}$ and $40^{\circ} \mathrm{C}$ and the results are shown in Table 1-9 and Table 1-10, respectively. The 6.0 $\mathrm{M} \mathrm{Na}$ melter feed became rheologically thinner, when comparing the rheological properties of the 1 day of mixing to 7 days of mixing results. The cause for this thinning phenomenon is not known, since analysis of the supernatant and settled solids after 1 day and 7 days of mixing were not analyzed. Settling data (see section 4.2.2) seems to support the rheological data, where the solids settled faster after 7 days of mixing as compared to 1 day of mixing for the 6.0 M Na melter feed. The settled solids shear strength results are shown in Table 1-11. Settling data are provided in section 4.4.2. Additional details of the reported measured physical properties are found in sections 4.4.2, 4.5, 4.6.5 and 4.6.6. 
WSRC-TR-2004-00232, REVISION 0

SRNL-RPP-2004-00044, REVISION 0

Table 1-8. Properties of LAW AN104SBS3565 Melter Feed

\begin{tabular}{|c|c|c|c|c|c|}
\cline { 2 - 6 } \multicolumn{1}{c|}{} & \multicolumn{5}{c}{ Sodium Molarity of Starting Pretreated Waste } \\
\hline Property or Condition & Units & $\mathbf{5 . 1} \mathbf{M}$ & $\mathbf{6 . 0} \mathbf{M}$ & $\mathbf{6 . 0} \mathbf{~ M}$ & $\mathbf{6 . 9} \mathbf{~ M}$ \\
\hline Mixing Time & Days & 1 & 1 & 7 & 1 \\
\hline Sodium concentration* & Molar & 3.63 & 4.09 & 4.09 & 4.51 \\
\hline pH & $\mathrm{pH}$ & 11.1 & 11.41 & 11.36 & 11.21 \\
\hline Solid phases present & Yes/no & Yes & Yes & Yes & Yes \\
\hline Particle size distribution - Mean Volume & $\mu \mathrm{m}$ & 23.58 & 27.52 & 15.68 & 21.39 \\
\hline Particle size distribution - Mean Number & $\mu \mathrm{m}$ & 0.674 & 0.691 & 0.667 & 0.643 \\
\hline Density - Bulk slurry & $\mathrm{g} / \mathrm{mL}$ & 1.62 & 1.70 & 1.70 & 1.79 \\
\hline Density - settled solids & $\mathrm{g} / \mathrm{mL}$ & 1.73 & 1.79 & 1.89 & 1.75 \\
\hline Density - centrifuged solids & $\mathrm{g} / \mathrm{mL}$ & 1.85 & 1.89 & 1.95 & 1.85 \\
\hline Density - supernatant liquid & $\mathrm{g} / \mathrm{mL}$ & 1.23 & 1.21 & 1.25 & 1.06 \\
\hline Vol. \% settled solids after 72 hours & $\%$ & 74.2 & 77.7 & 68.4 & 99.3 \\
\hline Vol. \% centrifuged solids & $\%$ & 63.6 & 67.4 & 63.3 & 87.3 \\
\hline Wt \% total dried solids & $\%$ & 57.2 & 61.1 & 61.1 & 66.1 \\
\hline Wt \% centrifuged solids & $\%$ & 72.4 & 75.1 & 72.8 & 90.6 \\
\hline Wt \% oven dried solids & $\%$ & 68.1 & 70.7 & 71.7 & 69.4 \\
\hline Wt \% undissolved solids & $\%$ & 40.0 & 42.5 & 42.2 & 47.4 \\
\hline Wt \% dissolved solids & $\%$ & 17.2 & 18.6 & 18.8 & 18.6 \\
\hline Wt\% soluble solids in supernate & $\%$ & 28.7 & 31.4 & 32.9 & 35.5 \\
\hline Wt\% dried sample in crucible & $\%$ & 57.5 & 61.5 & 61.7 & 66.3 \\
\hline Wt $\%$ oxides & $\%$ & 48.2 & 51.5 & 51.8 & 55.4 \\
\hline
\end{tabular}

* Molarity calculated for melter feed 
Table 1-9. Averaged Rheological Properties of LAW AN104SBS3565 Melter Feeds at $25^{\circ} \mathrm{C}$

\begin{tabular}{|c|c|c|c|c|c|c|c|c|}
\hline \multirow{5}{*}{ Rheological Model: } & \multicolumn{8}{|c|}{ Sodium Molarity of Starting Pretreated Waste } \\
\hline & \multirow{2}{*}{\multicolumn{2}{|c|}{$\begin{array}{c}5.1 \mathrm{M} \\
\text { Mixing Time } 1 \text { Day }\end{array}$}} & \multicolumn{4}{|c|}{$6.0 \mathrm{M}$} & \multirow{2}{*}{\multicolumn{2}{|c|}{$\begin{array}{c}6.9 \mathrm{M} \\
\text { Mixing Time 1 Day }\end{array}$}} \\
\hline & & & \multirow{2}{*}{\multicolumn{2}{|c|}{$\begin{array}{c}\text { Mixing Time } 1 \text { Day } \\
\text { Curve Fitted }\end{array}$}} & \multirow{2}{*}{\multicolumn{2}{|c|}{$\frac{\text { Mixing Time } 7 \text { Days }}{\text { Curve Fitted }}$}} & & \\
\hline & \multicolumn{2}{|c|}{ Curve Fitted } & & & & & \multicolumn{2}{|c|}{ Curve Fitted } \\
\hline & Up & Down & Up & Down & \multicolumn{2}{|r|}{ Down } & Up & Down \\
\hline \multicolumn{9}{|l|}{ Newtonian: } \\
\hline$\mu-$ viscosity (Pa-sec) & 0.0285 & 0.0262 & 0.0461 & 0.0427 & 0.0354 & 0.0329 & 0.3009 & 0.2706 \\
\hline \multicolumn{9}{|l|}{ Ostwald (or Power Law): } \\
\hline $\mathrm{m}-$ consistency coefficient $\left(\mathrm{Pa}-\mathrm{sec}^{\mathrm{n}}\right)$ & 0.1354 & 0.0077 & 0.1920 & 0.0214 & 0.1149 & 0.0206 & 1.2683 & 0.5967 \\
\hline $\mathrm{n}$ - power law coefficient & 0.7571 & 1.1835 & 0.7875 & 1.1029 & 0.8183 & 1.0661 & 0.7834 & 0.8756 \\
\hline \multicolumn{9}{|l|}{ Bingham Plastic (BP): } \\
\hline$\tau_{\mathrm{BP}}-\mathrm{BP}$ yield stress $(\mathrm{Pa})$ & 1.44 & $*$ & 2.53 & $*$ & 1.64 & $*$ & 26.66 & 5.14 \\
\hline$\eta_{\mathrm{BP}}-\mathrm{BP}$ viscosity (Pa-sec) & 0.0264 & * & 0.0423 & $*$ & 0.0329 & * & 0.2609 & 0.2629 \\
\hline Hedstrom Number for 2" pipe & 8638 & $*$ & 6203 & $*$ & 6647 & $*$ & 1809 & 344 \\
\hline \multicolumn{9}{|l|}{ Herschel-Bulkley (HB): } \\
\hline$\tau_{\mathrm{HB}}-\mathrm{HB}$ yield stress $(\mathrm{Pa})$ & 1.35 & $*$ & 0.92 & 0.21 & 0.38 & $*$ & $*$ & 0.43 \\
\hline $\mathrm{k}-\mathrm{HB}$ consistency coefficient $\left(\mathrm{Pa}-\mathrm{sec}^{\mathrm{b}}\right)$ & 0.0284 & $*$ & 0.0883 & 0.0123 & 0.0686 & $*$ & $*$ & 0.3870 \\
\hline $\mathrm{b}-$ HB power law coefficient & 0.9902 & $*$ & 0.8967 & 1.1881 & 0.8968 & $*$ & $*$ & 0.9491 \\
\hline
\end{tabular}

* Fitted rheological parameters not reported due to negative yield stress. 
Table 1-10. Averaged Rheological Properties of LAW AN104SBS3565 Melter Feeds at $40^{\circ} \mathrm{C}$

\begin{tabular}{|c|c|c|c|c|c|c|c|c|}
\hline \multirow{5}{*}{ Rheological Model: } & \multicolumn{8}{|c|}{ Sodium Molarity of Starting Pretreated Waste } \\
\hline & \multirow{2}{*}{\multicolumn{2}{|c|}{$\begin{array}{c}5.1 \mathrm{M} \\
\text { Mixing Time } 1 \text { Day }\end{array}$}} & \multicolumn{4}{|c|}{$6.0 \mathrm{M}$} & \multirow{2}{*}{\multicolumn{2}{|c|}{$\begin{array}{c}6.9 \mathrm{M} \\
\text { Mixing Time 1 Day }\end{array}$}} \\
\hline & & & \multirow{2}{*}{\multicolumn{2}{|c|}{$\begin{array}{c}\text { Mixing Time } 1 \text { Day } \\
\text { Curve Fitted }\end{array}$}} & \multirow{2}{*}{\multicolumn{2}{|c|}{$\frac{\text { Mixing Time } 7 \text { Days }}{\text { Curve Fitted }}$}} & & \\
\hline & \multicolumn{2}{|c|}{ Curve Fitted } & & & & & \multicolumn{2}{|c|}{ Curve Fitted } \\
\hline & Up & Down & Up & Down & Up & Down & $\mathrm{Up}$ & Down \\
\hline \multicolumn{9}{|l|}{ Newtonian: } \\
\hline$\mu-\operatorname{viscosity}(\mathrm{Pa}-\mathrm{sec})$ & 0.0189 & 0.0168 & 0.0321 & 0.0312 & 0.0238 & 0.0219 & 0.1958 & 0.1695 \\
\hline \multicolumn{9}{|l|}{ Ostwald (or Power Law): } \\
\hline $\mathrm{m}-$ consistency coefficient $\left(\mathrm{Pa}-\mathrm{sec}^{\mathrm{n}}\right)$ & 0.0931 & 0.0045 & 0.1314 & 0.0209 & 0.1014 & 0.0189 & 1.4363 & 0.6082 \\
\hline $\mathrm{n}$ - power law coefficient & 0.7509 & 1.1994 & 0.7758 & 0.5076 & 0.7719 & 1.0640 & 0.6949 & 0.8006 \\
\hline \multicolumn{9}{|l|}{ Bingham Plastic (BP): } \\
\hline$\tau_{\mathrm{BP}}-\mathrm{BP}$ yield stress $(\mathrm{Pa})$ & 0.95 & $*$ & 1.17 & $*$ & 1.00 & $*$ & 22.06 & 6.81 \\
\hline$\eta_{\mathrm{BP}}-\mathrm{BP}$ viscosity $(\mathrm{Pa}-\mathrm{sec})$ & 0.0175 & $*$ & 0.0302 & $*$ & 0.0221 & $*$ & 0.1626 & 0.1593 \\
\hline Hedstrom Number for 2" pipe & 12969 & $*$ & 5628 & $*$ & 8982 & $*$ & 3854 & 1240 \\
\hline \multicolumn{9}{|l|}{ Herschel-Bulkley (HB): } \\
\hline$\tau_{\mathrm{HB}}-\mathrm{HB}$ yield stress $(\mathrm{Pa})$ & 0.96 & $*$ & 1.20 & $*$ & 0.83 & 0.02 & $*$ & 0.94 \\
\hline $\mathrm{k}-\mathrm{HB}$ consistency coefficient $\left(\mathrm{Pa}-\mathrm{sec}^{\mathrm{b}}\right)$ & 0.0179 & $*$ & 0.0297 & $*$ & 0.0261 & 0.0107 & $*$ & 0.3410 \\
\hline $\mathrm{b}-$ HB power law coefficient & 1.0003 & * & 1.0026 & $*$ & 0.9787 & 1.1270 & * & 0.9035 \\
\hline
\end{tabular}

* Fitted rheological parameters not reported due to negative yield stress. 
WSRC-TR-2004-00232, REVISION 0

SRNL-RPP-2004-00044, REVISION 0

Table 1-11. Settled Solids Shear Strength of LAW AN104SBS3565 Melter Feed

\begin{tabular}{|c|c|c|c|c|c|}
\hline \multirow{4}{*}{$\begin{array}{c}\text { Vane } \\
\text { submerged } \\
(\mathrm{cm})\end{array}$} & \multicolumn{5}{|c|}{ Sodium Molarity of Starting Pretreated Waste } \\
\hline & \multirow{2}{*}{$\begin{array}{c}\text { 5.1 M Na Mixing } \\
\text { Time 1 Day }\end{array}$} & \multicolumn{3}{|c|}{$6.0 \mathrm{M} \mathrm{Na}$} & \multirow{2}{*}{$\begin{array}{l}6.9 \mathrm{M} \mathrm{Na} \text { Mixing } \\
\text { Time } 1 \text { Day }\end{array}$} \\
\hline & & \multicolumn{2}{|c|}{ Mixing Time 1 Day } & Mixing Time 7 Days & \\
\hline & $\begin{array}{l}\text { Settled } 48 \mathrm{hrs} \\
\quad(\mathrm{Pa})\end{array}$ & $\begin{array}{c}\text { Settled } 48 \\
\mathrm{hrs}(\mathrm{Pa})\end{array}$ & $\begin{array}{c}\text { Settled } 96 \\
\text { hrs }(\mathrm{Pa})\end{array}$ & $\begin{array}{l}\text { Settled } 48 \text { hrs } \\
\quad(\mathrm{Pa})\end{array}$ & $\begin{array}{l}\text { Settled } 48 \mathrm{hrs} \\
\quad(\mathrm{Pa})\end{array}$ \\
\hline 3.2 & 8.1 & 16.3 & 10.9 & 9.9 & 48.4 \\
\hline 5.2 & 21.4 & 17.0 & 18.6 & 19.3 & 80.2 \\
\hline
\end{tabular}

The particle size distributions of the undissolved solids for the AN104SBS3565 melter feeds were determined. The volume basis data for the melter feed indicates that the particles ranged between 0.172 to $352.0 \mu \mathrm{m}$. The melter feeds have bimodal or tri-modal distributions of particles, which are not uncommon or unexpected of melter feeds using individual glass formers that range widely in particle size. Additional information on the PSD of the melter feeds is located in section 4.7 and Appendix E.

\subsection{QUALITY REQUIREMENTS}

This work was conducted in accordance with the RPP-WTP QA requirements specified for work conducted by SRTC as identified in DOE IWO M0SRLE60. Researchers followed the SRTC QA program, which has been approved by WTP, and the WSRC QA Management Plan (WSRC-RP-92-225). The program applied the appropriate QA requirements for this task, as indicated by the QA Plan Checklist in section IX of the Task Technical and Quality Assurance Plan (Crawford 2003).

Analytical sample labeling and tracking complied with established procedures (WSRC L1, Procedure 7.15). The Immobilization Technology Section (ITS) conducted all analyses using the routine level QA program. Calibrated measuring equipment was utilized. The Task Technical and Quality Assurance Plan (Crawford 2003) provided the quality requirements for this work. NQA-1 1989, Basic and Supplementary Requirements and NQA-2a 1990, Part 2.7 were applied as appropriate. 


\section{WSRC-TR-2004-00232, REVISION 0 SRNL-RPP-2004-00044, REVISION 0}

\subsection{R\&T TEST CONDITIONS}

Table 1-12 lists the various testing conditions and if the tests conditions were followed in this task.

Table 1-12. R\& T Test Conditions for Evaporation, Rheology and Vitrification

\begin{tabular}{|c|c|}
\hline R\&T Test Conditions & Were Test Conditions Followed? \\
\hline $\begin{array}{l}\text { Operate at Design Basis Temperature }\left(50^{\circ} \mathrm{C} \text {, nominally }\right. \\
60 \text { to } 80 \text { torr })\end{array}$ & $\begin{array}{l}\text { Yes. See Section } 3.1 .2 \text { for experimental details for } \\
\text { evaporation testing. }\end{array}$ \\
\hline $\begin{array}{l}\text { Concentrate AN-104 mixed with SBS recycle up to } 6 \mathrm{M} \\
\text { Sodium }\end{array}$ & $\begin{array}{l}\text { Yes/No. The final AN104SBS4555 pretreated waste } \\
\text { was concentrated to within } 10 \% \text { of the targeted } 6 \mathrm{M} \\
\text { sodium as discussed in Section 3.2.3. The final } \\
\text { AN104SBS3545 pretreated waste was concentrated to } \\
6.75 \mathrm{M} \mathrm{Na} \text { (measured at } 7.29 \mathrm{M} \mathrm{Na} \text {, but later } \\
\text { recalculated to } 6.75 \mathrm{M} \mathrm{Na}-\text { see Appendix B). It } \\
\text { should be noted that the initial objectives specified in } \\
\text { the Test Specification for evaporator concentration } \\
\text { endpoints were given as nominally } 6,8 \text { and } 10 \mathrm{molar} \\
\text { sodium. However as the TTP evolved and melter } \\
\text { studies were performed at VSL (Matlock } 2003 \text { ) and } \\
\text { GTS Duratek (Duratek 2003), this concentration } \\
\text { endpoint for the evaporator concentrate was targeted } \\
\text { per WTP direction (See Test Exception Number: } \\
24590-L A W-T E F-R T-04-0001 \text {, Rev. } 0 \text { ) at } 6 \mathrm{M} \text { sodium } \\
\text { with the upper and lower targets set at }+15 \% \text { of the } 6 \\
\text { M sodium target. This is representative of the pilot } \\
\text { scale testing conducted by Duratek. }\end{array}$ \\
\hline $\begin{array}{l}\text { Samples of the concentrate stream will be analyzed for } \\
\text { cations, anions, TOC, solids content (total and } \\
\text { suspended), density, and radionuclides. }\end{array}$ & $\begin{array}{l}\text { Yes/No. See Section } 3.2 .3 \text { for analytical results. A full } \\
\text { suite of radionuclide analyses was not performed. Test } \\
\text { Exception Number: } 24590-\text { WTP-TEF-RT-03-077 } \\
\text { deleted the requirements to characterize the AN-104 } \\
\text { LAW glass so there was no need to perform } \\
\text { radioactivity characterization of the Vitrification feed } \\
\text { components and glass, except for waste stream and } \\
\text { evaporator process characterization by gamma energy } \\
\text { analysis (GEA) as specified in Test Exception Number: } \\
\text { 24590-LAW-TEF-RT-04-0001. }\end{array}$ \\
\hline $\begin{array}{l}\text { Solids that precipitate at any point in the process will be } \\
\text { analyzed to determine solids speciation. }\end{array}$ & $\begin{array}{l}\text { No. See Section } 3.2 .4 \text { for analytical results. Since } \\
\text { concentrate samples were destined for vitrification } \\
\text { studies that targeted GTS Duratek pilot results (See } \\
\text { Approved TTP), boildown past saturation was not } \\
\text { performed. }\end{array}$ \\
\hline Heat Capacity measurements conducted on concentrate. & $\begin{array}{l}\text { No. Heat capacity measurements were deleted by WTP } \\
\text { R\&T per Test Exception Number: } 24590-\mathrm{LAW}-\mathrm{TEF}- \\
\text { RT-04-0001. Heat capacity measurements on } \\
\text { simulants (Josephs 2003) were deemed to be sufficient. }\end{array}$ \\
\hline $\begin{array}{l}\text { SBS samples will be analyzed for cations, anions, TOC, } \\
\text { radionuclides, and } \mathrm{pH} \text {. If } \mathrm{pH} \text { adjustment is required } \\
\text { only solids analysis will be conducted. }\end{array}$ & $\begin{array}{l}\text { Yes. See sections } 3.1 .1 \text { and } 3.1 .2 \text { and Table A-1 for } \\
\text { analytical results. }\end{array}$ \\
\hline
\end{tabular}


WSRC-TR-2004-00232, REVISION 0
SRNL-RPP-2004-00044, REVISION 0

Table 1-12. R\& T Test Conditions for Evaporation, Rheology and Vitrification

\begin{tabular}{|c|c|}
\hline R\&T Test Conditions & Were Test Conditions Followed? \\
\hline $\begin{array}{l}\text { Condensate samples will be analyzed for cations, } \\
\text { anions, TOC, radionuclides, and } \mathrm{pH} \text {. }\end{array}$ & $\begin{array}{l}\text { Yes. See Section } 3.2 .3 \text { for analytical results. A full } \\
\text { suite of radionuclide analyses was not performed. }\end{array}$ \\
\hline $\begin{array}{l}\text { Physical and rheological properties and } \mathrm{pH} \text { will be } \\
\text { measured for the pretreated AN-104 actual waste } \\
\text { sample. Solids concentration, settling rate (if solids are } \\
\text { present), density, pH, and shear stress versus shear rate } \\
\text { flow curves will be measured on these samples after } \\
\text { evaporation to three different sodium concentrations } \\
\text { (typically } 6,8 \text { and } 10 \mathrm{M} \text { Na). The exact concentrations } \\
\text { will be confirmed at a later date and will be clearly } \\
\text { specified in the test plan. Rheology measurements will } \\
\text { be performed at } 25^{\circ} \mathrm{C} \pm 1^{\circ} \mathrm{C} \text { and at } 40^{\circ} \mathrm{C} \pm 1^{\circ} \mathrm{C} \text {. }\end{array}$ & $\begin{array}{l}\text { Yes/No, see data in section } 4.0 \text {. The pretreated waste } \\
\text { rheological measurements were only conducted at } 25^{\circ} \mathrm{C} \\
\text { (See Table } 4-15 \text { ) for the } 5.1 \mathrm{M} \mathrm{Na} \text { and } 6.9 \mathrm{M} \mathrm{Na} \\
\text { pretreated wastes, and were conducted at } 25^{\circ} \mathrm{C} \text { and } \\
40^{\circ} \mathrm{C} \text { for the } 6 \mathrm{M} \text { Na pretreated waste. The viscosity } \\
\text { decreased with increasing temperature for the } 6 \mathrm{M} \\
\text { pretreated waste, as expected. Previous testing with } \\
\text { simulants (Hansen } 2000 \text { ) indicates that viscosity } \\
\text { reduction with increasing temperature is sodium } \\
\text { concentration dependent. The ratio of the viscosity } \\
\text { between } 50^{\circ} \mathrm{C} \text { and } 25^{\circ} \mathrm{C} \text { (Hansen } 2000 \text { ) became smaller } \\
\text { as the sodium concentration increases, though not by } \\
\text { much. If the } 6.0 \mathrm{M} \mathrm{Na} \text { pretreated waste viscosity ratio } \\
\text { between } 40^{\circ} \mathrm{C} \text { and } 25^{\circ} \mathrm{C} \text { is used to determine the } \\
\text { viscosity of the } 5.1 \mathrm{M} \text { Na and } 6.0 \mathrm{M} \text { Na pretreated } \\
\text { wastes at } 40^{\circ} \mathrm{C} \text {, the viscosity would be slightly under- } \\
\text { estimated and slightly over-estimated respectively. }\end{array}$ \\
\hline $\begin{array}{l}\text { Shear stress versus shear rate flow curves and constant } \\
\text { rate analyses, particle size distribution, solids } \\
\text { concentration and settling rate, density and } \mathrm{pH} \text {, will } \\
\text { also be conducted on three blended samples (typically } \\
6,8 \text { and } 10 \mathrm{M} \text { ) after addition of the prescribed } \\
\text { quantities of glass formers (glass former chemicals, } \\
\text { quantity, and vendor name to be specified by the WTP } \\
\text { project). Rheological measurements (flow curves and } \\
\text { constant shear rates) will be measured after } 1 \text { hour of } \\
\text { mixing. }\end{array}$ & $\begin{array}{l}\text { Yes, for all measurements, see section 4.0. Rheological } \\
\text { measurements after one hour were not conducted, so as } \\
\text { to be consistent with past AZ-102 testing (Hansen } \\
\text { 2003). Constant shear rates measurements were not } \\
\text { performed. Resulting flow curves, at the hold } \\
\text { conditions, showed little change in the measured shear } \\
\text { stress, indicating that the consistent shear rate } \\
\text { measurements would have not produced unique data. }\end{array}$ \\
\hline $\begin{array}{l}\text { A separate test using one of the above samples will be } \\
\text { replicated with additional } 1 \text { day and } 1 \text { week mixing } \\
\text { periods prior to flow curve and constant shear rate } \\
\text { measurements. }\end{array}$ & $\begin{array}{l}\text { Yes. See section 4.0. The } 6.0 \mathrm{M} \mathrm{Na} \text { AN104SBS3565 } \\
\text { melter feed was processed after } 1 \text { day and } 1 \text { week of } \\
\text { mixing. }\end{array}$ \\
\hline $\begin{array}{l}\text { The nominal targeted melter feed, after } 1 \text { week of } \\
\text { mixing, will then be allowed to settle for } 1 \text { week at } \\
\text { which time the supernate will removed and the } \\
\text { undisturbed settled solids layer will be analyzed for } \\
\text { shear strength at ambient temperature by the vane test. }\end{array}$ & $\begin{array}{l}\text { No. The } 6.0 \mathrm{M} \text { Na AN104SBS3565 melter feed settled } \\
\text { solids shear strengths were measured using the vane } \\
\text { test after } 48 \text { and } 96 \text { hours of settling after } 1 \text { day of } \\
\text { mixing, and after } 48 \text { hours of settling after } 7 \text { days of } \\
\text { mixing. The settled solids shear strength for all of the } \\
6.0 \mathrm{M} \text { Na AN104SBS3565 melter feeds were an order } \\
\text { of magnitude lower than the maximum settled solids } \\
\text { shear strength bounding condition. For the } 1 \text { day of } \\
\text { mixing } 6.0 \mathrm{M} \text { Na melter feed, there was no difference } \\
\text { or increase in the settled solids shear strength between } \\
48 \text { and } 96 \text { hours of settling. This combination of } \\
\text { pretreated waste and GFCs do not seem to produce the } \\
\text { high settled solids shear strengths of other radioactive } \\
\text { LAW melter feeds (Hansen, } 2003 \text { and Bredt } 2003 \text { ). } \\
\text { This data indicates that the settled solids shear strength } \\
\text { after } 7 \text {-day settling will not approach the bonding } \\
\text { condition of } 625 \text { Pa. See section } 4.6 .6 \text { for additional }\end{array}$ \\
\hline
\end{tabular}


WSRC-TR-2004-00232, REVISION 0

SRNL-RPP-2004-00044, REVISION 0

Table 1-12. R\& T Test Conditions for Evaporation, Rheology and Vitrification

\begin{tabular}{|l|l|}
\hline R\&T Test Conditions & Were Test Conditions Followed? \\
\hline $\begin{array}{l}\text { Flow curves and constant rate shear measurements will } \\
\text { then be collected at } 25^{\circ} \mathrm{C} \pm 1^{\circ} \mathrm{C} \text { and at } \\
40^{\circ} \mathrm{C} \pm 1{ }^{\circ} \mathrm{C} . \text { Solids and density measurements of the } \\
\text { settled solids layer will also be obtained. }\end{array}$ & Yes, see section 4.0. \\
\hline $\begin{array}{l}\text { Rheological properties, physical properties, pH, and } \\
\text { particle size distribution measurements described in this } \\
\text { document are to be performed and reported according } \\
\text { to approved procedures issued by the project. }\end{array}$ & Yes, see section 4.0. \\
\hline $\begin{array}{l}\text { Glass formulation using specified minerals supplied by } \\
\text { VSL. }\end{array}$ & $\begin{array}{l}\text { Yes. Approved glass forming minerals were used in } \\
\text { the glass formulation as discussed in Section 4. }\end{array}$ \\
\hline $\begin{array}{l}\text { Glass formulation based on characterization data for the } \\
\text { radioactive AN-104 supernate. }\end{array}$ & $\begin{array}{l}\text { Yes. Characterization data for the pretreated AN-104 } \\
\text { mixed with SBS A3 recycle were transmitted to WTP } \\
\text { by SRNL for consideration for glass recipe formulation } \\
\text { as discussed in Section 5. }\end{array}$ \\
\hline $\begin{array}{l}\text { The simulated center-line cooling curve for LAW glass } \\
\text { supplied by RPP-WTP will be used for all Vitrification } \\
\text { tests. }\end{array}$ & $\begin{array}{l}\text { Yes. The canister centerline cooling (CCC) data } \\
\text { supplied by WTP (See Appendix F) to SRNL was } \\
\text { programmed into the furnaces used for this task. }\end{array}$ \\
\hline $\begin{array}{l}\text { Crucible Vitrification was carried out in Pt/Au crucibles } \\
\text { and included an evaporation phase, a calcining phase, a } \\
\text { melter phase and applied controlled cooling. }\end{array}$ & $\begin{array}{l}\text { Yes. Vitrification was carried out in Pt/Au crucibles } \\
\text { and included the steps as shown in Section 5. }\end{array}$ \\
\hline $\begin{array}{l}\text { Elemental analyses, dissolution techniques, } \\
\text { radionuclide analyses, crystalline and non-crystalline } \\
\text { phase identification and measurement, and the Product } \\
\text { Consistency Tests to be conducted on product glass. }\end{array}$ & $\begin{array}{l}\text { No. Test conditions associated with these tests on the } \\
\text { product glass were removed per Test Exception } \\
\text { (Prindiville 2003). }\end{array}$ \\
\hline
\end{tabular}

\subsection{SIMULANT USE}

\subsubsection{Evaporation Tests}

The evaporation portion of this study used a radioactive AN-104 pretreated waste blended with a simulated recycle stream, SBS A3 from Duratek, the product of the two blends called AN104SBS pretreated waste. The SBS A3 recycle was generated using the Duratek DM3300 melter and melter feed based upon subenvelope A3 glass composition. No comparable tests have been conducted with recycle streams generated using actual waste, so no comparison of that type is possible. In this study, the AN104SBS3565 pretreated waste densities are similar to those observed in the simulant study (Josephs 2003) for a given sodium molarity. In addition, boiling points measured during the LAW AN104SBS pretreated waste testing are comparable to simulant LAW waste boiling temperatures observed in the vapor pressure range of 60 to $80 \mathrm{~mm} \mathrm{Hg}$ (Josephs 2003). 


\subsubsection{Rheology and Physical Properties Tests}

The viscosities of the LAW AN104SBS3565 pretreated wastes in the current study (Table 1-6) were similar to the highest viscosities observed in the 12 different simulant Envelope A pretreated wastes (Josephs 2003).

A 6.0 M Na AN-104 pretreated waste simulant with SBS recycle and approved GFCs melter feed was made by VSL (Muller 2004) and characterized for rheology and oxide composition. Comparison of these characteristics show that for this $6.0 \mathrm{M} \mathrm{Na}$ melter feed, the VSL simulant is physically and chemically similar to the actual AN104SBS3565 6.0 M Na melter feed characterized by SRNL. This comparison is only applicable to the $6.0 \mathrm{M}$ Na melter feed.

The $1^{\text {st }}$ flow curve of the AN104SBS3565 6.0 M Na melter feed at $25^{\circ} \mathrm{C}$ after 1 day of mixing and 7 days of mixing were compared to the VSL melter feed simulant and the results are shown in Figure 1-1 and Table 1-13. Figure 1-1 contains the flow curves, which show that the VSL flow curve is between both the SRNL 1 day and 7 days of mixing flow curves. The flow curves were fitted to a Newtonian model and the results are shown in Table 1-13. The VSL viscosity is $7.7 \%$ lower than SRNL 1 day of mixing and $19.4 \%$ larger than SRNL 7 days of mixing viscosities.

Table 1-13. Newtonian Results of 6.0 M Na AN104SBS3565 and VSL Melter Feeds

\begin{tabular}{|c|c|c|}
\hline Fluid & Viscosity (Pa·s) & $\mathbf{R}^{\mathbf{2}}$ \\
\hline SRNL 6.0 M Na Melter Feed 1 day of mixing & 0.0453 & 0.9817 \\
\hline SRNL 6.0 M Na Melter Feed 7 days of mixing & 0.0350 & 0.9892 \\
\hline VSL 6.0 M Melter Feed & 0.0418 & 0.9950 \\
\hline
\end{tabular}


WSRC-TR-2004-00232, REVISION 0

SRNL-RPP-2004-00044, REVISION 0

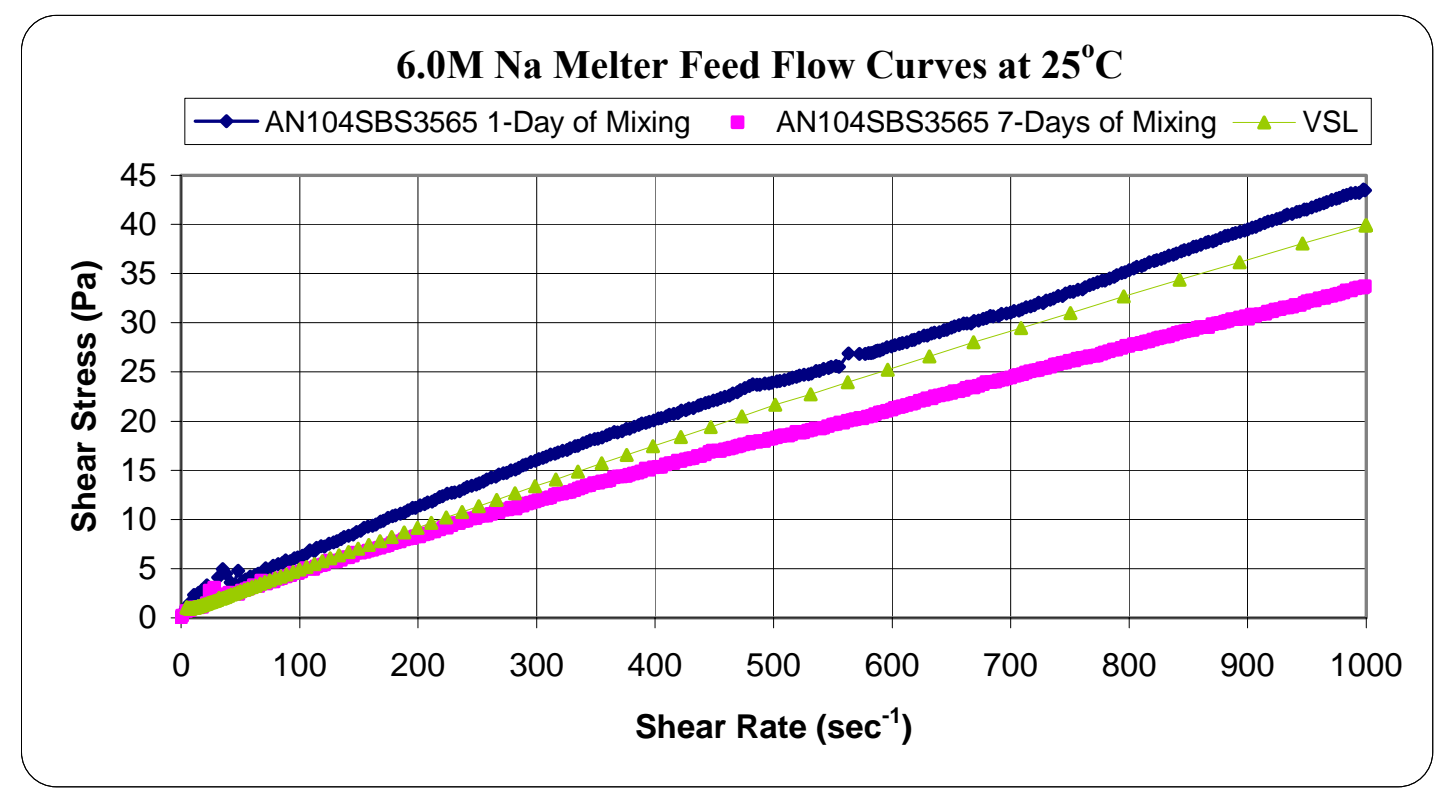

Figure 1-1. 6.0 M Na AN104SBS3565 and VSL AN-104 Melter Feed Flow Curves

The LA137SRCCC VSL data in Table 5 of (Muller 2004) were re-normalized after removing $\mathrm{F}, \mathrm{Cl}$ and $\mathrm{Cs}_{2} \mathrm{O}$ contributions (these contributions were negligible) when comparing the oxides of the VSL and AN104SBS3565 melter feeds at 6.0 M Na. SRNL used VSL batching sheet (Table 4-2) to make the AN104SBS3565 melter feed and the $6.0 \mathrm{M} \mathrm{Na}$ data in the batching sheet was used to determine the oxide composition of the glass, using SRNL basis (Schumacher 2002) for the individual GFC compositions. The oxide results of the $6.0 \mathrm{M} \mathrm{Na}$ melter feeds are shown in Table 1-14, which show good agreement between all data sets.

\subsubsection{Vitrification Tests}

It is not possible to compare any radioactive LAW AN104SBS3565 glass properties (analyzed metals, PCT response, and crystalline phase identification) to simulant AN-104 LAW glass because these tests were not performed on the radioactive glass per the Test Exception (Prindiville 2003). The only comparison is the visual appearance of the crucible glasses after CCC of the crucible melts. It has been reported for the simulant glass per Table 4 of Muller 2004, that the LA137SRCCC simulant glass product resulted in a 'dark brown, homogeneous glass'. This was also the appearance of the radioactive LAW AN104SBS3565 glass with CCC produced in this study as detailed in Section 5.0.

\subsection{DISCREPANCIES AND FOLLOW-ON TESTS}

No discrepancies and follow-on tests are recommended. 
WSRC-TR-2004-00232, REVISION 0 SRNL-RPP-2004-00044, REVISION 0

Table 1-14. Elemental and Oxide Composition of AN104SBS3565 and VSL Pretreated Wastes and Melter Feeds at 6 M Na

\begin{tabular}{|c|c|c|c|c|c|c|c|c|}
\hline \multicolumn{3}{|c|}{ Pretreated Waste } & \multicolumn{6}{|c|}{$\begin{array}{c}\text { Melter Feed } \\
\text { ( values shown as \% of total melter feed on an oxide basis) }\end{array}$} \\
\hline \multirow[b]{2}{*}{ Element } & \multirow{2}{*}{\begin{tabular}{|c|} 
VSL \\
(Table 4-2) \\
$6.0 \mathrm{M} \mathrm{Na}$ \\
$\mathrm{mg} / \mathrm{L}$ \\
\end{tabular}} & \multirow{2}{*}{\begin{tabular}{|c|} 
AN104SB \\
S3565 \\
$6.0 \mathrm{M}$ Na \\
$\mathrm{mg} / \mathrm{L}$ \\
\end{tabular}} & \multirow[b]{2}{*}{ Oxide } & \multirow[b]{2}{*}{$\begin{array}{l}\text { VSL* 6.0 } \\
\text { M Na }\end{array}$} & \multirow{2}{*}{\begin{tabular}{|c|} 
AN104SB \\
S3565 \\
$6.0 \mathrm{M} \mathrm{Na}$
\end{tabular}} & \multicolumn{3}{|c|}{ LA137SRCC } \\
\hline & & & & & & $\begin{array}{c}\text { Calculated } \\
\text { Target }\end{array}$ & $\mathrm{XRF}^{*}$ & $\begin{array}{l}\text { DCP- } \\
\text { AES* }\end{array}$ \\
\hline $\mathrm{Al}$ & 22979 & 15872 & $\mathrm{Al}_{2} \mathrm{O}_{3}$ & $25 \%$ & $5.22 \%$ & $6.10 \%$ & $5.79 \%$ & $5.85 \%$ \\
\hline B & & 612 & $\mathrm{~B}_{2} \mathrm{O}_{3}$ & $10.19 \%$ & $10.31 \%$ & $9.99 \%$ & $9.87 \%$ & $10.48 \%$ \\
\hline $\mathrm{Ca}$ & & 40.3 & $\mathrm{CaO}$ & $5.11 \%$ & $5.18 \%$ & $5.07 \%$ & $4.87 \%$ & $4.73 \%$ \\
\hline $\mathrm{Ce}$ & 0 & & $\mathrm{Ce}_{2} \mathrm{O}_{3}$ & & $0.00 \%$ & - - - & -- & --- \\
\hline $\mathrm{Cr}$ & & & $\mathrm{Cr}_{2} \mathrm{O}_{3}$ & $\%$ & $0.03 \%$ & $0.03 \%$ & $0.05 \%$ & $0.05 \%$ \\
\hline $\mathrm{Fe}$ & 53.4 & .9 & $\mathrm{Fe}_{2} \mathrm{O}_{3}$ & $5.29 \%$ & $5.37 \%$ & $5.40 \%$ & $5.26 \%$ & $5.24 \%$ \\
\hline $\mathrm{K}$ & 6523 & 3783 & & $3 \%$ & $0.37 \%$ & $0.62 \%$ & $.65 \%$ & $0.69 \%$ \\
\hline $\mathrm{Li}$ & & & ${ }_{2} \mathrm{O}$ & & $\%$ & & $47 \%$ & $39 \%$ \\
\hline $\mathrm{Mg}$ & 25.4 & 6.1 & $\mathrm{MgO}$ & $1.44 \%$ & $1.46 \%$ & $1.49 \%$ & $1.46 \%$ & $1.59 \%$ \\
\hline $\mathrm{Mn}$ & 0 & 0 & $\mathrm{nO}$ & $2 \%$ & $0.02 \%$ & $-\ldots$ & $-\ldots$ & $-\ldots$ \\
\hline Mo & & & $\mathrm{MoO}_{3}$ & & $\%$ & --- & --- & --- \\
\hline $\mathrm{Na}$ & 137940 & 137751 & $\mathrm{Na}_{2} \mathrm{O}$ & $14.78 \%$ & $14.72 \%$ & $14.76 \%$ & $14.83 \%$ & $13.20 \%$ \\
\hline $\mathrm{Ni}$ & 0 & 0 & $\mathrm{NiO}$ & $0.01 \%$ & $0.01 \%$ & $-\ldots$ & $\ldots$ & $-\ldots$ \\
\hline $\mathrm{P}$ & 0 & 440 & $\mathrm{P}_{2} \mathrm{O}_{5}$ & $0.00 \%$ & $0.08 \%$ & $0.11 \%$ & $0.16 \%$ & $0.20 \%$ \\
\hline $\mathrm{Pb}$ & 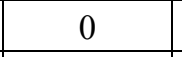 & & $\mathrm{PbO}$ & $0.00 \%$ & & $-\ldots$ & $-\cdots$ & $-\cdots$ \\
\hline $\mathrm{S}$ & 1433 & & $\mathrm{SO}_{3}$ & $0.29 \%$ & $0.43 \%$ & $0.28 \%$ & $0.27 \%$ & $0.00 \%$ \\
\hline $\mathrm{Sb}$ & 0 & 44.6 & $\mathrm{Sb}_{2} \mathrm{O}_{3}$ & $0.00 \%$ & $0.00 \%$ & $-\ldots$ & $-\ldots$ & $-\ldots$ \\
\hline $\mathrm{Si}$ & 401.9 & & $\mathrm{SiO}_{2}$ & $46.18 \%$ & $46.87 \%$ & $46.42 \%$ & $47.12 \%$ & $48.43 \%$ \\
\hline $\mathrm{Sn}$ & 0 & 37.1 & $\mathrm{SnO} 2$ & $0.00 \%$ & $0.00 \%$ & $-\ldots$ & $-\ldots$ & $-\cdots$ \\
\hline $\mathrm{Sr}$ & 0 & 9.2 & $\mathrm{SrO}$ & $0.00 \%$ & $0.00 \%$ & $-\cdots$ & $-\cdots$ & $-\cdots$ \\
\hline $\mathrm{Ti}$ & 22.5 & 5.8 & $\mathrm{TiO}_{2}$ & $1.17 \%$ & $1.19 \%$ & $1.14 \%$ & $1.23 \%$ & $1.27 \%$ \\
\hline $\mathrm{U}$ & 0 & 62.1 & $\mathrm{U}_{3} \mathrm{O}_{8}$ & $0.00 \%$ & $0.01 \%$ & $-\ldots$ & $-\ldots$ & $-\cdots$ \\
\hline $\mathrm{V}$ & 0 & 4.5 & $\mathrm{~V}_{2} \mathrm{O}_{5}$ & $0.01 \%$ & $0.01 \%$ & $-\cdots$ & $-\cdots$ & $-\ldots$ \\
\hline $\mathrm{Zn}$ & 81.4 & 60.9 & $\mathrm{ZnO}$ & $3.07 \%$ & $3.11 \%$ & $3.06 \%$ & $2.87 \%$ & $2.97 \%$ \\
\hline $\mathrm{Zr}$ & 11.1 & 3.1 & $\mathrm{ZrO}_{2}$ & $3.03 \%$ & $3.07 \%$ & $3.02 \%$ & $3.11 \%$ & $2.92 \%$ \\
\hline
\end{tabular}

* XRF and DCP data are normalized to $100 \%$ 
WSRC-TR-2004-00232, REVISION 0

SRNL-RPP-2004-00044, REVISION 0

This page intentionally left blank. 
WSRC-TR-2004-00232, REVISION 0

SRNL-RPP-2004-00044, REVISION 0

\subsection{CD-ROM ENCLOSURES}

A CD was issued for this work under document number SRNL-RPP-2004-00065, Antifoam Testing with AN104SBS pretreated waste (Crowder 2004). An electronic copy of WSRCTR-2004-00232 (SRNL-RPP-2004-00044) is also included on the CD-ROM. 
WSRC-TR-2004-00232, REVISION 0

SRNL-RPP-2004-00044, REVISION 0

This page intentionally left blank. 
WSRC-TR-2004-00232, REVISION 0

SRNL-RPP-2004-00044, REVISION 0

\subsection{EVAPORATION}

\subsection{EXPERIMENTAL DESCRIPTION}

\subsubsection{Blending AN-104 Pretreated Waste and SBS A3 Recycle}

The key portion of the final evaporator feed originated from Hanford Tank 241-AN-104. This tank is in Envelope A (subset A3) of the wastes to be treated by the RPP-WTP pretreatment facility. The radioactive LAW AN-104 waste was diluted, characterized, and treated for cesium removal by ion exchange at SRNL. The resulting pretreated AN-104 Ion Exchange (IX) effluent sample (AN-104 pretreated waste), about $3 \mathrm{~L}$, was used for these experiments, and was blended with a simulated recycle stream, submerged bed scrubber (SBS) A3, generated by Duratek. The SBS is a processing step in the RPP-WTP Low Activity Waste (LAW) vitrification process melter feed off gas system. The SBS material contains glass-former solids, glass, and simulated A3 supernate. Previously, the SBS A3 sample has also been identified as RM-01-023.

The major metals components of the AN-104 pretreated waste, SBS A3 recycle, and the blend of the AN104 pretreated waste and SBS A3 recycle are shown in Table 3-1. The sodium molarity of the AN104 pretreated waste and SBS A3 recycle prior to blending the two were $4.74 \mathrm{M}$ and $0.097 \mathrm{M}$ respectively. The first data column in Table 3-1 shows the AN-104 pretreated waste (ion exchange effluent) that did not contain any visible suspended solids. The next two data columns in Table 3-1 show the SBS A3 recycle and AN-104 pretreated waste blended at a volume ratio of 35 percent AN-104 pretreated waste to 65 percent SBS A3 recycle. This blend of 35 volume $\% 4.74 \mathrm{M} \mathrm{Na}$ AN-104 pretreated waste to $65 \% 0.097 \mathrm{M} \mathrm{Na}$ SBS A3 recycle will be denoted as AN104SBS3565. The values reported in Table 3-1 represent the average of two samples. Comparison of the final two columns in Table 3-1 shows that most measured concentrations in the AN104SBS3565 pretreated waste are nominally within $+/-10 \%$ of the calculated values based on the volumetric blends ratio and using the measured concentrations in the AN-104 pretreated waste and SBS A3 recycle. Interestingly, the concentrations of calcium $(\mathrm{Ca})$, lithium $(\mathrm{Li})$, and magnesium $(\mathrm{Mg})$ in the AN104SBS3565 pretreated feed were lower than expected. In each case, these components were more prevalent in SBS A3 recycle than in AN-104 pretreated waste. Some precipitation of these minor components may have occurred in the blends.

Table 3-2 shows other characterization data for the AN-104 pretreated waste, SBS A3 recycle and initial AN104SBS3565 pretreated waste. Samples of SBS A3 recycle and the AN104SBS3565 pretreated waste contained visible suspended solids and the solids were filtered prior to the chemical analyses, but samples for specific gravity and percent solids determinations were not filtered prior to analyses. The $\mathrm{pH}$ of the SBS A3 recycle was 7.35, and therefore no $\mathrm{pH}$ adjustment was needed to the SBS A3 recycle. Table 3-2 also shows the measured radionuclides in the AN-104 and AN104SBS3565 pretreated wastes. The data indicates that the Sr-90 and Tc-99 are the predominant radionuclides present at orders of magnitude higher than the measured Cs-137 that had been removed by a Cs-ion exchange pretreatment process. An anomaly in Table 3-2 is the Sr-90 level in the blend, which is almost an order of magnitude less than expected from dilution alone. The low value may be 
WSRC-TR-2004-00232, REVISION 0

SRNL-RPP-2004-00044, REVISION 0

due to partial precipitation of Sr with some component of SBS A3 recycle, such as manganese. In fact, the concentration of $\mathrm{Sr}$ was higher in the solids from the

AN104SBS3565 pretreated waste than in the solids from SBS A3 recycle, as shown in Table 3-9.

Evaporator runs were conducted with two different volumetric blends of AN-104 pretreated waste to SBS A3 cycle. One was the AN104SBS3565 as described above. The other is a blend of 45 volume $\% 4.74 \mathrm{M} \mathrm{Na}$ AN-104 pretreated waste to $55 \% 0.097 \mathrm{M} \mathrm{Na}$ SBS A3 recycle and will be denoted as AN104SBS4555. These blend ratios were chosen as representative of the blend ratios found in unpublished model results of the RPP-WTP process (Longwell 2003) as described in Appendix A. The major metals components of the AN-104 pretreated waste, SBS A3 recycle and AN014SBS4555 pretreated waste are shown in Table 3-3.

The concentrate product from the AN104SBS3565 was targeted for further scope including rheology and physical properties measurements and Low Activity Waste (LAW) glass formulation and crucible-scale Vitrification. AN104SBS is denoted in this document as 4.7 M Na AN104 pretreated waste blended with $0.097 \mathrm{M} \mathrm{Na}$ SBS A3 recycle. The numbers after this denotation specify the volume $\%$ of the AN104 pretreated waste and volume $\%$ of SBS A3 recycle in the blend. 
WSRC-TR-2004-00232, REVISION 0

SRNL-RPP-2004-00044, REVISION 0

Table 3-1. Metals in the AN104 Pretreated Waste, SBS A3 Recycle and AN104SBS3565 Pretreated Waste

\begin{tabular}{|c|c|c|c|c|}
\hline Analyte & $\begin{array}{c}\mathrm{AN}-104 \\
\text { pretreated waste } \\
\mathrm{mg} / \mathrm{L} \\
\end{array}$ & $\begin{array}{c}\text { SBS A3 } \\
\text { Recycle } \\
\text { mg/L } \\
\end{array}$ & $\begin{array}{c}\text { Analyzed } \\
\text { AN104SBS3565 } \\
\text { mg/L } \\
\end{array}$ & $\begin{array}{c}\text { Calculated } \\
\text { AN104SBS3565 } \\
\text { mg/L } \\
\end{array}$ \\
\hline \multicolumn{5}{|c|}{ ICP-Emission Spectrometry } \\
\hline $\mathrm{Ag}$ & 0.17 & NM & $<0.300$ & - \\
\hline $\mathrm{Al}$ & 13250 & 0.5 & 4575 & 4638 \\
\hline $\mathrm{B}$ & 22.85 & 292 & 192 & 198 \\
\hline $\mathrm{Ba}$ & 0.5625 & NM & $<0.300$ & - \\
\hline $\mathrm{Be}$ & 0.1795 & $<0.002$ & $<0.077$ & - \\
\hline $\mathrm{Bi}$ & NM & $<0.37$ & NM & - \\
\hline $\mathrm{Ca}$ & 1.075 & 24.9 & $<9.06$ & 17 \\
\hline $\mathrm{Cd}$ & 0.2755 & $<0.028$ & $<0.400$ & - \\
\hline $\mathrm{Ce}$ & 4.67 & NM & $<4.96$ & - \\
\hline Co & NM & $<0.088$ & NM & - \\
\hline $\mathrm{Cr}$ & 150.5 & 8.19 & 60 & 58 \\
\hline $\mathrm{Cu}$ & 0.4955 & $<0.1$ & $<0.620$ & - \\
\hline $\mathrm{Fe}$ & 0.863 & $<0.088$ & $<0.440$ & - \\
\hline Gd & 0.6205 & NM & $<0.540$ & - \\
\hline $\mathrm{K}$ & 3030 & 199 & 1250 & 1190 \\
\hline $\mathrm{La}$ & 0.664 & $<1.4$ & $<0.400$ & - \\
\hline $\mathrm{Li}$ & $<0.860$ & 48.3 & 13 & 32 \\
\hline $\mathrm{Mg}$ & $<0.106$ & 10.3 & $<1.24$ & - \\
\hline $\mathrm{Mn}$ & $<0.016$ & 0.12 & $<0.440$ & - \\
\hline Mo & 43.35 & $<0.2$ & 15 & 15 \\
\hline $\mathrm{Na}$ & 109000 & 2236 & 38500 & 39603 \\
\hline $\mathrm{Na}(\mathrm{M})$ & 4.74 & 0.097 & 1.67 & 1.7 \\
\hline $\mathrm{Nb}$ & NM & $<1$ & NM & - \\
\hline $\mathrm{Ni}$ & 3.24 & 0.145 & $<1.50$ & - \\
\hline $\mathrm{P}$ & 492 & $<1.36$ & 153 & 172 \\
\hline $\mathrm{Pb}$ & 12.45 & $<1.38$ & $<4.92$ & - \\
\hline $\operatorname{Re}$ & NM & $<0.1$ & NM & - \\
\hline $\mathrm{S}$ & 1435 & 355.5 & 739 & 733 \\
\hline $\mathrm{Sb}$ & 40.5 & NM & 14 & 14 \\
\hline $\mathrm{Si}$ & 110.5 & 12.9 & 65 & 47 \\
\hline $\mathrm{Sn}$ & 22.05 & $<0.52$ & 9 & 8 \\
\hline $\mathrm{Sr}$ & 1.63 & 0.10 & $<2.00$ & - \\
\hline $\mathrm{Ti}$ & $<0.154$ & $<0.28$ & $<0.120$ & - \\
\hline $\mathrm{U}$ & 12.75 & NM & $<15.1$ & - \\
\hline $\mathrm{V}$ & 4.80 & $<0.26$ & 1.0 & 2 \\
\hline $\mathrm{Zn}$ & 2.435 & 16.5 & 16 & 12 \\
\hline $\mathrm{Zr}$ & 1.18 & $<0.096$ & $<0.240$ & - \\
\hline \multicolumn{5}{|c|}{ Atomic Absorption } \\
\hline As & 0.664 & NM & 0.449 & - \\
\hline $\mathrm{K}$ & 2335 & NM & 928.5 & - \\
\hline $\mathrm{Na}$ & 105500 & NM & 40250 & - \\
\hline $\mathrm{Se}$ & 0.4105 & NM & 0.374 & - \\
\hline \multicolumn{5}{|c|}{ Cold Vapor Hg } \\
\hline $\mathrm{Hg}$ & $<0.110$ & NM & $<0.110$ & - \\
\hline
\end{tabular}


WSRC-TR-2004-00232, REVISION 0 SRNL-RPP-2004-00044, REVISION 0

Table 3-2. Non-metals and Radionuclides in the AN104 Pretreated Waste, SBS A3 Recycle and AN104SBS3565 Pretreated Waste

\begin{tabular}{|c|c|c|c|c|}
\hline $\begin{array}{l}\text { Non-Metal and } \\
\text { Radionuclides }\end{array}$ & $\begin{array}{c}\text { AN-104 Pretreated } \\
\text { Waste } \\
\mathrm{mg} / \mathrm{L}\end{array}$ & $\begin{array}{c}\text { SBS A3 } \\
\text { Recycle } \\
\text { mg/L }\end{array}$ & $\begin{array}{c}\text { Analyzed } \\
\text { AN104SBS3565 } \\
\mathrm{mg} / \mathrm{L}\end{array}$ & $\begin{array}{c}\text { Calculated } \\
\text { AN104SBS3565 } \\
\mathrm{mg} / \mathrm{L}\end{array}$ \\
\hline \multicolumn{5}{|c|}{ IC Anions } \\
\hline Chloride & 2850 & 3655 & 3335 & 3373 \\
\hline Fluoride & 35 & 63 & 128 & 53 \\
\hline Formate & 638 & $<100$ & 322 & 223 \\
\hline Nitrate & 67050 & 679 & 24400 & 23909 \\
\hline Nitrite & 37350 & 2165 & 16650 & 14480 \\
\hline Oxalate & 721 & 1075 & 291 & 951 \\
\hline Phosphate & 1265 & $<100$ & 320 & 443 \\
\hline Sulfate & 2700 & $<50$ & 1610 & 945 \\
\hline Total Carbon & 5760 & 330 & 2300 & 2231 \\
\hline Organic Carbon & 4010 & 12.6 & 1700 & 1412 \\
\hline Inorganic Carbon & 1750 & 317 & 600 & 819 \\
\hline Chemical Property & Mol/L & Mol/L & Mol/L & Mol/L \\
\hline Total Base & 2.43 & NM & 0.805 & - \\
\hline Free $\mathrm{OH}^{-}$ & 1.41 & NM & 0.182 & - \\
\hline Other Base excl. $\mathrm{CO}_{3}$ & 0.663 & NM & 0.273 & - \\
\hline Carbonate & 0.284 & NM & 0.116 & - \\
\hline $\mathrm{pH}$ & $\sim 14^{*}$ & 7.35 & $\sim 13.3^{*}$ & - \\
\hline Physical Property & $\mathrm{g} / \mathrm{mL}$ & $\mathrm{g} / \mathrm{mL}$ & $\mathrm{g} / \mathrm{mL}$ & - \\
\hline Specific Gravity & 1.220 & $1.02^{\dagger}$ & 1.088 & - \\
\hline Physical Property & wt.\% & wt.\% & wt.\% & wt.\% \\
\hline Suspended Solids & None visible & 0.04 & $<0.01 * *$ & 0.03 \\
\hline Total Solids & 25.8 & 0.74 & 11.6 & 9.5 \\
\hline Radionuclides & $\mu \mathrm{Ci} / \mathbf{m L}$ & $\mu \mathrm{Ci} / \mathbf{m L}$ & $\mu \mathrm{Ci} / \mathrm{mL}$ & $\mu \mathrm{Ci} / \mathbf{m L}$ \\
\hline Total Alpha & $<2.04 \mathrm{E}-04$ & NM & $<1.92 \mathrm{E}-04$ & - \\
\hline Total Beta & $1.63 \mathrm{E}-01$ & NM & $4.00 \mathrm{E}-02$ & $5.69 \mathrm{E}-02$ \\
\hline Sr-90 & $2.57 \mathrm{E}-02$ & NM & $1.07 \mathrm{E}-03$ & 8.99E-03 \\
\hline Tc-99 & $1.02 \mathrm{E}-01$ & NM & $3.60 \mathrm{E}-02$ & $3.58 \mathrm{E}-02$ \\
\hline Co-60 & - & NM & $3.67 \mathrm{E}-05$ & - \\
\hline Sb-126 & $2.40 \mathrm{E}-04$ & NM & $6.57 \mathrm{E}-05$ & $8.41 \mathrm{E}-05$ \\
\hline Sn-126 & $2.40 \mathrm{E}-04$ & NM & $6.57 \mathrm{E}-05$ & $8.41 \mathrm{E}-05$ \\
\hline Cs-137 & 4.23E-04 & NM & 8.23E-05 & $1.48 \mathrm{E}-04$ \\
\hline
\end{tabular}

$* \mathrm{pH}$ values calculated from measured free $\mathrm{OH}^{-}$

${ }^{\dagger}$ Reported in (Josephs 2003)

** Visible suspended solids in blend - See text. 
WSRC-TR-2004-00232, REVISION 0

SRNL-RPP-2004-00044, REVISION 0

Table 3-3. Metals in the AN104 Pretreated Waste, SBS A3 Recycle and AN104SBS4555 Pretreated Waste

\begin{tabular}{|c|c|c|c|c|}
\hline Analyte & $\begin{array}{c}\text { AN-104 IX } \\
\text { Effluent } \\
\text { mg/L }\end{array}$ & $\begin{array}{c}\text { SBS A3 } \\
\text { Recycle } \\
\text { mg/L }\end{array}$ & $\begin{array}{c}\text { Analyzed } \\
\text { Blend 45:55 } \\
\text { mg/L } \\
\end{array}$ & $\begin{array}{c}\text { Calculated } \\
\text { Blend 45:55 } \\
\mathrm{mg} / \mathrm{L} \\
\end{array}$ \\
\hline \multicolumn{5}{|c|}{ ICP-Emission Spectroscopy } \\
\hline $\mathrm{Ag}$ & 0.17 & NM & $<0.300$ & - \\
\hline $\mathrm{Al}$ & 13250 & 0.5 & 5900 & 5963 \\
\hline $\mathrm{B}$ & 22.85 & 292 & 164 & 171 \\
\hline $\mathrm{Ba}$ & 0.5625 & NM & $<0.300$ & - \\
\hline $\mathrm{Be}$ & 0.1795 & $<0.002$ & 0.079 & 0.081 \\
\hline $\mathrm{Bi}$ & NM & $<0.37$ & NM & - \\
\hline $\mathrm{Ca}$ & 1.075 & 24.9 & $<9.06$ & 14 \\
\hline $\mathrm{Cd}$ & 0.2755 & $<0.028$ & $<0.400$ & - \\
\hline $\mathrm{Ce}$ & 4.67 & NM & $<4.96$ & - \\
\hline Co & NM & $<0.088$ & NM & - \\
\hline $\mathrm{Cr}$ & 150.5 & 8.19 & 73 & 72 \\
\hline $\mathrm{Cu}$ & 0.4955 & $<0.1$ & $<0.620$ & - \\
\hline $\mathrm{Fe}$ & 0.863 & $<0.088$ & $<0.440$ & - \\
\hline $\mathrm{Gd}$ & 0.6205 & NM & $<0.540$ & - \\
\hline $\mathrm{K}$ & 3030 & 199 & 1645 & 1473 \\
\hline $\mathrm{La}$ & 0.664 & $<1.4$ & $<0.400$ & - \\
\hline $\mathrm{Li}$ & $<0.860$ & 48.3 & 10.05 & 27.0 \\
\hline $\mathrm{Mg}$ & $<0.106$ & 10.3 & $<1.24$ & 5.7 \\
\hline $\mathrm{Mn}$ & $<0.016$ & 0.12 & $<0.440$ & - \\
\hline Mo & 43.35 & $<0.2$ & 20 & 19.6 \\
\hline $\mathrm{Na}$ & 109000 & 2236 & 47850 & 50280 \\
\hline $\mathrm{Na}(\mathrm{M})$ & 4.74 & 0.097 & 2.08 & 2.2 \\
\hline $\mathrm{Nb}$ & NM & $<1$ & NM & - \\
\hline $\mathrm{Ni}$ & 3.24 & 0.145 & $<1.50$ & 1.5 \\
\hline $\mathrm{P}$ & 492 & $<1.36$ & 200.5 & 222 \\
\hline $\mathrm{Pb}$ & 12.45 & $<1.38$ & $<4.92$ & - \\
\hline $\mathrm{Re}$ & NM & $<0.1$ & NM & - \\
\hline $\mathrm{S}$ & 1435 & 355.5 & 818.5 & 841 \\
\hline $\mathrm{Sb}$ & 40.5 & NM & 17.45 & 18 \\
\hline $\mathrm{Si}$ & 110.5 & 12.9 & 78.05 & 57 \\
\hline $\mathrm{Sn}$ & 22.05 & $<0.52$ & 10.1 & 10 \\
\hline $\mathrm{Sr}$ & 1.63 & 0.10 & $<2.00$ & 0.8 \\
\hline $\mathrm{Ti}$ & $<0.154$ & $<0.28$ & $<0.120$ & - \\
\hline $\mathrm{U}$ & 12.75 & NM & $<15.1$ & - \\
\hline $\mathrm{V}$ & 4.80 & $<0.26$ & 1.37 & 2.3 \\
\hline $\mathrm{Zn}$ & 2.435 & 16.5 & 16.7 & 10.1 \\
\hline $\mathrm{Zr}$ & 1.18 & $<0.096$ & $<0.240$ & 0.6 \\
\hline \multicolumn{5}{|c|}{ Atomic Absorption } \\
\hline As & 0.664 & NM & - & - \\
\hline $\mathrm{K}$ & 2335 & NM & - & - \\
\hline $\mathrm{Na}$ & 105500 & NM & - & - \\
\hline $\mathrm{Se}$ & 0.4105 & NM & - & - \\
\hline \multicolumn{5}{|c|}{ Cold Vapor Hg } \\
\hline $\mathrm{Hg}$ & $<0.110$ & NM & - & - \\
\hline
\end{tabular}


Foaming was observed when the original AN-104 waste was filtered to remove entrained solids (Poirier 2003). Thus foaming of the AN-104 wastes during evaporation was considered likely, and the AN-104 pretreated waste (ion exchange effluent) was analyzed by gas chromatography/mass spectroscopy for certain organic compounds. Iminodiacetic acid (IDA) and nitrilotriacetic acid (NTA) were less than $100 \mathrm{mg} / \mathrm{L}$, and ethlyenediaminetriacetic acid $\left(\mathrm{ED}_{3} \mathrm{~A}\right)$ was not detected. Citric acid was observed in the chromatogram at a trace level but was not quantifiable. In addition, EDTA and HEDTA were both determined to be $<20$ $\mathrm{mg} / \mathrm{L}$ by an Ion Pair Chromatography method (using an HPLC instrument).

For the AN-104 pretreated waste, SBS A3 recycle, the original AN104SBS3565 pretreated waste, and concentrated AN104SBS3565 pretreated wastes, the filtrate was clear yellow and the filtered solids were brown. Both settled and mixed SBS A3 recycle are shown in Figure 3-1. Figure 3-2 shows the composite AN-104 pretreated waste (left) and the AN104SBS3565 pretreated waste after evaporation (right). The undissolved solids in both the SBS A3 recycle and the AN104SBS3565 pretreated waste settled to the bottom of their vessels. Suspended solids settling information for the AN104SBS3565 pretreated wastes are presented in section 4.4.2.

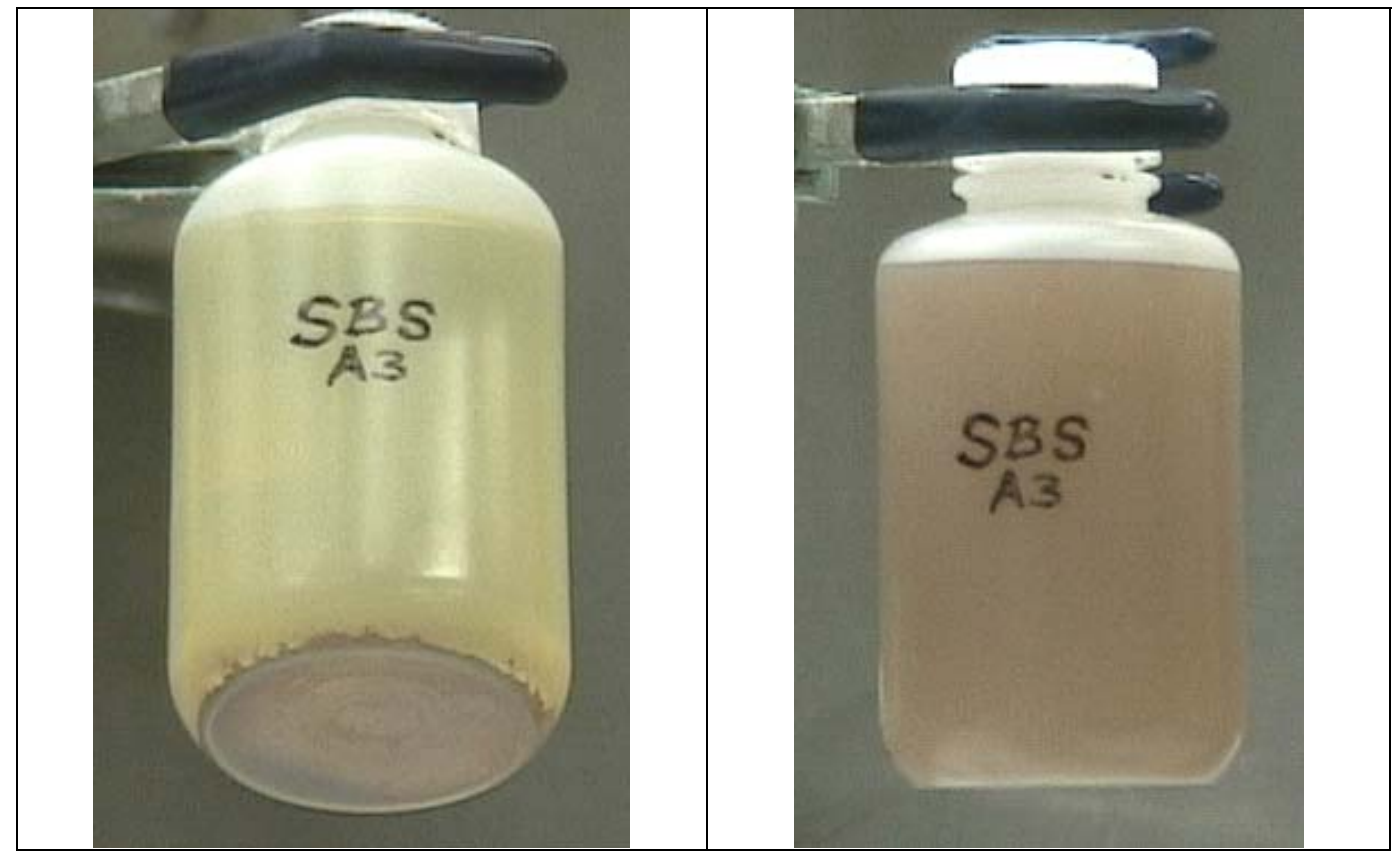

Figure 3-1. Settled and Mixed Solutions of Simulant SBS A3 Recycle 
WSRC-TR-2004-00232, REVISION 0

SRNL-RPP-2004-00044, REVISION 0

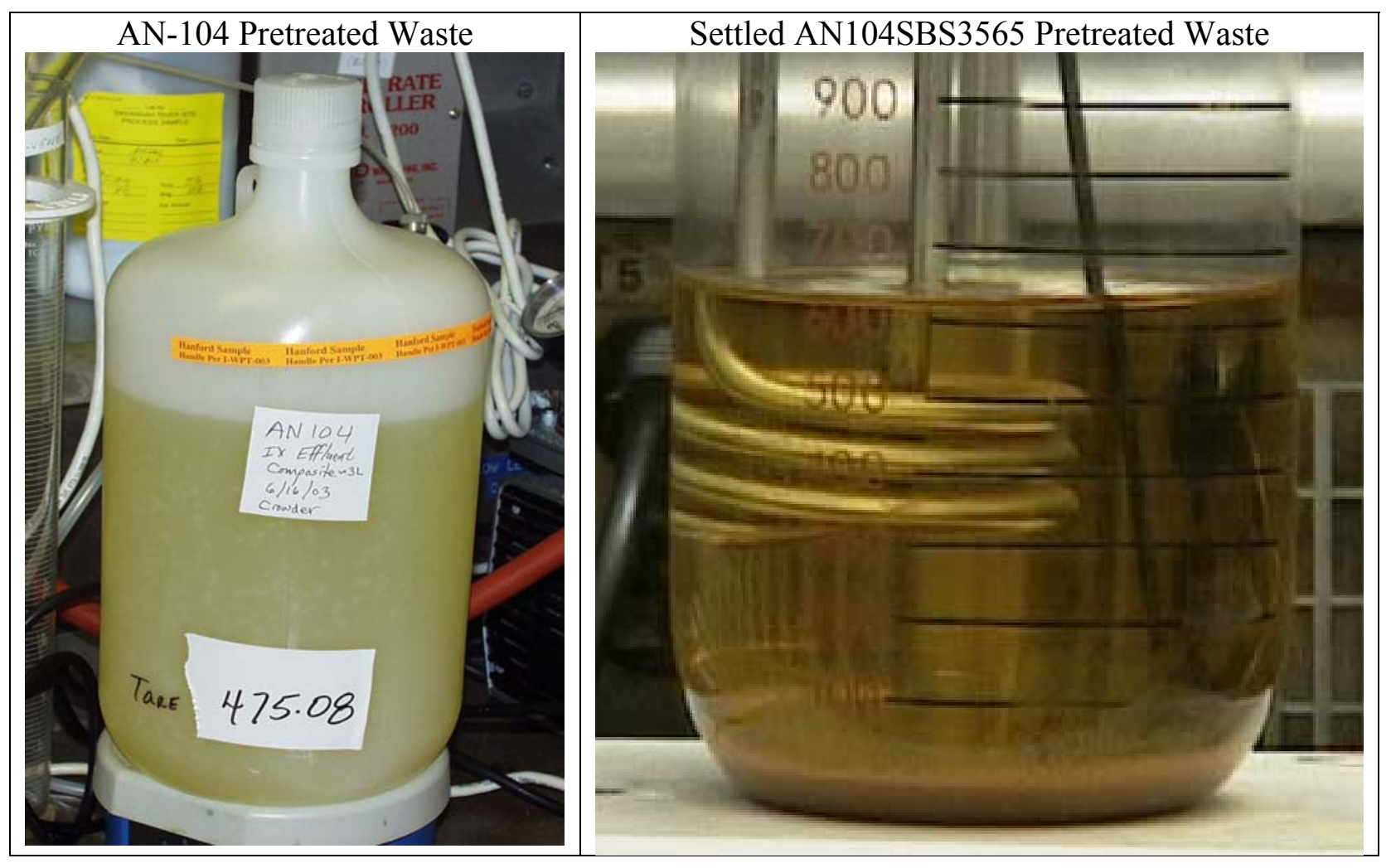

Figure 3-2. AN-104 Pretreated Waste and Settled AN104SBS3565 Pretreated Waste

\subsubsection{System Configuration}

Figure 3-3 shows the experimental setup to evaporate the initial AN104SBS3565 pretreated waste to a sodium concentration of $4.7 \mathrm{M}$. The evaporator, condenser, and condensate collection vessel were fabricated at the SRNL Glass Shop. The evaporator has a nominal 4 inch inside diameter and is 20 inches tall, with a working volume of $3000 \mathrm{~mL}$ for foaming tests. The evaporator body was a thick-walled borosilicate glass and the lid had multiple entry ports. A Corning stirrer/hot plate was used for warming up the sample and for baseline heat. During the evaporation runs, most of the heat was supplied via an immersed heating coil. The initial AN104SBS3565 pretreated waste was drawn into the evaporator by the vacuum in the system and was added periodically to maintain a liquid level between 700 and $1500 \mathrm{~mL}$. The final liquid level dropped below $700 \mathrm{~mL}$ at the end of each experiment as the final concentrate volume decreased to reach the final targeted sodium molarity. 


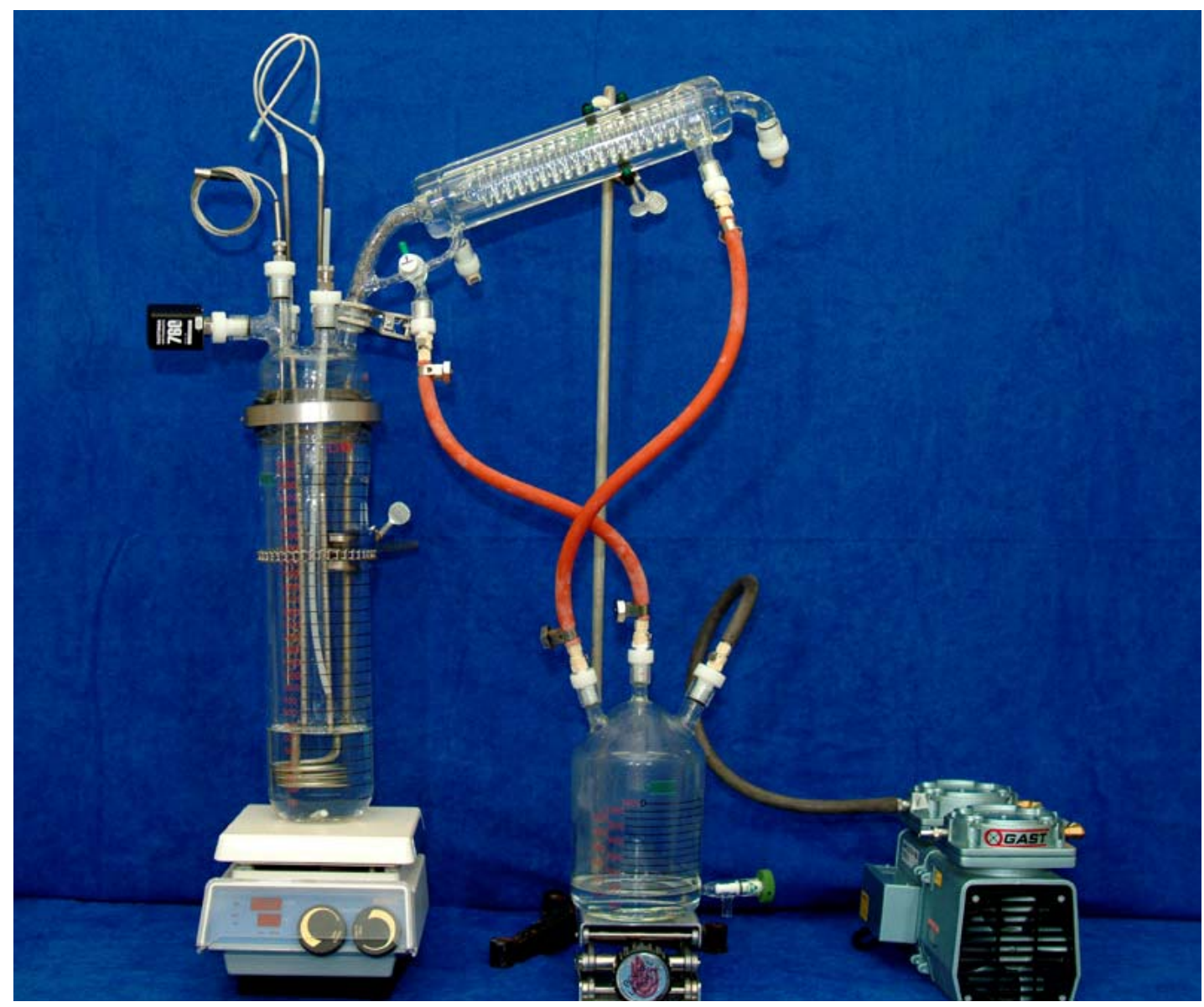

Figure 3-3. Evaporator Apparatus

The evaporator temperature was monitored using a Cole-Parmer Type $\mathrm{K}$ thermocouple and thermocouple readout (model 91100-50). The evaporator pressure was initially measured using a calibrated SPER Scientific pressure transducer (model PS100) and readout (model 840065).

After a six-week break in evaporation testing while the initial evaporated AN104SBS3565 pretreated waste was undergoing characterization, suspect boiling point readings (pressure and corresponding temperature) were observed that involved significantly lower boiling temperatures when compared to results of similar solutions. Subsequent checkout of both the calibrated thermocouple and pressure transducer indicated that the pressure transducer readings were consistently biased high. This is likely due to the prolonged period of contact that the pressure transducer had with the caustic solution vapors over the six-week static period. The problem was corrected by replacing the pressure equipment with a DTC Instruments transducer (model PTA30AB) and readout (model SCI-10).

All instruments used to measure temperature and pressure were calibrated with NISTtraceable standards prior to use by the Savannah River Standards Laboratory and logged as Measuring and Test Equipment (M\&TE). All pressure data reported were measured using pressure transducers that were checked against M\&TE instruments prior to use. In the case of the faulty pressure transducer, none of these data is reported in this report and the portion 
of the experiment conducted was repeated using a new pressure transducer that was calibrated using M\&TE instrumentation.

Vacuum in the evaporator was provided by a vacuum pump (Vacuubrand MZ 2C Pump, using a Teflon ${ }^{\circledR}$ diaphragm pump). The tubing between the evaporator and the vacuum pump was equipped with an air bleed valve to control evaporator pressure.

The jacketed condenser used was approximately 3 inches in diameter, and was cooled using a Neslab Coolflow DC-25 chiller, operated at nominally 5 to $10^{\circ} \mathrm{C}$. The condenser was equipped with a 3-way valve which allowed switching between reflux and condensate collection. The condensate collection vessel had graduations up to $1400 \mathrm{~mL}$ and a drainage spout.

Samples of the AN104 pretreated waste, SBS A3 recycle, and various sodium concentrations of the AN104SBS pretreated wastes required filtering for analysis of the filtrate and/or the solids. Small samples were filtered using Gelman Acrodisc $25 \mathrm{~mm}$ syringe filters with $0.45 \mu \mathrm{m}$ Versapor Membrane. Large samples and all samples requiring solids analysis were vacuum-filtered using Nalgene cellulose nitrate filters, $47 \mathrm{~mm}$ diameter, and $0.45 \mu \mathrm{m}$ pore diameter.

Duplicate AN104SBS3565 pretreated waste samples were taken at approximately $6 \mathrm{M} \mathrm{Na}$. A portion of each sample was submitted for density, suspended solids, and total solids. Filtrate samples were analyzed for cations (using inductively coupled plasma emissions spectroscopy - ICPES), anions (using ion chromatography - IC), hydroxide/base content, and carbon content. In addition, insoluble solids were analyzed using x-ray diffraction (XRD) and, in some cases, scanning electron microscopy (SEM).

\subsection{RESULTS AND DISCUSSION}

\subsubsection{Experimental Observations}

For most of this study, the AN104SBS3565 pretreated waste (i.e., 2.0 L of pretreated AN104 and 3.7 L of SBS A3) was used. Initial evaporation testing did not include any antifoam addition so that any foaming of the AN104SBS3565 pretreated waste could be observed. The first notable observation was that as soon as boiling began, a foam with small bubbles rose rapidly in the evaporator to about $100 \%$ of the liquid height. After about 10 seconds, this foam subsided. This occurred at a very low flux $\left(\mathrm{gpm} / \mathrm{ft}^{2}\right)$ or evaporation rate $(\mathrm{lbm} / \mathrm{min})$. This phenomenon was observed at other times after fresh feed was added to the evaporator. Since the evaporator is operated under vacuum, this type of foaming could be attributed to the degassing of the solution. No Dow Q2-3138a antifoam was present when this foaming occurred. Later, foam with larger bubbles was observed, and was captured on video (Crowder 2004). This latter foam increased in height with increased evaporation rate or flux, even with $100 \mathrm{mg} / \mathrm{L}$ antifoam present, as seen in Figure 3-4 for the 3.7 M Na AN104SBS3565 pretreated waste. Antifoam performance is also compared in Table 3-4 for both the AN104SBS3565 and AN104SBS4555 pretreated wastes for different operating 
conditions and sodium molarities. The Dow Q2-3138a antifoam was selected for this study based on results in an earlier study using LAW waste simulants (Baich 2003). The design flux basis, $0.226 \mathrm{gpm} / \mathrm{ft}^{2}$, is described in Table A-14 of the simulant study (Baich 2003).

Foaminess is reported as a percent of liquid height at the time of foaming, as directed in the Test Specification. Foam height fluctuates, so foaminess is typically reported as an average between the highest and lowest foam heights consistently observed. An occasional spike or burst of a small amount of material was not included in the determination of average foam height. It should be noted that the variation in foam height is highest at the low flux rates. For example, at $4 \%$ of design flux with no antifoam, foam height fluctuated from 4 to $220 \%$ of liquid height. Because the height of the experimental apparatus used, foaminess greater than $220 \%$ of liquid height was difficult to accurately measure. Hence, a small amount of antifoam was added. As flux increased, the variation in foam height lessened. At $20 \%$ of design flux with $100 \mathrm{mg} / \mathrm{L}$ antifoam, foaminess varied from 60 to $110 \%$ of liquid height. These observations are included in Table 3-4 and Figure 3-4, and show that antifoam addition reduces total foaminess as well as the variation.

To summarize, the evaporation/antifoam tests with AN104SBS3565 and AN104SBS4555 pretreated wastes, nominally 400 to $900 \mathrm{mg} / \mathrm{L}$ of antifoam (Dow Q2-3138a) were effective at reducing foam from over $100 \%$ of liquid height to 20 to $40 \%$ or no visible foam. However, occasional spikes of material over $20 \%$ of liquid height were still observed during vigorous boiling. In one case, for AN104SBS4555 pretreated waste, the antifoam was still effective after 6 days. However for the AN104SBS3565 pretreated waste, after 6 weeks the average foam height had increased from about $20 \%$ to about $50 \%$ of liquid height. (Note: The 6-day and 6-week hold times involved maintaining the solution in the concentrate pot at room temperature and atmospheric pressure.).

Table 3-4. Antifoam Performance at Different Conditions For AN104SBS Pretreated Wastes

\begin{tabular}{|c|c|c|c|c|c|c|}
\hline $\begin{array}{c}\text { Flux } \\
\text { \% of design } \\
\left(\mathbf{0 . 2 2 6} \mathbf{g p m} / \mathbf{f t}^{2} \mathbf{)}\right.\end{array}$ & $\begin{array}{c}\text { Flux } \\
\mathbf{g p m} / \mathbf{f t}^{2}\end{array}$ & Pretreated Feed & $\begin{array}{c}\text { Sodium } \\
\text { Molarity }\end{array}$ & $\begin{array}{c}\text { Antifoam } \\
\mathbf{m g} / \mathbf{L}\end{array}$ & $\begin{array}{c}\text { Foaminess } \\
\text { \% liquid } \\
\text { height }\end{array}$ & Comments \\
\hline 9 & 0.023 & AN104SBS3565 & $2.0^{*}$ & 0 & $230-280$ & - \\
\hline 4 & 0.009 & AN104SBS3565 & $3.9^{*}$ & 0 & $4-220$ & - \\
\hline 4 & 0.009 & AN104SBS3565 & $3.9^{*}$ & 100 & $60-110$ & - \\
\hline 13 & 0.029 & AN104SBS3565 & 4.7 & 430 & 16 & $\begin{array}{c}\text { Spikes to 50\% } \\
\text { liquid height } \\
\text { observed. }\end{array}$ \\
\hline 20 & 0.046 & AN104SBS3565 & $4.7^{*}$ & 430 & 30 & - \\
\hline 20 & 0.046 & AN104SBS3565 & $8.1^{*}$ & 910 & 38 & - \\
\hline 20 & 0.046 & AN104SBS4555 & 6.4 & 0 & 280 & - \\
\hline 20 & 0.046 & AN104SBS4555 & 6.4 & 725 & 50 & $\begin{array}{c}\text { No bubbles } \\
\text { observed. }\end{array}$ \\
\hline
\end{tabular}

*Estimated from starting feed sodium concentration and liquid levels in concentrate pot - not measured analytically. 
WSRC-TR-2004-00232, REVISION 0

SRNL-RPP-2004-00044, REVISION 0

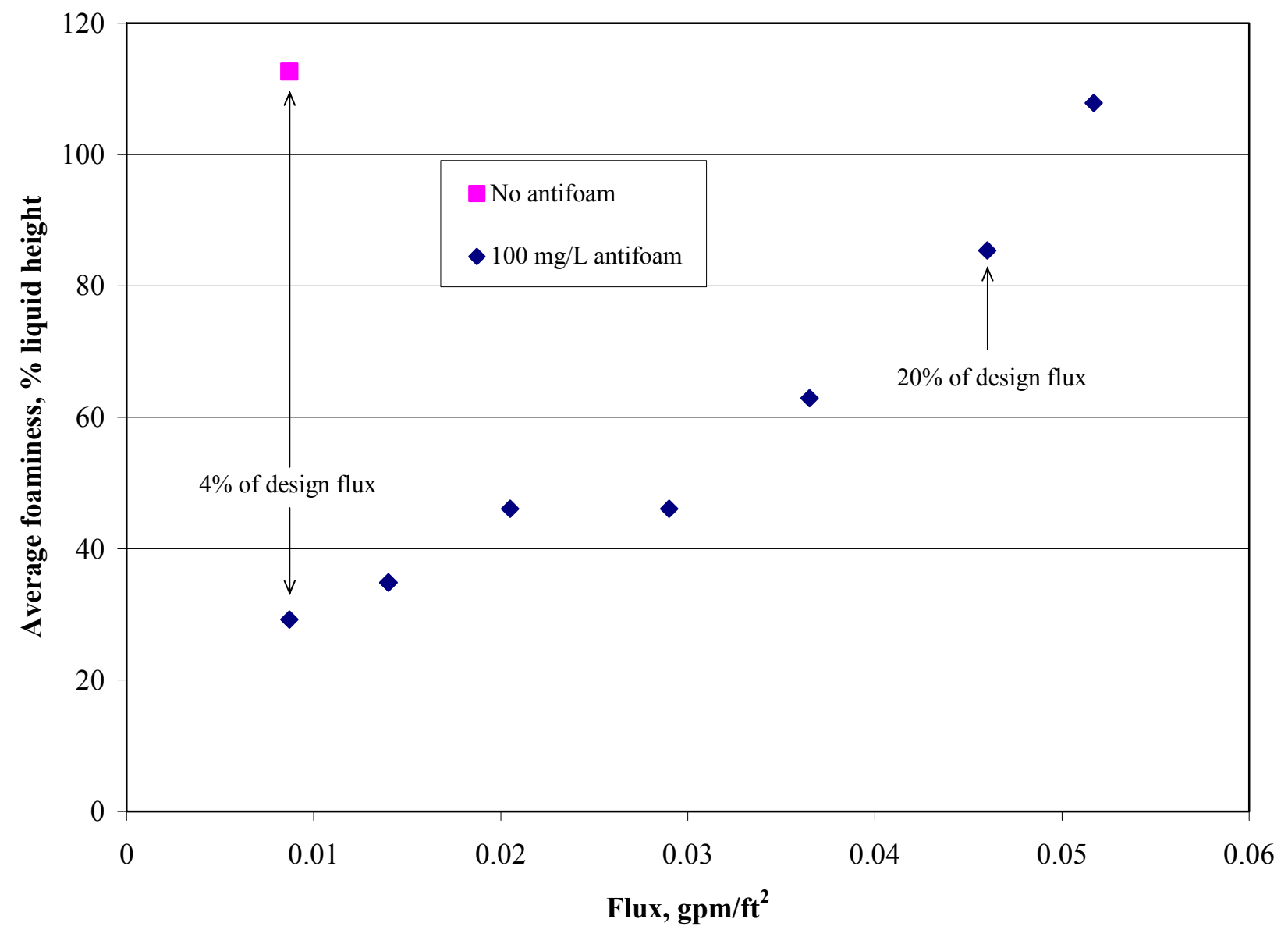

Figure 3-4. Foaminess of 3.9 M Na AN104SBS3565 Pretreated Feed

\subsubsection{Boiling Point}

As mentioned previously, boiling points were measured for a range of sodium concentrations and pressures. In addition, boiling points were estimated using a model of the treated feed evaporator process built with the OLI Environmental Simulation Program (OLI/ESP) version 6.6 using the CARBONAT, HNO3DB, SILICA, and ZEOLITE private databases, along with the public database. These databases were developed and validated in prior work (Barnes 2003). Figure 3-5 shows a schematic of the OLI treated feed evaporator model.

The compositions of the AN-104 pretreated waste and SBS A3 recycle streams used in OLI were derived by charge balancing the cation (Table 3-1) and anion (Table 3-2) elemental analyses of the two streams. In previous work with SBS recycle modeling (Crowder 2003), the analyzed SBS A3 recycle anion compositions had to be reduced by $60 \%$ in order to charge balance the stream. All anions concentrations shown in Table 3-2 for the SBS A3 recycle were reduced by $60 \%$. The AN-104 pretreated feed cations and anions balanced with no significant alterations needed to either data set. The discrepancy with the SBS A3 recycle 
WSRC-TR-2004-00232, REVISION 0

SRNL-RPP-2004-00044, REVISION 0

is most likely due to inflated, or high-bias analytical values for the anions like halides, nitrates and/or nitrites. To generate the boiling point data, the OLI model was run for both the AN104SBS3565 and AN104SBS4555 pretreated wastes, at evaporator bottoms sodium concentrations of 5.0,6.0, and $8.0 \mathrm{M}$, and evaporator pressures of 60,70 , and $80 \mathrm{~mm} \mathrm{Hg}$.

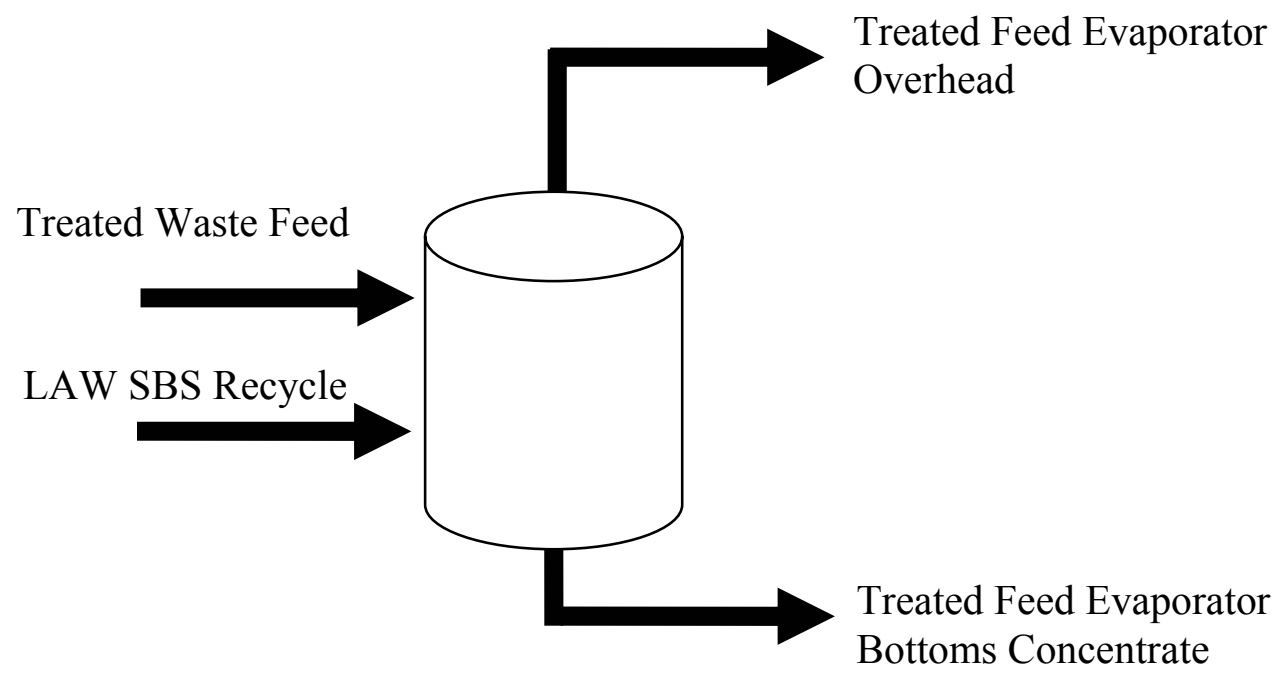

Figure 3-5. OLI Treated Feed Evaporator Model

The model predicted boiling points are presented in Figure 3-6 and Figure 3-7. As seen in Figure 3-6 and Figure 3-7, the experimental boiling points are nominally 2 to $4{ }^{\circ} \mathrm{C}$ higher than the model predicted boiling points. One reason for the offset between experimental and model results is partially due to the reduction of the anion content for the SBS A3 recycle stream (metals and anions data shown in Table 3-1 and Table 3-2) in order to charge balance the stream for the OLI model. The OLI model also assumes perfect conditions of constant exit $\mathrm{Na}$ molarity, evaporator temperature and pressure which are impossible to duplicate in a real experiment. Another factor is that the databases used in the OLI model have not been optimized for vapor pressure calculation but for electrolyte chemistry. The underestimation of the boiling point was also seen in prior work (Crowder 2003). The slope of the boiling point in Figure 3-6 and Figure 3-7 agrees between the model and experimental data, so further investigation could help resolve this slight difference in boiling point. For the AN104SBS4555 pretreated waste, experimental boiling points are only reported for the final concentration $(6.4 \mathrm{M} \mathrm{Na})$. The system was set to reflux (to maintain concentration) and the data were measured on separate days and included in Figure 3-7. The ' 1 ' and '2' denote the different sampling days. Comparison of Figure 3-6 and Figure 3-7 indicate that experimental data for the AN104SBS4555 pretreated feed are similar to those for the AN014SBS3565 pretreated feed. The modeling data for the two different blends were also similar. This comparison shows that there were no significant differences in concentrating the AN104SBS 
WSRC-TR-2004-00232, REVISION 0

SRNL-RPP-2004-00044, REVISION 0

pretreated waste for the two different blend ratios. The boiling points in the current study are comparable to those in a study of Envelope A simulants (Josephs 2003).

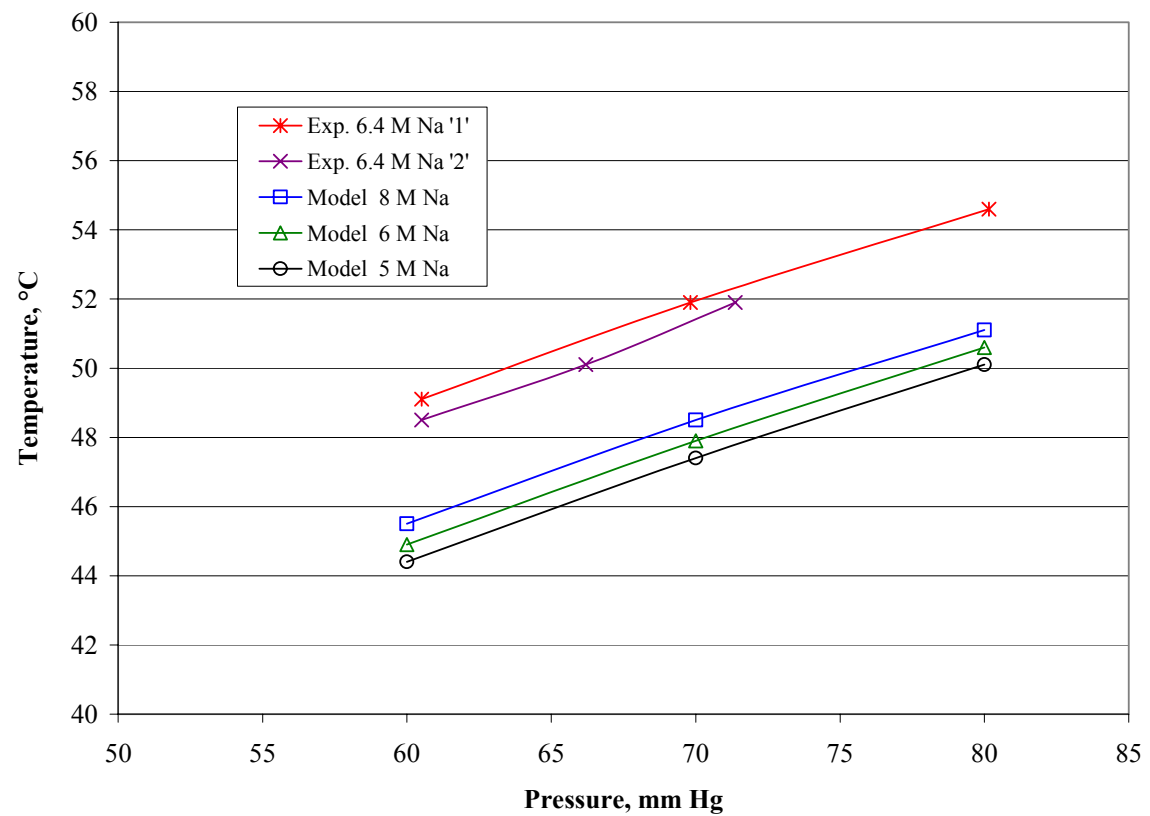

Figure 3-6. Experimental and Model Boiling Points for AN104SBS3565 Pretreated Waste

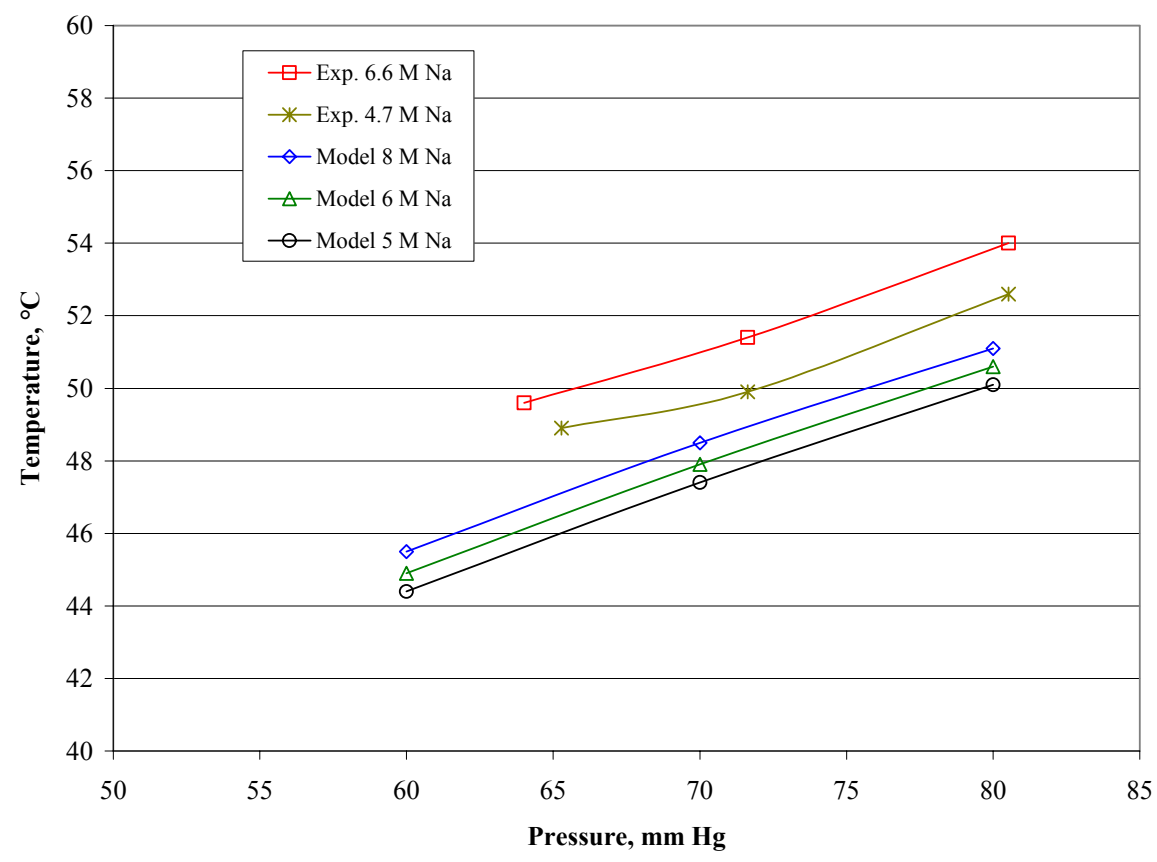

Figure 3-7. Experimental and Model Boiling Points for AN104SBS4555 Pretreated Waste 


\subsubsection{Product Composition}

The initial objectives specified in the Test Specification for evaporator concentration endpoints were given as nominally 6,8 and 10 molar sodium. However as the TTP evolved and melter studies were performed at VSL (Matlock 2003) and GTS Duratek (Duratek 2003), this concentration endpoint for the evaporator concentrate was targeted per WTP direction (as approved by the TTP) at $6 \mathrm{M}$ sodium with the upper and lower targets set at $\pm 15 \%$ of the $6 \mathrm{M}$ target, respectively, which is representative of the pilot scale testing conducted by Duratek. Therefore, no solubility results are reported for this task.

The AN104SBS3565 pretreated waste was concentrated to a target of $6 \mathrm{M}$ sodium and both the concentrate and condensate were analyzed in duplicate. Table 3-5, Table 3-6, and Table 3-7 show the averaged data. The actual concentration endpoint was determined to be lower than target, i.e., sodium measured was $4.74 \mathrm{M}$ versus the target of $6 \mathrm{M}$. After discovering the low sodium concentration, the concentrate sample, which had set static in the concentrate pot for approximately six weeks, was further evaporated to the target of $6 \mathrm{M} \mathrm{Na}$. The final AN104SBS3565 pretreated waste was concentrated to $7.29 \mathrm{M} \mathrm{Na}$, which overshot the $6 \mathrm{M}$ $\mathrm{Na}$ target. The characterization of this $7.29 \mathrm{M} \mathrm{Na}$ AN104SBS3565 pretreated waste is presented in the rheology and physical properties section 4.0 in this report.

The characterization data in Table 3-5, Table 3-6, and Table 3-7 were the data used by WTP for developing the glass formulation for the AN104SBS3565 pretreated waste. The $4.74 \mathrm{M}$ and 7.29 M Na waste contained visible suspended solids. However, the data in Table 3-6 shows that only one of the duplicate samples had measurable suspended solids at $0.79 \mathrm{wt} \%$. The other duplicate measured value was $<0.1 \mathrm{wt} \%$. It is likely that the 'less than' duplicate value was derived from sampling of the supernatant-rich portion of the concentrate sample after solids had settled out to the bottom of the sample. The solids characterization data discussed below in Section 3.2.4 was also transmitted to WTP for use in the AN-104 LAW glass formulation development.

In this study, the concentration factor $(\mathrm{CF})$ is defined as the concentration in the concentrate (Table 3-5) divided by that of the feed (Table 3-1). Table 3-5 shows certain CF for the measured metals. The average $\mathrm{CF}$ for this evaporation was $3.2 \pm 0.5$. The decontamination factor (DF) is the concentration in the feed (Table 3-1) divided by that of the condensate from evaporation (Table 3-5). The DF calculated for aluminum is greater than $1.5 \mathrm{E} 4$ and the DF calculated for sodium is 8.1E4. These two DF's are thought to be the most accurate representation of the actual DF for this evaporator since the Cs DF is based upon analytical results that are below detection. Use of other data in Table 3-1 and Table 3-5, i.e., the analytes with relatively low concentrations in the feed (Table 3-1), give much lower computed DF's. Table 3-5 and Table 3-6 show measurable amounts of sodium and silicon and free hydroxide were determined in the condensate, indicating some degree of dissolution of $\mathrm{Si}$ in the caustic AN104SBS3565 evaporation products. 
WSRC-TR-2004-00232, REVISION 0

SRNL-RPP-2004-00044, REVISION 0

Table 3-5. Metals Products, CF and DF from Evaporation of AN104SBS3565 Pretreated Waste

\begin{tabular}{|c|c|c|c|c|}
\hline Analyte & $\begin{array}{c}\text { Concentrate } \\
\mathrm{mg} / \mathrm{L}\end{array}$ & $\begin{array}{c}\text { Concentration } \\
\text { factor }\end{array}$ & $\begin{array}{c}\text { Condensate } \\
\mathrm{mg} / \mathrm{L}\end{array}$ & $\begin{array}{l}\text { Decontamination } \\
\text { factor }\end{array}$ \\
\hline $\mathrm{Ag}$ & 0.404 & - & $<0.030$ & - \\
\hline $\mathrm{Al}$ & 17400 & 3.8 & $<0.310$ & $>1.5 \mathrm{E} 4$ \\
\hline $\mathrm{B}$ & 611 & 3.2 & $<3.24$ & - \\
\hline $\mathrm{Ba}$ & 0.3845 & - & $<0.030$ & - \\
\hline $\mathrm{Be}$ & 0.1085 & - & $<0.001$ & - \\
\hline $\mathrm{Ca}$ & 5.695 & - & $<0.906$ & - \\
\hline $\mathrm{Cd}$ & 0.348 & - & $<0.040$ & - \\
\hline $\mathrm{Ce}$ & 4.745 & - & $<0.496$ & - \\
\hline $\mathrm{Cr}$ & 166.5 & 2.8 & $<0.034$ & - \\
\hline $\mathrm{Cu}$ & 0.8045 & - & $<0.062$ & - \\
\hline $\mathrm{Fe}$ & $<0.220$ & - & $<0.044$ & - \\
\hline $\mathrm{Gd}$ & 0.5855 & - & $<0.054$ & - \\
\hline $\mathrm{K}$ & 5170 & 4.1 & $<19.0$ & - \\
\hline $\mathrm{La}$ & 0.7275 & - & $<0.040$ & - \\
\hline $\mathrm{Li}$ & 2.34 & - & $<0.170$ & - \\
\hline $\mathrm{Mg}$ & $<0.62$ & - & $<0.124$ & - \\
\hline $\mathrm{Mn}$ & $<0.220$ & & $<0.044$ & - \\
\hline Mo & 51.05 & 3.3 & $<0.408$ & - \\
\hline $\mathrm{Na}$ & 109000 & 2.8 & 0.475 & $8.1 \mathrm{E} 4$ \\
\hline $\mathrm{Na}(\mathrm{M})$ & 4.74 & - & $2.07 \mathrm{E}-05$ & - \\
\hline $\mathrm{Ni}$ & 2.785 & - & $<0.150$ & - \\
\hline $\mathrm{P}$ & 433 & 2.8 & $<0.970$ & - \\
\hline $\mathrm{Pb}$ & 2.87 & - & $<0.492$ & - \\
\hline $\mathrm{S}$ & 2510 & 3.4 & $<0.764$ & - \\
\hline $\mathrm{Sb}$ & 39.9 & 2.9 & $<0.302$ & - \\
\hline $\mathrm{Si}$ & 191 & 2.9 & 8.475 & 22 \\
\hline $\mathrm{Sn}$ & 23.35 & 2.7 & $<0.490$ & - \\
\hline $\mathrm{Sr}$ & 2.065 & - & $<0.200$ & - \\
\hline $\mathrm{Ti}$ & $<0.060$ & - & $<0.012$ & - \\
\hline $\mathrm{U}$ & 10.45 & - & $<1.51$ & - \\
\hline $\mathrm{V}$ & 4.46 & - & $<0.022$ & - \\
\hline $\mathrm{Zn}$ & 56.85 & 3.6 & $<0.110$ & - \\
\hline $\mathrm{Zr}$ & 0.5875 & - & $<0.024$ & - \\
\hline
\end{tabular}


WSRC-TR-2004-00232, REVISION 0

SRNL-RPP-2004-00044, REVISION 0

Table 3-6. Anions and Other Evaporation Products of the AN104SBS3565 Pretreated Waste

\begin{tabular}{|c|c|c|}
\hline & \multirow{3}{*}{$\begin{array}{c}\text { Pretreated Waste } \\
\mathrm{mg} / \mathrm{L}\end{array}$} & \multirow{3}{*}{$\begin{array}{c}\text { Condensate } \\
\mathrm{mg} / \mathrm{L}\end{array}$} \\
\hline & & \\
\hline & & \\
\hline \multicolumn{3}{|c|}{ Ion Chromatography: Anions } \\
\hline Chloride & 7545 & $<20$ \\
\hline Fluoride & 145 & $<20$ \\
\hline Formate & 1100 & $<100$ \\
\hline Nitrate & 53900 & $<100$ \\
\hline Nitrite & 37350 & $<100$ \\
\hline Oxalate & 1095 & $<100$ \\
\hline Phosphate & 1425 & $<100$ \\
\hline Sulfate & 3375 & $<50$ \\
\hline \multicolumn{3}{|c|}{ Ion Exclusion Chromatography: Organic Anions } \\
\hline Organic & $\mathrm{mg} / \mathrm{L}$ & $\mathrm{mg} / \mathrm{L}$ \\
\hline Acetate & 735 & $<10$ \\
\hline Citrate & 400 & $<10$ \\
\hline Glycolate & 212 & $<10$ \\
\hline Total Carbon & 6980 & 47.1 \\
\hline Inorganic Carbon & 3815 & 8.5 \\
\hline Organic Carbon & 3170 & 38.5 \\
\hline Others & $\mathrm{M}$ & $\mathrm{M}$ \\
\hline $\mathrm{pH}$ & - & 10.0 \\
\hline Total Base & 2.46 & - \\
\hline Free $\mathrm{OH}$ & 1.08 & - \\
\hline Other base excl. CO3 & 0.819 & - \\
\hline Solids & wt. $\%$ & wt. $\%$ \\
\hline Total Solids & 31.8 & NM \\
\hline Suspended Solids* & 0.79 & NM \\
\hline Others & $\mathrm{g} / \mathrm{mL}$ & $\mathrm{g} / \mathrm{mL}$ \\
\hline Specific Gravity & 1.283 & 1.00 \\
\hline
\end{tabular}

*Solids were visible in the sample.

NM - Not Measured 
WSRC-TR-2004-00232, REVISION 0

SRNL-RPP-2004-00044, REVISION 0

Table 3-7. Comparison of AN104SBS3565 Pretreated Waste Evaporator Solutions by Gamma Pulse Height Analysis

\begin{tabular}{|c|c|c|c|c|c|}
\hline Analyte & $\boldsymbol{\mu} \mathbf{C i} / \mathbf{m L}$ & $\begin{array}{c}\text { Concentrate } \\
\boldsymbol{\mu} \mathbf{C i} / \mathbf{m L}\end{array}$ & $\begin{array}{c}\text { Concentration } \\
\text { Factor }\end{array}$ & $\begin{array}{c}\text { Condensate } \\
\boldsymbol{\mu} \mathbf{C i} / \mathbf{m L}\end{array}$ & $\begin{array}{c}\text { Decontamination } \\
\text { Factor }\end{array}$ \\
\hline $\mathrm{Co}-60$ & $3.67 \mathrm{E}-05$ & $8.52 \mathrm{E}-05$ & 2.3 & $<4.35 \mathrm{E}-06$ & $>8.5$ \\
\hline $\mathrm{Sb}-126$ & $6.57 \mathrm{E}-05$ & $1.88 \mathrm{E}-04$ & 2.9 & $<4.14 \mathrm{E}-06$ & $>15.9$ \\
\hline $\mathrm{Sn}-126$ & $6.57 \mathrm{E}-05$ & $2.81 \mathrm{E}-04$ & 4.3 & $<7.74 \mathrm{E}-06$ & $>8.5$ \\
\hline $\mathrm{Cs}-137$ & $8.23 \mathrm{E}-05$ & $2.82 \mathrm{E}-04$ & 3.4 & $<6.51 \mathrm{E}-06$ & $>12.6$ \\
\hline
\end{tabular}

After the AN104SBS3565 pretreated waste had been evaporated and the products sent for analytical characterization, a separate evaporation test was completed on the AN104SBS54555 pretreated waste. The AN104SBS4555 pretreated waste was concentrated to target $6 \mathrm{M}$ sodium and the concentrate was analyzed for metals only, to confirm the $6 \mathrm{M}$ $\mathrm{Na}$ endpoint was met. Table 3-8 shows the analytical data from the final AN104SBS4555 pretreated waste, ending with a $6.4 \mathrm{M} \mathrm{Na}$ solution, which is within $10 \%$ of the target of $6 \mathrm{M}$ Na. The calculated starting AN104SBS4555 pretreated waste is also shown in Table 3-8, along with the concentration factors derived from dividing the analyzed concentrate waste values by the calculated starting waste values. For components present at greater than 100 $\mathrm{mg} / \mathrm{L}$, the $\mathrm{CF}$ was 3.2 . 
WSRC-TR-2004-00232, REVISION 0

SRNL-RPP-2004-00044, REVISION 0

Table 3-8. Metal Products of Starting and Final AN104SBS4555 Pretreated Waste

\begin{tabular}{|c|c|c|c|}
\hline \multirow[t]{2}{*}{ Analyte } & $\begin{array}{l}\text { Calculated Starting } \\
\text { Pretreated Waste }\end{array}$ & $\begin{array}{c}\text { Analyzed Final } \\
\text { Pretreated Waste }\end{array}$ & \multirow{2}{*}{$\begin{array}{c}\text { Contamination } \\
\text { Factor }\end{array}$} \\
\hline & $\mathrm{mg} / \mathrm{L}$ & $\mathrm{mg} / \mathrm{L}$ & \\
\hline $\mathrm{Ag}$ & - & 0.476 & - \\
\hline $\mathrm{Al}$ & 5962.8 & 19000 & 3.2 \\
\hline $\mathrm{B}$ & 170.9 & 540 & 3.2 \\
\hline $\mathrm{Ba}$ & 0.3 & 0.837 & - \\
\hline $\mathrm{Ca}$ & 14.2 & 85.5 & 6.0 \\
\hline $\mathrm{Cd}$ & 0.1 & 0.572 & - \\
\hline $\mathrm{Ce}$ & 2.1 & 8.11 & 3.9 \\
\hline $\mathrm{Cr}$ & 72.2 & 217 & 3.0 \\
\hline $\mathrm{Cu}$ & 0.3 & 0.917 & - \\
\hline $\mathrm{Fe}$ & 0.4 & 17.9 & - \\
\hline $\mathrm{Gd}$ & 0.3 & 0.845 & - \\
\hline $\mathrm{K}$ & 1473.0 & 5960 & 4.0 \\
\hline $\mathrm{La}$ & 1.1 & 1.11 & - \\
\hline $\mathrm{Li}$ & 27.0 & 46.1 & 1.7 \\
\hline $\mathrm{Mg}$ & 5.7 & 9.03 & - \\
\hline $\mathrm{Mn}$ & 0.1 & 0.136 & - \\
\hline Mo & 19.6 & 59.8 & 3.0 \\
\hline $\mathrm{Na}$ & 50279.5 & 148000 & 2.9 \\
\hline $\mathrm{Na}(\mathrm{M})$ & 2.2 & 6.4 & 2.9 \\
\hline $\mathrm{Ni}$ & 1.5 & 4.23 & - \\
\hline $\mathrm{P}$ & 222.1 & 587 & 2.6 \\
\hline $\mathrm{Pb}$ & 6.4 & 17.2 & - \\
\hline $\mathrm{S}$ & 841.3 & 2620 & 3.1 \\
\hline $\mathrm{Sb}$ & 18.2 & 51.7 & 2.8 \\
\hline $\mathrm{Si}$ & 56.8 & 284 & 5.0 \\
\hline $\mathrm{Sn}$ & 10.2 & 29.5 & 2.9 \\
\hline $\mathrm{Sr}$ & 0.8 & 22.9 & - \\
\hline $\mathrm{Ti}$ & 0.2 & 9.43 & - \\
\hline $\mathrm{U}$ & 5.7 & 19.7 & - \\
\hline $\mathrm{V}$ & 2.3 & 5.82 & - \\
\hline $\mathrm{Zn}$ & 10.1 & $\begin{array}{l}54.0 \\
\end{array}$ & 5.3 \\
\hline $\mathrm{Zr}$ & 0.6 & 6.83 & - \\
\hline
\end{tabular}




\subsubsection{Solids}

The solids found in SBS A3 recycle had a nominal particle size range of 1 to $20 \mu \mathrm{m}$. About $87 \%$ of the particles were between 1 and $8 \mu \mathrm{m}$. Only $5.7 \%$ of the particles were less than $0.97 \mu \mathrm{m}$. Detailed particle size distribution results are included in Appendix A. The SBS A3 recycle solids were identified by $\mathrm{x}$-ray diffraction (XRD). The most prevalent solid was quartz $\left(\mathrm{SiO}_{2}\right)$. Other solids found, in decreasing order of prevalence, were $\mathrm{Fe}_{2} \mathrm{O}_{3}, \mathrm{TiO}_{2}$, $\mathrm{ZrSiO}_{4}, \mathrm{Al}_{2} \mathrm{O}_{3}, \mathrm{NaF} \bullet 1.5\left(\mathrm{CaF}_{2}\right) \bullet \mathrm{AlF}_{3}, \mathrm{NaNO}_{3}, \mathrm{CaF}_{2}$, and $\mathrm{NaMgAlF}_{6} \cdot \mathrm{H}_{2} \mathrm{O}$. A sample of filtered SBS A3 recycle solids was digested by cesium hydroxide fusion and dissolved in hydrochloric acid. The resulting solution was analyzed by ICP-Emission Spectroscopy. A filtered sample of the concentrated solids from the AN104SBS3565 pretreated waste was also digested and analyzed. Table 3-9 shows the analytical results for these digested solids based on grams of the analyte per gram of original sample. The major components which made up at least one percent of either sample are included. For other trace components and detection limits for undetected elements, see Appendix A.

Table 3-9. Major Cations in the Undissolved Solids for the SBS A3 Recycle and AN104SBS3565 Pretreated Waste

\begin{tabular}{|c|c|c|}
\hline \multirow[t]{2}{*}{ Analyte } & 0.097 M Na SBS A3 Recycle & $\begin{array}{c}4.74 \text { M Na AN104SBS3565 } \\
\text { Pretreated Waste }\end{array}$ \\
\hline & $\mu \mathrm{g} / \mathrm{g}(\mathrm{ppm})$ & $\mu \mathrm{g} / \mathrm{g}(\mathrm{ppm})$ \\
\hline $\mathrm{Al}$ & 13095 & 79600 \\
\hline $\mathrm{Ca}$ & 18670 & 8731 \\
\hline $\mathrm{Cr}$ & 1660 & 1000 \\
\hline $\mathrm{Fe}$ & 11050 & 4145 \\
\hline $\mathrm{K}$ & 2535 & $<10900$ \\
\hline $\mathrm{Li}$ & 80 & 5634 \\
\hline $\mathrm{Mg}$ & 1850 & 1990 \\
\hline $\mathrm{Na}$ & 9035 & 32400 \\
\hline $\mathrm{S}$ & 515 & 1670 \\
\hline $\mathrm{Si}$ & 26750 & 12443 \\
\hline $\mathrm{Sr}$ & 60 & 1960 \\
\hline $\mathrm{Ti}$ & 4800 & 1750 \\
\hline $\mathrm{U}$ & NM & 2150 \\
\hline $\mathrm{Zn}$ & 7930 & 744 \\
\hline $\mathrm{Zr}$ & 3320 & 805 \\
\hline
\end{tabular}


The solids filtered from the 4.74 M Na AN104SBS3565 pretreated waste concentrate were also analyzed by XRD. The two most prevalent compounds identified were $\mathrm{NaNO}_{3}$ and $\mathrm{LiAl}_{2}(\mathrm{OH})_{7} \cdot \mathrm{H}_{2} \mathrm{O}$. Also found, in decreasing order of abundance, were $\mathrm{NaNO}_{2}, \mathrm{SiO}_{2}$ (quartz) and $\mathrm{Na}_{3} \mathrm{H}\left(\mathrm{CO}_{3}\right)_{2} \cdot 2 \mathrm{H}_{2} \mathrm{O}$. When the filtrate was rinsed, the most prevalent compound was $\mathrm{Li}_{2} \mathrm{Al}_{2} \mathrm{O}_{4} \bullet \mathrm{H}_{2} \mathrm{O}$. The other compounds were, in decreasing order of abundance, $\mathrm{SiO}_{2}$ (quartz), $\mathrm{NaNO}_{2}$, and $\mathrm{NaNO}_{3}$. Lithium aluminum oxide/hydroxide compounds were not found in the SBS A3 recycle solids. However, the SBS A3 recycle had 48 ppm lithium prior to blending with the AN-104 pretreated waste, which has abundant aluminum. The XRD results indicate that lithium aluminum oxide/hydroxide compounds form during processing of the blended waste. The quantitative amount of solids in the $4.74 \mathrm{M} \mathrm{Na}$ AN104SBS3565 pretreated waste $(\sim 0.79 \mathrm{wt} \%)$ and the qualitative identification of the various crystals such as $\mathrm{NaNO}_{3}$, and $\mathrm{LiAl}_{2}(\mathrm{OH})_{7} \bullet \mathrm{H}_{2} \mathrm{O}$, indicate that no potentially troublesome or problematic solids were formed in this testing. Excessive solids formation or formation of solids that could coat evaporator surfaces, reboilers or pipelines could be potentially troublesome for the evaporation process. Solids-coating issues were not observed during the evaporation tests. Additionally, no sodium aluminosilicates (NAS) solids were detected in the product samples from these radioactive AN104SBS3565 pretreated wastes. NAS solids have been found in previous evaporation experiments with simulant LAW pretreated wastes and simulant SBS recycle (Josephs 2003). 


\subsection{RHEOLOGY AND PHYSICAL PROPERTIES}

\subsection{CONDUCT OF TESTING}

The radioactive LAW AN104SBS3565 pretreated wastes were characterized for:

- $\quad$ settling rates

- total density, supernatant density, settled solids density, and centrifuged solids density

- $\mathrm{wt}_{\mathrm{t}} \%$ centrifuged solids, $\mathrm{wt} \%$ settled solids, $\mathrm{wt} \%$ soluble solids in supernatant, $\mathrm{wt} \%$ total solids, $w \mathrm{t} \%$ oven dried solids, $\mathrm{wt} \%$ undissolved solids, and $\mathrm{wt} \%$ total oxides

- volume percent (vol\%) settled solids and vol\% centrifuged solids

- $\mathrm{pH}$

- rheology (flow curve measurements)

- $\quad$ particle size distribution (PSD)

The radioactive LAW AN104SBS3565 melter feeds were characterized for the same properties as that of the pretreated wastes listed above. The melter feeds were also characterized for settled solids shear strength.

The settling data was obtained using graduated centrifuge cones. The density data was obtained using the graduated centrifuge cone and graduated cylinder; the $\mathrm{wt} \%$ data using an oven/furnace and weighing balances; the $\mathrm{pH}$ using $\mathrm{pH}$ probes; viscosity of the pretreated waste from the flow curve; the melter feed flow curves fitted using various rheological models; reporting the largest shear stress of the settled solids using the vane as the settled solids shear strength; and the PSD using a laser scatter method.

The LAW AN104SBS3565 pretreated wastes were blended with RPP-WTP R\&T approved Glass Forming Chemicals (GFCs) (Schumacher 2003) to make the melter feeds. Laboratory scale mixing equipment was not scaled or operated based on the LAW MFPV/MFT design/operating conditions. The blended GFCs were added in a dry batched manner which does not reflect how the actual GFCs will be processed in the vitrification plant. Mixing conditions were determined by SRNL such that the condition of mixing (agitator speeds) provided a well mixed product based on visual observation (i.e., movement or flow patterns observed on the surface of the slurry). During mixing, a vortex was always maintained.

The elemental composition of the 5.1, 6.0 and 6.9 M Na LAW AN104SBS3565 pretreated wastes were calculated on the mass used and the ICP-ES and TIC/TOC analyses of the 7.29 M Na LAW AN104SBS3565 pretreated waste and the corresponding mass of DI water used or water evaporated. The elemental composition of the LAW AN104SBS3565 melter feeds were calculated based on the calculated elemental composition and mass used of the LAW AN104SBS3565 pretreated wastes and the corresponding batched mass of GFCs used and the vendor's elemental composition of the individual GFCs (Schumacher 2003). 
WSRC-TR-2004-00232, REVISION 0

SRNL-RPP-2004-00044, REVISION 0

\subsection{GLASS FORMER CHEMICALS AND AN-104 BATCH SHEET}

The GFCs utilized in this task are listed in Table 4-1 and are those approved by RPP-WTP R\&T (Schumacher 2003).

Table 4-1. Glass Former Chemicals Utilized

\begin{tabular}{|c|c|c|c|}
\hline $\begin{array}{c}\text { Primary Oxide } \\
\text { Added }\end{array}$ & Mineral & Grade & Vendor \\
\hline $\mathrm{Al}_{2} \mathrm{O}_{3}$ & Kyanite $-\mathrm{Al}_{2} \mathrm{O}_{2}-\mathrm{SiO}_{2}$ & Raw -325 Mesh & Kyanite Mining Corp. \\
\hline $\mathrm{B}_{2} \mathrm{O}_{3}$ & Boric Acid $-\mathrm{H}_{3} \mathrm{BO}_{3}$ & $\begin{array}{l}\text { Technical Grade- } \\
\text { Granular }\end{array}$ & U.S. Borax \\
\hline $\mathrm{Na}^{2} \mathrm{O}$ & $\mathrm{Na}_{2} \mathrm{CO}_{3}$ Anhydrous & Dense Soda Ash & Solvay Minerals \\
\hline $\mathrm{CaO}$ & Wollastonite $-\mathrm{CaSiO}_{3}$ & NYADM325 & NYCO \\
\hline $\mathrm{Fe}_{2} \mathrm{O}_{3}$ & $\mathrm{Fe}_{2} \mathrm{O}_{3}$ & 5001 & Prince Mfg. Co. \\
\hline $\mathrm{Li}_{2} \mathrm{O}$ & $\mathrm{Li}_{2} \mathrm{CO}_{3}$ & Technical Grade & Chemettal-Foote \\
\hline $\mathrm{MgO}$ & Olivine $-\mathrm{MgSiO}_{3}$ & $\# 180$ & Unimin Corp. \\
\hline $\mathrm{SiO}_{2}$ & $\mathrm{SiO}_{2}$ & SCS-75 & U.S. Silica \\
\hline $\mathrm{TiO}_{2}$ & Rutile $\mathrm{TiO}_{2} / \mathrm{Fe}_{2} \mathrm{O}_{3}$ & Air Floated Rutile 94 & Chemalloy Co. \\
\hline $\mathrm{ZnO}$ & $\mathrm{ZnO}$ & Kadox 920 & Zinc Corp America \\
\hline $\mathrm{ZrO}_{2}$ & $\mathrm{ZrSiO}_{4}$ & Zircon Flour & American Mineral Inc. \\
\hline None & Sugar & Fine Granulated sugar & $\begin{array}{l}\text { Amalgamated Sugar } \\
\text { Company }\end{array}$ \\
\hline
\end{tabular}

The chemical composition of the LAW AN104SBS3565 pretreated waste was provided to Vitreous State Laboratories (VSL). In return, VSL provided a GFC blend composition spreadsheet, LAWA137, as shown in Table 4-2. SRNL blended the VSL batch in a V-blender for 2 hours and the contents transferred to a wide mouth 2-L bottle. The actual mass of each GFC used in the batch is shown in Appendix C. The elemental composition of the blended GFCs is provided in section 4.8.1 and the vendor's elemental composition of each GFC is provided in Appendix C.

From the VSL batch sheet, SRNL determined the mass of homogenized blended GFCs required per mole of sodium in the pretreated waste. This value was 199.7 grams of blended GFCs per mole of sodium in the pretreated waste.

Three sub-samples from the batched GFCs were analyzed for elemental composition using ICP-ES. The average and standard deviation of the ICP-ES results are shown in Table C-3. The measured elemental composition compared well to that of the calculated elemental composition (Table C-3) of the batched GFCs. The calculated elemental composition was determined by using both the vendor data (Table C-1) and actual masses used in the batched GFCs (Table C-2). The errors associated with the measured results are due to the nonhomogeneity of the batched solids (this is evident in Figure 4-2, where solid clumps of individual GFCs are visually evident) and the error in the ICP-ES measurement. In this report, the elemental/oxide composition of the batched GFCs and melter feeds will be based on calculated elemental composition (e.g. vendor data + batched material). 
WSRC-TR-2004-00232, REVISION 0

SRNL-RPP-2004-00044, REVISION 0

Table 4-2. VSL GFC Batch Sheet LAWB98 for SRNL LAW AN104SBS3565 Pre-Treated Waste

\begin{tabular}{|c|c|c|c|c|c|c|c|c|c|c|c|c|c|c|c|c|c|c|c|c|}
\hline \multicolumn{21}{|c|}{ Batching recipe using Concentrate AN-104/SBS Blend for glass LAWA137 } \\
\hline \multirow{2}{*}{$\begin{array}{c}\text { Envelope } \\
\text { Constituents }\end{array}$} & \multicolumn{2}{|c|}{$\begin{array}{c}\text { AN 104/SBS blend } \\
\text { composition } \\
\text { provided by SRTC }\end{array}$} & \multirow{2}{*}{\begin{tabular}{|c|}
$\begin{array}{c}\text { Recommended } \\
\text { Na molarity } \\
\text { for Sample }\end{array}$ \\
6.00 \\
\end{tabular}} & \multirow{2}{*}{$\begin{array}{c}\text { Glass } \\
\text { Oxides } \\
\text { Loading } \\
\end{array}$} & \multirow{2}{*}{$\begin{array}{c}\text { Conversion } \\
\text { to oxide }\end{array}$} & \multirow{2}{*}{\begin{tabular}{|c|} 
AN-104/ \\
SBS blend \\
wt $\%$ \\
oxide \\
\end{tabular}} & \multirow{2}{*}{\begin{tabular}{|c|c|}
$\begin{array}{c}\text { AN-104/ } \\
\text { SBS wt } \% \\
\text { in glass }\end{array}$ \\
$20.146 \%$ \\
\end{tabular}} & \multirow{2}{*}{\begin{tabular}{|c|} 
LAWA137 \\
for SRTC \\
AN104/ \\
SBS blend \\
\end{tabular}} & \multicolumn{2}{|c|}{ Glass Formers } & \multirow[b]{2}{*}{ Source in Additives } & \multirow[b]{2}{*}{ Assay } & \multirow[b]{2}{*}{ Ratio } & \multirow{2}{*}{$\left|\begin{array}{c}\text { Target } \\
\text { Weight }(\mathrm{g})\end{array}\right|$} & \multicolumn{5}{|c|}{ Oxides Present } & \multirow[b]{2}{*}{ Vendor Inormation } \\
\hline & Moles/L & $\mathrm{mg} / \mathrm{L}$ & & & & & & & \begin{tabular}{|l|}
$100.00 \%$ \\
\end{tabular} & \begin{tabular}{|l|}
$79.85 \%$ \\
\end{tabular} & & & & & $\% \mathrm{Al}_{2} \mathrm{O}_{3}$ & $\% \mathrm{MgO}$ & $\% \mathrm{Fe}_{2} \mathrm{O}_{3}$ & $\% \mathrm{TiO}_{2}$ & $\% \mathrm{SiO}_{2}$ & \\
\hline $\mathrm{Al}$ & 0.0 .670 & $\begin{array}{ll}18,069 \\
\end{array}$ & 0.852 & $\mathrm{Al}_{2} \mathrm{O}_{3}$ & $\begin{array}{l}34.14 \\
\end{array}$ & 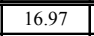 & 3.419 & 6.05 & 3.29 & 2.63 & Kyanite $\left(\mathrm{Al}_{2} \mathrm{SiO}_{5}\right) 325 \mathrm{Mesh}$ & 0.9990 & \begin{tabular}{|l|l|}
0.540 \\
\end{tabular} & \begin{tabular}{l|l|l}
58.201 \\
\end{tabular} & $0.00 \%$ & $0.00 \%$ & (0.51\% & $0.00 \%$ & $42.40 \%$ & Kyanite Mining \\
\hline $\mathrm{B}$ & 0.056 & 606 & 0.071 & $\mathrm{~B}_{2} \mathrm{O}_{3}$ & 1.95 & 0.97 & 0.195 & 9.91 & 12.17 & 9.72 & $\mathrm{H}_{3} \mathrm{BO}_{3}$ & 0.986 & 0.563 & 222.341 & $0.00 \%$ & \begin{tabular}{|l|l|}
$0.00 \%$ \\
\end{tabular} & $0.00 \%$ & $0.00 \%$ & $0.00 \%$ & US Borax \\
\hline $\mathrm{Ca}$ & 0.002 & 94 & 0.003 & $\mathrm{CaO}$ & 0.00 & 0.00 & 0.000 & 5.03 & 6.29 & 5.03 & \multirow[t]{2}{*}{ Wollanstonite NYAD 325 Mesh } & 0.993 & \begin{tabular}{|l|l|}
0.475 \\
\end{tabular} & \multirow[t]{2}{*}{135.299} & $1.07 \%$ & \begin{tabular}{|l|l|}
$0.82 \%$ \\
\end{tabular} & \multirow{2}{*}{$0.11 \%$} & \begin{tabular}{|l|l|}
$0.00 \%$ \\
\end{tabular} & $52.52 \%$ & NYCO Minerals \\
\hline $\mathrm{Cr}$ & 0.003 & 175 & 0.004 & $\mathrm{Cr}_{2} \mathrm{O}_{3}$ & 0.26 & 0.13 & 0.026 & 0.03 & & & & & & & & & & & & \\
\hline $\mathrm{Fe}$ & 0.001 & 42 & 0.001 & $\mathrm{Fe}_{2} \mathrm{O}_{3}$ & 0.00 & 0.00 & 0.000 & 5.36 & 6.72 & 5.36 & \multirow{2}{*}{\multicolumn{3}{|c|}{$\mathrm{Fe}_{2} \mathrm{O}_{3}$}} & 64.938 & $0.00 \%$ & $0.00 \%$ & $0.00 \%$ & $0.00 \%$ & $0.00 \%$ & \multirow{2}{*}{ Prince Manufacturing } \\
\hline $\mathrm{K}$ & 0.131 & 5,129 & 0.167 & $\mathrm{~K}_{2} \mathrm{O}$ & 6.18 & 3.07 & 0.619 & 0.62 & & & & & & & & & & & & \\
\hline $\mathrm{Li}$ & 0.009 & 59 & 0.011 & $\mathrm{Li}_{2} \mathrm{O}$ & 0.13 & 0.06 & 0.013 & 2.48 & 3.09 & 2.46 & Li22C3 (Chemetall Foote Co. Tech. gr.) & 0.990 & 0.404 & 78.248 & $0.00 \%$ & $0.00 \%$ & $0.00 \%$ & $0.00 \%$ & $0.00 \%$ & \multirow{2}{*}{\begin{tabular}{|c|} 
Chemetall Foote Co. Tech. g \\
UNIMIN Corp.
\end{tabular}} \\
\hline $\mathrm{Mg}$ & 0.001 & 20 & 0.001 & $\mathrm{MgO}$ & 0.00 & 0.00 & 0.000 & 1.48 & 1.85 & 1.48 & \multirow[t]{2}{*}{ Olivine $\left(\mathrm{Mg}_{2} \mathrm{SiO}_{4}\right) 325 \mathrm{Mesh}(\# 180)$} & 0.990 & 0.480 & 37.192 & $0.00 \%$ & $0.00 \%$ & $7.68 \%$ & $0.00 \%$ & $42.52 \%$ & \\
\hline Mo & 0.001 & 51 & 0.001 & $\mathrm{MoO}_{3}$ & 0.08 & 0.04 & 0.008 & 0.01 & - & 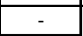 & & & & & & & & & & \\
\hline $\mathrm{Na}$ & 4.718 & \begin{tabular}{|l|}
108,467 \\
\end{tabular} & 6.000 & $\mathrm{Na}_{2} \mathrm{O}$ & 146.21 & 72.67 & 14.641 & 14.64 & - & & & & & & & & & & & \\
\hline $\mathrm{Si}$ & 0.011 & 316 & 0.014 & $\mathrm{SiO}_{2}$ & 0.68 & 0.34 & 0.068 & 46.07 & 57.60 & 46.00 & SiO2 (Sil-co-Sil 75) & 0.997 & 1.000 & 454.894 & $0.00 \%$ & $0.00 \%$ & $0.00 \%$ & $0.00 \%$ & $0.00 \%$ & US SILICA \\
\hline $\mathrm{Ti}$ & 0.000 & 18 & 0.000 & $\mathrm{TiO}_{2}$ & 0.00 & 0.00 & 0.000 & 1.13 & 1.42 & 1.13 & Rutile Sand Premium Airfloated & 0.954 & 1.000 & 15.024 & $4.50 \%$ & $0.00 \%$ & $0.00 \%$ & $0.00 \%$ & $0.00 \%$ & Chemalloy \\
\hline $\mathrm{Zn}$ & 0.001 & 64 & 0.001 & $\mathrm{ZnO}$ & 0.00 & 0.00 & 0.000 & 3.04 & 3.81 & 3.04 & $\mathrm{ZnO}$ & 0.997 & 1.000 & 38.724 & $0.00 \%$ & $0.00 \%$ & $0.00 \%$ & \begin{tabular}{|l|l|}
$0.00 \%$ \\
\end{tabular} & $0.00 \%$ & Zinc Corp. of America \\
\hline $\mathrm{Zr}$ & 0.000 & 9 & 0.000 & $\mathrm{ZrO}_{2}$ & 0.00 & 0.00 & 0.000 & 3.00 & 3.76 & 3.00 & Zircon $\mathrm{ZrSiO}_{4}$ (Flour) Mesh 325 & 0.990 & \begin{tabular}{|l|l|}
0.673 \\
\end{tabular} & 57.224 & $0.31 \%$ & $0.00 \%$ & $0.00 \%$ & $0.12 \%$ & $33.35 \%$ & American Mineral \\
\hline $\mathrm{Cl}$ & 0.213 & 7,545 & 0.271 & $\mathrm{Cl}$ & 7.55 & 3.75 & 0.756 & 0.76 & & & Sugar & & & 36.129 & & & & & & \\
\hline $\mathrm{F}$ & 0.008 & 145 & 0.010 & $\mathrm{~F}$ & 0.15 & 0.07 & 0.015 & 0.02 & & & Number of moles of sodium used & & & 6.000 & & & & & & \\
\hline $\mathrm{PO}_{4}$ & 0.015 & 1,425 & 0.019 & $\mathrm{P}_{2} \mathrm{O}_{5}$ & 1.06 & 0.53 & 0.107 & 0.11 & & & Expected Glass yield (g) & & & 1269.995 & & & & & & \\
\hline $\mathrm{SO}_{4}$ & 0.035 & 3,375 & 0.045 & $\mathrm{SO}_{3}$ & 2.81 & 1.40 & 0.282 & 0.28 & & & Sum of additives including sugar $(\mathrm{g})$ & & & 1198.214 & & & & & & \\
\hline $\mathrm{NO}_{2}$ & 0.812 & 37,350 & 1.033 & $\mathrm{NO}_{2}$ & 37.35 & & & & & & Estimated weight of complete batch $(\mathrm{g})$ & & & 2488.214 & & & & & & \\
\hline $\mathrm{NO}_{3}$ & 0.869 & 53,900 & 1.106 & $\mathrm{NO}_{3}$ & 53.90 & & & & & & Volume of AN-104 Sample used (ml) & & & 1000 & & & & & & \\
\hline $\mathrm{CO}_{3}$ & 0.064 & 3,815 & 0.081 & $\mathrm{CO}_{3}$ & 3.82 & & & & & & Estimated weight of AN-104 sample used & & & 1290 & & & & & & \\
\hline \begin{tabular}{|l|} 
Org.Carbon \\
\end{tabular} & 0.264 & 3,170 & 0.336 & Cas: & 3.17 & & & & & & Feed density (g/ml) (estimated) & & & 1.29 & & & & & & \\
\hline & & & & SUM & 299.42 & 100.00 & 20.146 & 100.00 & 100.0 & 79.85 & Recommended Sodium Molarity & & & 6.00 & & & & & & \\
\hline
\end{tabular}


WSRC-TR-2004-00232, REVISION 0

SRNL-RPP-2004-00044, REVISION 0

\subsection{LAW AN104SBS3565 SAMPLE PREPARATION}

\subsubsection{LAW AN104SBS3565 Pretreated Waste}

The 7.29 M Na AN104SBS3565 pretreated waste concentrated by evaporation described in Section 3.2.3 and in Appendix B was used for all subsequent rheology and physical properties testing. The composition of the $7.29 \mathrm{M}$ Na pretreated waste is shown in Appendix B, Table B-1. Three different targeted sodium concentrations of 5.1, 6.0, and 6.9 M Na were batched from this $7.29 \mathrm{M}$ Na pretreated waste using graduated cylinders. The volumes of pretreated waste and DI water are provided in Appendix B, Table B-2. These pretreated wastes were analyzed for weight percent solids, settling, oxides, and flow curves per the RPP-WTP characterization procedure (Smith 2002). Sub-samples of each of these pretreated wastes were also characterized for sodium concentration using both ICP-ES and AA.

\subsubsection{LAW AN104SBS3565 Melter Feed}

Table B-2 reports the measured sodium molarity of the 3 different concentrations of pretreated waste using both AA and ICP-ES. The average sodium molarities were approximately $0.5 \mathrm{M} \mathrm{Na}$ lower than originally targeted. This indicated that the starting $\mathrm{Na}$ molarity of the $7.29 \mathrm{M}$ Na pretreated waste is lower than what was previously measured and reported in this report. SRNL performed calculations to determine the molarity of the 7.29 $\mathrm{M}$ Na pretreated waste using the measured physical properties and molarities of the diluted pretreated wastes. Details of this calculation are provided in Appendix B. The results indicate that the sodium molarity of the $7.29 \mathrm{M}$ Na pretreated feed was approximately 6.75 $\mathrm{M} \mathrm{Na}$. SRNL then proceeded in correcting the sodium molarity of the three pretreated wastes previously batched by either adding additional $7.29 \mathrm{M} \mathrm{Na}$ pretreated waste (using a $\mathrm{Na}$ molarity of $6.75 \mathrm{M} \mathrm{Na}$ ) and/or evaporation to their original targeted (5.1, 6.0 and 6.9) sodium molarities in preparation for melter feed testing. The final density, Na molarity, moles of sodium, volume and mass of the 5.1, 6.0, and 6.9 $\mathrm{M}$ Na pretreated wastes are shown in Table B-5. The volume of the 7.29 M Na pretreated waste used to make up the melter feed for testing is provided in Table B-6.

No physical or chemical analyses of these final concentrated pretreated wastes were measured prior to using them for melter feed testing. The Na concentration, density, and compositional data for all the batched pretreated wastes were all calculated. It is assumed that the other chemical species analyzed for the $7.29 \mathrm{M} \mathrm{Na}$ pretreated waste are not in error.

The quantity of blended GFCs required for each melter feed was determined by the number of moles of sodium in the pretreated waste. Given the moles of sodium in the pretreated waste, the mass (grams) of blended GFCs was determined (multiplied moles of Na by 199.7). Presented in Table 4-3 are the moles of sodium in the pretreated waste, the target glass former addition based on the moles of $\mathrm{Na}$, and the actual amount of GFCs added for making the melter feed. 
WSRC-TR-2004-00232, REVISION 0 SRNL-RPP-2004-00044, REVISION 0

Table 4-3. Mass of Blended GFCs Used For the Various Pretreated Wastes

\begin{tabular}{|l|c|c|c|}
\cline { 2 - 4 } \multicolumn{1}{c|}{} & \multicolumn{3}{c|}{ Sodium Molarity of Starting Pretreated Waste } \\
\cline { 2 - 4 } \multicolumn{1}{c|}{} & $\mathbf{5 . 1} \mathbf{~ M}$ & $\mathbf{6 . 0} \mathbf{~ M}$ & $\mathbf{6 . 9} \mathbf{~ M}$ \\
\hline Moles of Na in pretreated waste & 0.602 & 1.599 & 0.815 \\
\hline Mass of GFCs - Target (g) & 120.12 & 319.38 & 162.80 \\
\hline Mass of GFCs - actual (g) & 120.21 & 323.858 & 163.055 \\
\hline
\end{tabular}

The blended GFCs from the V-blender were then transferred to individual large wide mouth plastic bottle for each of the pretreated feeds as shown in Table 4-3. During the transfer of the blended GFCs to the large wide-mouth plastic bottle, white clumps (Figure 4-2) in the blended GFCs were visually observed. White clumps were not sampled from the remaining batched GFCs that was not used for making melter feed, hence the source of these white clumps are unknown. Of the GFCs used in this batch, it is suspected that these white clumps could be from the GFC that provides the boric acid, lithium carbonate or silica.

Laboratory slurry mixing equipment was selected based on the calculated volume of melter feed that would result from the blending of the pretreated waste with the GFCs. The mixing equipment used for making the 5.1,6.0, and 6.9 M Na AN104SBS3565 melter feeds is described in Table 4-4. The plastic caps used for the mixing vessels were predrilled with holes slightly off-center and slightly larger than the diameter of the agitator shaft. The agitator shaft holes were placed slightly off-center to allow for better mixing, since no baffles were present in any of the mixing vessels.

First, the pretreated waste was added to the mixing vessel. The agitator impeller was then installed off-center and as close to the bottom of the mixing vessel as possible. The mixer was then started and the initial agitator speed was determined by visually observing for the presence of a vortex, such that the GFC solids could be easily entrained and dispersed by agitation. The GFCs were added manually with a spatula at a rate that could easily be blended into the mixture (based on visual observation). If it took approximately 20 to 30 seconds for the mass of GFCs added to become entrained and dispersed, GFC addition was stopped and the mass of GFCs remaining to be added and the time the GFCs were added at that specific agitator speed was recorded. The agitator speed was increased until an adequate vortex was again obtained and this cycle was repeated until all the GFCs were added.

Figure 4-1 shows the $5.1^{4} \mathrm{M}$ Na melter feed after all of the GFCs were added and no bubbles were noted when the agitation was stopped. Figure 4-2 shows the $6.9 \mathrm{M} \mathrm{Na}$ melter feed during GFC addition and after GFC addition was completed. The bubbles present in Figure 4-2 were most likely due to air that was entrained during GFC addition, and not by the vortex itself. After 24 hour of mixing, all the bubbles were gone. The effect of bubbles generated due to air entrainment during the addition of GFCs could be a factor within the WTP. The bubbles were only noticed in the $6.9 \mathrm{M} \mathrm{Na}$ melter feed. After all the GFCs were added, the slurry, agitator shaft/blade, and vessel cap were weighed. This was considered the

\footnotetext{
${ }^{4}$ The actual sodium molarity of the melter feed is different than that of the pretreated feed. The same sodium molarity of the corresponding pretreated waste is used to describe the melter feed, so that the reader can easily compare the effects of the GFCs to the pretreated waste.
} 
WSRC-TR-2004-00232, REVISION 0

SRNL-RPP-2004-00044, REVISION 0

baseline weight of the blended slurry, container, and agitator. The addition rate of the GFCs and agitator speeds are shown in Table 4-5. In all cases, the agitator speed increased during $\mathrm{GFC}$ addition and was greatest for the $6.9 \mathrm{M} \mathrm{Na}$ melter feed.

Table 4-4. Description of Mixing Tanks and Agitators Used To Make Melter Feed

\begin{tabular}{|c|c|c|c|}
\hline \multirow[b]{2}{*}{ Description } & \multicolumn{3}{|c|}{ Sodium Molarity of Starting Pretreated Waste } \\
\hline & 5.1 M Na Melter Feed & 6.0M Na Melter Feed & 6.9M Na Melter Feed \\
\hline Order of GFC Addition & GFCs were pre-blended & GFCs were pre-blended & GFCs were pre-blended \\
\hline Mixing Time & 24 hours & 7 days & 24 hours total \\
\hline Impeller Diameter D (mm) & 50.69 & 50.69 & 50.69 \\
\hline Impeller Height H (mm) & 10.30 & 10.30 & 10.30 \\
\hline Impeller Width W (mm) & 2.21 & 2.21 & 2.21 \\
\hline Blade Length L (mm) & 12.40 & 12.40 & 12.40 \\
\hline Type of Impeller & Rushton & Rushton & Rushton \\
\hline Tank Type & $\begin{array}{l}\text { Right Cylinder Plastic } \\
\text { Cup }\end{array}$ & $\begin{array}{l}\text { Right Cylinder Plastic } \\
\text { Cup }\end{array}$ & $\begin{array}{l}\text { Right Cylinder Plastic } \\
\text { Cup }\end{array}$ \\
\hline Tank Inside Diameter (mm) & 82.6 & 82.6 & 82.6 \\
\hline Tank Height (mm) & 63.5 & 127.0 & 63.5 \\
\hline Number of Baffles & None & None & None \\
\hline Size of Baffles & None & None & None \\
\hline Depth of impeller & Just off bottom & Just off bottom & Just off bottom \\
\hline Location of impeller (mm) & Slightly off-centered & Slightly off-centered & Slightly off-centered \\
\hline $\begin{array}{c}\text { Comments } \\
\text { (Rushton Blade) }\end{array}$ & $\left\{\begin{array}{l}4 \\
4 \\
1 \\
1\end{array}\right.$ & - & $\mathrm{W}^{\mathrm{W}}$ \\
\hline
\end{tabular}


WSRC-TR-2004-00232, REVISION 0

SRNL-RPP-2004-00044, REVISION 0

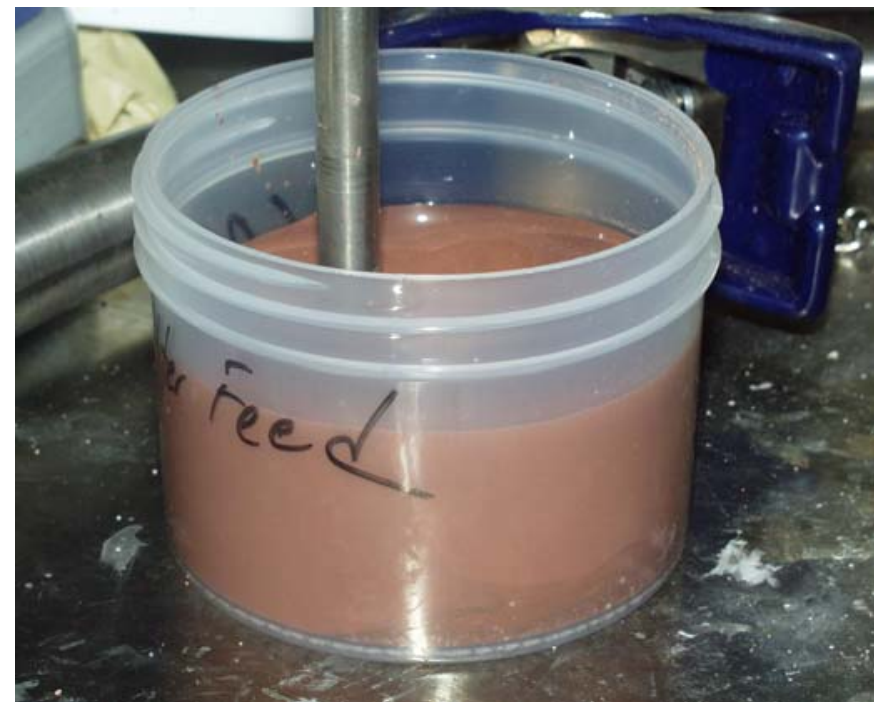

Figure 4-1. GFCs Added to Make 5.1 M Na AN104SBS3565 Melter Feed
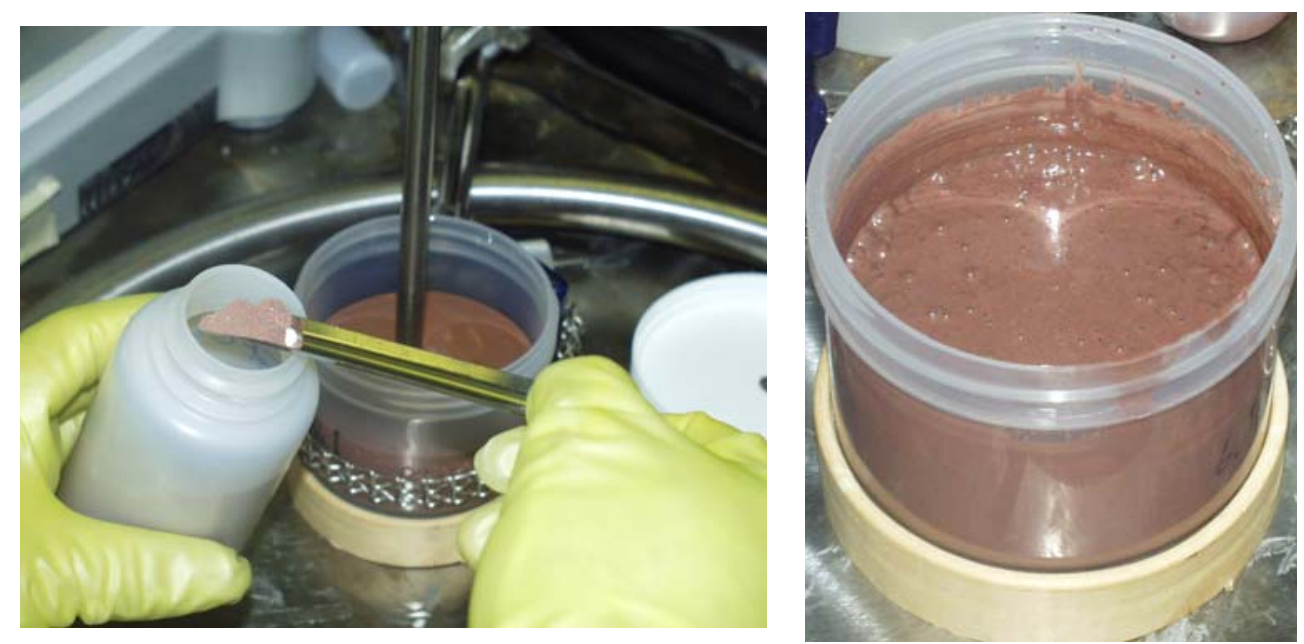

Figure 4-2. GFCs Being Added and After Complete GFC Addition for 6.9 M Na AN104SBS3565 Melter Feed 
WSRC-TR-2004-00232, REVISION 0

SRNL-RPP-2004-00044, REVISION 0

Table 4-5. Agitator Speeds during GFCs Addition and Extended Mixing

\begin{tabular}{|c|c|c|c|c|c|c|c|c|}
\hline \multicolumn{9}{|c|}{ Sodium Molarity of Starting Pretreated Waste } \\
\hline \multicolumn{3}{|c|}{ 5.1M Na Melter Feed } & \multicolumn{3}{|c|}{ 6.0M Na Melter Feed } & \multicolumn{3}{|c|}{ 6.9M Na Melter Feed } \\
\hline $\begin{array}{c}\text { Time } \\
\text { Minutes }\end{array}$ & $\begin{array}{c}\text { Agitator } \\
\text { Speed } \\
\text { RPM }\end{array}$ & $\begin{array}{c}\text { Cumulative } \\
\text { Mass of } \\
\text { GFCs } \\
\text { added (g) }\end{array}$ & $\begin{array}{c}\text { Time } \\
\text { Minutes }\end{array}$ & $\begin{array}{c}\text { Agitator } \\
\text { Speed } \\
\text { RPM }\end{array}$ & $\begin{array}{c}\text { Cumulative } \\
\text { Mass of } \\
\text { GFCs } \\
\text { added (g) }\end{array}$ & $\begin{array}{c}\text { Time } \\
\text { Minutes }\end{array}$ & $\begin{array}{c}\text { Agitator } \\
\text { Speed } \\
\text { RPM }\end{array}$ & $\begin{array}{c}\text { Cumulative } \\
\text { Mass of } \\
\text { GFCs } \\
\text { added (g) }\end{array}$ \\
\hline Initial & 200 & 0 & Initial & 300 & 0 & Initial & 204 & 0 \\
\hline 3 & 250 & 45.9 & 3 & 350 & 130.2 & 5 & 230 & 38.4 \\
\hline 7 & 300 & 92.8 & 5 & 400 & 182.2 & 7.5 & 270 & 60.3 \\
\hline 8.5 & 350 & 120.21 & 7 & 400 & 234.7 & 13.5 & 320 & 130.1 \\
\hline \multirow{4}{*}{$\begin{array}{c}\text { First } \\
\text { day }\end{array}$} & \multirow{4}{*}{350} & \multirow{4}{*}{$\mathrm{N} / \mathrm{A}$} & 9 & 475 & 306.2 & 15.5 & 680 & 163.06 \\
\hline & & & 10 & 475 & 323.86 & \multirow{3}{*}{ First day } & \multirow{3}{*}{680} & \multirow{3}{*}{ N/A } \\
\hline & & & First day & 475 & N/A & & & \\
\hline & & & $\begin{array}{c}\text { Next } 6 \\
\text { days }\end{array}$ & 450 & N/A & & & \\
\hline
\end{tabular}

The mixing system was reconfigured with the cap in place and the impeller located just offbottom. After all the GFCs were added, the final agitator speed was adjusted to provide an adequate vortex that resulted in a system where melter feed motion was observed everywhere and was maintained until the sample was analyzed. After the baseline weight of the $6.9 \mathrm{M}$ Na melter feed was obtained (after all the GFCs had been added), it was observed that during this period of no mixing, the $6.9 \mathrm{M} \mathrm{Na}$ had become more viscous, resulting in the agitator speed having to be increased such that an adequate mixing was observed throughout the mixing vessel.

For the $6.0 \mathrm{M} \mathrm{Na}$ melter feed, a sample was pulled after 1 day of mixing and a new agitator speed was set based on the new volume of material in the mixing vessel. One hour prior to pulling samples for analyses, the slurry, agitator shaft/blade, and tank cap were weighed. This mass was compared to the baseline weight. If there was a difference in the mass from the baseline weight, the difference was compensated with the addition of DI water. The difference in the mass was attributed to the evaporation of water from the mixing system. The largest quantity of water loss was 3.5 grams for the $6.9 \mathrm{M} \mathrm{Na}$ melter feed. After the 1 day sample had been pulled for the $6.0 \mathrm{M} \mathrm{Na}$ melter feed, the mass of water lost after 6 days of mixing was 1.5 grams.

\subsection{PHYSICAL PROPERTIES TESTING}

The physical properties of the LAW AN104SBS3565 pretreated wastes and melter feeds were measured in accordance with the project Guidelines (Smith 2002). The following properties were either measured or calculated:

- density of slurry, density of supernatant, density of settled solids, and density of centrifuged solids $(\mathrm{g} / \mathrm{mL})$

- $\quad$ wt $\%$ and vol $\%$ of settled solids and vol $\%$ centrifuged solids 
- $\mathrm{wt} \%$ total solids, $\mathrm{wt} \%$ dried solids, $\mathrm{wt} \%$ oven dried solids, $\mathrm{wt} \%$ undissolved solids (UDS), and $\mathrm{wt} \%$ total oxides

- settling rate (interfacial volume level versus time)

All the physical properties measurements were performed at room temperature $\left(18\right.$ to $\left.23^{\circ} \mathrm{C}\right)$ unless otherwise specified. Rheological properties are discussed separately in section 4.6.

\subsubsection{Methodology for Measuring Physical Properties}

\subsubsection{General Method for Sample Prep and Analysis}

This section describes how a pretreated waste and/or melter feed sample was handled and the variables calculated, in accordance with the project Guidelines procedure (Smith 2002). Triplicate samples were run for each waste stream at room temperature, unless otherwise noted. The pretreated waste samples required for the physical properties measurement were obtained by physically shaking the contents in the bottle prior to sampling. After mixing, a sample was extracted from the bottle using a pipette. For melter feed samples, samples were pulled using a $5 \mathrm{~mL}$ slurry pipette from the mixing vessel, while maintaining a slight vortex and good mixing.

Between 7 to $10 \mathrm{~mL}$ of a sample was placed into a $10 \mathrm{~mL}$ volumetric graduated centrifuge cone. The mass $\left(\mathrm{M}_{\mathrm{B}}\right)$ and volume of the sample were recorded. The sample was then allowed to settle for at least 3 days. A detailed description of the settling test is provided in section 4.4.2. After the settling tests were completed, the total volume $\left(\mathrm{V}_{\mathrm{SB}}\right)$ of the sample and the volume of settled solids $\left(\mathrm{V}_{\mathrm{SS}}\right)$ were recorded. The error associated with this measurement is estimating the total volume, which may be under or over estimated, based on how the meniscus was read. Additionally, the materials hanging onto the sides of the tube would slightly decrease the level of settled slurry and the total volume.

The settled solids were then centrifuged at approximately one thousand times the force of gravity for 60 minutes. The total volume after centrifuging $\left(\mathrm{V}_{\mathrm{B}}\right)$ and the solids volume after centrifuging $\left(\mathrm{V}_{\mathrm{CS}}\right)$ were recorded. The bulk density (Equation 4-1), vol\% settled solids (Equation 4-2) and vol\% centrifuged solids (Equation 4-3) were then calculated.

Equation 4-1 $\quad \rho_{B}=\frac{M_{B}}{V_{B}}$

Equation 4-2 $\quad P_{V S S}=\frac{V_{S S}}{V_{B}} \cdot 100 \%$

Equation 4-3

$$
P_{V C S}=\frac{V_{C S}}{V_{B}} \cdot 100 \%
$$


The transparent supernatant was then transferred from the centrifuged cone to a graduated cylinder. The mass $\left(\mathrm{M}_{\mathrm{S}}=\mathrm{M}_{\mathrm{VL}}\right.$ in this case $)$ and volume $\left(\mathrm{V}_{\mathrm{S}}\right)$ of the supernatant and the mass $\left(\mathrm{M}_{\mathrm{CS}}\right)$ of centrifuged solids were recorded. The density of the supernatant (Equation 4-4), the density of centrifuged solids (Equation 4-5), the wt\% centrifuged solids (Equation 4-6), the mass of settled solids (Equation 4-7), density of settled solids (Equation 4-8) and wt $\%$ of settled solids (Equation 4-9) were then calculated. Variables that could potentially impact these results are:

- Air entrainment. Air could potentially be released during centrifuging. Differences in the final volume between the settling and centrifuged total volume would indicate that such a condition exists. It is also possible that the bubbles would not be released by centrifuging. Correction to the data set requires making assumptions that could bias the results.

- The volume of supernatant transferred from the cone to the graduated cylinder is not $100 \%$ (i.e., not all the free standing supernatant was transferred). This would bias the wt $\%$ of undissolved solids high. The opposite would be true if insoluble solids were transferred for supernatant analysis.

- Volume of supernatant, as read on the graduated cylinder, could bias the density result high or low. This would impact the settled solids results.

Equation 4-4

$$
\rho_{S}=\frac{M_{S}}{V_{S}}
$$

Equation 4-5 $\rho_{C S}=\frac{M_{C S}}{V_{C S}}$

Equation 4-6

$$
P_{V C S}=\frac{M_{C S}}{M_{B}} \cdot 100 \%
$$

Equation 4-7

$$
M_{S S}=M_{B}-\rho_{S} \cdot\left(V_{S B}-V_{S S}\right)
$$

Equation 4-8

$$
\rho_{S S}=\frac{M_{S S}}{V_{S S}}
$$

Equation 4-9 $\quad P_{S S}=\frac{M_{S S}}{M_{B}} \cdot 100 \%$ 
WSRC-TR-2004-00232, REVISION 0

SRNL-RPP-2004-00044, REVISION 0

The graduated cylinder containing the supernatant and the centrifuged cone containing the centrifuged solids were then placed overnight into a drying oven at $90^{\circ} \mathrm{C}$ The oven temperature was then increased to $105^{\circ} \mathrm{C}$ and the sample was maintained in the oven until the dried weights stabilized (approximately 2 days). The mass of the dried supernatant solids $\left(\mathrm{M}_{\mathrm{DCL}}\right)$ and mass of the dried centrifuged solids $\left(\mathrm{M}_{\mathrm{DCS}}\right)$ were recorded. Assuming that the mass lost is only water, the $\mathrm{wt} \%$ soluble solids in the supernatant (Equation $4-10$ ), $\mathrm{wt} \%$ total dried solids (Equation 4-11), wt. \% oven dried solids (Equation 4-12) and wt\% UDS (Equation 4-13) were then calculated. Variables that could potentially impact these results are:

- Volatiles (organics) lost during the oven drying process. Organics could be lost in both the supernatant and centrifuged solids and could result in a lower solids measurement.

- Formation of a hard solid surface over the top of the samples during the evaporation process, which does not allow for the releasing of water (observed with high salt solutions and melter feeds). This condition would yield higher solids measurements. One way to prevent this would be to increase the surface area of the sample.

Equation 4-10

$$
P_{S S S}=\frac{M_{D C L}}{M_{V L}} \cdot 100 \%
$$

Equation 4-11

$$
P_{M T S}=\left[\frac{P_{S S S}}{100 \%} \cdot \frac{M_{S}}{M_{B}}+\frac{M_{D C S}}{M_{B}}\right] \cdot 100 \%
$$

Equation 4-12

$$
P_{O D S}=\frac{M_{D C S}}{M_{C S}} \cdot 100 \%
$$

Equation 4-13

$$
P_{M U S}=\left[1-\frac{1-\frac{M_{D C L}}{M_{C S}}}{1-\frac{M_{D C L}}{M_{V L}}}\right] \cdot \frac{M_{C S}}{M_{B}} \cdot 100 \%
$$

Homogenized samples were also transferred to a $50-\mathrm{mL}$ pre-fired high-purity alumina crucible. The mass of the sample transferred was recorded $\left(\mathrm{M}_{\mathrm{WCS}}\right)$ and the crucible placed overnight into an oven at $90^{\circ} \mathrm{C}$. The oven temperature was increased to $105^{\circ} \mathrm{C}$ and the sample was maintained in the oven until the dried weight stabilized (about 1 day). The ovendried mass $\left(\mathrm{M}_{\mathrm{OSC}}\right)$ was recorded and the wt\% dried sample (Equation 4-14) calculated. The sample was then placed into a resistance-heated furnace at room temperature, the temperature was raised $\left(200^{\circ} \mathrm{C} / \mathrm{hr}\right)$ to $1050^{\circ} \mathrm{C}$ and maintained at that temperature for 1 hour. The sample was then allowed to cool in the furnace. The weight of the oven fired sample $\left(\mathrm{M}_{\mathrm{FSC}}\right)$ was recorded and the wt\% total oxides (Equation 4-15) calculated. The wt\% UDS (Equation 
4-16) was then calculated using the method employed by SRNL using the $\mathrm{wt} \%$ Total Solids (TS) determined by the crucible method and the $\mathrm{wt} \%$ soluble solids determined in the supernatant (as calculated above). The same issues as described in section 4.4.1.2 could also impact the $\mathrm{wt} \%$ dried solids in the sample. Impacts to the $\mathrm{wt} \%$ total oxides could also occur due to volatilization of specific oxides, resulting in a lower $\mathrm{wt} \%$.

Equation 4-14

$$
P_{M D S}=\frac{M_{O S C}}{M_{W C S}} \cdot 100 \%
$$

Equation 4-15

$$
P_{M O X}=\frac{M_{F S C}}{M_{W C S}} \cdot 100 \%
$$

Equation 4-16

$$
P_{M U S, S R N L}=\left[\frac{P_{M D S}-P_{S S S}}{100-P_{S S S}}\right] \cdot 100 \%
$$

The standard deviations of the measured and calculated values are reported. Calculations to estimate uncertainty in the mass and volume measurements were not included. 
WSRC-TR-2004-00232, REVISION 0

SRNL-RPP-2004-00044, REVISION 0

\subsubsection{LAW AN104SBS3565 Pretreated Waste Physical Properties}

Since the LAW AN104SBS3565 pretreated wastes contained visible insoluble solids, the complete RPP method for solids analysis as described in section 4.4.1.1 was performed. The results are listed in Table 4-6. The actual sodium molarities of the pretreated wastes are shown in the table.

Table 4-6. Solids Analysis of LAW AN104SBS3565 Pretreated Wastes

\begin{tabular}{|c|c|c|c|c|c|c|c|c|}
\hline & \multirow[b]{3}{*}{ Description } & \multirow[b]{3}{*}{ Units } & \multicolumn{6}{|c|}{ Targeted Na Molarities Pretreated Wastes } \\
\hline & & & \multicolumn{2}{|c|}{$\begin{array}{l}5.1 \mathrm{M}(4.73 \mathrm{M} \\
\mathrm{Na} \text { actual) }\end{array}$} & \multicolumn{2}{|c|}{$\begin{array}{l}6.0 \mathrm{M}(5.61 \mathrm{M} \\
\text { Na actual) }\end{array}$} & \multicolumn{2}{|c|}{$\begin{array}{c}6.9 \mathrm{M}(6.23 \mathrm{M} \\
\mathrm{Na} \text { actual) }\end{array}$} \\
\hline & & & Avg. & SD* & Avg. & SD* & Avg. & SD* \\
\hline \multirow{12}{*}{ 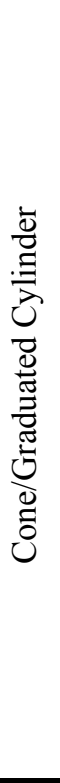 } & Bulk Density $-\rho_{B}$ & $\mathrm{~g} / \mathrm{mL}$ & 1.23 & 0.01 & 1.26 & 0.02 & 1.30 & 0.00 \\
\hline & Vol \% Settled Solids - $P_{\text {VsS }}$ & $\%$ & 10.9 & 0.25 & 14.16 & 0.57 & 19.69 & 0.79 \\
\hline & Density of Centrifuged Solids - $\rho_{\mathrm{CS}}$ & $\mathrm{g} / \mathrm{mL}$ & 1.36 & 0.12 & 1.33 & 0.03 & 1.34 & 0.06 \\
\hline & Vol \% Centrifuged Solids - $P_{\mathrm{VCS}}$ & $\%$ & 6.57 & 0.18 & 9.44 & 0.33 & 12.15 & 0.63 \\
\hline & Wt. \% Centrifuged Solids - $\mathrm{P}_{\mathrm{MCS}}$ & $\%$ & 7.28 & 0.52 & 9.97 & 0.17 & 12.49 & 0.42 \\
\hline & Supernatant Liquid Density - $\rho_{\mathrm{S}}$ & $\mathrm{g} / \mathrm{mL}$ & 1.23 & 0.01 & 1.26 & 0.01 & 1.31 & 0.01 \\
\hline & Density of Settled Solids - $\rho_{\mathrm{SS}}$ & $\mathrm{g} / \mathrm{mL}$ & 1.23 & 0.09 & 1.24 & 0.08 & 1.28 & 0.04 \\
\hline & Wt. \% Settled Solids - $\mathrm{P}_{\mathrm{MSS}}$ & $\%$ & 10.96 & 0.56 & 13.96 & 1.22 & 19.37 & 1.33 \\
\hline & $\begin{array}{l}\mathrm{Wt} \% \text { soluble solids in supernatant - } \\
\qquad \mathrm{P}_{\mathrm{SSS}}\end{array}$ & $\%$ & 27.15 & 0.80 & 31.35 & 0.86 & 34.47 & 0.74 \\
\hline & Wt. \% Total Solids - $\mathrm{P}_{\mathrm{MTS}}$ & $\%$ & 26.90 & 0.65 & 31.05 & 0.87 & 34.24 & 0.96 \\
\hline & Wt. \% Oven Dried Solids - $\mathrm{P}_{\mathrm{ODS}}$ & $\%$ & 28.61 & 0.30 & 32.93 & 0.43 & 36.37 & 0.20 \\
\hline & Wt. $\%$ UDS - $P_{\text {MUS }}$ & $\%$ & 0.14 & 0.06 & 0.23 & 0.17 & 0.36 & 0.15 \\
\hline \multirow{2}{*}{ 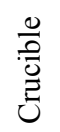 } & $\mathrm{Wt} \%$ dried total sample - $\mathrm{P}_{\mathrm{MDS}}$ & $\%$ & 26.9 & 0.06 & 31.03 & 0.11 & 34.63 & 0.19 \\
\hline & $\mathrm{Wt} \%$ total oxides $\mathrm{P}_{\mathrm{MOX}}$ & $\%$ & 12.4 & 1.15 & 15.40 & 1.19 & 19.20 & 0.87 \\
\hline
\end{tabular}

\subsubsection{LAW AN104SBS3565 Melter Feed Physical Properties}

Table 4-7 lists the results for the physical properties of the LAW AN104SBS3565 melter feeds. The general trend from most of the data was as expected, as the $\mathrm{Na}$ molarity increased, the physical properties increased in value. The only exception was that of the supernatant density, which decreased when comparing the $6.9 \mathrm{M} \mathrm{Na}$ melter feed to that of the 5.1 $\mathrm{M}$ and 6.0 M Na melter feeds. This data is not supported by the wt\% soluble solids in the supernate, which increased as the sodium molarity of the melter feed increased. The error in 


\section{WSRC-TR-2004-00232, REVISION 0 SRNL-RPP-2004-00044, REVISION 0}

the supernatant density could be due to a small sample volume of centrifuged supernatant resulting from the $6.9 \mathrm{M} \mathrm{Na}$ melter feed and the size of the graduated cylinder.

Table 4-7. Solids Analysis of LAW AN104SBS3565 Melter Feeds

\begin{tabular}{|c|c|c|c|c|c|c|c|c|c|c|}
\hline & \multirow[b]{3}{*}{ Description } & \multirow[b]{3}{*}{ Units } & \multicolumn{8}{|c|}{ Na Molarity of Starting Pretreated Waste } \\
\hline & & & \multicolumn{2}{|c|}{$\begin{array}{l}\text { 5.1M Na } 1 \text { Day } \\
\text { of Mixing }\end{array}$} & \multicolumn{2}{|c|}{$\begin{array}{l}\text { 6.0M Na } 1 \text { Day } \\
\text { of Mixing }\end{array}$} & \multicolumn{2}{|c|}{$\begin{array}{l}\text { 6.0 M Na } 7 \\
\text { Days of } \\
\text { Mixing }\end{array}$} & \multicolumn{2}{|c|}{$\begin{array}{c}\text { 6.9 M Na } 1 \\
\text { Day of Mixing }\end{array}$} \\
\hline & & & Avg. & SD & Avg. & SD & Avg. & SD & Avg. & SD \\
\hline \multirow{12}{*}{ 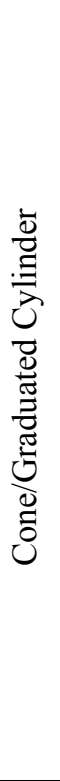 } & Bulk Density $-\rho_{B}$ & $\mathrm{~g} / \mathrm{mL}$ & 1.62 & 0.01 & 1.70 & 0.02 & 1.70 & 0.00 & 1.79 & 0.02 \\
\hline & Vol \% Settled Solids - $\mathrm{P}_{\mathrm{VSS}}$ & $\%$ & 74.2 & 0.27 & 77.7 & 0.41 & 68.36 & 0.65 & 99.28 & 0.62 \\
\hline & Density of Centrifuged Solids - $\rho_{\mathrm{CS}}$ & $\mathrm{g} / \mathrm{mL}$ & 1.85 & 0.01 & 1.89 & 0.02 & 1.95 & 0.02 & 1.85 & 0.02 \\
\hline & Vol \% Centrifuged Solids - $\mathrm{P}_{\mathrm{VCS}}$ & $\%$ & 63.6 & 0.25 & 67.4 & 0.12 & 63.31 & 0.69 & 87.27 & 1.23 \\
\hline & Wt. \% Centrifuged Solids - $\mathrm{P}_{\mathrm{MCS}}$ & $\%$ & 72.4 & 0.18 & 75.1 & 0.51 & 72.84 & 0.16 & 90.64 & 0.77 \\
\hline & Supernatant Liquid Density - $\rho_{\mathrm{S}}$ & $\mathrm{g} / \mathrm{mL}$ & 1.23 & 0.03 & $1.20^{*}$ & $0.01 *$ & 1.25 & 0.02 & 1.06 & 0.04 \\
\hline & Density of Settled Solids - $\rho_{\mathrm{SS}}$ & $\mathrm{g} / \mathrm{mL}$ & 1.73 & 0.024 & 1.79 & 0.00 & 1.89 & 0.01 & 1.75 & 0.02 \\
\hline & Wt. \% Settled Solids - $\mathrm{P}_{\text {MSS }}$ & $\%$ & 79.0 & 0.94 & 82.1 & 1.0 & 75.89 & 0.45 & 97.19 & 0.33 \\
\hline & $\begin{array}{l}\text { Wt } \% \text { soluble solids in supernatant - } \\
\text { P }_{\text {SSS }}\end{array}$ & $\%$ & 28.66 & 0.16 & $31.41^{*}$ & $0.56^{*}$ & 32.71 & 0.36 & $35.54 *$ & $1.50 *$ \\
\hline & Wt. \% Total Solids - $\mathrm{P}_{\mathrm{MTS}}$ & $\%$ & 57.18 & 0.03 & $60.91^{*}$ & $0.22 *$ & 61.07 & 0.36 & $66.05^{*}$ & $0.38^{*}$ \\
\hline & Wt. \% Oven Dried Solids - $\mathrm{P}_{\mathrm{ODS}}$ & $\%$ & 68.08 & 0.08 & $70.69^{*}$ & $0.21^{*}$ & 71.74 & 0.54 & $69.35^{*}$ & $0.11 *$ \\
\hline & Wt. \% UDS - $\mathrm{P}_{\mathrm{MUS}}$ & $\%$ & 40.00 & 0.11 & $43.13^{*}$ & $0.16^{*}$ & 42.24 & 0.35 & $47.43^{*}$ & $0.63 *$ \\
\hline \multirow{3}{*}{$\begin{array}{l}\frac{0}{0} \\
\frac{\overrightarrow{0}}{\tilde{U}}\end{array}$} & $\mathrm{Wt} \%$ dried total sample $-\mathrm{P}_{\mathrm{MDS}}$ & $\%$ & 57.51 & 0.09 & 61.47 & 0.07 & 61.70 & 0.05 & 66.31 & 0.14 \\
\hline & $\mathrm{Wt} \%$ total oxides $\mathrm{P}_{\mathrm{MOX}}$ & $\%$ & 48.16 & 0.08 & 51.48 & 0.07 & 51.77 & 0.05 & 55.39 & 0.04 \\
\hline & Wt. \% UDS P PUS-SRTC & $\%$ & 40.44 & 0.26 & $43.89^{*}$ & $0.44 *$ & 43.08 & 0.32 & $47.85^{*}$ & $1.15^{*}$ \\
\hline
\end{tabular}

*Average of two results. One sample overflowed during drying.

Results from the 1 day and 7 days of continuous mixing of the $6.0 \mathrm{M} \mathrm{Na}$ melter feed showed difference in the density of the supernatant and $\mathrm{wt} \%$ soluble solids in the supernatant. These results indicate that some of the soluble solids from the GFCs had dissolved into the supernatant during the additional 6 days of mixing.

The total solids from the graduated cone/cylinder method and the crucible method differ slightly. The wt $\%$ total solids measured using the crucible method was generally higher than that measured using the cone/cylinder method.

\subsubsection{Settling Results of LAW AN104SBS3565 Pretreated Wastes and Melter Feeds}

Settling tests were performed on the both the AN104SBS3565 pretreated wastes and melter feeds as described in the project Guidelines method (Smith 2002). First, the homogenized sample was placed into a graduated centrifuging cone that was used for the physical property determinations, after completion of the settling test. The samples were pipetted using a 5-mL 
slurry pipette into the cones and the measurement started after the cone was filled up to 7 to $10 \mathrm{~mL}$. The time after homogenization/addition was recorded and volume measurements were taken of the interface layer, which is the layer between the clear supernatant and settling solids at specified time intervals (Smith 2002).

Figure 4-3 shows the graduated centrifuge tubes used for the settling test for the pretreated waste. The recorded settling data were normalized for volume and the average normalized interface volume data is shown in Figure 4-4 and in Table 4-8. A majority of the settling occurred within 2 hours. The pretreated samples were allowed to settle for 5 days, prior to the last measurement, which envelopes the settling time in the WTP characterization procedure (Smith 2002). Note the Na molarities in Figure 4-4 are the targeted molarities. Table 4-8 provides the actual Na molarities of the pretreated wastes.

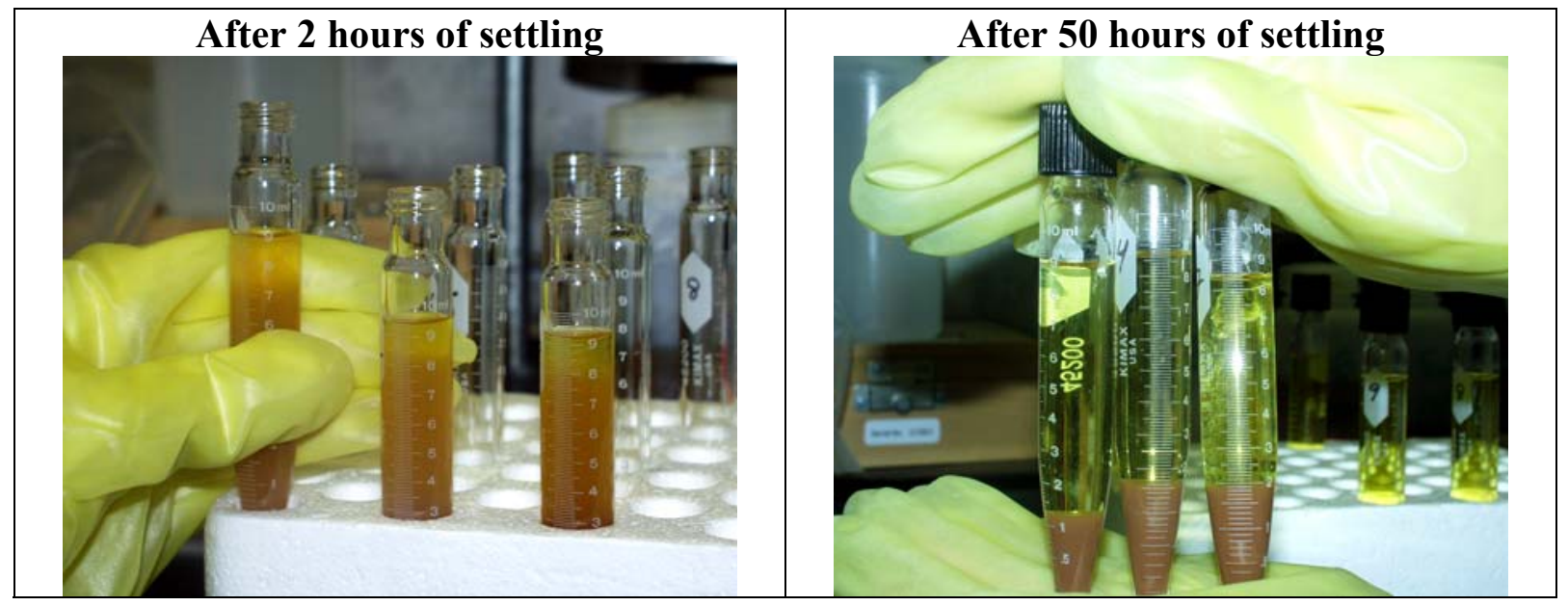

Figure 4-3. Settling of LAW AN104SBS3565 Pretreated Waste

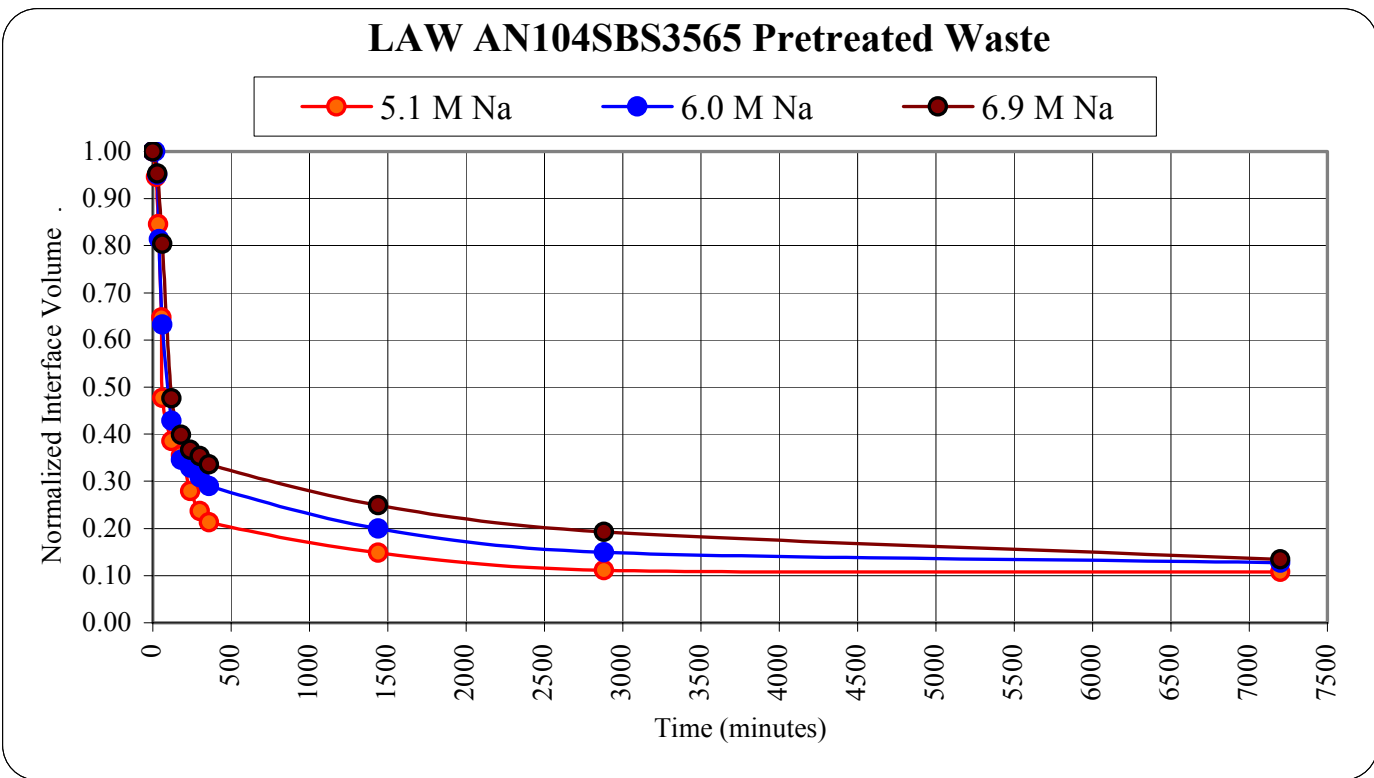

Figure 4-4. Normalized Settling Curves for LAW AN104SBS3565 Pretreated Wastes 
WSRC-TR-2004-00232, REVISION 0

SRNL-RPP-2004-00044, REVISION 0

Table 4-8. Normalized Interface Volume for LAW AN104SBS3565 Pretreated Wastes

\begin{tabular}{|c|c|c|c|c|c|}
\hline \multicolumn{2}{|c|}{$\begin{array}{c}\mathbf{5 . 1} \text { M Na } \\
\mathbf{( 4 . 7 3} \text { M Na actual) }\end{array}$} & \multicolumn{2}{c|}{$\begin{array}{c}\mathbf{6 . 0} \text { M Na } \\
\mathbf{( 5 . 6 1} \text { M Na actual) }\end{array}$} & \multicolumn{2}{c|}{$\begin{array}{c}\text { 6.9 M Na } \\
\text { T.32 M Na actual) }\end{array}$} \\
\hline Time (min) & $\begin{array}{c}\text { Normalized } \\
\text { Interface } \\
\text { Volume }\end{array}$ & $\begin{array}{c}\text { Time } \\
(\mathbf{m i n})\end{array}$ & $\begin{array}{c}\text { Normalized } \\
\text { Interface } \\
\text { Volume }\end{array}$ & Time (min) & $\begin{array}{c}\text { Normalized } \\
\text { Interface } \\
\text { Volume }\end{array}$ \\
\hline 0 & 1.000 & 0 & 1.000 & 0 & 1.000 \\
\hline 20 & 0.946 & 15 & 1.000 & 30 & 0.953 \\
\hline 35 & 0.846 & 30 & 0.950 & 60 & 0.804 \\
\hline 55 & 0.648 & 40 & 0.813 & 120 & 0.476 \\
\hline 60 & 0.477 & 60 & 0.632 & 180 & 0.399 \\
\hline 120 & 0.385 & 120 & 0.429 & 240 & 0.366 \\
\hline 180 & 0.355 & 180 & 0.346 & 300 & 0.354 \\
\hline 240 & 0.279 & 240 & 0.329 & 360 & 0.336 \\
\hline 300 & 0.236 & 300 & 0.309 & 1440 & 0.249 \\
\hline 360 & 0.213 & 360 & 0.290 & 2880 & 0.193 \\
\hline 1440 & 0.149 & 1440 & 0.200 & 7200 & 0.134 \\
\hline 2880 & 0.111 & 2880 & 0.150 & N/A & N/A \\
\hline 7200 & 0.107 & 7200 & 0.128 & N/A & N/A \\
\hline
\end{tabular}

The melter feeds normalized interface volume settling curves are shown in Figure 4-5 and the data in Table 4-9. Very little settling occurred with the $6.9 \mathrm{M} \mathrm{Na}$ melter feed over the 3 days. For the $5.1 \mathrm{M}$ and $6.0 \mathrm{M}$ Na melter feeds, most of the settling occurred within 2 hours and there seems to be little settling after that. For the $6.0 \mathrm{M}$ Na melter feed after 7 days of mixing, the data shifts down at the 2880 hrs ( 2 days) measurement, which was due to the sample being moved prior to completing the measurements. It is believed that this curve would have been between the $6.0 \mathrm{M} \mathrm{Na}$ melter feed after 1 day of mixing and the $5.1 \mathrm{M} \mathrm{Na}$ melter feed normalized settling curves. Additionally, the $6.0 \mathrm{M} \mathrm{Na}$ melter feed on day 7 settled faster than the than of the $6.0 \mathrm{M} \mathrm{Na}$ melter feed 1 day. Due to the opaque nature of these samples, the larger and denser particles settled faster than what was observed at the interface, and their quantities are unknown.

This settling data has not been corrected for wall or hindered settling effects. This data is limited only to decanting operations or to determine the amount of settled solids under gravity (it has not been shown that wall effects do not impact final settled conditions). The tapered cones are approximately 3 inches in height (with approximately the upper 1.5 inches having a constant cross-sectional area) and settling rates for decanting operations can be estimated but larger sample volumes are recommended for evaluation before implementing these numbers in plant design or operations. The data can also be used to determine if rheological measurements using standardized rotational bench scale rheometers can be utilized to measure the rheological properties of the sample based on how quickly the interface is produced relative to the time it takes to perform flow curve measurement. There are established standards for settling tests that are used for decanting, but the measuring 
WSRC-TR-2004-00232, REVISION 0

SRNL-RPP-2004-00044, REVISION 0

vessel and sample size are much larger than what was utilized here. The larger vessel size is used to minimize wall effects.

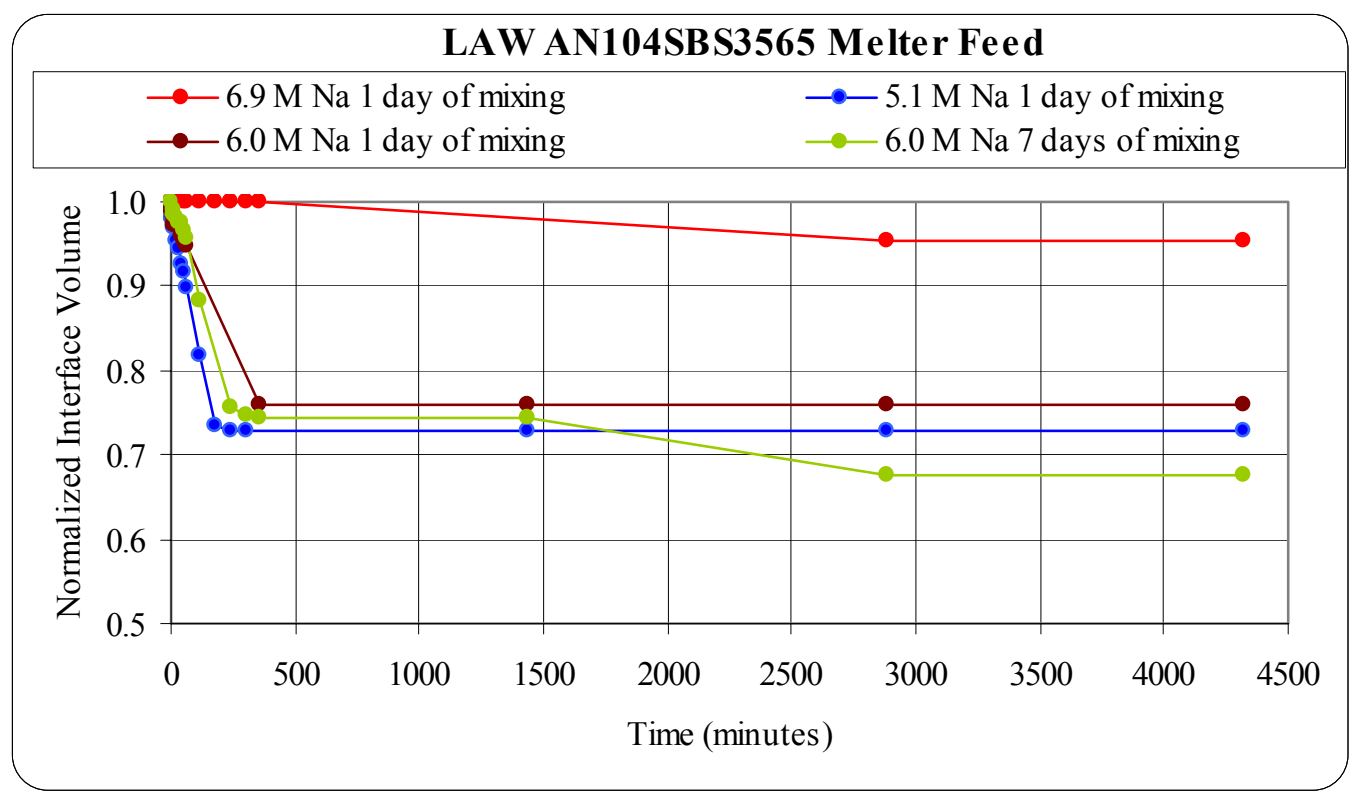

Figure 4-5. Normalized Settling Curves for LAW AN104SBS3565 Melter Feeds

Table 4-9. Normalized Interface Volume for LAW AN104SBS3565 Melter Feed

\begin{tabular}{|c|c|c|c|c|c|c|c|}
\hline \multicolumn{2}{|c|}{$\begin{array}{c}\text { 5.1 M Na after 1 } \\
\text { Day } \\
\text { mixing }\end{array}$} & \multicolumn{2}{c|}{$\begin{array}{c}\mathbf{6 . 0} \text { M Na after 1 } \\
\text { Day } \\
\text { mixing }\end{array}$} & \multicolumn{2}{|c|}{$\begin{array}{c}\text { G.0 M Na after 7 } \\
\text { Days } \\
\text { mixing }\end{array}$} & \multicolumn{2}{|c|}{$\begin{array}{c}\text { M Na after 1 } \\
\text { Day } \\
\text { mixing }\end{array}$} \\
\hline $\begin{array}{c}\text { Time } \\
\text { (min) }\end{array}$ & $\begin{array}{c}\text { Normalized } \\
\text { Interface } \\
\text { Volume }\end{array}$ & $\begin{array}{c}\text { Time } \\
(\text { min) }\end{array}$ & $\begin{array}{c}\text { Normalized } \\
\text { Interface } \\
\text { Volume }\end{array}$ & $\begin{array}{c}\text { Time } \\
(\mathbf{m i n})\end{array}$ & $\begin{array}{c}\text { Normalized } \\
\text { Interface } \\
\text { Volume }\end{array}$ & $\begin{array}{c}\text { Time } \\
\text { (min) }\end{array}$ & $\begin{array}{c}\text { Normalized } \\
\text { Interface } \\
\text { Volume }\end{array}$ \\
\hline 0 & 1.000 & 0 & 1.000 & 0 & 1.000 & 0 & 1.000 \\
\hline 5 & 0.981 & 5 & 0.990 & 10 & 0.991 & 5 & 1.000 \\
\hline 10 & 0.976 & 10 & 0.980 & 15 & 0.983 & 20 & 1.000 \\
\hline 15 & 0.969 & 15 & 0.972 & 20 & 0.981 & 50 & 1.000 \\
\hline 20 & 0.955 & 30 & 0.972 & 30 & 0.974 & 60 & 1.000 \\
\hline 30 & 0.946 & 40 & 0.960 & 40 & 0.974 & 120 & 1.000 \\
\hline 40 & 0.927 & 50 & 0.953 & 50 & 0.966 & 180 & 1.000 \\
\hline 50 & 0.918 & 60 & 0.947 & 60 & 0.957 & 240 & 1.000 \\
\hline 60 & 0.899 & 360 & 0.758 & 120 & 0.883 & 300 & 1.000 \\
\hline 120 & 0.818 & 1440 & 0.758 & 240 & 0.758 & 360 & 1.000 \\
\hline 180 & 0.735 & 2880 & 0.758 & 300 & 0.747 & 2880 & 0.955 \\
\hline 240 & 0.730 & 4320 & 0.758 & 360 & 0.743 & 4320 & 0.955 \\
\hline 300 & 0.728 & N/A & N/A & 1440 & 0.743 & N/A & N/A \\
\hline 1440 & 0.728 & N/A & N/A & 2880 & 0.676 & N/A & N/A \\
\hline 2880 & 0.728 & N/A & N/A & 4320 & 0.676 & N/A & N/A \\
\hline 4320 & 0.728 & N/A & N/A & N/A & N/A & N/A & N/A \\
\hline
\end{tabular}




\section{5 pH MEASUREMENT}

The $\mathrm{pH}$ of the LAW AN104SBS3565 pretreated wastes was not experimentally measured. However the $\mathrm{pH}$ can be estimated from the measured free hydroxide in the concentrate product of 1.08 $\mathrm{M} \mathrm{OH}^{-}$(Table 3-6). The original 7.29 M Na evaporator concentrate product was diluted to reach the targeted pretreated waste molarities as specified in Table B-2. Any of these dilution factors would result in a product with free hydroxide in the range of 0.7 to 1.1 M. These hydroxide concentrations would yield $\mathrm{pH}$ of greater than 13.5 for the pretreated wastes.

The $\mathrm{pH}$ of the LAW AN104SBS3565 melter feeds were measured using a Fisher Scientific Accumet AB15 pH meter fitted with a Fisher Scientific gel-filled, epoxy body combination electrode with $\mathrm{Ag} / \mathrm{Ag} / \mathrm{Cl}$ reference $\mathrm{pH}$ probe at ambient conditions. The $\mathrm{pH}$ measurements were performed after each melter feed was stirred at either 1 day (or for 7 days for the final 6.0M Na melter feed). The results are shown in Table 4-10. The functionality of the $\mathrm{pH}$ meter and probe were confirmed by measuring three different $\mathrm{pH}$ buffers at $\mathrm{pH}$ of 4,7 , and 10 before sample measurements were performed as directed per the WTP Guidelines (Smith 2002). These Fisher Scientific $\mathrm{pH}$ buffers are certified to within $+/-0.02 \mathrm{pH}$ units and were used within the designated expiration date listed on each buffer. There is little change in the $\mathrm{pH}$ of the $6.0 \mathrm{M}$ Na melter feed after 1 day and 7 days of mixing. The $\mathrm{pH}$ of the melter feeds shown in Table 4-10 would be lower than the $\mathrm{pH}$ of their respective pretreated wastes due to the reaction of glass formers (e.g., boric acid) with the pretreated waste. This is expected and has been noted in past SRNL experiments conducted using Hanford wastes and WTP glass formers (Hansen 2000).

Table 4-10. pH of LAW AN104SBS3565 Melter Feeds

\begin{tabular}{|c|c|}
\hline $\begin{array}{c}\text { Actual Na Molarity of Pretreated Waste } \\
\text { Concentrate Used to Prepare the Melter Feeds }\end{array}$ & $\begin{array}{c}\text { pH of the Melter } \\
\text { Feeds After Stirring }\end{array}$ \\
\hline $5.1 \mathrm{M} \mathrm{Na}$ 1 Day after mixing & 11.10 \\
\hline $6.0 \mathrm{M} \mathrm{Na}$ 1 Day after mixing & 11.41 \\
\hline $6.0 \mathrm{M} \mathrm{Na} 7$ Days after mixing & 11.36 \\
\hline $6.9 \mathrm{M} \mathrm{Na}$ 1 Day after mixing & 11.21 \\
\hline
\end{tabular}

\subsection{RHEOLOGICAL MEASUREMENTS}

Rheological properties of the LAW AN104SBS3565 pretreated wastes and melter feeds were analyzed per WTP guidelines (Smith 2002). The rheological properties of the pretreated waste and melter feeds were analyzed using controlled rate flow curves (shear stress versus shear rate). The melter feeds settled solids shear strength was determined using the vane technique. 


\subsubsection{Instrumentation}

The Haake M5/RV20 rheometer was used for all rheological measurements performed in this task. The M5 measuring head specifications are shown in Table 4-11.

Table 4-11. Haake M5 Measuring Head Specifications

\begin{tabular}{|c|c|c|}
\hline Specification & Units & Value \\
\hline Maximum Torque & N-cm & 4.9 \\
\hline Minimum Torque (recommended) & N-cm & 0.049 \\
\hline Deviation in Torque Measurement & $\%$ of maximum & $+/-0.5$ \\
\hline Maximum Speed & RPM & 500 \\
\hline Minimum Speed & RPM & 0.05 \\
\hline Error in Speed Measurement & \% of reading & $+/-0.5$ \\
\hline
\end{tabular}

\subsubsection{Flow Curve Measurements Using Concentric Geometry}

Flow curves are used to characterize the rheological properties of fluids and only the data in the laminar region of the flow curve can be used to provide these rheological properties. Flow curve measurements were obtained using a concentric (MV1) cylindrical rotor. The MV1 rotor is shown in Table 4-12. The MV 1 rotor was initially installed onto the M5 measuring head. A sample was then placed into the appropriate cup (cup dimension provided in Table 4-12) and raised into a temperature/controlled cup holder, which controlled the temperature at $25^{\circ} \mathrm{C}$ or $40^{\circ} \mathrm{C}$. The RV20 rheometer controls the rate at which the M5 measuring head spins the rotor and measures both the rotational speed and the torque (the resistance to shear). The shear stress at the wall of the rotating rotor is then calculated (internally by the Haake software) based on the product of the measured torque and geometry (A-factor) of the rotor. The shear rate of the rotating rotor is calculated as the product of the measured speed and geometry (M-factor, assumes fluid is Newtonian) of the rotor. The Afactor, $\mathrm{M}$-factor, shear rate range and the ramp up time, hold time at maximum shear rate, and ramp down time are provided in Table 4-12.

Prior to performing any flow curve measurement, the rotor and cup are inspected for visual damage that could potentially impact the flow curve measurement. National Institute of Standards and Technology (NIST) traceable Newtonian oil standards were used to verify the operability of the M5 head at a measurement temperature of $25^{\circ} \mathrm{C}$. The viscosities of the NIST traceable Newtonian oil standards at $25^{\circ} \mathrm{C}$ are shown in Table 4-13. The resulting flow curves were analyzed as a Newtonian fluid and the calculated viscosity was compared to the NIST traceable Newtonian oil standard. The rheometer was considered operable if the calculated viscosity was within $\pm 10 \%$ of the NIST traceable Newtonian oil standard viscosity as stated in Table 4-13. The measuring range of the MV1/M5 as specified by 
Haake shows a lower limit around approximately $7 \mathrm{cP}$ at a high shear rate $\left(1000 \mathrm{sec}^{-1}\right)$, but does not provide any error associated with the measurement.

Using the uncertainties provided by Haake in the measured torque and speed of the M5 measuring head (Table 4-11), the resulting viscosity, when using the S3 NIST traceable Newtonian oil standard used in this study, can vary as much as $\pm 24.7 \%$ (given a $95 \%$ or $2 \sigma$ confidence (Edwards 2003) level at a shear rate of $1000 \mathrm{sec}^{-1}$ and assuming the uncertainties provided by Haake in the torque and speed has $2 \sigma$ confidence level), but the rheometer was not considered inoperable. Measurements below $7 \mathrm{cP}$ will have to be used with a higher level of uncertainty and will be based on the actual measurement results. The requirements per the WTP characterization procedure (Smith 2002) states that the rheometer (including bob) must be within $\pm 10 \%$ of the NIST oil standard viscosity, and if not, consult the instrument manual for acceptable errors. For low viscosity fluids, using the MV1 rotor, the errors may be greater than $\pm 10 \%$.

Table 4-12. MV1 Rotor Specifications and Ramp Rates

\begin{tabular}{|c|c|c|}
\hline Design of Rotor & \multicolumn{2}{|c|}{ MV1 Rotor } \\
\hline Ra & Rotor radius (mm) & $\mathrm{R}_{\mathrm{i}}=20.04$ \\
\hline & Cup Radius (mm) & $\mathrm{R}_{\mathrm{a}}=21.0$ \\
\hline & Height of rotor (mm) & $\mathrm{L}=60$ \\
\hline & Sample Volume $\left(\mathrm{cm}^{3}\right)$ & $\mathrm{V}=34$ to 50 \\
\hline & A factor ( $\mathrm{Pa} / \%$ torque $)$ & 3.22 \\
\hline & $\mathrm{M}$ factor $\left(\mathrm{s}^{-1} / \% \mathrm{RPM}\right)$ & 11.7 \\
\hline & Measuring Range $\left(\mathrm{s}^{-1}\right)$ & $0-1000$ \\
\hline & Ramp up time (min) & 5 \\
\hline & Hold time (min) & 1 \\
\hline & Ramp down time (min) & 5 \\
\hline
\end{tabular}

Table 4-13. Cole-Parmer NIST Traceable Newtonian Oil Standard

\begin{tabular}{|c|c|c|c|c|c|}
\hline \multirow{2}{*}{$\begin{array}{c}\text { Standard } \\
\text { Type }\end{array}$} & \multicolumn{3}{|c|}{ Viscosity $(\mathrm{cP})$ at $25^{\circ} \mathrm{C}$} & \multirow{2}{*}{$\begin{array}{c}\text { Lot } \\
\text { Number }\end{array}$} & \multirow{2}{*}{$\begin{array}{l}\text { Expiration } \\
\text { Date }\end{array}$} \\
\hline & $-10 \%$ & Reported & $+10 \%$ & & \\
\hline S3 & 2.939 & 3.266 & 3.593 & F102609 & Oct. 10,2004 \\
\hline $\mathrm{S} 20$ & 25.43 & 28.25 & 31.08 & 120307 & Jan. 24, 2006 \\
\hline N35 & 45.44 & 50.49 & 55.54 & F102205 & Nov. 27, 2004 \\
\hline
\end{tabular}

The Newtonian results of the NIST traceable Newtonian oil standard are shown in Table 4-14. These results are fairly typical for measurements conducted using these NIST 
standards on the Haake viscometer with an MV1 rotor. The standard results indicate the rheometer is operating properly. Only the up curve results of the S3 oil standard are provided, since the down curves all tended to deviate away from the origin. The MV1 rotor was run with the S3 oil standard, with 1 of the 2 measurements being within $10 \%$ of the standard.

The S3 oil standard was run because the MV1 rotor was determined as the appropriate rotor to be used for the pretreated waste, which contained visible undissolved solids and was visually very thin (rheologically). SRNL typically uses the MV1 rotor when dealing with fluids that contain solids and the NV rotor when dealing with fluids that do not contain solids. As stated above, due to the uncertainties of the instrument alone, errors in the calculated viscosities can be larger than $\pm 10 \%$ for the S3 oil standard.

\section{Table 4-14. M5/MV1 Operability Checks Using NIST Traceable Viscosity Oil Standards}

\begin{tabular}{|c|c|c|c|}
\hline $\begin{array}{c}\text { NIST } \\
\text { Standard }\end{array}$ & Run Date & $\begin{array}{c}\text { Measured } \\
\text { Viscosity }(\mathbf{c P})\end{array}$ & $\begin{array}{c}\text { Viscosity within } \\
\mathbf{1 0 \%}\end{array}$ \\
\hline S3 & $2 / 11 / 04$ & 3.73 & No $(14.2 \%)$ \\
\hline S3 & $2 / 11 / 04$ & 3.28 & Yes $(0.6 \%)$ \\
\hline S20 & $3 / 23 / 04$ to $4 / 20 / 04$ & 28.35 to 28.8 & Yes \\
\hline N35 & $3 / 23 / 04$ to $4 / 20 / 04$ & 51.07 to 51.38 & Yes \\
\hline
\end{tabular}

The following rheological models Equation 4-17, Equation 4-18, Equation 4-19, and Equation 4-20) were used to fit both the up and down curves. The flow curves were fitted from 0 to $1000 \mathrm{sec}^{-1}$ using the Haake ${ }^{\text {TM }}$ software. The Newtonian model was used for both pretreated wastes and melter feeds. The other rheological models were used for the melter feeds.

\section{Equation 4-17}

Newtonian:

$\tau=\mu \cdot \dot{\gamma}$

$$
\text { Where: } \begin{aligned}
\mu & =\operatorname{viscosity}(\mathrm{Pa}-\mathrm{sec}) \\
\dot{\gamma} & =\text { shear rate }\left(\mathrm{sec}^{-1}\right) \\
\tau & =\text { shear stress }(\mathrm{Pa})
\end{aligned}
$$

\section{Equation 4-18}

Ostwald or Power Law:

$\tau=m \cdot \dot{\gamma}^{n}$

Where: $\mathrm{m}=$ the consistency coefficient $\left(\mathrm{Pa}-\mathrm{sec}^{\mathrm{n}}\right)$

$\mathrm{n}=$ the power law exponent (unit less) 


\section{Equation 4-19}

Bingham Plastic:

$$
\begin{array}{ll}
\tau=\tau_{B P}+\eta_{B P} \cdot \dot{\gamma} \\
\text { Where: } & \tau_{\mathrm{BP}}=\text { Bingham Plastic yield stress (Pa) } \\
& \eta_{\mathrm{BP}}=\text { Bingham Plastic Viscosity (or consistency) (Pa-sec) }
\end{array}
$$

\section{Equation 4-20}

$$
\begin{aligned}
& \text { Herschel-Bulkley: } \\
& \begin{aligned}
\tau=\tau_{H B} & +k \cdot \dot{\gamma}^{b} \\
\text { Where: } & \tau_{\mathrm{HB}}=\text { Herschel-Bulkley yield stress }(\mathrm{Pa}) \\
& \left.\mathrm{k}=\text { the consistency coefficient (Pa-sec }{ }^{\mathrm{n}}\right) \\
& \mathrm{b}=\text { the power law exponent (unit less) }
\end{aligned}
\end{aligned}
$$

For fluids that are not very viscous and are characterized with the MV1 rotor, Taylor vortices (secondary flow patterns that impact the laminar flow profile between the cylindrical gap of the cup and bob) start to develop and data recorded past this point must be rejected. To determine this data, Equation 4-21, taken from the WTP guidelines (Smith 2002) and rearranged, was used to determine the onset of Taylor vortices (a corresponding shear stress for the onset of Taylor vortices was calculate), for given shear rate. The Taylor vortices curves were plotted on flow curves which had data indicating Taylor vortices are present and are shown in Appendix D. Shear stress data below the calculated Taylor vortices shear stresses are rejected.

Equation 4-21

$$
\tau_{\text {reject }}<\frac{\rho \cdot\left(R_{O}-R_{i}\right)^{2.5}}{41.3 \cdot R_{i}^{0.5}} \cdot \dot{\gamma}_{i}^{2}
$$

$$
\text { Where: } \begin{aligned}
& \tau_{\text {reject }}=\text { Taylor vortices shear stress }(\mathrm{Pa}) \\
& \rho=\text { density of fluid }\left(\mathrm{kg}-\mathrm{m}^{-3}\right) \\
& \mathrm{R}_{\mathrm{o}}=\text { Cup radius }(\mathrm{m}) \\
& \mathrm{R}_{\mathrm{i}}=\text { Bob radius }(\mathrm{m}) \\
& \dot{\gamma}_{i}=\text { shear rate }\left(\mathrm{sec}^{-1}\right) \text { at bob surface }
\end{aligned}
$$

\subsubsection{Yield Stress Measurement Using Vane Geometry}

Vanes have been used (Liddell 1996, Nguyen 1983, Nguyen 1985, Barnes 2001, Saak 2001, Barnes 1990, Yoshimura 1987, Alderman 1991, Mohseni 1997, Keating 1989, Wardhaugh 1991, Yan 1997, Turian 1997, Iyer 1999) to measure the yield stress of non-Newtonian fluids as is shown in Figure 4-6. The vane is inserted into the fluid and rotated at a very slow speed. The surface area used to determine the shear stress is the surface area produced by the vane, in other words, a cylinder. It has been shown that this is a good assumption (Nguyen 1983, Nguyen 1985, Barnes 1990, Yoshimura 1987) for determining the stress of the fluid as the vane rotates through it. The derived Equation 4-22, assumes the stress is constant on all 
surfaces. The shearing due to the immersed section of the vane shaft, stress contribution of the immersed section of the shaft, and the wall effects are negligible by meeting the criteria as shown in Figure 4-6.

Equation 4-22

$$
\tau_{\text {vane }}=\frac{\Gamma}{\frac{\pi \cdot D^{3}}{2}\left(\frac{H}{D}+\frac{1}{3}\right)}=A \cdot \Gamma
$$

where $\Gamma=$ measured torque $(\mathrm{N}-\mathrm{m}$ or $\%$ torque)

$\mathrm{D}=$ diameter of vane $(\mathrm{m})$

$\mathrm{H}=$ height of vane $(\mathrm{m})$

$\mathrm{A}=$ geometric constant $\left(\mathrm{m}^{3}\right.$ or $\left.\mathrm{Pa} / \% \Gamma\right)$

$\tau_{\text {vane }}=$ shear stress $(\mathrm{Pa})$

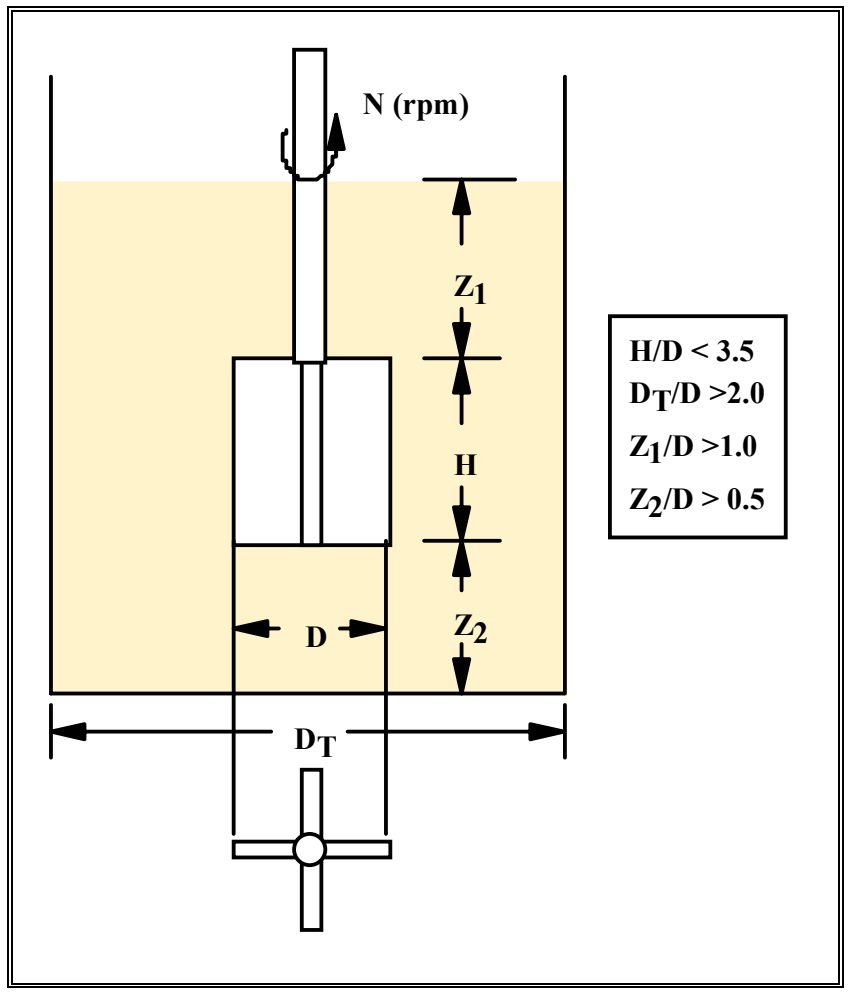

Figure 4-6. Vane Geometric Requirements

A typical stress versus time (or displacement) curve is shown in Figure 4-7. The initial response for a non-Newtonian fluid having a yield stress is typically linear and this slope is called the Hookean elastic modulus $(\mathrm{G})$. The point of departure from this linear region is called the static yield stress (Liddell 1996) when the fluid starts to transition from a fully elastic to viscoelastic behavior. At the maximum stress, the behavior of the material transitions between viscoelastic and fully viscous and is called the yield stress (known also as the dynamic yield stress). 
WSRC-TR-2004-00232, REVISION 0

SRNL-RPP-2004-00044, REVISION 0

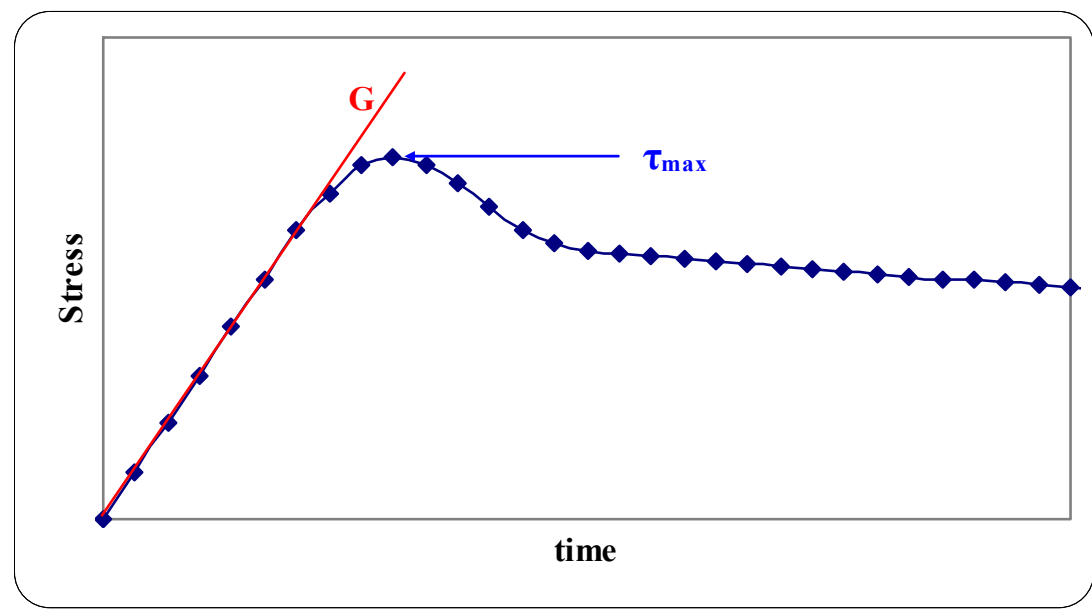

Figure 4-7. Typical Torque - Time/Displacement Curve

The vane dimensions used in this task were $\mathrm{D}=\mathrm{H}=16 \mathrm{~mm}$. The A factor for the M5 measuring head was calculated and used in the RV20 to calculate the stress from the measured torque, given the measured \%torque. The A factor used is shown in Equation 4-23.

Equation 4-23 $A=\frac{A^{\prime} \cdot \Gamma_{\max }}{100 \%}=\frac{2}{\pi \cdot(0.016 \mathrm{~m})^{3} \cdot\left(\left(\frac{16}{16}\right)+\frac{1}{3}\right)} \cdot \frac{4.9 \mathrm{~N} \cdot \mathrm{cm}}{100 \% \Gamma} \cdot \frac{\mathrm{m}}{100 \mathrm{~cm}}=57.12 \frac{\mathrm{Pa}}{\% \Gamma}$

For the vane measurements, the $\mathrm{M}$ factor was set at $1.0 \mathrm{sec}^{-1} / \% \mathrm{RPM}$. Going through the same exercise as that shown in Equation 4-18, for a rotational speed of 0.3 RPM, the controlled shear rate was $0.06 \mathrm{sec}^{-1}$ and used in the RV20. The rotational speed was also visually verified at approximately 0.3 revolutions per minute (RPM). This rotational speed is specified in the WTP guidelines (Smith 2002). The sample cup used for vane measurements had an inside diameter of $40 \mathrm{~mm}$. The samples were allowed to settle for at least 2 days prior to performing the yield stress measurement. No NIST standard is available in which the vane can be used to verify the operability of a rheometer. The M5/RV20 rheometer is verified operational via the functional check using a NIST Newtonian oil standard, using concentric geometry. The M5 head has an error of $0.5 \%$ of full torque (Table 4-11), resulting in an error of $\pm 28.56 \mathrm{~Pa}$ or $\pm 285.6 \mathrm{dynes} / \mathrm{cm}^{2}$ in the measured stress.

The yield stress, after settling at various times, is reported as the "settled solids shear strength" which is consistent with WTP terminology.

\subsubsection{LAW AN104SBS3565 Pretreated Waste Rheology Results}

Duplicate flow curves for each LAW AN104SBS3565 pretreated waste were measured at $25^{\circ} \mathrm{C}$. Only the $6.0 \mathrm{M} \mathrm{Na}$ pretreated waste was measured at $40^{\circ} \mathrm{C}$. Individual flow curve are shown in Appendix D, Figure D-1 through Figure D-24. The flow curves, specifically the up 
curves, were fitted as a Newtonian fluid, in the region where Taylor vortices are not a factor. The results are shown in Table 4-15. As expected, as the sodium molarity increases, so does the viscosity. Also, as expected, when the temperature increases, the viscosity decreases. Previous testing with simulants (Hansen 2000) indicates that viscosity reduction with increasing temperature is sodium concentration dependent. The ratio of the viscosity between $50^{\circ} \mathrm{C}$ and $25^{\circ} \mathrm{C}$ (Hansen 2000) became smaller as the sodium concentration increases, though not by much. If the $6.0 \mathrm{M} \mathrm{Na}$ pretreated waste viscosity ratio between $40^{\circ} \mathrm{C}$ and $25^{\circ} \mathrm{C}$ is used to determine the viscosity of the $5.1 \mathrm{M} \mathrm{Na}$ and $6.0 \mathrm{M} \mathrm{Na}$ pretreated wastes at $40^{\circ} \mathrm{C}$, the viscosity would be slightly under-estimated and slightly over-estimated respectively. Return curves were not fitted, due to the curve not returning through the origin, which could be due to the inertia effect on the rotor, zero is slightly drifted during the measurement, or the fact the measurement is occurring at the very low end of the torque mechanism of the M5 head.

Table 4-15. LAW AN104SBS3565 Rheology - Newtonian Results

\begin{tabular}{|c|c|c|c|c|c|c|c|}
\hline \multirow{3}{*}{\multicolumn{2}{|c|}{ Temperature }} & \multicolumn{6}{|c|}{ Na Molarity of Pretreated Waste } \\
\hline & & \multicolumn{2}{|c|}{5.1 (4.73 actual) } & \multicolumn{2}{|c|}{6.0 (5.61 actual) } & \multicolumn{2}{|c|}{6.9 (6.32 actual) } \\
\hline & & $\mu(\mathrm{Pa} \cdot \mathbf{s})$ & $\mathbf{R}^{2}$ & $\mu(\mathbf{P a} \cdot \mathbf{s})$ & $\mathbf{R}^{2}$ & $\mu(\mathrm{Pa} \cdot \mathbf{s})$ & $\mathbf{R}^{2}$ \\
\hline \multirow{3}{*}{$25^{\circ} \mathrm{C}$} & Run 1 & 0.00308 & 0.9900 & 0.00453 & 0.9970 & 0.00520 & 0.9987 \\
\hline & Run 2 & 0.00331 & 0.9893 & 0.00423 & 0.9969 & 0.00528 & 0.9990 \\
\hline & Average & 0.00320 & NA & 0.00438 & NA & 0.00524 & NA \\
\hline \multirow{4}{*}{$40^{\circ} \mathrm{C}$} & Run 1 & NM & NM & 0.00301 & 0.9919 & NM & NM \\
\hline & Run 2 & NM & NM & 0.00326 & 0.9912 & NM & NM \\
\hline & Run 3 & NM & NM & 0.00320 & 0.9890 & NM & NM \\
\hline & Average & NM & NM & 0.00316 & NA & NM & NM \\
\hline
\end{tabular}

$\mathrm{NA}=$ not applicable

\subsubsection{LAW AN104SBS3565 Melter Feed Rheology Results}

Duplicate flow curves of each LAW AN104SBS3565 melter feed were measured at $25^{\circ} \mathrm{C}$ and $40^{\circ} \mathrm{C}$. Individual melter feed flow curves are located in Appendix C, see Figure C-10 through Figure C-25. The attached flow curves are fitted with a Newtonian fluid model. The fit included up and down curves data (the hold data is excluded) and the resulting fits are shown in Table 4-16. The flow curves, both up and down curves, were individually fitted to the following rheological models using the complete shear rate range of 0 to $1000 \mathrm{sec}^{-1}$; Newtonian, Power Law, Bingham Plastic, and Hershel-Bulkley models and the results are summarized in Table 4-17 through Table 4-20.

Review of Table 4-16 shows that the Newtonian model fits the flow curves and is a representative rheological model, other than for the $6.9 \mathrm{M} \mathrm{Na}$ melter feed. Even for the 6.9 M melter feed, the Newtonian fit is not that bad. Visual inspection of the flow curves also support the Newtonian fit to the $5.1 \mathrm{M}$ and $6.0 \mathrm{M}$ Na melter feeds. 


\section{WSRC-TR-2004-00232, REVISION 0 SRNL-RPP-2004-00044, REVISION 0}

Table 4-17 through Table 4-20 contains the results using the rheological models requested by RPP-WPT. The 5.1 M Na melter feed data in Table 4-17 shows that the Newtonian model is an appropriate model to use. The other rheological models have issues, such as negative yield stresses (not realistic) and power law coefficients that are greater than one, which indicates that the slurry is rheopetic (again, not realistic). The same conclusions can be drawn for the 6.0 M Na melter feed for both 1 day and 7 days of mixing, see Table 4-18 and Table 4-19. Additionally, settling data showed that the 5.1 and 6.0 M Na melter feeds started settling within minutes of not being agitated, clearly indicating little to no yield stress in these slurries, further supporting the Newtonian results. The 6.0 M Na melter feed became thinner over time when comparing the 1 day to 7 days of mixing data, an observation that is supported by the settling data. Settling seems to slightly impact the 5.1 M Na melter feed results and has no impact on the $6.0 \mathrm{M} \mathrm{Na}$ melter feed results.

\section{Table 4-16. LAW AN104SBS3565 Melter Feed Flow Curves Fitted as a Newtonian Fluid}

\begin{tabular}{|c|c|c|c|c|c|}
\hline \multirow{3}{*}{$\begin{array}{c}\text { Actual Na } \\
\text { Molarity of } \\
\text { Pretreated } \\
\text { Waste }\end{array}$} & \multirow{3}{*}{$\begin{array}{c}\text { Measurement } \\
\#\end{array}$} & \multicolumn{4}{|c|}{ Measurement Temperature } \\
\hline & & \multicolumn{2}{|c|}{$25^{\circ} \mathrm{C}$} & \multicolumn{2}{|c|}{$40^{\circ} \mathrm{C}$} \\
\hline & & $\mu(\mathbf{P a} \cdot \mathbf{s})$ & $\mathbf{R}^{2}$ & $\mu(\mathbf{P a} \cdot \mathbf{s})$ & $\mathbf{R}^{2}$ \\
\hline \multirow{3}{*}{$\begin{array}{l}5.1 \mathrm{M}-\text { after } 1 \\
\text { day mixing }\end{array}$} & 1 & 0.0267 & 0.9791 & 0.0167 & 0.9663 \\
\hline & 2 & 0.0280 & 0.9789 & 0.0190 & 0.9784 \\
\hline & Average & 0.0273 & NA & 0.0179 & NA \\
\hline \multirow{3}{*}{$\begin{array}{l}6.0 \mathrm{M}-\text { after } 1 \\
\text { day mixing }\end{array}$} & 1 & 0.0434 & 0.9789 & 0.0313 & 0.9912 \\
\hline & 2 & 0.0454 & 0.9853 & 0.0319 & 0.9893 \\
\hline & Average & 0.0444 & NA & 0.0316 & NA \\
\hline \multirow{3}{*}{$\begin{array}{c}6.0 \mathrm{M}-\text { after } 7 \\
\text { days mixing }\end{array}$} & 1 & 0.0338 & 0.9830 & 0.0224 & 0.9791 \\
\hline & 2 & 0.0345 & 0.9892 & 0.0232 & 0.9886 \\
\hline & Average & 0.0341 & NA & 0.0228 & NA \\
\hline \multirow{3}{*}{$\begin{array}{l}6.9 \mathrm{M}-\text { after } 1 \\
\text { day mixing }\end{array}$} & 1 & 0.2753 & 0.9521 & 0.1801 & 0.9590 \\
\hline & 2 & 0.2960 & 0.9733 & 0.1850 & 0.9057 \\
\hline & Average & 0.2857 & NA & 0.1826 & NA \\
\hline
\end{tabular}

The 6.9 $\mathrm{M} \mathrm{Na}$ melter feed is slightly thixotropic, which is evident in the flow curves when inspecting the data at the maximum hold shear rate. Since the $6.9 \mathrm{M} \mathrm{Na}$ melter feed is outside the rheological (consistency and yield stress) design basis of the LAW MFPV and $\mathrm{MPV}$, no further discussion of the $6.9 \mathrm{M} \mathrm{Na}$ melter feed is necessary.

One issue that was raised during the rheological measurements, specifically for the $40^{\circ} \mathrm{C}$ measurement is that the mixing of the GFCs with the pretreated waste occurred at room temperature. If mixing were to have occurred at $40^{\circ} \mathrm{C}$ with analysis at $40^{\circ} \mathrm{C}$, the rheological results could be different, since there is a potential to dissolve glass former chemicals at elevated temperatures. No studies to date show if mixing at room temperature and performing flow curves at an elevated temperature are comparable with flow curves where mixing occurred at the elevated temperature. 
WSRC-TR-2004-00232, REVISION 0 SRNL-RPP-2004-00044, REVISION 0

Table 4-17. Rheological Results of LAW AN104SBS3565 (Pretreated Waste at 5.1 M Na) Melter Feed at $25^{\circ} \mathrm{C}$ and $40^{\circ} \mathrm{C} \mathrm{After}$ 1 Day of Mixing

\begin{tabular}{|c|c|c|c|c|c|c|c|c|}
\hline \multirow{3}{*}{ Rheological Model } & \multicolumn{4}{|c|}{$25^{\circ} \mathrm{C}$ Measurement } & \multicolumn{4}{|c|}{$40^{\circ} \mathrm{C}$ Measurement } \\
\hline & \multicolumn{2}{|c|}{ Up Curve } & \multicolumn{2}{|c|}{ Down Curve } & \multicolumn{2}{|c|}{ Up Curve } & \multicolumn{2}{|c|}{ Down Curve } \\
\hline & $1^{\text {st }}$ Meas. & $2^{\text {nd }}$ Meas. & $1^{\text {st }}$ Meas. & $2^{\text {nd }}$ Meas. & $1^{\text {st }}$ Meas. & $2^{\text {nd }}$ Meas. & $1^{\text {st }}$ Meas. & $2^{\text {nd }}$ Meas. \\
\hline \multicolumn{9}{|l|}{ Newtonian: } \\
\hline$\mu-$ viscosity (Pa-sec) & 0.0279 & 0.0292 & 0.0255 & 0.0268 & 0.0179 & 0.0199 & 0.0155 & 0.0181 \\
\hline $\mathrm{R}^{2}-$ correlation coefficient & 0.9889 & 0.9889 & 0.9845 & 0.9842 & 0.9871 & 0.9897 & 0.9846 & 0.9843 \\
\hline \multicolumn{9}{|l|}{ Ostwald (or Power Law): } \\
\hline $\mathrm{m}-$ consistency coefficient $\left(\mathrm{Pa}-\mathrm{sec}^{\mathrm{n}}\right)$ & 0.146 & 0.125 & 0.009 & 0.007 & 0.091 & 0.096 & 0.004 & 0.005 \\
\hline $\mathrm{n}$ - power law coefficient & 0.741 & 0.773 & 1.158 & 1.209 & 0.747 & 0.754 & 1.212 & 1.187 \\
\hline $\mathrm{R}^{2}-$ correlation coefficient & 0.9745 & 0.9845 & 0.9955 & 0.9984 & 0.983 & 0.974 & 0.999 & 0.997 \\
\hline \multicolumn{9}{|l|}{ Bingham Plastic (BP): } \\
\hline$\tau_{\mathrm{BP}}-\mathrm{BP}$ yield stress $(\mathrm{Pa})$ & 1.38 & 1.50 & -1.70 & -1.88 & 1.00 & 0.90 & -1.06 & -1.23 \\
\hline$\eta_{\mathrm{BP}}-\mathrm{BP}$ viscosity (Pa-sec) & 0.0258 & 0.0269 & 0.0281 & 0.0296 & 0.02 & 0.02 & 0.02 & 0.02 \\
\hline $\mathrm{R}^{2}-$ correlation coefficient & 0.9973 & 0.9963 & 0.9952 & 0.9958 & 0.9982 & 0.9966 & 0.9956 & 0.9952 \\
\hline \multicolumn{9}{|l|}{ Herschel-Bulkley (HB): } \\
\hline$\tau_{\mathrm{HB}}-\mathrm{HB}$ yield stress $(\mathrm{Pa})$ & 1.40 & 1.30 & -0.26 & -0.37 & 0.7761 & 1.1392 & -0.1747 & -0.2150 \\
\hline $\mathrm{k}-\mathrm{HB}$ consistency coefficient $\left(\mathrm{Pa}-\mathrm{sec}^{\mathrm{b}}\right)$ & 0.025 & 0.031 & 0.008 & 0.009 & 0.0218 & 0.0139 & 0.0049 & 0.0059 \\
\hline $\mathrm{b}-\mathrm{HB}$ power law coefficient & 1.0025 & 0.9778 & 1.1778 & 1.1745 & 0.9598 & 1.0408 & 1.1778 & 1.1739 \\
\hline $\mathrm{R}^{2}-$ correlation coefficient & 0.9973 & 0.9963 & 0.9984 & 0.9988 & 0.9983 & 0.9967 & 0.9988 & 0.9982 \\
\hline
\end{tabular}

Bolded data are provided for information only. Negative yield stresses are not realistic. 
Table 4-18. Rheological Results of LAW AN104SBS3565 (Pretreated Waste at $6.0 \mathrm{M} \mathrm{Na}$ ) Melter Feed at $25^{\circ} \mathrm{C}$ and $40^{\circ} \mathrm{C} \mathrm{After}$ 1 Day of Mixing

\begin{tabular}{|c|c|c|c|c|c|c|c|c|}
\hline \multirow{3}{*}{ Rheological Model } & \multicolumn{4}{|c|}{$25^{\circ} \mathrm{C}$ Measurement } & \multicolumn{4}{|c|}{$40^{\circ} \mathrm{C}$ Measurement } \\
\hline & \multicolumn{2}{|c|}{ Up Curve } & \multicolumn{2}{|c|}{ Down Curve } & \multicolumn{2}{|c|}{ Up Curve } & \multicolumn{2}{|c|}{ Down Curve } \\
\hline & $1^{\text {st }}$ Meas. & $2^{\text {nd }}$ Meas. & $1^{\text {st }}$ Meas. & $2^{\text {nd }}$ Meas. & $1^{\text {st }}$ Meas. & $2^{\text {nd }}$ Meas. & $1^{\text {st }}$ Meas. & $2^{\text {nd }}$ Meas. \\
\hline \multicolumn{9}{|l|}{ Newtonian: } \\
\hline$\mu-\operatorname{viscosity}(\mathrm{Pa}-\mathrm{sec})$ & 0.0469 & 0.0453 & 0.0438 & 0.0416 & 0.0324 & 0.0319 & 0.0317 & 0.0307 \\
\hline $\mathrm{R}^{2}-$ correlation coefficient & 0.9918 & 0.9816 & 0.9878 & 0.9901 & 0.9927 & 0.9942 & 0.9845 & 0.9911 \\
\hline \multicolumn{9}{|l|}{ Ostwald (or Power Law): } \\
\hline $\mathrm{m}-$ consistency coefficient $\left(\mathrm{Pa}-\mathrm{sec}^{\mathrm{n}}\right)$ & 0.254 & 0.130 & 0.025 & 0.018 & 0.128 & 0.135 & 0.013 & 0.029 \\
\hline $\mathrm{n}$ - power law coefficient & 0.732 & 0.843 & 1.076 & 1.130 & 0.782 & 0.769 & 0.013 & 1.002 \\
\hline $\mathrm{R}^{2}-$ correlation coefficient & 0.9867 & 0.9979 & 0.9941 & 0.9973 & 0.981 & 0.980 & 0.997 & 0.963 \\
\hline \multicolumn{9}{|l|}{ Bingham Plastic (BP): } \\
\hline$\tau_{\mathrm{BP}}-\mathrm{BP}$ yield stress $(\mathrm{Pa})$ & 2.99 & 2.08 & -2.04 & -2.46 & 1.20 & 1.14 & -1.51 & -1.62 \\
\hline$\eta_{\mathrm{BP}}-\mathrm{BP}$ viscosity (Pa-sec) & 0.0408 & 0.0438 & 0.0446 & 0.0475 & 0.03 & 0.03 & $\mathbf{0 . 0 3}$ & $\mathbf{0 . 0 3}$ \\
\hline $\mathrm{R}^{2}-$ correlation coefficient & 0.9974 & 0.9985 & 0.9962 & 0.9958 & 0.9989 & 0.9988 & 0.9972 & 0.9913 \\
\hline \multicolumn{9}{|l|}{ Herschel-Bulkley (HB): } \\
\hline$\tau_{\mathrm{HB}}-\mathrm{HB}$ yield stress $(\mathrm{Pa})$ & 1.19 & 0.64 & 0.36 & 0.05 & 1.3080 & 1.0848 & -0.6089 & 0.1336 \\
\hline $\mathrm{k}-\mathrm{HB}$ consistency coefficient $\left(\mathrm{Pa}-\mathrm{sec}^{\mathrm{b}}\right)$ & 0.094 & 0.083 & 0.012 & 0.013 & 0.0278 & 0.0316 & 0.0178 & 0.0090 \\
\hline $\mathrm{b}-\mathrm{HB}$ power law coefficient & 0.8834 & 0.9100 & 1.1888 & 1.1874 & 1.0113 & 0.9940 & 1.0872 & 1.1910 \\
\hline $\mathrm{R}^{2}-$ correlation coefficient & 0.9990 & 0.9994 & 0.9996 & 0.9993 & 0.9989 & 0.9989 & 0.9981 & 0.9954 \\
\hline
\end{tabular}

Bolded data are provided for information only. Negative yield stresses are not realistic. 
Table 4-19. Rheological Results of LAW AN104SBS3565 (Pretreated Waste at $6.0 \mathrm{M} \mathrm{Na}$ ) Melter Feed at $25^{\circ} \mathrm{C}$ and $40^{\circ} \mathrm{C} \mathrm{After}$ 7 Days of Mixing

\begin{tabular}{|c|c|c|c|c|c|c|c|c|}
\hline \multirow{3}{*}{ Rheological Model } & \multicolumn{4}{|c|}{$25^{\circ} \mathrm{C}$ Measurement } & \multicolumn{4}{|c|}{$40^{\circ} \mathrm{C}$ Measurement } \\
\hline & \multicolumn{2}{|c|}{ Up Curve } & \multicolumn{2}{|c|}{ Down Curve } & \multicolumn{2}{|c|}{ Up Curve } & \multicolumn{2}{|c|}{ Down Curve } \\
\hline & $1^{\text {st }}$ Meas. & $2^{\text {nd }}$ Meas. & $1^{\text {st }}$ Meas. & $2^{\text {nd }}$ Meas. & $1^{\text {st }}$ Meas. & $2^{\text {nd }}$ Meas. & $1^{\text {st }}$ Meas. & $2^{\text {nd }}$ Meas. \\
\hline \multicolumn{9}{|l|}{ Newtonian: } \\
\hline$\mu-\operatorname{viscosity}(\mathrm{Pa}-\mathrm{sec})$ & 0.0350 & 0.0358 & 0.0325 & 0.0332 & 0.0232 & 0.0244 & 0.0215 & 0.0223 \\
\hline $\mathrm{R}^{2}-$ correlation coefficient & 0.9892 & 0.9928 & 0.9877 & 0.9959 & 0.9919 & 0.9920 & 0.9775 & 0.9935 \\
\hline \multicolumn{9}{|l|}{ Ostwald (or Power Law): } \\
\hline $\mathrm{m}-$ consistency coefficient $\left(\mathrm{Pa}-\mathrm{sec}^{\mathrm{n}}\right)$ & 0.128 & 0.102 & 0.021 & 0.021 & 0.108 & 0.094 & 0.032 & 0.006 \\
\hline $\mathrm{n}$ - power law coefficient & 0.800 & 0.837 & 1.062 & 1.071 & 0.758 & 0.786 & 0.927 & 1.201 \\
\hline $\mathrm{R}^{2}-$ correlation coefficient & 0.9948 & 0.9970 & 0.9852 & 0.9982 & 0.979 & 0.985 & 0.940 & 0.994 \\
\hline \multicolumn{9}{|l|}{ Bingham Plastic (BP): } \\
\hline$\tau_{\mathrm{BP}}-\mathrm{BP}$ yield stress $(\mathrm{Pa})$ & 1.79 & 1.49 & -1.73 & -1.06 & 1.04 & 0.95 & -0.66 & -1.00 \\
\hline$\eta_{\mathrm{BP}}-\mathrm{BP}$ viscosity (Pa-sec) & 0.0323 & 0.0335 & $\mathbf{0 . 0 3 5 1}$ & 0.0348 & 0.02 & 0.02 & $\mathbf{0 . 0 2}$ & $\mathbf{0 . 0 2}$ \\
\hline $\mathrm{R}^{2}-$ correlation coefficient & 0.9983 & 0.9986 & 0.9949 & 0.9986 & 0.9988 & 0.9995 & 0.9800 & 0.9985 \\
\hline \multicolumn{9}{|l|}{ Herschel-Bulkley (HB): } \\
\hline$\tau_{\mathrm{HB}}-\mathrm{HB}$ yield stress $(\mathrm{Pa})$ & 0.52 & 0.25 & 0.14 & -0.34 & 1.0547 & 0.6079 & 0.5754 & -0.5437 \\
\hline $\mathrm{k}-\mathrm{HB}$ consistency coefficient $\left(\mathrm{Pa}-\mathrm{sec}^{\mathrm{b}}\right)$ & 0.069 & 0.068 & 0.009 & 0.022 & 0.0214 & 0.0309 & 0.0057 & 0.0158 \\
\hline $\mathrm{b}-\mathrm{HB}$ power law coefficient & 0.8940 & 0.8996 & 1.1878 & 1.0656 & 1.0016 & 0.9559 & 1.1960 & 1.0580 \\
\hline $\mathrm{R}^{2}-$ correlation coefficient & 0.9997 & 0.9998 & 0.9984 & 0.9991 & 0.9988 & 0.9998 & 0.9842 & 0.9988 \\
\hline
\end{tabular}

Bolded data are provided for information only. Negative yield stresses are not realistic. 
Table 4-20. Rheological Results of LAW AN104SBS3565 (Pretreated Waste at $6.9 \mathrm{M} \mathrm{Na}$ ) Melter Feed at $25^{\circ} \mathrm{C}$ and $40^{\circ} \mathrm{C} \mathrm{After}$ 1 Day of Mixing

\begin{tabular}{|c|c|c|c|c|c|c|c|c|}
\hline \multirow{3}{*}{ Rheological Model } & \multicolumn{4}{|c|}{$25^{\circ} \mathrm{C}$ Measurement } & \multicolumn{4}{|c|}{$40^{\circ} \mathrm{C}$ Measurement } \\
\hline & \multicolumn{2}{|c|}{ Up Curve } & \multicolumn{2}{|c|}{ Down Curve } & \multicolumn{2}{|c|}{ Up Curve } & \multicolumn{2}{|c|}{ Down Curve } \\
\hline & $\mathbf{1}^{\text {st }}$ Meas. & $2^{\text {nd }}$ Meas. & $1^{\text {st }}$ Meas. & $2^{\text {nd }}$ Meas. & $1^{\text {st }}$ Meas. & $2^{\text {nd }}$ Meas. & $1^{\text {st }}$ Meas. & $2^{\text {nd }}$ Meas. \\
\hline \multicolumn{9}{|l|}{ Newtonian: } \\
\hline$\mu-$ viscosity (Pa-sec) & 0.2920 & 0.3098 & 0.2589 & 0.2823 & 0.1910 & 0.2006 & 0.1694 & 0.1697 \\
\hline $\mathrm{R}^{2}-$ correlation coefficient & 0.9400 & 0.9670 & 0.9967 & 0.9988 & 0.9544 & 0.8954 & 0.9973 & 0.1697 \\
\hline \multicolumn{9}{|l|}{ Ostwald (or Power Law): } \\
\hline $\mathrm{m}-$ consistency coefficient $\left(\mathrm{Pa}-\mathrm{sec}^{\mathrm{n}}\right)$ & 1.477 & 1.060 & 0.547 & 0.647 & 1.327 & 1.546 & 0.551 & 0.665 \\
\hline $\mathrm{n}$-power law coefficient & 0.752 & 0.815 & 0.882 & 0.869 & 0.702 & 0.688 & 0.814 & 0.787 \\
\hline $\mathrm{R}^{2}-$ correlation coefficient & 0.9926 & 0.9949 & 0.9938 & 0.9927 & 0.996 & 0.991 & 0.985 & 0.993 \\
\hline \multicolumn{9}{|l|}{ Bingham Plastic (BP): } \\
\hline$\tau_{\mathrm{BP}}-\mathrm{BP}$ yield stress $(\mathrm{Pa})$ & 28.18 & 25.15 & 5.00 & 5.29 & 18.57 & 25.56 & 4.64 & 8.98 \\
\hline$\eta_{\mathrm{BP}}-\mathrm{BP}$ viscosity (Pa-sec) & 0.2496 & 0.2721 & 0.2514 & 0.2744 & 0.16 & 0.16 & 0.16 & 0.16 \\
\hline $\mathrm{R}^{2}-$ correlation coefficient & 0.9766 & 0.9920 & 0.9978 & 0.9999 & 0.9924 & 0.9657 & 0.9997 & 0.9964 \\
\hline \multicolumn{9}{|l|}{ Herschel-Bulkley (HB): } \\
\hline$\tau_{\mathrm{HB}}-\mathrm{HB}$ yield stress $(\mathrm{Pa})$ & -14.02 & 2.76 & -3.27 & 4.13 & 2.7003 & -11.2783 & 2.3916 & -0.5053 \\
\hline $\mathrm{k}-\mathrm{HB}$ consistency coefficient $\left(\mathrm{Pa}-\mathrm{sec}^{\mathrm{b}}\right)$ & 2.836 & 1.114 & 0.474 & 0.300 & 0.8255 & $\mathbf{3 . 0 7 7 3}$ & 0.2152 & 0.4667 \\
\hline $\mathrm{b}-\mathrm{HB}$ power law coefficient & 0.6637 & 0.8029 & 0.9106 & 0.9876 & 0.7736 & 0.5954 & 0.9603 & 0.8467 \\
\hline $\mathrm{R}^{2}-$ correlation coefficient & 0.9943 & 0.9965 & 0.9988 & 1.0000 & 0.9991 & 0.9935 & 0.9999 & 0.9994 \\
\hline
\end{tabular}

Bolded data are provided for information only. Negative yield stresses are not realistic. 


\section{WSRC-TR-2004-00232, REVISION 0 SRNL-RPP-2004-00044, REVISION 0}

\subsubsection{Settled Solids Vane Measurement Results}

Upon completion of the flow curve measurements, the melter feed samples in the MV cup were placed into the vane cups used for the vane measurements and additional melter feed was added to provide a sufficient zone of settled solids. The inside diameter of the cup was $40 \mathrm{~mm}$. The resulting settled solids met the criteria stated in Figure 4-6. The total height of settled solids permitted at least two vertical measurements.

For each sample, the top of the vane was submerged $16 \mathrm{~mm}$ below the surface of settled solids at the center of the cross sectional area of the cup and a measurement taken. The vane was then lowered an additional $20 \mathrm{~mm}$ and a $2^{\text {nd }}$ measurement was taken. The results are shown in Figure 4-8. In all cases, the $2^{\text {nd }}$ measurement yielded higher settled solids shear strengths. Note that the error in the vane measurement is $\pm 28.56 \mathrm{~Pa}$, which indicates that the results from the 5.1 and 6.0 M Na settled solids shear strength are not distinguishable from each other. The 6.9 $\mathrm{M} \mathrm{Na}$ settled solids shear strength were much larger compared to the other settled solids shear strengths. The 6.9 M Na settled solid shear strength results are distinguishable and indicates that the settled solids shear strength increases as the depth of the sample increases. This increase in settled solids shear strength as a function of level can not be linearly extrapolated for other depths.

Inspection of the $6.0 \mathrm{M} \mathrm{Na}$ AN104SBS3565 - 1 day of mixing results shows that there was no difference between the settled solids shear strength after 2 and 4 days of settling. The $6.0 \mathrm{M} \mathrm{Na}$ - 7 day of mixing results after 2 days of settling were no different than that of the $6.0 \mathrm{M} \mathrm{Na}-1$ day of mixing results. The maximum settled solids shear strength of the $6.0 \mathrm{M}$ Na settled solids (for any condition tested) is over a magnitude smaller than maximum settled solids shear strength $(625 \mathrm{~Pa})$ for the LAW bounding conditions (see Table 1-4). From previous testing (Hansen 2003) of an radioactive LAW AZ-102 pretreated waste mixed with approved GFCs, gelling of the material to the point where it approaches or exceeds the maximum settled solids shear strength occurred very quickly. It was noted in this report (Hansen 2003) that a hard layer was already developing within 30 minutes of settling. This combination of pretreated waste and GFCs do not seem to produce the high settled solids shear strengths of other LAW melter feeds (Hansen 2003 and Bredt 2003). Based on the results from these tests and the results from other LAW melter feeds that have extremely high settled solids shear strengths, the $6.0 \mathrm{M} \mathrm{Na}$ AN104SBS3565 melter feed settled solids shear strength is not expected to change much from the 2 and 4 day measurements after 7 days of settling.

SRNL did not perform any comparison between the AN104SBS3565 melter feed with other radioactive LAW melter feeds (Hansen 2003 and Bredt 2003) to determine possible causes for the vast differences in the settled solids shear strength. 
WSRC-TR-2004-00232, REVISION 0

SRNL-RPP-2004-00044, REVISION 0

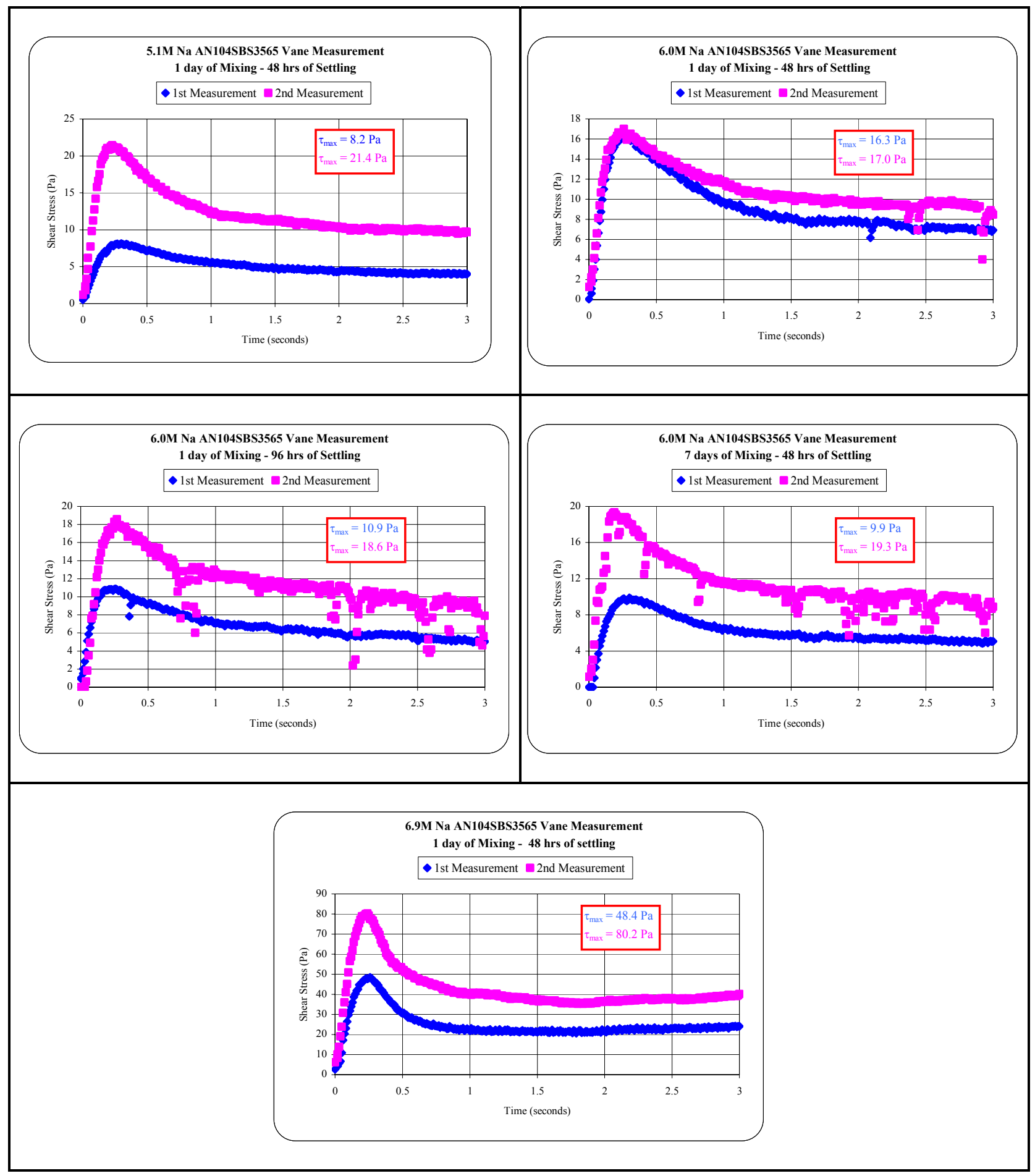

Figure 4-8. Vane Curves for LAW AN104SBS3565 Melter Feed Settled Solids ${ }^{5}$

${ }^{5} 1^{\text {st }}$ vane curve measurement is when the vane is immersed $16 \mathrm{~mm}$ into the settled solids. The $2^{\text {nd }}$ vane curve measurement is of the same sample, but the vane is immersed an additional $20 \mathrm{~mm}$ below the $1^{\text {st }}$ measurement prior to the measurement being taken. 


\section{WSRC-TR-2004-00232, REVISION 0 SRNL-RPP-2004-00044, REVISION 0}

\subsection{PARTICLE SIZE DISTRIBUTION}

A Microtrac X-100 particle size analyzer was used to measure the particle size distribution (PSD) of these samples. Prior to analysis, the sample was diluted using a filtered simulant supernatant with approximately the same molarity as that of the sample. The Microtrac X-100 particle size analyzer measures the particle diameters by measuring the scattered light from a laser beam projected through a stream of the fluid carrying the diluted sample particles. The amount and direction of the light scattered by the particles is measured by an optical detector array and then analyzed to determine the size distribution of the particles. The Microtrac X-100 range is nominally 0.12 to $704 \mu \mathrm{m}$. It should be noted that this instrument does not have sonication (ultrasonic energy that breaks up agglomerations) capabilities; hence, no PSD measurements were taken with sonication. The Microtrac X-100 has software that was utilized to calculate the mean number, mean area, mean volume and number and volume distribution data for standards, pretreated wastes and melter feeds.

The X-100 was functionally checked at the beginning and at the end of the melter feed PSD measurements using NIST traceable particle size standards from Duke Scientific Corporation. These particle size standards are polystyrene micro spheres dispersed in a $1 \mathrm{mM}$ potassium chloride solution. The particle size standards were diluted using de-ionized water as the suspending fluid and a nominal flow rate of $40 \mathrm{~mL} / \mathrm{s}$. The X-100 instrument was set to 'transparent' mode with the particle refractive index equal to 1.59 and particle shape as spherical. The small NIST standard particles had a diameter of $39.6 \mu \mathrm{m} \pm 0.8 \mu \mathrm{m}$ uncertainty with $\pm 3.6 \mu \mathrm{m}$ standard deviation. The larger NIST standard particle had a diameter of $496 \mu \mathrm{m} \pm 10 \mu \mathrm{m}$ uncertainty with $\pm 24 \mu \mathrm{m}$ standard deviation.

Each standard was run in triplicate with a measuring time of 30 seconds per measurement. The average of three measurements is reported. The standards were run before (initial) and after (final) the pretreated wastes and melter feeds were analyzed. The Microtrac X-100 calculated the mean volume diameter and the mean number diameter and the results for the standards are presented in Table 4-21. The mean diameter of a distribution represents the centroid of the distribution. Instrument functionality is typically verified by comparing the calculated mean volume diameter from measuring the PSD of the certified standard to the certified values of the standards. The calculated value is recommended to be within $\pm 10 \%$ of the standard for ideal instrumentation functionality verification as stated in Smith 2002.

Table 4-21 shows the calculated mean diameters on a number and volume basis for both the smaller and larger standards. The calculated mean volume diameters are within $\pm 10 \%$ of the standard mean diameter for all measurements. Several of the number basis values are well below the mean diameters of the standards. This could be the result of slight degradation of a relatively small number of the standard particles. 
WSRC-TR-2004-00232, REVISION 0 SRNL-RPP-2004-00044, REVISION 0

Table 4-21. Summary of Particle Size Data for Standards

\begin{tabular}{|c|c|c|c|c|c|}
\hline \multicolumn{2}{|c|}{ NIST Traceable Particle Size Standard } & \multicolumn{4}{|c|}{$\begin{array}{c}\text { Measured Mean Diameters on a Number and } \\
\text { Volume Basis }(\mu \mathrm{m})\end{array}$} \\
\hline \multirow[b]{2}{*}{ Description } & \multirow{2}{*}{$\begin{array}{c}\text { Mean } \\
\text { Diameter } \\
(\mu \mathrm{m})\end{array}$} & \multicolumn{2}{|c|}{ Initial Measurements } & \multicolumn{2}{|c|}{ Final Measurements } \\
\hline & & $\begin{array}{c}\text { Number } \\
(\mathbf{m n})^{*}\end{array}$ & $\begin{array}{l}\text { Volume } \\
\text { (mv)* }\end{array}$ & $\begin{array}{c}\text { Number } \\
\text { (mn)* }\end{array}$ & $\begin{array}{l}\text { Volume } \\
\text { (mv)* }\end{array}$ \\
\hline \multicolumn{6}{|c|}{ Standards Run For Pretreated Waste } \\
\hline Duke Scientific Standard 2040A & $39.6 \pm 0.8$ & $0.234 * *$ & 40.59 & 38.46 & 40.49 \\
\hline Duke Scientific Standard 4350A & $497 \pm 10$ & $0.194 * *$ & 545.0 & 523.9 & 534.5 \\
\hline \multicolumn{6}{|c|}{ Standards Run For Melter Feed } \\
\hline Duke Scientific Standard 2040A & $39.6 \pm 0.8$ & 37.77 & 40.46 & $0.146^{* *}$ & 40.63 \\
\hline Duke Scientific Standard 4350A & $497 \pm 10$ & $0.178 * *$ & 542.6 & $0.194 * *$ & 550.5 \\
\hline
\end{tabular}

After the operability of the Microtrac X-100 was confirmed, the pretreated waste and melter feed measurements were performed. These melter feeds were diluted using an LAW AN-104 pretreated waste simulant as the suspending fluid with a nominal flow rate of $40 \mathrm{~mL} / \mathrm{s}$. The AN-104 pretreated waste simulant used to dilute the melter feeds is shown in Appendix E, Table E-1, for a $4.74 \mathrm{M}$ Na solution. The AN-104 pretreated waste simulant was diluted to the calculated Na molarity of the melter feed (Table 1-8) and filtered through a $0.2 \mu \mathrm{m}$ filter prior to being used to dilute the melter feed samples. The Microtrac X-100 was set to 'Absorb' mode with particle shape, particle refractive index and fluid refractive index unspecified. Five homogenized subsets of this sample were then analyzed, using a 60 second cycle time, through the Microtrac X-100. The average of the five measurements is reported in Table 4-22.

Table 4-22 summarizes the mean and median data for the melter feed PSD for both volume and number basis. Additional information for the three different melter feeds, including volume distribution, cumulative volume distribution, number distribution, cumulative number distribution plots, numerical data, and Microtrac X-100 operating conditions is presented in Appendix E.

From the data in Appendix E, the volume basis data for the pretreated waste had particles that ranged in size between 1.156 to $31.11 \mu \mathrm{m}$. For melter feed, the particles ranged between 0.172 to $352.0 \mu \mathrm{m}$. This data indicates a very tight band for the pretreated waste as compared to the melter feed. On a number basis, the pretreated waste particles ranged between 1.156 to $26.16 \mu \mathrm{m}$ and the melter feed particles ranged between 0.204 to $22.0 \mu \mathrm{m}$. The number band is slightly smaller for the melter feed. This indicates there are a lot of small particles in the melter feed, but they take up a very small volume as compared to the larger particles. The melter feeds have bimodal or tri-modal distributions of particles, which are not uncommon or unexpected of melter feeds using individual glass formers that range widely in particle size distribution and can be seen in the raw PSD data located in Appendix E. 
WSRC-TR-2004-00232, REVISION 0

SRNL-RPP-2004-00044, REVISION 0

Table 4-22. Summary of Particle Size Distribution Data for AN104SBS3565 Pretreated Waste and Melter Feeds

\begin{tabular}{|c|c|c|c|c|}
\hline \multirow{2}{*}{ Fluid } & \multicolumn{2}{|c|}{ Volume $(\mu \mathbf{m})$} & \multicolumn{2}{c|}{ Number $(\mu \mathrm{m})$} \\
\cline { 2 - 5 } & Mean $(\mathbf{m v})^{*}$ & Median$* *^{* *}$ & Mean $(\mathbf{m n})^{*}$ & Median** $^{* * 1}$ \\
\hline Pretreated Waste & 10.41 & 10.06 & 3.086 & 2.359 \\
\hline $\begin{array}{c}\text { 5.1M Na Melter Feed - 1 day of } \\
\text { mixing }\end{array}$ & 23.58 & 13.79 & 0.674 & 0.517 \\
\hline $\begin{array}{c}\text { 6.0M Na Melter Feed - 1 day of } \\
\text { mixing }\end{array}$ & 27.52 & 15.90 & 0.691 & 0.528 \\
\hline $\begin{array}{c}\text { 6.0M Na Melter Feed - 7 days of } \\
\text { mixing }\end{array}$ & 15.68 & 9.034 & 0.667 & 0.511 \\
\hline $\begin{array}{c}\text { 6.9M Na Melter Feed - 1 day of } \\
\text { mixing }\end{array}$ & 21.39 & 11.73 & 0.643 & 0.467 \\
\hline
\end{tabular}

* Mean volume (mv) is the mean diameter on volume distribution and mean number $(\mathrm{mn})$ is mean diameter on number distribution - see explanation note a bottom of Figure E-1.

** Median values are the $50 \%$ Percentiles that indicate $50 \%$ of all particles were below, and $50 \%$ of all particles were above this value on either the volume distribution or the number distribution.

No baseline PSD measurements were made of the filtered AN-104 pretreated waste simulant. The impact of solids smaller than $0.2 \mu \mathrm{m}$ in the AN-104 pretreated waste simulant would bias the number results in the direction of smaller particle size data for the melter feed. From a numbers perspective, many of the individual GFCs have number distributions that contain particles that are also in this range (Schumacher 2003). This would have had little impact on the volume distribution, which is typically the data used for performing engineering calculations relative to settling.

\subsection{COMPOSITIONAL DATA}

\subsubsection{Glass Former Chemical Batch Makeup}

The VSL batch sheet (Table 4-2) was used and the actual quantities are provided in Appendix C, Table C-2. The moisture contents of the individual GFCs, other than Borax and sugar were measured and also reported in Table $\mathrm{C}-2$. Table $\mathrm{C}-1$ contains the vendors oxide composition of the individual GFCs (Schumacher 2003). Given the blend composition of GFCs, moisture contents and oxide composition of the individual GFCs, the oxide and elemental composition of the blended GFCs was determined and the results are provided in Table 4-23. The sum of oxides in Table 4-23 do not add up to $100 \%$, due to waters of hydration in the borax, water in the minerals themselves, and sugar in the batched GFCs. 
WSRC-TR-2004-00232, REVISION 0

SRNL-RPP-2004-00044, REVISION 0

Table 4-23. Oxide and Elemental Composition of Blended LAWA137 Batch

\begin{tabular}{|c|c|c|c|c|c|c|c|}
\hline Oxide & $\begin{array}{c}\text { Wt\% oxide } \\
\text { in Batch }\end{array}$ & Element & $\begin{array}{c}\text { Wt\% } \\
\text { element } \\
\text { in Batch }\end{array}$ & Oxide & $\begin{array}{c}\text { Wt\% oxide } \\
\text { in Batch }\end{array}$ & Element & $\begin{array}{c}\text { Wt\% } \\
\text { element } \\
\text { in Batch }\end{array}$ \\
\hline $\mathrm{Al}_{2} \mathrm{O}_{3}$ & 2.935 & $\mathrm{Al}$ & 1.554 & $\mathrm{Na}_{2} \mathrm{O}$ & 0.001 & $\mathrm{Na}$ & 0.001 \\
\hline $\mathrm{B}_{2} \mathrm{O}_{3}$ & 10.490 & $\mathrm{~B}$ & 3.259 & $\mathrm{NiO}$ & 0.011 & $\mathrm{Ni}$ & 0.009 \\
\hline $\mathrm{CaO}$ & 5.350 & $\mathrm{Ca}$ & 3.824 & $\mathrm{SO}_{4}$ & 0.007 & $\mathrm{~S}$ & 0.003 \\
\hline $\mathrm{Cr}_{2} \mathrm{O}_{3}$ & 0.006 & $\mathrm{Cr}$ & 0.004 & $\mathrm{SiO}_{2}$ & 48.384 & $\mathrm{Si}$ & 22.629 \\
\hline $\mathrm{Fe}_{2} \mathrm{O}_{3}$ & 5.547 & $\mathrm{Fe}$ & 3.880 & $\mathrm{TiO}_{2}$ & 1.225 & $\mathrm{Ti}$ & 0.734 \\
\hline $\mathrm{K}_{2} \mathrm{O}$ & 0.007 & $\mathrm{~K}$ & 0.006 & $\mathrm{U}_{3} \mathrm{O}_{8}$ & 0.002 & $\mathrm{U}$ & 0.002 \\
\hline $\mathrm{Li} \mathrm{L}_{2} \mathrm{O}$ & 2.618 & $\mathrm{Li}$ & 1.216 & $\mathrm{~V}_{2} \mathrm{O}_{5}$ & 0.006 & $\mathrm{~V}$ & 0.003 \\
\hline $\mathrm{MgO}$ & 1.503 & $\mathrm{Mg}$ & 0.907 & $\mathrm{ZnO}_{n}$ & 3.211 & $\mathrm{Zn}$ & 2.580 \\
\hline $\mathrm{MnO}$ & 0.017 & $\mathrm{Mn}$ & 0.014 & $\mathrm{ZrO}_{2}$ & 3.176 & $\mathrm{Zr}$ & 2.351 \\
\hline
\end{tabular}

\subsubsection{LAW AN104SBS3565 Pretreated Waste Composition}

The initial 5.1, 6.0 and 6.9 M Na LAW AN104SBS3565 pretreated wastes were prepared based on the sodium concentration of the 7.29 M Na AN104SBS3656 pretreated waste. The composition of the 7.29 M Na AN104SBS3656 pretreated waste is provided in Appendix B, Table B-1. The prepared pretreated wastes were analyzed for sodium molarity using both AA and ICP-ES, and it was determined that the 7.29 M Na pretreated waste was not at this sodium concentration. The average calculated starting sodium molarity of the $7.29 \mathrm{M}$ Na pretreated waste was $6.75 \mathrm{M} \mathrm{Na}$. The 7.29 $\mathrm{M}$ Na pretreated waste elemental concentration data was corrected to $6.75 \mathrm{M} \mathrm{Na}$ and results are shown in Table B-4. The composition of the 5.1, 6.0 and 6.9 $\mathrm{M}$ Na LAW AN104SBS3565 pretreated wastes were determined using Equation 4-24 and information provided in Appendix B, Table B-4 and Table B-6. The results are shown in Table 4-24.

Equation 4-24 $\quad \psi_{i}=\psi_{6.75 M} \frac{V_{6.75 M}}{V_{i}}$

where: $\psi_{6.75 \mathrm{M}}=$ volumetric concentration of element or compound in the $6.75 \mathrm{M} \mathrm{Na}$

AN104SBS3656 pretreated waste

$\psi_{i}=$ volumetric concentration of element or compound in the various concentrated

AN104SBS3656 pretreated waste

$\mathrm{V}_{6.75 \mathrm{M}}=$ volume of $6.75 \mathrm{M} \mathrm{Na}$ AN104SBS3656 pretreated waste used

$\mathrm{V}_{\mathrm{i}}=$ volume of various concentrated AN104SBS3565 made 
WSRC-TR-2004-00232, REVISION 0

SRNL-RPP-2004-00044, REVISION 0

Table 4-24. Elemental Composition of LAW AN104SBS3565 Pretreated Wastes

\begin{tabular}{|c|c|c|c|c|c|c|c|}
\hline \multirow[b]{2}{*}{ Element } & \multicolumn{3}{|c|}{ Concentration (mg/L) } & \multirow[b]{2}{*}{ Element } & \multicolumn{3}{|c|}{ Concentration $(\mathrm{mg} / \mathrm{L})$} \\
\hline & $5.1 \mathrm{M} \mathrm{Na}$ & $6.0 \mathrm{M} \mathrm{Na}$ & $6.9 \mathrm{M} \mathrm{Na}$ & & $5.1 \mathrm{M} \mathrm{Na}$ & $6.0 \mathrm{M} \mathrm{Na}$ & $6.9 \mathrm{M} \mathrm{Na}$ \\
\hline $\mathrm{Al}$ & 13513 & 15872 & 18436 & $\mathrm{P}$ & 375 & 440 & 511 \\
\hline $\mathrm{B}$ & 521 & 612 & 711 & $\mathrm{~Pb}$ & 23.0 & 27.0 & 31.3 \\
\hline $\mathrm{Be}$ & 0.1 & 0.2 & 0.2 & $\mathrm{~S}$ & 1813 & 2130 & 2474 \\
\hline $\mathrm{Ca}$ & 34.3 & 40.3 & 46.8 & $\mathrm{Sb}$ & 38.0 & 44.6 & 51.8 \\
\hline $\mathrm{Ce}$ & 17.5 & 20.6 & 23.9 & $\mathrm{Si}$ & 181 & 212 & 246 \\
\hline $\mathrm{Cr}$ & 148 & 174 & 202 & $\mathrm{Sn}$ & 31.6 & 37.1 & 43.1 \\
\hline $\mathrm{Fe}$ & 11.8 & 13.9 & 16.1 & $\mathrm{Sr}$ & 7.8 & 9.2 & 10.7 \\
\hline $\mathrm{K}$ & 3221 & 3783 & 4394 & $\mathrm{Ti}$ & 5.0 & 5.8 & 6.8 \\
\hline $\mathrm{Li}$ & 22.9 & 26.9 & 31.2 & $\mathrm{U}$ & 52.9 & 62.1 & 72.1 \\
\hline $\mathrm{Mg}$ & 5.2 & 6.1 & 7.1 & $\mathrm{~V}$ & 3.9 & 4.5 & 5.3 \\
\hline Mo & 37.9 & 44.5 & 51.7 & $\mathrm{Zn}$ & 51.8 & 60.9 & 70.7 \\
\hline $\mathrm{Na}$ & 117280 & 137751 & 160001 & $\mathrm{Zr}$ & 2.6 & 3.1 & 3.6 \\
\hline
\end{tabular}

\subsubsection{LAW AN104SBS3565 Melter Feed Composition}

The LAW AN104SBS3565 melter feed elemental compositions were also calculated. The mass of each element contributed by the pretreated waste was determined by multiplying the volume (Table B-6) of pretreated waste with the corresponding pretreated waste in Table 4-24. The mass of each element contributed by the GFCs were determined by multiplying the actual mass of used blended GFCs (Table 4-3) by the $\mathrm{wt} \%$ of the element in the GFC batch (Table 4-23). The volume of melter feed was determined by summing the masses of blended GFCs (Table 4-3) and pretreated waste (Table B-6) and dividing this total mass by the density of the melter feed (Table 1-8). The mass of each element was then divided by the volume of melter feed, and the results are shown in Table 4-25. 
WSRC-TR-2004-00232, REVISION 0

SRNL-RPP-2004-00044, REVISION 0

Table 4-25. Elemental Composition of AN104SBS3565 Melter Feeds

\begin{tabular}{|c|c|c|c|c|c|c|c|}
\hline \multicolumn{8}{|c|}{ Sodium Molarities shown are for Pretreated Waste } \\
\hline \multirow[b]{2}{*}{ Element } & \multicolumn{3}{|c|}{ Concentration (mg/L) } & \multirow[b]{2}{*}{ Element } & \multicolumn{3}{|c|}{ Concentration (mg/L) } \\
\hline & $5.1 \mathrm{M} \mathrm{Na}$ & 6.0 M Na & $6.9 \mathrm{M} \mathrm{Na}$ & & $5.1 \mathrm{M} \mathrm{Na}$ & 6.0 M Na & $6.9 \mathrm{M} \mathrm{Na}$ \\
\hline $\mathrm{Al}$ & 20888 & 23528 & 26153 & $\mathrm{Ni}$ & 65.3 & 74.2 & 81.4 \\
\hline $\mathrm{B}$ & 24014 & 27275 & 29956 & $\mathrm{P}$ & 266 & 297 & 335 \\
\hline $\mathrm{Be}$ & 0.10 & 0.12 & 0.13 & $\mathrm{~Pb}$ & 16.3 & 18.2 & 20.5 \\
\hline $\mathrm{Ca}$ & 27767.1 & 31546.0 & 34633.2 & $\mathrm{~S}$ & 1312 & 1463 & 1650 \\
\hline $\mathrm{Ce}$ & 12 & 14 & 16 & $\mathrm{Sb}$ & 27.0 & 30.1 & 34.0 \\
\hline $\mathrm{Cr}$ & 134 & 150 & 168 & $\mathrm{Si}$ & 164299 & 186659 & 204927 \\
\hline $\mathrm{Fe}$ & 28157 & 31990 & 35120 & $\mathrm{Sn}$ & 22.5 & 25.1 & 28.3 \\
\hline $\mathrm{K}$ & 2335 & 2604 & 2936 & $\mathrm{Sr}$ & 5.6 & 6.2 & 7.0 \\
\hline $\mathrm{Li}$ & 8838 & 10041 & 11024 & $\mathrm{Ti}$ & 5329 & 6054 & 6646 \\
\hline $\mathrm{Mg}$ & 6584 & 7480 & 8212 & $\mathrm{U}$ & 52.1 & 58.4 & 65.4 \\
\hline $\mathrm{Mn}$ & 102 & 115 & 127 & $\mathrm{~V}$ & 24.5 & 27.8 & 30.6 \\
\hline Mo & 26.9 & 30.0 & 33.9 & $\mathrm{Zn}$ & 18754 & 21306 & 23392 \\
\hline $\mathrm{Na}$ & 83443 & 93036 & 104944 & $\mathrm{Zr}$ & 17058 & 19380 & 21276 \\
\hline
\end{tabular}

\subsubsection{Calculating Processing Variable for AN104SBS3565 Melter Feed}

A LAW vitrification rheological bounding condition is the Hedstrom number for a 2 inch inside diameter pipe and the bounding Hedstrom number $\left(10^{8}\right)$ is stated in Table 1-4. The Hedstrom number is calculated using Equation 4-25. The Hedstrom number was calculated for a 2 inch pipe and using the appropriate data from Table 1-8, Table 1-9 and Table 1-10. The results for the Hedstrom numbers are shown are shown in Table 1-9 and Table 1-10.

Equation 4-25

$$
N_{H e}=\frac{D_{i} \rho_{m} \tau_{B P}}{\eta_{B P}}
$$

Where: $\quad \mathrm{D}_{\mathrm{i}}=$ inside pipe diameter $(\mathrm{m})$

$$
\rho_{\mathrm{m}}=\text { density of slurry }\left(\mathrm{Kg} / \mathrm{m}^{3}\right)
$$

Calculations were also performed to determine the mass and volumetric feed rates necessary to yield 30 and 60 MT of glass per day. Data from Table 1-8 were used to determine those feed rates necessary to achieve 30 and 60 metric tons of glass per day and the results are shown in Table 1-5.

Equation 4-26 $\quad \dot{m}=\frac{\hat{P} \cdot 100 \%}{P_{M O X}}$

Where: $\quad \hat{P}=$ glass production rate (MT glass/day)

$\dot{m}=$ mass flow rate of melter feed $(\mathrm{kg} / \mathrm{min})$

$\mathrm{P}_{\mathrm{MOX}}=\mathrm{wt}^{\%} \%$ total oxides (see Equation 4-15) 
WSRC-TR-2004-00232, REVISION 0

SRNL-RPP-2004-00044, REVISION 0

Equation 4-27 $\dot{Q}=\frac{\dot{m}}{\rho_{m}}$

Where: $\quad \dot{Q}=$ volumetric flow rate of melter feed (liters $/ \mathrm{min}$ ) 
WSRC-TR-2004-00232, REVISION 0

SRNL-RPP-2004-00044, REVISION 0

This page intentionally left blank. 


\subsection{CRUCIBLE-SCALE VITRIFICATION}

The purpose of the crucible vitrification portion of this work scope was to melt the AN-104 glass in a crucible-scale furnace test using a glass formulation recipe based on AN-104 plus recycle characterization and then cool the melt using the Container Centerline Cooling (CCC) Curve rate supplied by WTP. The container centerline cooling was specified from actual canister testing as detailed in the LAW CCC Data Memorandum from WTP shown in Appendix F. The product glass was to be subjected to characterization and product testing, but this scope of work was removed per WTP Test Exception direction as described in the Section 1.2.

The glass formulation recipe developed for the AN-104 mixed with recycle was based on the initial characterization of the $4.74 \mathrm{M} \mathrm{Na}$ AN-104 pretreated waste and $0.097 \mathrm{M} \mathrm{Na}$ SBS A3 recycle. The $4.74 \mathrm{M} \mathrm{Na}$ AN-104 pretreated waste was blended with the $0.097 \mathrm{M} \mathrm{Na}$ SBS A3 recycle at volume ratio of $35 \% \mathrm{AN}-104$ to $65 \% \mathrm{SBS}$ and is referred to as AN104SBS3565. The AN104SBS3565 pretreated waste data (Table 3-1 and Table 3-2) was submitted to WTP from SRNL for glass recipe development by VSL. Table 4-2 shows the resulting glass formulation labeled LAWA137 that was received by SRNL from WTP and VSL. The formulation as received from WTP is on a 1-L basis of $6 \mathrm{M} \mathrm{Na}$ to produce a total of $1.27 \mathrm{~kg}$ of glass with the sodium oxide target in final glass equal to $14.64 \mathrm{wt} \%$. From this information, 211.7 grams of glass is made from 1 mole of Na. To yield 55 grams of glass, the minimum necessary for CCC testing, 0.260 moles of $\mathrm{Na}$ is required. As discussed in Section 4.3.2, the actual final concentration of the AN104SBS3565 pretreated waste was determined to be $6.75 \mathrm{M} \mathrm{Na}$. The volume of $6.75 \mathrm{M}$ Na pretreated waste and mass of GFCs (199.7 grams GFCs/mole Na, section 4.2) necessary for this glass yield is $38.6 \mathrm{~mL}$ and 51.92 grams.

Glass was produced from the melter feed slurry obtained by mixing the prescribed amount of glass forming minerals with the $6.75 \mathrm{M} \mathrm{Na}$ AN104SBS3565 pretreated waste. A listing of the WTP approved GFCs and the analysis of the GFC blend for this AN-104 A137 glass recipe are presented in Sections 4.2 and 4.8.1. Crucible-scale vitrifications were performed using a 600$\mathrm{mL}$ crucible $(95 \% \mathrm{Pt} / 5 \% \mathrm{Au})$ located inside a quartz glass offgas system inside of a Deltech furnace. The offgas system was employed to trap hazardous constituents from the vitrification process, and this residue is returned to Hanford.

The vitrification test involved loading the 600-mL crucible with the blended AN104SBS3565 melter feed made for this task. This pretreated waste and GFCs were briefly mixed by hand using a stir rod before placing the melter feed into the quartz offgas system inside of the furnace. The heating sequence involved first slow heating to evaporate off the liquid in the slurry, followed by calcining and then melting at $1150^{\circ} \mathrm{C}$. Melted glass samples were cooled per the WTP-approved LAW CCC profile. The heating sequence plot of temperature versus time and the CCC profile is shown in Figure 5-1. Note that the setpoint temperatures (solid diamonds) and the furnace readout temperatures (solid squares) were essentially the same (data points overlaid on graph of Figure 5-1) during all phases of the vitrification and cooling process. 


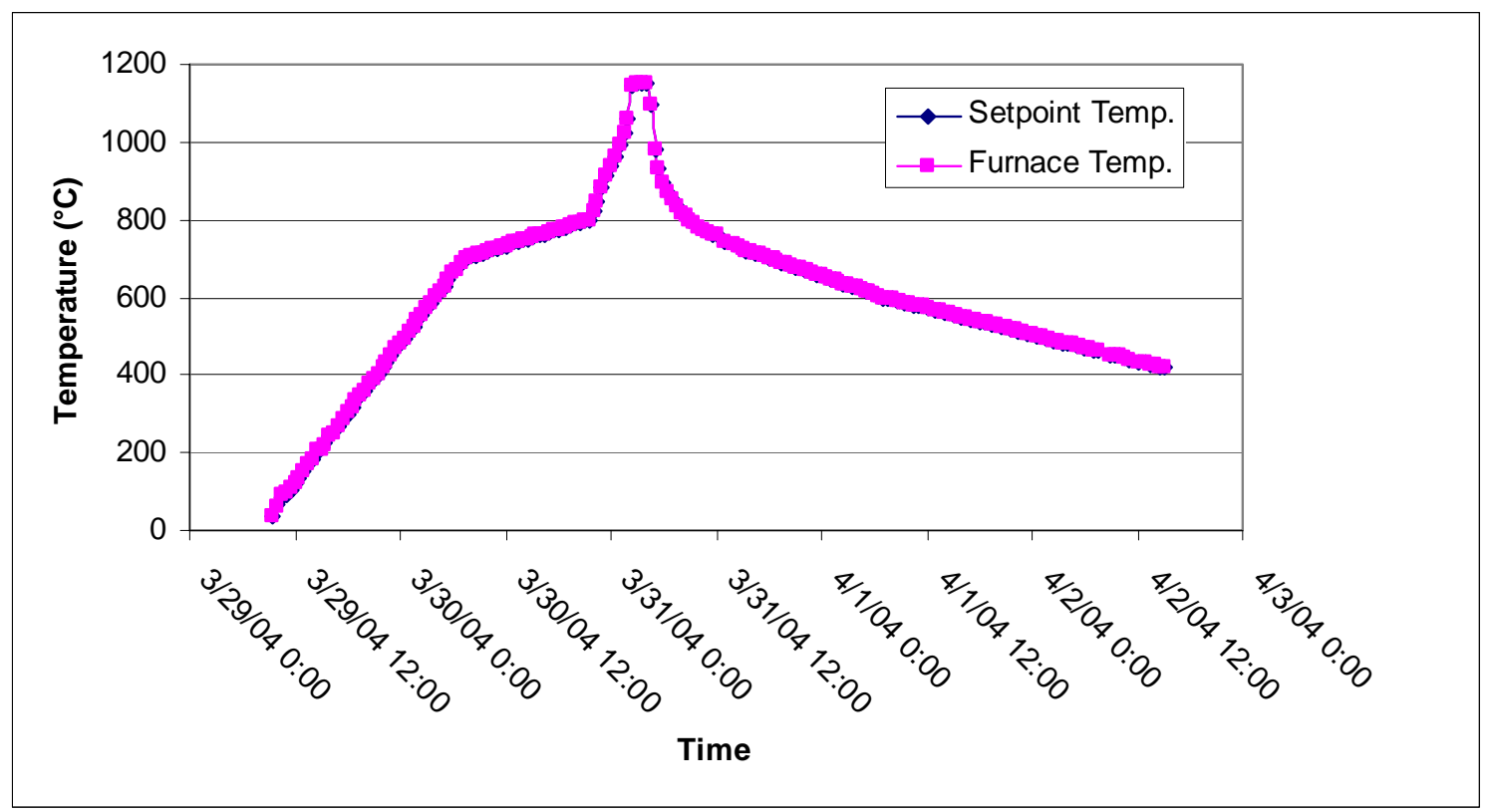

Figure 5-1. Temperature Profile vs. Time for AN104SBS3565 Crucible Glass Vitrification with CCC

The final AN104SBS3565 CCC glass 55 gram monolith from the crucible vitrification is shown in Figure 5-2 and Figure 5-3 along with the 600-mL Pt crucible. Figure 5-2 is the glass monolith underside or bottom surface that was in contact with the Pt crucible.

Figure 5-3 shows the top surface of the same glass monolith. A small amount of white crystalline surface material is seen on the bottom edge of the glass top-surface in Figure 5-3. This crystalline material derives from the quartz offgas system that contained the glass during vitrification and cooling. This small piece of crystalline quartz 'scaled' off of the inside of the glass offgas system likely during the cooling cycle since the material seemed to be slightly embedded in the top surface of the glass. These figures show the AN104SBS3565 glass to be dark and shiny, indicating a continuous amorphous-phase glass product using the CCC curve supplied by WTP.

The radionuclide content of the AN104SBS3565 glass can be estimated from the measured radionuclides in the pretreated waste, the volume of pretreated waste used in the glass recipe, and the final amount of target glass. Table 5-1 shows the various radionuclide concentrations in the pretreated waste measured in this study (from Table 3-2 and Table 3-6) and from the filtration study (Table 2-7 from Poirier 2003). The data in these tables were converted to the final $6.75 \mathrm{M} \mathrm{Na}$ basis that was used in the crucible-scale glass production. The actual volume of $6.75 \mathrm{M} \mathrm{Na}$ AN104SBS3565 pretreated waste used was $39 \mathrm{~mL}$, and the target glass product of 55.6 grams were used to calculate the curies per gram of glass. These calculations assume no loss of any radionuclide during the vitrification process. Final conversion of Ci/g glass to $\mathrm{Ci} / \mathrm{m}^{3}$ glass assumed the LAW AN104SBS3565 glass density of approximately 2.68 $\mathrm{g} / \mathrm{cc}$ as was measured on recent AZ-102 LAW glasses (Crawford 2004). 
WSRC-TR-2004-00232, REVISION 0

SRNL-RPP-2004-00044, REVISION 0

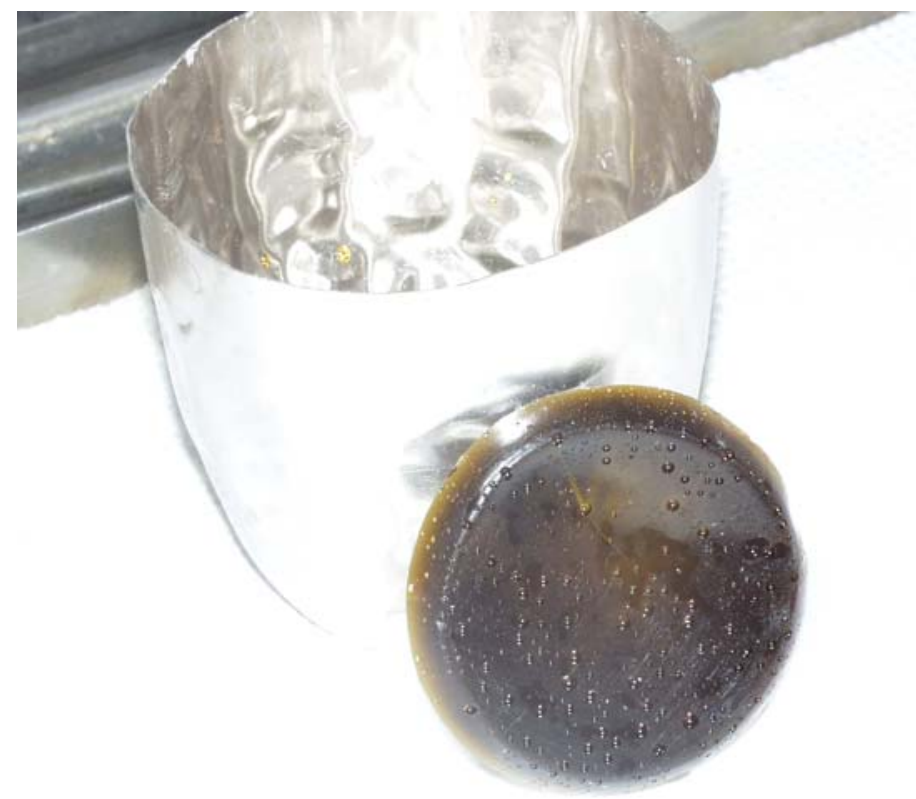

Figure 5-2. Bottom Surface of AN104SBS3565 Glass from Crucible Vitrification

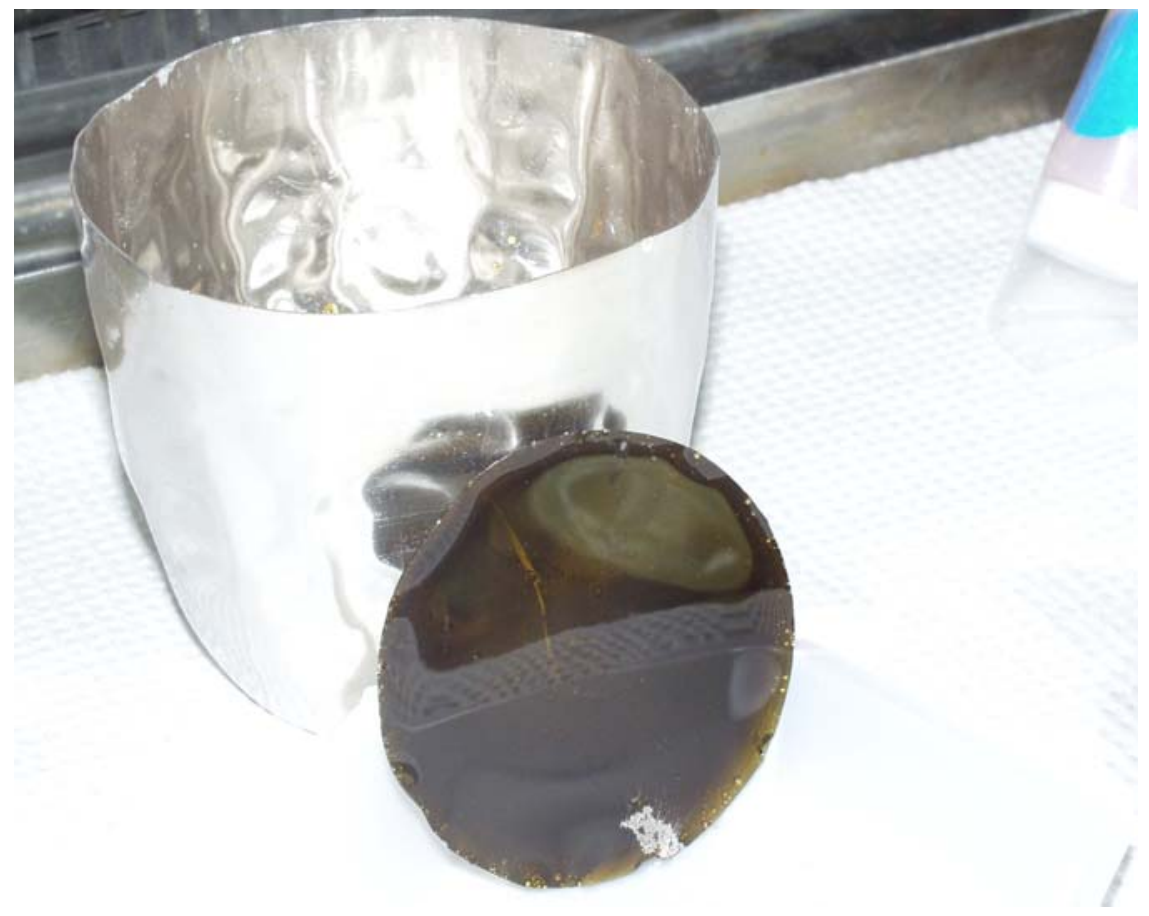

Figure 5-3. Top Surface of AN104SBS3565 Glass from Crucible Vitrification 


\section{WSRC-TR-2004-00232, REVISION 0 SRNL-RPP-2004-00044, REVISION 0}

Table 5-1 shows that using Sr-90 values from previous filtration testing yielding higher estimated Sr-90 levels $\left(0.22 \mathrm{Ci} / \mathrm{m}^{3}\right)$ in the product glass by about $3 \mathrm{X}$ versus the values measured in this study $\left(0.068 \mathrm{Ci} / \mathrm{m}^{3}\right)$. Both of these estimated levels are well below the 20 $\mathrm{Ci} / \mathrm{m}^{3}$ limit as specified in the WTP Contract (WTP Contract, 2004). It is likely that Sr-90 measured in the previous filtration testing on the AN-104 filtrate was biased high due to the relatively high amount of Cs-137 in the filtrate at that time, i.e., before ion exchange processing to remove Cs-137 was carried out. The beta emitting component of Cs-137 can interfere with the separation and counting method used to measure Sr-90. The estimated level of Cs-137 in the AN104SBS3565 glass is very low due to the ion exchange pretreatment of the AN-104 waste. The estimated level in the glass of $0.0008 \mathrm{Ci} / \mathrm{m}^{3}$ is orders of magnitude below the contract limit of $3 \mathrm{Ci} / \mathrm{m}^{3}$. The Tc-99 levels predicted in the glass agree well using either the filtration study $\left(0.27 \mathrm{Ci} / \mathrm{m}^{3}\right)$ or current measured Tc-99 values $\left(0.21 \mathrm{Ci} / \mathrm{m}^{3}\right)$, and these levels are within the WTP contract limits.

Table 5-1. Estimated Radionuclides in AN-104 Glass

\begin{tabular}{|c|c|c|c|c|c|c|}
\hline & & Concentration & $\begin{array}{l}\text { Concentrate } \\
\text { (4.7 M basis) }\end{array}$ & $\begin{array}{c}\text { Final } \\
\text { Concentrate } \\
\text { (6.75 M basis) } \\
\end{array}$ & $\begin{array}{c}\text { Glass } \\
\text { Concentration }\end{array}$ & $\begin{array}{c}\text { Final Glass } \\
\text { Concentration }\end{array}$ \\
\hline Source* & Radionuclide & $\mu \mathrm{Ci} / \mathrm{mL}$ & $\mu \mathrm{Ci} / \mathrm{mL}$ & $\mu \mathrm{Ci} / \mathrm{mL}$ & $\mathrm{Ci} / \mathrm{g}$ & $\mathrm{Ci} / \mathrm{m}^{3}$ \\
\hline T3-2 & Total Alpha & $<2.04 \mathrm{E}-04$ & $<2.03 \mathrm{E}-04$ & $<2.88 \mathrm{E}-04$ & $<2.02 \mathrm{E}-10$ & $<0.0005$ \\
\hline T3-2 & Total Beta & $1.63 \mathrm{E}-01$ & $1.62 \mathrm{E}-01$ & $2.30 \mathrm{E}-01$ & $1.62 \mathrm{E}-07$ & 0.433 \\
\hline $\mathrm{T} 2-7$ & Sr-90 & $9.50 \mathrm{E}-02$ & $8.30 \mathrm{E}-02$ & $1.18 \mathrm{E}-01$ & $8.27 \mathrm{E}-08$ & 0.222 \\
\hline T3-2 & Sr-90 & $2.57 \mathrm{E}-02$ & $2.55 \mathrm{E}-02$ & $3.63 \mathrm{E}-02$ & $2.55 \mathrm{E}-08$ & 0.0682 \\
\hline T3-7 & Cs-137 & $2.82 \mathrm{E}-04$ & $2.82 \mathrm{E}-04$ & $4.01 \mathrm{E}-04$ & $2.81 \mathrm{E}-10$ & 0.0008 \\
\hline T3-2 & Tc-99 & $1.02 \mathrm{E}-01$ & $1.01 \mathrm{E}-01$ & $1.44 \mathrm{E}-01$ & $1.01 \mathrm{E}-07$ & 0.271 \\
\hline $\mathrm{T} 2-7$ & Tc-99 & $9.20 \mathrm{E}-02$ & $8.03 \mathrm{E}-02$ & $1.14 \mathrm{E}-01$ & $8.01 \mathrm{E}-08$ & 0.215 \\
\hline T2-7 & $\mathrm{Pu}-238$ & 4.33E-04 & $3.78 \mathrm{E}-04$ & $5.38 \mathrm{E}-04$ & $3.77 \mathrm{E}-10$ & 0.0010 \\
\hline T2-7 & $\mathrm{Pu}-239 / 240$ & $3.00 \mathrm{E}-04$ & $2.62 \mathrm{E}-04$ & $3.73 \mathrm{E}-04$ & $2.61 \mathrm{E}-10$ & 0.0007 \\
\hline $\mathrm{T} 2-7$ & Am-241 & $<1.60 \mathrm{E}-03$ & $<1.40 \mathrm{E}-03$ & $<1.99 \mathrm{E}-03$ & $<1.39 \mathrm{E}-09$ & $<0.0037$ \\
\hline T3-7 & Co-60 & $8.52 \mathrm{E}-05$ & $8.52 \mathrm{E}-05$ & $1.21 \mathrm{E}-04$ & $8.50 \mathrm{E}-11$ & 0.0002 \\
\hline $\mathrm{T} 2-7$ & Eu-154 & $4.63 \mathrm{E}-03$ & $4.05 \mathrm{E}-03$ & $5.75 \mathrm{E}-03$ & $4.04 \mathrm{E}-09$ & 0.0108 \\
\hline $\mathrm{T} 2-7$ & Eu-155 & $4.27 \mathrm{E}-03$ & $3.73 \mathrm{E}-03$ & $5.30 \mathrm{E}-03$ & $3.72 \mathrm{E}-09$ & 0.0010 \\
\hline T3-7 & Sb-126 & $1.88 \mathrm{E}-04$ & $1.88 \mathrm{E}-04$ & $2.67 \mathrm{E}-04$ & $1.88 \mathrm{E}-10$ & 0.0005 \\
\hline T3-7 & Sn-126 & $2.81 \mathrm{E}-04$ & $2.81 \mathrm{E}-04$ & $4.00 \mathrm{E}-04$ & $2.80 \mathrm{E}-10$ & 0.0008 \\
\hline Source & Radionuclide & $\mu \mathrm{g} / \mathrm{mL}$ & $\mu \mathrm{g} / \mathrm{mL}$ & $\mu \mathrm{g} / \mathrm{mL}$ & $\mu \mathrm{g} / \mathrm{mL}$ & wt\% \\
\hline T2-7 & U-235 & $4.60 \mathrm{E}-02$ & $4.02 \mathrm{E}-02$ & $5.71 \mathrm{E}-02$ & $4.01 \mathrm{E}-08$ & $4.0 \mathrm{E}-04$ \\
\hline T2-7 & U-238 & $7.40 \mathrm{E}+00$ & $6.46 \mathrm{E}+00$ & $9.19 \mathrm{E}+00$ & $6.45 \mathrm{E}-06$ & $6.4 \mathrm{E}-02$ \\
\hline
\end{tabular}

*Sources, T3-2 = Table 3-2 of this document, WSRC-TR-2004-00232; T3-7 = Table 3-7 of this document, WSRC-TR-2004-00232; T2-7 = Table 2-7 of (Poirier 2003) 
WSRC-TR-2004-00232, REVISION 0

SRNL-RPP-2004-00044, REVISION 0

\subsection{CONCLUSIONS}

Conclusions are located in the abstract. 
WSRC-TR-2004-00232, REVISION 0

SRNL-RPP-2004-00044, REVISION 0

This page intentionally left blank. 
WSRC-TR-2004-00232, REVISION 0

SRNL-RPP-2004-00044, REVISION 0

\subsection{REFERENCES}

Adu-Wusu, K., 2003, and Hassan, N. M., "Cesium Ion Exchange Using AN-104 Supernate (U)," WSRC-TR-2003-00311, SRT-RPP-00147, Westinghouse Savannah River Company, Aiken, SC, October 2003.

Alderman, N. J., 1991, Meeten, G. H., and Sherwood, J. D., "Vane Rheometry of Bentonite Gel," Journal of Non-Newtonian Fluid Mechanics, Vol. 91, pp 291-310, 1991

Baich, M. A. et al., 2003, "Waste Treatment Plant LAW Evaporation: Antifoam Performance (U)”, WSRC-TR-2003-00216, SRT-RPP-2003-00095, Westinghouse Savannah River Company, Aiken, SC, August 2003.

Barnes, H. A., 1990, and Carnali, J. O., "The Vane-In-Cup as a Novel Rheometer Geometry for Shear Thinning and Thixotropic Materials," Journal of Rheology, Vol. 34, pp 841-866, 1990

Barnes, H.A., 2001, and Nguyen, Q.D., "Review Rotating Vane Rheometry - A Review," Journal of Non-Newtonian Fluid Mechanics, Vol. 98, pp 1-14, 2001

Barnes, C.D., 2003, W. E. Daniel, J. E. Laurinat, "Waste Feed Evaporation Physical Properties Modeling," WSRC-TR-2003-00172, SRT-RPP-2003-00073, Westinghouse Savannah River Company, Aiken, SC, July 2003.

Bredt, P.R., 2003, B.W. Arey, E. C. Buck, E. D. Jenson, B. K. McNamara, A. P. Poloski, and R. G. Swoboda, "Rheological and Physical Properties of AP-101 LAW Pretreated Waste and Melter Feed", PNWD-3279, March 2003, Pacific Northwest National Laboratory, Richland, WA.

Crawford, C.L., 2003, and T. B. Calloway, "Task Technical and Quality Assurance Plan for AN-104 LAW (Envelope A) Evaporation, Rheology, Vitrification and Product Testing (U)," WSRC-TR-2003-00107, SRT-RPP-2003-00028, Westinghouse Savannah River Co., Aiken, SC, June 24, 2003.

Crawford, C. L. et al., 2004, "Final Report on Crucible-Scale Radioactive Vitrification and Product Testing of Waste Env. B (AZ-102) Low Activity Waste Glass (U)," WSRC-TR2003-00536, SRT-RPP-2003-00237, Westinghouse Savannah River Company, Aiken, SC, March 2004.

Crowder, M. L., 2003, Crawford, C. L., "Evaporation of Pretreated Hanford Tank AW-101 Sample Mixed with Recycle,” WSRC-TR-2003-00218, Rev. 0, SRT-RPP-2003-00156, August, 2003, Westinghouse Savannah River Company, Aiken, SC 29808.

Crowder, M.L., 2004, J.L. Siler, T.B. Calloway, M.A. Lee, J.D. Clark, and C.L. Crawford, "Antifoam Testing with AN-104/SBS Blended Solution," WSRC-VM-2004-00555, SRNLRPP-2004-00065, Westinghouse Savannah River Co., Aiken, SC, August, 2004. 
WSRC-TR-2004-00232, REVISION 0

SRNL-RPP-2004-00044, REVISION 0

Daniel, W.E., 2003, “Modeling Treated LAW Feed Evaporation”, WSRC-TR-2003-00269, Rev. 0., SRT-RPP-2003-00125, October 2003, Westinghouse Savannah River Company, Aiken, SC 29808

Duratek, 2003, 'RPP Pilot Melter Subenvelope A3 Variation Test Plan', TP-PLT-016/TP24590-01-00005, Rev. 0, 2003, Columbia, MD.

Edwards, T., Email to Hansen, E., Subject “Re: Follow Up," Westinghouse Savannah River Company, Aiken, SC, August 28, 2003.

Hansen, E. K., 2000, and Calloway, T. B., "Characterization of Simulant LAW Envelope A, B, and C with Glass Formers," WSRC-TR-2000-00298, Rev. 0, Westinghouse Savannah River Company, Aiken, SC, August 2000.

Hansen, E. K., 2003, and Crawford, C. L., "Rheological and Physical Properties of Hanford Radioactive LAW AZ-102 Pretreated Waste and Melter Feed," WSRC-TR-2003-00390, SRT-RPP-2003-00185, Rev. 0, November 2003, Westinghouse Savannah River Company, Aiken, SC.

Hay, M. S., 2003, Coleman, C. J., Martin, K. B., Fellinger, T. L., 'Compositing, Homogenization, and Characterization of Samples from Hanford Tank 241-AN-104 (U)," WSRC-TR-2003-00479, SRT-RPP-00222, Westinghouse Savannah River Company, Aiken, SC, December 2003.

Iyer, R.S., 1999, and Stanmore B., "The Effect of Water Absorption and the Role of Fines on the Yield Stress Of Dense Fly Ash Slurries," Cement and Concrete Research, Volume 29, pp 765-767, 1999.

Josephs, J. E., 2003, Stone, M. E., Calloway, T. B., Eibling, R. E., Barnes, C. D., Hansen, E. K., "Treated LAW Feed Evaporation: Physical Properties and Solubility Determination (U)," WSRC-TR-2003-00119, SRT-RPP-2003-00039, Westinghouse Savannah River Company, Aiken, SC, March 2003.

Keating, J., 1989, and Hannant, D. J., "The Effect of Rotation Rate on Gel Strength and Dynamic Yield Strength of Thixotropic Oil Well Cements Measured Using a Shear Vane," Journal of Rheology, Vol. 33, pp 1011-1020, 1989.

Larson, D., 9/27/04, “Test Exception to Test Specification 24590-LAW-TSP-RT-02-015, Rev. 0; AN-104 LAW (Envelope A) Rheology, Vitrification and Product Testing, WSRCTR-2003-00107, Task Technical and Quality Assurance Plan for AN-104 LAW (Envelope A) Evaporation, Rheology, Vitrification and Product Testing," Test Specification Number: 24590-LAW-TEF-RT-04-0001, Rev. 0, RPP-WTP, Richland, WA

Liddell, P.V., 1996, and Boger D.V., "Yield Stress Measurements with the Vane," Journal of Non-Newtonian Fluid Mechanics, Vol. 63, pp 235-261, 1996. 
WSRC-TR-2004-00232, REVISION 0

SRNL-RPP-2004-00044, REVISION 0

Longwell, R.L., Email attachment, July 8, 2003, Unreleased model results from Nov. 19, 2002, May 11, 2003 and May 15, 2003, RPP-WTP, Richland, WA.

Matlack, K. S., et al., 2003, "DuraMelter 100 Sub-Envelope Changeover Testing Using LAW Sub-Envelopes A3 and C2 Feeds in Support of the LAW Pilot Melter," VSL-03T34101, Rev. 0, January 2003, Vitreous State Laboratory, The Catholic University of America, Washington, DC.

Mohseni, M., 1997, Kautola, H., and Allen D.G., "The Viscoelastic Nature of Filamentous Fermentation Broths and Its Influence on the Directly Measured Yield Stress”, Journal of Fermentation and Bioengineering, Vol. 83, pp 281-286, 1997.

Muller, I. S., 2004, Goloski, L., Pegg, I. L., "LAW Glass Formulation to Support AN-104 Actual Waste Testing," VSL-04R4470-1, March 25, 2004, Vitreous State Laboratory, The Catholic University of America, Washington, DC.

Nguyen, Q.D., 1983, and Boger D.V., "Yield Stress Measurements for Concentrated Suspensions," Journal of Rheology, Vol. 27, pp 321-349, 1983.

Nguyen, Q.D., 1985, and Boger D.V., "Direct Yield Stress Measurement with the Vane Method," Journal of Rheology", Vol. 29, pp 335-347, 1985.

Poirier, M. R., 2003, Burket, P. B., Siler, J. L., "Filtration of a Hanford AN-104 Sample," WSRC-TR-2003-00295, SRT-RPP-00137, Westinghouse Savannah River Company, Aiken, SC, September 2003.

Poloski, A., 2003, Smith, H., Smith, G., and Calloway B., WTP-RPT-075, Rev. 0, "Interim Report: Development of LAW and HLW Vitrification Physical Property Bounding Conditions and Simulant Verification Criteria," Pacific Northwest National Laboratory, Richland, WA, March 2003

Poloski, A., 2004, Smith, H., Smith, G. and Calloway T., "Technical Basis for LAW Vitrification Stream Physical and Rheological Properties Bounding Conditions", WTP-RPT098, Rev. 0, Pacific Northwest National Laboratory, Richland, WA, February 2004

Prindiville, K., 12/4/03, “Test Exception to AN-104 LAW (Envelope A) Rheology, Vitrification and Product Testing, 24590-LAW-TSP-RT-02-015, Rev. 0, Task Technical and Quality Assurance Plan for AN-104 LAW (Envelope A) Evaporation, Rheology, Vitrification and Product Testing, WSRC-TR-2003-00107', Test Exception Number: 24590WTP-TEF-RT-03-077, Richland, WA.

Saak, A.W., 2001, Jennings, H.M., and Shah S.P., "The Influence of Wall Slip on Yield Stress and Viscoelastic Measurements of Cement Paste," Cement and Concrete Research, Vol. 31, pp 205-212, 2001. 
WSRC-TR-2004-00232, REVISION 0

SRNL-RPP-2004-00044, REVISION 0

Schumacher, R., 2003, "Characterization of HLW and LAW Glass Formers - Final Report," WSCR-TR-2002-00282, Rev. 1, Westinghouse Savannah River Company, Aiken, SC, July 15,2003 ..

Sidibe, A., 2003, "AN104 LAW (Envelope A) Rheology, Vitrification and Product Testing," 24590-LAW-TSP-RT-02-015, Rev. 0, February 3, 2003, RPP-WTP, Richland, WA.

Smith, G.L., 2002, and Prindiville, K., "Guidelines for Performing Chemical, Physical, and Rheological Properties Measurements,” 24590-WTP-GPG-RTD-001, Rev. 0, RPP-WTP, Richland, WA, May 20, 2002.

Turian, R. M., 1997, Ma, T. W., Hsu, F.L.G., and Sung, D. J., "Characterization, Settling, and Rheology of Concentrated Fine Particle Mineral Slurries," Powder Technology, Vol. 93, pp. 219-233, 1997.

Wardhaugh, L. T., 1991, and Boger, D. V., "The Measurement and Description of the Yielding Behavior of Waxy Crude Oil,” Journal of Rheology, Vol. 35, pp 1121-1165, 1991.

WTP Contract, DE-AC27-01RV14136, Section C, Modification Number M041, September 2004.

Yan, J., 1997, and Jame, A.E., 'The Yield Surface of Viscoelastic and Plastic Fluids in a Vane Viscometer," Journal of Non-Newtonian Fluid Mechanics, Vol. 70, pp 237-253, 1997.

Yoshimura, A. S., 1987, and Prud'Homme, P.K., "A Comparison of Techniques for Measuring Yield Stresses,” Journal of Rheology, Vol. 31, pp 699-710, 1987. 
WSRC-TR-2004-00232, REVISION 0

SRNL-RPP-2004-00044, REVISION 0

\section{APPENDIX A. SOLIDS ANALYSES, PARTICLE SIZE DETERMINATION, AND BLEND RATIO DATA}


WSRC-TR-2004-00232, REVISION 0 SRNL-RPP-2004-00044, REVISION 0

Table A-1. Major and Trace Components in Digested Solids from SBS A3 Recycle and AN104SBS3565 Pretreated Waste

\begin{tabular}{|c|c|c|}
\hline \multirow{2}{*}{ Analyte } & 0.0970 M Na SBS A3 Recycle & 4.74 M Na AN104SBS3565 \\
\hline & $\boldsymbol{\mu g} / \mathbf{g}(\mathbf{p p m})$ & $\mu \mathrm{g} / \mathrm{g}(\mathrm{ppm})$ \\
\hline $\mathrm{Al}$ & 13095 & 79600 \\
\hline $\mathrm{Ag}$ & $<40.0$ & $<49.0$ \\
\hline B & 365 & $<809$ \\
\hline $\mathrm{Ba}$ & 110 & 94 \\
\hline $\mathrm{Ca}$ & 18670 & 8731 \\
\hline $\mathrm{Cd}$ & $<2.00$ & $<147$ \\
\hline $\mathrm{Ce}$ & $<95.0$ & 779 \\
\hline Co & 10 & NM \\
\hline $\mathrm{Cr}$ & 1660 & 1000 \\
\hline $\mathrm{Cu}$ & 45 & $<123$ \\
\hline $\mathrm{Fe}$ & 11050 & 4145 \\
\hline Gd & NM & $<98.0$ \\
\hline $\mathrm{K}$ & 2535 & $<10900$ \\
\hline $\mathrm{La}$ & 90 & $<110$ \\
\hline $\mathrm{Li}$ & 80 & 5634 \\
\hline $\mathrm{Mg}$ & 1850 & 1990 \\
\hline $\mathrm{Mn}$ & 85 & 63 \\
\hline Mo & $<12.5$ & $<821$ \\
\hline $\mathrm{Na}$ & 9035 & 32400 \\
\hline $\mathrm{Nb}$ & $<65.0$ & NM \\
\hline $\mathrm{Nd}$ & $<35.0$ & NM \\
\hline $\mathrm{Ni}$ & 50 & NM \\
\hline $\mathrm{P}$ & 705 & $<5130$ \\
\hline $\mathrm{Pb}$ & $<85.0$ & $<3500$ \\
\hline $\mathrm{Re}$ & $<10.0$ & NM \\
\hline$S$ & 515 & 1670 \\
\hline $\mathrm{Sb}$ & $\mathrm{NM}$ & $<870$ \\
\hline $\mathrm{Si}$ & 26750 & 12443 \\
\hline $\mathrm{Sn}$ & 30 & $<1400$ \\
\hline $\mathrm{Sr}$ & 60 & 1960 \\
\hline $\mathrm{Ti}$ & 4800 & 1750 \\
\hline $\mathrm{U}$ & NM & 2150 \\
\hline $\mathrm{V}$ & $<20.0$ & $<135$ \\
\hline $\mathrm{Zn}$ & 7930 & 744 \\
\hline $\mathrm{Zr}$ & 3320 & 805 \\
\hline
\end{tabular}


WSRC-TR-2004-00232, REVISION 0 SRNL-RPP-2004-00044, REVISION 0

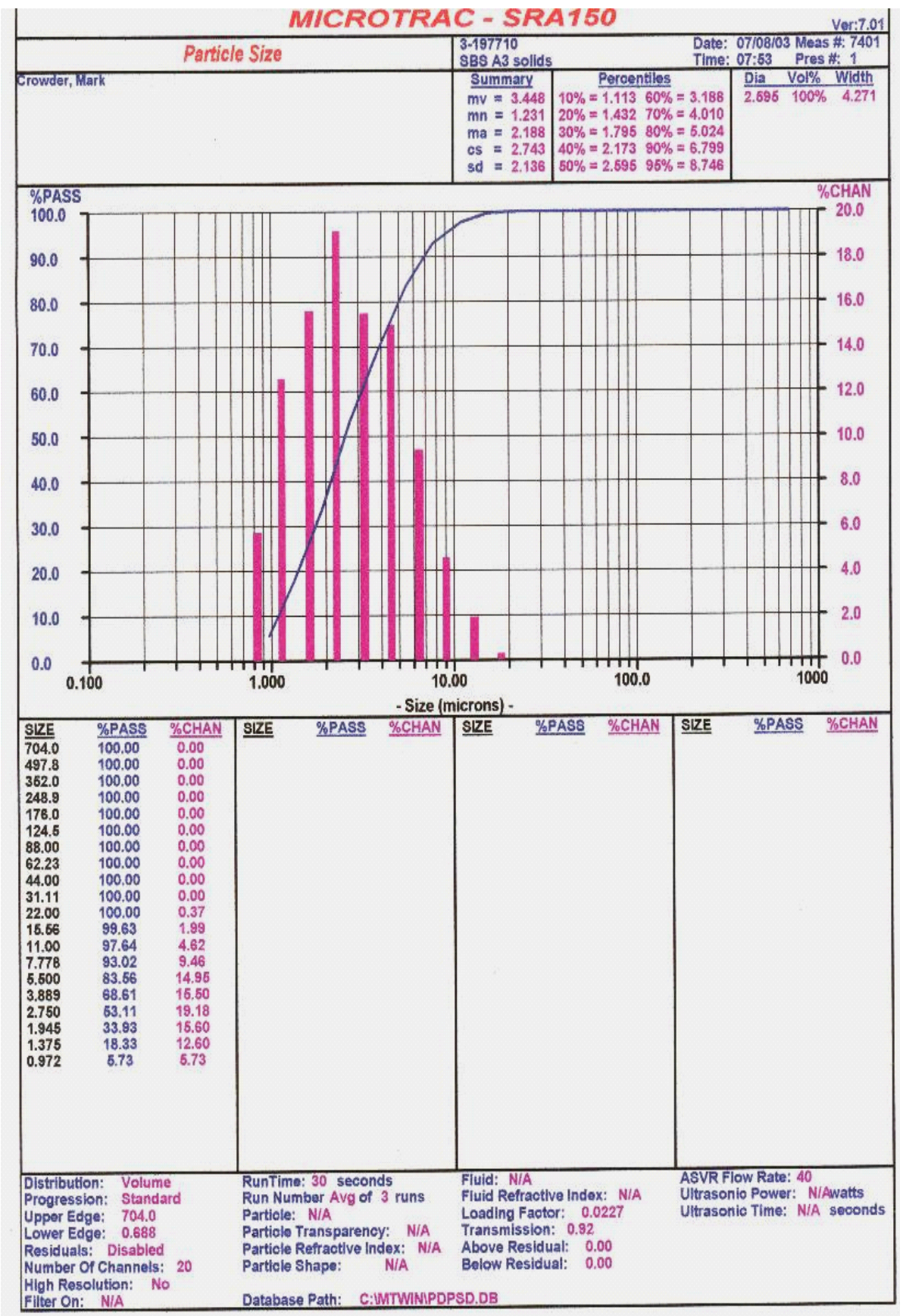

Figure A-1. Particle-Size Distribution for SBS A3 Solids

The "\% PASS" (blue colored) is the percentage of particles smaller or equal to the corresponding particle size. The "\% CHAN" (reddish color) is the percentage of particles between the particle size and the closest smaller particle size in the table. In the example above, $68.61 \%$ of the particles are below 3.889 microns and $15.50 \%$ of the particles are between 2.75 and 3.889 microns. The table labeled Dia, Vol, and Width are the distribution for one or more peaks/modes within the data. In this case, there is only one mode (e.g. one can have bi-modal, tri-modal, etc distribution). "mv" is the mean diameter of the volume distribution. "mn" is the mean diameter of the number distribution. "ma" is the mean diameter of the area distribution. "cs" is the calculated specific surface area $\left(\mathrm{m}^{2} / \mathrm{cc}\right)$ of the sample based on smooth, solid spherical particles. This number can in no way be related to a measured surface area, for example BET by adsorption. "sd" is the standard deviation for the distribution (not the variation about the mean). Specifically, "sd" is difference between the diameters of the $84 \%$ and $16 \%$ particles that have passed divided by 2. "sd" does not provide an indication of the statistical error about the mean of multiple

measurements. The table on the bottom provides the type of graph provided, operating parameters of the particle size analyzer and the number of sample runs. 
Three unreleased model runs (Longwell 2003) were provided for determining blend ratios for actual waste evaporation tests. The runs were:

1. AN-104 tank Run ACM Ver. 2.0; 20 MTG/day ILAW (Nov. 19, 2002)

2. AN-104 tank Run ACM Ver. 2.1; 30 MTG/day ILAW (May 11, 2003)

3. AN-104 tank Run ACM Ver. 2.1 Dilute TLP Setpoint; 30 MTG/day ILAW (May 15, 2003)

\begin{tabular}{|c|c|c|c|c|c|}
\cline { 2 - 6 } \multicolumn{1}{c|}{} & $\begin{array}{c}\text { Na Conc. } \\
\text { Treated LAW Feed }\end{array}$ & $\begin{array}{c}\text { Na Conc. } \\
\text { Recycle }\end{array}$ & $\begin{array}{c}\text { Na Conc. } \\
\text { Evaporator } \\
\text { Product }\end{array}$ & $\begin{array}{c}\text { AN-104 / } \\
\text { Recycle }\end{array}$ & $\begin{array}{c}\text { AN-104 / Recycle } \\
\text { at Feed = 4.67 M Na }\end{array}$ \\
\hline 1. & 4.67 & 0.31 & 8.00 & 0.386 & 0.386 \\
\hline 2. & 6.47 & 0.40 & 8.00 & 0.379 & 0.458 \\
\hline 3. & 6.47 & 0.34 & 6.08 & 0.336 & 0.412 \\
\hline
\end{tabular}

The following message from the Longwell 2003 email from Dave Harty, Pretreatment Operations (RPP-WTP), explains the unreleased model results used to determine experimental blend ratios.

'The ACM Version 2.1 runs did not dilute the feed through the Ultrafiltration Process which would give a lower Na molarity (higher flowrate) for the Treated LAW feed to the TLP Evaporator. Diluting the feed to the TLP evaporator gives the same Na molarity of the ACM Version 2.0 run, and increases the feed flow rate by a factor of 1.385 (6.47/4.67). Also note that the 2.0 run was performed at $20 \mathrm{MTG} /$ day ILAW and the 2.1 runs were performed at $30 \mathrm{MTG} / \mathrm{ILAW}$. Recycle rates do not scale up directly with production rate because of the nature of the fixed-rate SBS purge cycle defined by engineering.'

Though details and setpoints in the process may change, the above model results were used to select test blends of $35 \%$ and $45 \%$ AN-104 pretreated waste with SBS A3 recycle. 
WSRC-TR-2004-00232, REVISION 0

SRNL-RPP-2004-00044, REVISION 0

This page intentionally left blank. 
WSRC-TR-2004-00232, REVISION 0

SRNL-RPP-2004-00044, REVISION 0

APPENDIX B.

CORRECTING 7.29 M NA FEED STOCK

AND BATCHING DILUTED FEED 
WSRC-TR-2004-00232, REVISION 0

SRNL-RPP-2004-00044, REVISION 0

\section{Correcting the 7.29 M Na AN104SBS3565 Pretreated Waste Molarity and Density}

The AN104SBS3565 pretreated waste was further evaporated and duplicate samples were pulled and analyzed, with the average ICP-ES results provided in Table B-1. Based on the ICP-ES analysis for Na, the sodium molarity of the concentrated AN104SBS3565 pretreated waste $7.29 \mathrm{M}$.

Table B-1. ICP-ES Composition of 7.29M Na Concentrated AN104SBS3565 Pretreated Waste

\begin{tabular}{|c|c|c|c|}
\hline \multicolumn{4}{|c|}{$\begin{array}{l}\text { Concentration of elements in } 7.29 \mathrm{M} \mathrm{Na} \\
\text { AN104SBS3565 Pretreated Waste (mg/L) }\end{array}$} \\
\hline $\mathrm{Al}$ & 19300 & $\mathrm{P}$ & 535 \\
\hline $\mathrm{B}$ & 744 & $\mathrm{~Pb}$ & 32.80 \\
\hline $\mathrm{Be}$ & 0.21 & $\mathrm{~S}$ & 2590 \\
\hline $\mathrm{Ca}$ & 49.00 & $\mathrm{Sb}$ & 54.25 \\
\hline $\mathrm{Ce}$ & 25.00 & $\mathrm{Si}$ & 258 \\
\hline $\mathrm{Cr}$ & 211 & $\mathrm{Sn}$ & 45.15 \\
\hline $\mathrm{Fe}$ & 16.90 & $\mathrm{Sr}$ & 11.15 \\
\hline $\mathrm{K}$ & 4600 & $\mathrm{Ti}$ & 7.07 \\
\hline $\mathrm{Li}$ & 32.70 & $\mathrm{U}$ & 75.50 \\
\hline $\mathrm{Mg}$ & 7.43 & $\mathrm{~V}$ & 5.50 \\
\hline Mo & 54.10 & $\mathrm{Zn}$ & 74 \\
\hline $\mathrm{Na}$ & 167500 & $\mathrm{Zr}$ & 3.75 \\
\hline
\end{tabular}

Targeted 5.1, 6.0 and 6.9 M Na pretreated wastes using de-ionized (DI) water were then made from this $7.29 \mathrm{M}$ Na pretreated waste. This batching was performed using volumetric graduated cylinders. The batching ratio of $7.29 \mathrm{M} \mathrm{Na}$ and DI water are provide in Table B-2 and the resulting samples were analyzed for $\mathrm{Na}$ (using AA and ICP-ES), solids analysis using the RPP method, and rheology. The resulting Na molarities are provided in Table B-2. 
WSRC-TR-2004-00232, REVISION 0

SRNL-RPP-2004-00044, REVISION 0

Table B-2. Dilution of 7.29 M Na Feed Stock to Target Molarities

\begin{tabular}{|c|c|c|c|c|}
\hline \multirow{2}{*}{$\begin{array}{c}\text { Target Na } \\
\text { Molarity (M) }\end{array}$} & \multirow{2}{*}{$\begin{array}{c}7.29 \mathrm{M} \mathrm{Na} \\
\text { AN104SBS3565 } \\
\text { Pretreated Waste } \\
\text { (L) }\end{array}$} & \multirow{2}{*}{$\begin{array}{c}\text { DI } \\
\text { water } \\
\text { (L) }\end{array}$} & \multicolumn{2}{|c|}{ Measured Na Molarity (M) } \\
\hline & & & $\mathbf{A A}$ & ICP-ES \\
\hline 5.1 & 0.105 & 0.045 & 4.72 & 4.74 \\
\hline 6.0 & 0.185 & 0.040 & 5.55 & 5.66 \\
\hline 6.9 & 0.142 & 0.008 & 6.15 & 6.48 \\
\hline
\end{tabular}

All targeted Na molarities were below target, by approximately $0.5 \mathrm{M} \mathrm{Na}$. Preliminary density and $\mathrm{wt} \%$ total solids measurements of the diluted 5.1,6.0 and 6.9 M Na pretreated wastes were $1.239,1.273$, and $1.32 \mathrm{~g} / \mathrm{mL}$ and $26.91,31.03$, and $34.63 \mathrm{wt} \%$ TS respectively. The 7.29 M Na pretreated waste had lower reported values. SRNL made a decision to proceed in calculating the starting molarity and density of the $7.29 \mathrm{M} \mathrm{Na}$ pretreated waste. Given the preliminary data of the diluted feeds (average molarity, density, $\mathrm{wt} \%$ solids, and mass of remaining sample); the following was calculated for each diluted feed.

Equation B- $1 \quad n_{i}=\frac{M_{i} \cdot m_{i}}{1000 \rho_{i}}$

Equation B- $2 \quad m_{i, \text { solids }}=m_{i} \cdot w t \%_{T S}$

Equation B-3 $\quad V_{i}=\frac{m_{i}}{\rho}$

Equation B-4 $\frac{1}{\rho_{i}}=\frac{w t \%_{T S}}{100 \cdot \rho_{\text {solids }, i}}+\frac{\left(100-w t \%_{T S}\right)}{100 \cdot \rho_{\mathrm{H}_{2} \mathrm{O}}}$

where: $\mathrm{M}_{\mathrm{i}}=$ molarity of pretreated waste (moles/liter)

$\mathrm{n}_{\mathrm{i}}=$ moles of sodium in pretreated waste (moles)

$\mathrm{m}_{\mathrm{i}}=$ mass of pretreated waste not used $(\mathrm{g})$

$\rho_{\mathrm{i}}=$ density of pretreated waste $(\mathrm{g} / \mathrm{mL})$

$\mathrm{V}_{\mathrm{i}}=$ volume of remaining pretreated waste sample $(\mathrm{mL})$

$\rho_{\text {solids }, \mathrm{i}}=$ density of the solids in the pretreated waste $(\mathrm{g} / \mathrm{mL})$

$\rho_{\mathrm{H}_{2} \mathrm{O}}=$ density of water $=1.0 \mathrm{~g} / \mathrm{mL}$ 
Given the starting volumes of the 7.29 M Na pretreated waste and DI water (from Table B-2) and the volume of dilute pretreated waste remaining (Equation B- 3), the volume of 7.29 M $\mathrm{Na}$ pretreated waste and DI water in this remaining diluted feed were determined by:

Equation B- 5

$$
V_{7.29 M_{-} \text {in_sample }, i}=\frac{V_{7.29 M_{\text {Used }}, i}}{V_{7.29 M_{\text {Used }}, i}+V_{D I_{\text {Used }}, i}} V_{i}
$$

Equation B- 6

$$
V_{D I_{-} i n_{-} \text {sample }, i}=\frac{V_{D I_{\text {Used }}, i}}{V_{7.29 M_{\text {Used }}, i}+V_{D I_{\text {Used }}, i}} V_{i}
$$

where: $V_{7.29 M \_i n \_s a m p l e, j}=$ volume of $7.29 \mathrm{M} \mathrm{Na}$ pretreated waste in diluted stock $(\mathrm{mL})$ $\mathrm{V}_{\text {DI_in_sample,j }}=$ volume of DI water in diluted stock $(\mathrm{mL})$

The total solids and moles of solids must come from the 7.29 $\mathrm{M} \mathrm{Na}$ pretreated waste. The molarity, wt $\%$ TS and density were then determined for the $7.29 \mathrm{M} \mathrm{Na}$ pretreated waste using the following equations, for each of the diluted pretreated wastes. In calculating the mass of the 7.29 M Na pretreated waste in the remaining sample, it is assumed that the density of DI water is $1.0 \mathrm{~g} / \mathrm{mL}$.

Equation B- 7

$$
M_{7.29 M, i}=\frac{n_{i}}{V_{7.29 M \_i n_{-} s a m p l e, i}}
$$

Equation B- 8

$$
m_{7.29 M, i}=m_{i}-V_{D I \_i n_{-} s a m p l e, i} \cdot \rho_{D I, \text { water }}=m_{i}-V_{D I \_i n \_s a m p l e, i}
$$

Equation B- 9

$$
\frac{1}{\rho_{7.29 M, i}}=\frac{w t \%_{T S, i}}{100 \cdot \rho_{\text {solids }, i}}+\frac{\left(100-w t \%_{T S, i}\right)}{100 \cdot \rho_{\mathrm{H}_{2} \mathrm{O}}}
$$

where: $\mathrm{M}_{7.29 \mathrm{M}, \mathrm{i}}=$ Molarity of $7.29 \mathrm{M} \mathrm{Na}$ pretreated waste

$\mathrm{m}_{7.29 \mathrm{M}, \mathrm{i}}=$ mass of $7.29 \mathrm{M} \mathrm{Na}$ pretreated waste $(\mathrm{g})$

$\rho_{7.29 \mathrm{M}, \mathrm{i}}=$ density of $7.29 \mathrm{M} \mathrm{Na}$ pretreated waste $(\mathrm{g} / \mathrm{mL})$

The results from these calculations for each of the diluted feeds are in Table B-3. The "dilute" columns in Table B-3 are for the diluted pretreated waste and the "Feed Stock" is the calculated properties for the 7.29 M Na AN104SBS3565 pretreated waste. 
WSRC-TR-2004-00232, REVISION 0

SRNL-RPP-2004-00044, REVISION 0

Table B-3. Calculated 7.29 M Na AN104SBS3565 Pretreated Waste Properties from Diluted Pretreated Wastes Properties

\begin{tabular}{|c|c|c|c|c|c|c|}
\hline \multirow{2}{*}{ Quantity } & \multicolumn{2}{|c|}{ 5.1 M Na Target } & \multicolumn{2}{|c|}{ 6.0 M Na Target } & \multicolumn{2}{|c|}{$6.9 \mathrm{M}$ Na Target } \\
\hline & Diluted & Feed Stock & Diluted & Feed Stock & Dilute & Feed Stock \\
\hline $\mathrm{Wt} \%$ total solids & $26.9 \%$ & $35.5 \%$ & $31.0 \%$ & $36.07 \%$ & $34.6 \%$ & $36.09 \%$ \\
\hline$\rho_{\mathrm{i}}(\mathrm{g} / \mathrm{mL})$ & 1.239 & 1.341 & 1.273 & 1.332 & 1.320 & 1.338 \\
\hline$\rho_{\text {solids }}(\mathrm{g} / \mathrm{mL})$ & 3.53 & 3.53 & 3.237 & 3.237 & 3.334 & 3.334 \\
\hline $\mathrm{M}_{\mathrm{I}}(\mathrm{moles} / \mathrm{L})$ & 4.73 & 6.76 & 5.60 & 6.814 & 6.32 & 6.671 \\
\hline $\mathrm{n}_{\mathrm{i}}$ (moles) & 0.453 & 0.453 & 1.032 & 1.032 & 0.613 & 0.613 \\
\hline $\mathrm{m}_{\text {total }}(\mathrm{g})$ & 118.68 & $-\ldots$ & 234.48 & $-\ldots$ & 128.17 & $-\ldots$ \\
\hline $\mathrm{m}_{\mathrm{DI}}(\mathrm{g})$ & -- & 28.74 & $-\ldots$ & 32.75 & -- & 5.18 \\
\hline $\mathrm{m}_{7.28 \mathrm{M}}(\mathrm{g})$ & $-\ldots$ & 89.95 & -- & 201.74 & -- & 122.99 \\
\hline $\mathrm{m}_{\text {solids }}(\mathrm{g})$ & 31.94 & 31.94 & 72.76 & 72.76 & 44.38 & 44.38 \\
\hline $\mathrm{V}_{\mathrm{i}}(\mathrm{mL})$ & 95.79 & $-\ldots$ & 184.20 & $-\ldots$ & 97.09 & $-\ldots$ \\
\hline $\mathrm{V}_{7.28 \mathrm{M}}(\mathrm{mL})$ & $-\ldots$ & 67.05 & $-\ldots$ & 151.45 & $-\ldots$ & 91.92 \\
\hline
\end{tabular}

The elemental concentration in the $7.29 \mathrm{M}$ Na pretreated waste were then corrected by multiplying the average sodium molarity in Table B-3 (6.75 M Na) and dividing it by the measured molarity of 7.29 M Na. The results of the final $6.75 \mathrm{M} \mathrm{Na}$ are shown in Table B-4 and will be used as a basis for determining the elemental composition of the other concentrated wastes.

Table B-4. Composition of corrected 6.75 M Na Concentrated AN104SBS3565 Pretreated Waste

\begin{tabular}{|c|c|c|c|}
\hline \multicolumn{5}{|c|}{ Concentration of elements in 6.75 M Na AN104SBS3565 } \\
Pretreated Waste (mg/L) \\
\hline $\mathrm{Al}$ & 17870.4 & $\mathrm{P}$ & 495.4 \\
\hline $\mathrm{B}$ & 688.9 & $\mathrm{~Pb}$ & 30.4 \\
\hline $\mathrm{Be}$ & 0.2 & $\mathrm{~S}$ & 2398.1 \\
\hline $\mathrm{Ca}$ & 45.4 & $\mathrm{Sb}$ & 50.2 \\
\hline $\mathrm{Ce}$ & 23.1 & $\mathrm{Si}$ & 238.9 \\
\hline $\mathrm{Cr}$ & 195.4 & $\mathrm{Sn}$ & 41.8 \\
\hline $\mathrm{Fe}$ & 15.6 & $\mathrm{Sr}$ & 10.3 \\
\hline $\mathrm{K}$ & 4259.3 & $\mathrm{Ti}$ & 6.5 \\
\hline $\mathrm{Li}$ & 30.3 & $\mathrm{U}$ & 69.9 \\
\hline $\mathrm{Mg}$ & 6.9 & $\mathrm{~V}$ & 5.1 \\
\hline $\mathrm{Mo}$ & 50.1 & $\mathrm{Zn}$ & 68.5 \\
\hline $\mathrm{Na}$ & 155092.6 & $\mathrm{Zr}$ & 3.5 \\
\hline \multicolumn{4}{|c}{} \\
\end{tabular}




\section{Correcting Diluted AN104SBS3565 Pretreated Waste to Targeted Molarities}

Since all the targeted pretreated wastes were low in sodium molarity, the molarities were corrected by either adding additional $6.75 \mathrm{M} \mathrm{Na}$ pretreated waste (using average Na molarity and density from Table B-3 of $6.75 \mathrm{M} \mathrm{Na}$ and $1.337 \mathrm{~g} / \mathrm{mL}$ respectively) and/or via evaporation.

If additional 6.75 M Na pretreated waste was added to the diluted pretreated wastes, then the following was performed using an excel spreadsheet;

1. Make initial guess of mass of $6.75 \mathrm{M} \mathrm{Na}$ pretreated waste to add, $\mathrm{m}_{6.75 \mathrm{Madd}}$

2. Calculate volume of $6.75 \mathrm{M}$ Na pretreated waste added using average density, $\mathrm{V}_{6.75 \mathrm{Madd}}$

3. Calculate $\mathrm{Na}$ moles from $6.75 \mathrm{M}$ Na pretreated waste added, $\mathrm{n}_{6.75 \mathrm{Madd}}$

4. Calculate total mass, $\mathrm{m}_{\text {total }}=\mathrm{m}_{6.75 \mathrm{Madd}}+\mathrm{m}_{\mathrm{i}}$

5. Calculate total volume, $\mathrm{V}_{\text {total }}=\mathrm{V}_{6.75 \text { Madd }}+\mathrm{V}_{\mathrm{i}}$

6. Calculate total Na moles, $\mathrm{n}_{\text {total }}=\mathrm{n}_{6.75 \mathrm{Madd}}+\mathrm{n}_{\mathrm{i}}$

7. Calculate Na molarity of batch, $\mathrm{M}_{\text {total }}=\mathrm{n}_{\text {total }} / \mathrm{V}_{\text {total }}$

The above procedure was applied to both the 5.1 and $6.0 \mathrm{M} \mathrm{Na}$ pretreated wastes by using the go seek function in Excel to target the molarity of the batch by adjusting the mass of 6.75 $\mathrm{M} \mathrm{Na}$ pretreated waste to add. The results are in Table B-5.

Because the molarity of the $6.75 \mathrm{M} \mathrm{Na}$ pretreated waste was below the targeted $6.9 \mathrm{M} \mathrm{Na}$ pretreated waste, an additional $30 \mathrm{~mL}$ of the $6.75 \mathrm{M} \mathrm{Na}$ pretreated waste was added and this batch was allowed to evaporate to the targeted $6.9 \mathrm{M} \mathrm{Na}$. The total moles of sodium, volume, and mass were first determined. The mass of water to evaporate was then determined by targeting the molarity of $6.9 \mathrm{M} \mathrm{Na}$. Calculated results are shown in Table B-5 and will be used to determine compositional makeup of the pretreated waste and melter feed.

Table B-5. Correcting Targeted Pretreated Waste Molarities for Melter Feed

\begin{tabular}{|c|c|c|c|c|}
\hline \multirow{2}{*}{ Quantity } & \multirow{2}{*}{ units } & \multicolumn{3}{|c|}{ Pretreated Waste Molarities } \\
\cline { 3 - 5 } & & $\mathbf{5 . 1 M}$ Na & $\mathbf{6 . 0}$ M Na & $\mathbf{6 . 9 M}$ Na \\
\hline Starting Volume & $\mathrm{mL}$ & 95.79 & 166.86 & 128.17 \\
\hline Starting Mass & $\mathrm{g}$ & 118.684 & 212.416 & 97.09 \\
\hline Starting Density & $\mathrm{g} / \mathrm{mL}$ & 1.239 & 1.273 & 1.320 \\
\hline Moles of Na & $\mathrm{moles}$ & 0.452 & 0.934 & 0.613 \\
\hline Mass of 6.75M Na added & $\mathrm{g}$ & 29.532 & 131.689 & 33.43 \\
\hline Volume of 6.75M Na added & $\mathrm{mL}$ & 22.09 & 98.48 & 30.00 \\
\hline Moles of Na added from 6.75M Na & $\mathrm{moles}$ & 0.149 & 0.665 & 0.202 \\
\hline Water evaporated & $\mathrm{g}$ & $\mathrm{N} / \mathrm{A}$ & $\mathrm{N} / \mathrm{A}$ & 8.78 \\
\hline Total moles Na & $\mathrm{moles}$ & 0.601 & 1.599 & 0.815 \\
\hline Final Mass & $\mathrm{g}$ & 148.216 & 344.105 & 159.495 \\
\hline Final Volume & $\mathrm{mL}$ & 117.88 & 265.35 & 118.18 \\
\hline Calculated Final Density & $\mathrm{g} / \mathrm{mL}$ & 1.257 & 1.297 & 1.350 \\
\hline Final calculated Na molarity & $\mathrm{M}$ & 5.1 & 6.02 & 6.9 \\
\hline
\end{tabular}


WSRC-TR-2004-00232, REVISION 0

SRNL-RPP-2004-00044, REVISION 0

The total volume/mass of the 5.1 and $6.9 \mathrm{M} \mathrm{Na}$ pretreated wastes were consumed for melter feed. Table B-6 shows the volumes of $6.75 \mathrm{M}$ Na pretreated waste used for melter feed for the targeted pretreated wastes and the volumes of pretreated waste used for melter feed.

Table B-6. Final Volumes of 6.75 M Na AN104SBS3564 Pretreated Waste Used and the Volume of AN104SBS3565 Pretreated Waste Used for Melter Feed

\begin{tabular}{|c|c|c|c|}
\cline { 2 - 4 } \multicolumn{1}{c|}{} & \multicolumn{3}{|c|}{ Pretreated Waste Molarities } \\
\cline { 2 - 4 } \multicolumn{1}{c|}{} & $\mathbf{5 . 1} \mathbf{M ~ N a}$ & $\mathbf{6 . 0} \mathbf{~ M ~ N a}$ & $\mathbf{6 . 9}$ M Na \\
\hline Volume of $6.75 \mathrm{M} \mathrm{Na}$ Used $(\mathrm{mL})$ & 89.14 & 235.68 & 121.92 \\
\hline Volume of Pretreated Waste $(\mathrm{mL})$ & 117.88 & 265.35 & 118.18 \\
\hline
\end{tabular}


WSRC-TR-2004-00232, REVISION 0

SRNL-RPP-2004-00044, REVISION 0

APPENDIX C.

COMPOSITION OF GLASS FORMER CHEMICALS, MOISTURE CONTENT, AND BATCH CONTENTS 
WSRC-TR-2004-00232, REVISION 0 SRNL-RPP-2004-00044, REVISION 0

Table C-1. Mass Fraction of Compounds in Raw GFC Feed Stock

\begin{tabular}{|c|c|c|c|c|c|c|c|c|c|c|c|c|c|c|c|c|c|c|}
\hline Material & $\mathrm{SiO}_{2}$ & $\mathrm{Al}_{2} \mathrm{O}_{3}$ & $\mathrm{Fe}_{2} \mathrm{O}_{3}$ & $\mathbf{B}_{2} \mathbf{O}_{3}$ & $\mathrm{Cr}_{2} \mathrm{O}_{3}$ & $\mathrm{CaO}$ & MgO & $\mathrm{ZnO}$ & $\mathrm{NiO}$ & $\mathbf{L i}_{2} \mathbf{O}$ & $\mathrm{Na}_{2} \mathrm{O}$ & $\mathrm{K}_{2} \mathrm{O}$ & $\mathrm{TiO}_{2}$ & $\mathrm{ZrO}_{2}$ & $\mathrm{~V}_{2} \mathrm{O}_{5}$ & MnO & $\mathrm{SO}_{4}$ & $\mathbf{U}_{3} \mathbf{O}_{8}{ }^{*}$ \\
\hline Kyanite - Raw -325 & 0.405 & 0.57 & 0.0071 & --- & --- & --- & --- & --- & --- & --- & --- & --- & 0.0105 & --- & --- & --- & --- & --- \\
\hline H3BO3 - Tech. Gran & --- & $-{ }_{-1}$ & --- & 0.5653 & $-{ }_{-1-}$ & --- & --- & --- & --- & --- & $\begin{array}{c}-- \\
\end{array}$ & --- & --- & --- & --- & $\begin{array}{c}-- \\
\end{array}$ & --- & --- \\
\hline Wollastonite - NYAD325 & 0.51 & 0.002 & 0.004 & --- & --- & 0.475 & 0.001 & --- & --- & --- & --- & --- & 0.0002 & --- & --- & 0.001 & --- & --- \\
\hline $\mathrm{Fe}_{2} \mathrm{O}_{3}-5001$ & 0.0135 & 0.0150 & 0.9680 & --- & --- & 0.0004 & 0.0010 & --- & --- & --- & --- & --- & --- & --- & --- & 0.0012 & 0.0010 & --- \\
\hline $\mathrm{Li}_{2} \mathrm{CO}_{3}$ - Tech. Gran & --- & --- & 0.0004 & --- & --- & --- & --- & --- & --- & 0.402 & --- & --- & --- & --- & --- & --- & 0.00004 & --- \\
\hline Olivine - \#180 & 0.4252 & 0.0019 & 0.0768 & $-{ }_{-1}$ & 0.0013 & 0.0002 & 0.4801 & --- & 0.0037 & --- & 0.0002 & 0.0001 & --- & --- & --- & --- & $-{ }_{-1}$ & --- \\
\hline SilCoSil -75 & 0.997 & 0.00135 & 0.00016 & --- & --- & 0.00008 & 0.00008 & --- & --- & --- & 0.00002 & 0.00017 & 0.00008 & --- & --- & --- & --- & --- \\
\hline Rutile 94 - Air floated & 0.022 & 0.005 & 0.007 & --- & 0.0016 & --- & --- & --- & --- & --- & --- & --- & 0.932 & 0.019 & 0.0045 & --- & 0.0003 & --- \\
\hline $\mathrm{ZnO}$ - Kadox 920 & --- & --- & 0.00001 & --- & --- & --- & --- & 0.998 & --- & --- & --- & --- & --- & --- & --- & --- & --- & --- \\
\hline Zircon Flour - Am Min. & 0.3225 & 0.0025 & 0.00075 & --- & --- & --- & --- & --- & --- & --- & --- & --- & 0.00105 & 0.66 & --- & --- & --- & 0.00047 \\
\hline
\end{tabular}

Table C-2. Moisture Content and 1200 Gram Batch of LAWA137

\begin{tabular}{|c|c|c|c|}
\hline \multicolumn{4}{|c|}{ AN104 SRTC 2004 LAWA137 } \\
\hline \multirow{2}{*}{ Glass Former } & Batch Weight & Moisture & Batch Weight - Moisture \\
\cline { 2 - 4 } & (grams) & $\mathbf{g}_{(\text {H2O) }} / \mathbf{g}_{\text {total }}$ & (grams) \\
\hline Kyanite - Raw -325 & 58.20 & 0.0042 & 57.96 \\
\hline H3BO3 - Tech. Gran & 222.34 & N/A & 222.34 \\
\hline Wollastonite - NYAD325 & 135.30 & 0.0036 & 134.81 \\
\hline Fe2O3 - 5001 & 64.94 & 0.0066 & 64.51 \\
\hline Li2CO3 - Tech. Gran & 78.25 & 0.0028 & 78.03 \\
\hline Olivine - \#180 & 37.19 & 0.0044 & 37.03 \\
\hline SilCoSil -75 & 454.89 & 0.0030 & 453.53 \\
\hline Rutile 94 - Air floated & 15.02 & 0.0040 & 14.96 \\
\hline ZnO - Kadox 920 & 38.72 & 0.0042 & 38.56 \\
\hline Zircon Flour - Am Min. & 57.22 & 0.0028 & 57.06 \\
\hline Sugar - & 36.13 & N/A & 36.13 \\
\hline Totals: & $1,198.20$ & N/A & $1,194.91$ \\
\hline
\end{tabular}


WSRC-TR-2004-00232, REVISION 0

SRNL-RPP-2004-00044, REVISION 0

Table C-3. Vendor and ICP-ES Elemental Composition of Batched GFCs

\begin{tabular}{|c|c|c|c|}
\hline \multirow{2}{*}{ Element } & \multirow{2}{*}{ Vendor } & \multicolumn{2}{|c|}{ ICP-ES } \\
\cline { 3 - 4 } & & Average & \% standard deviation \\
\hline $\mathrm{Al}$ & 1.554 & 1.317 & $11.1 \%$ \\
\hline $\mathrm{B}$ & 3.259 & 3.170 & $8.6 \%$ \\
\hline $\mathrm{Ca}$ & 3.824 & 3.407 & $22.2 \%$ \\
\hline $\mathrm{Co}$ & - & 0.056 & $33.4 \%$ \\
\hline $\mathrm{Cr}$ & 0.004 & 0.032 & $37.3 \%$ \\
\hline $\mathrm{Fe}$ & 3.880 & 3.813 & $9.8 \%$ \\
\hline $\mathrm{K}$ & 0.006 & - & - \\
\hline $\mathrm{Li}$ & 1.216 & 1.114 & $10.6 \%$ \\
\hline $\mathrm{Mg}$ & 0.907 & 0.866 & $14.1 \%$ \\
\hline $\mathrm{Mn}$ & 0.014 & 0.010 & $5.6 \%$ \\
\hline $\mathrm{Na}$ & 0.001 & - & - \\
\hline $\mathrm{Ni}$ & 0.009 & - & - \\
\hline $\mathrm{Pb}$ & - & 0.387 & $40.4 \%$ \\
\hline $\mathrm{S}$ & 0.003 & 0.167 & $30.2 \%$ \\
\hline $\mathrm{Si}$ & 22.629 & 22.533 & $12.1 \%$ \\
\hline $\mathrm{Sr}$ & - & 0.005 & $15.2 \%$ \\
\hline $\mathrm{Ti}$ & 0.734 & 0.716 & $10.0 \%$ \\
\hline $\mathrm{U}$ & 0.002 & - & - \\
\hline $\mathrm{V}$ & 0.003 & - & - \\
\hline $\mathrm{Zn}$ & 2.580 & 2.490 & $13.2 \%$ \\
\hline $\mathrm{Zr}$ & 2.351 & 2.117 & $11.3 \%$ \\
\hline $\mathrm{Total}$ & 42.976 & 42.199 & - \\
\hline & & & \\
\hline
\end{tabular}


WSRC-TR-2004-00232, REVISION 0

SRNL-RPP-2004-00044, REVISION 0

\section{APPENDIX D. FLOW CURVES}


WSRC-TR-2004-00232, REVISION 0

SRNL-RPP-2004-00044, REVISION 0

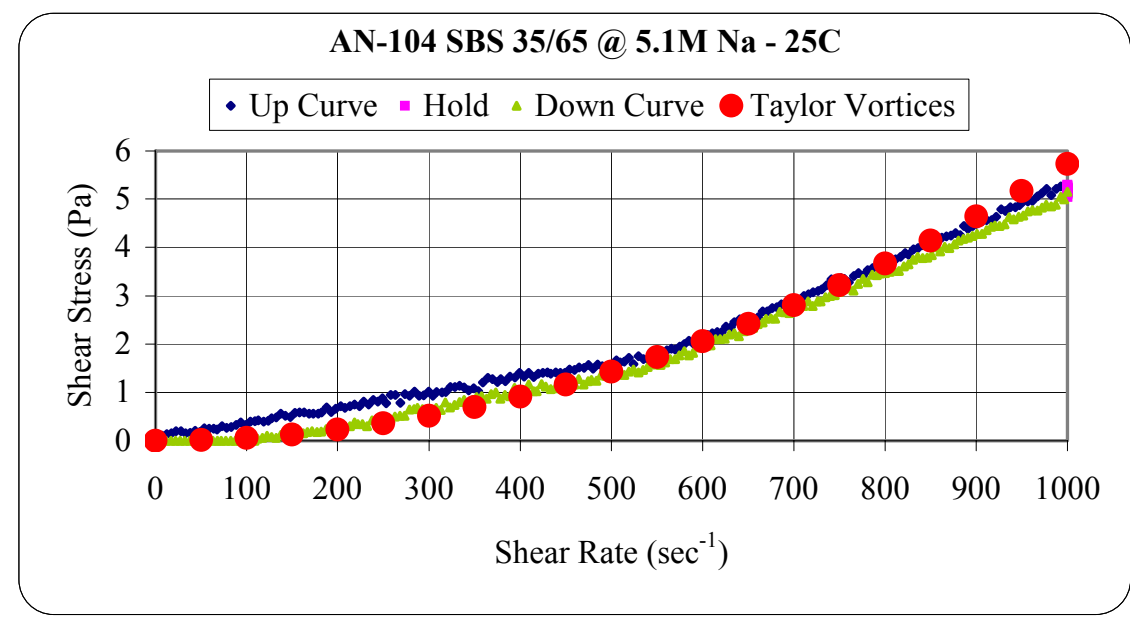

Figure D-1. 5.1 M Na AN104SBS3565 Pretreated Waste Flow Curve \#1 at $25^{\circ} \mathrm{C}$

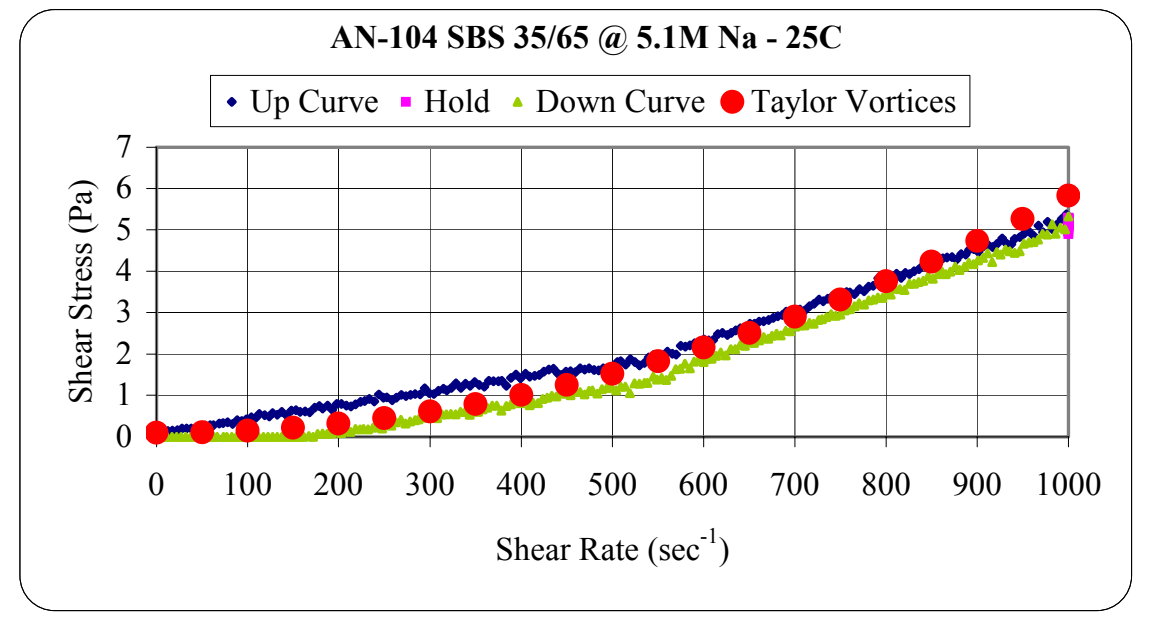

Figure D-2. $5.1 \mathrm{M}$ Na AN104SBS3565 Pretreated Waste Flow Curve \#2 at $25^{\circ} \mathrm{C}$

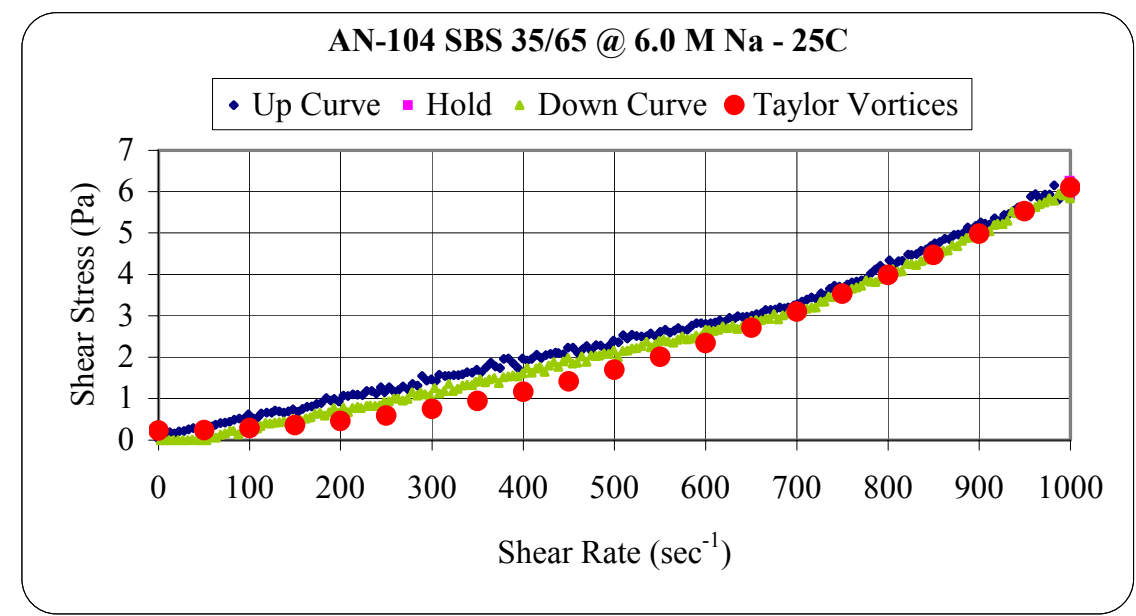

Figure D-3. $\quad 6.0$ M Na AN104SBS3565 Pretreated Waste Flow Curve \#1 at $25^{\circ} \mathrm{C}$ 
WSRC-TR-2004-00232, REVISION 0

SRNL-RPP-2004-00044, REVISION 0

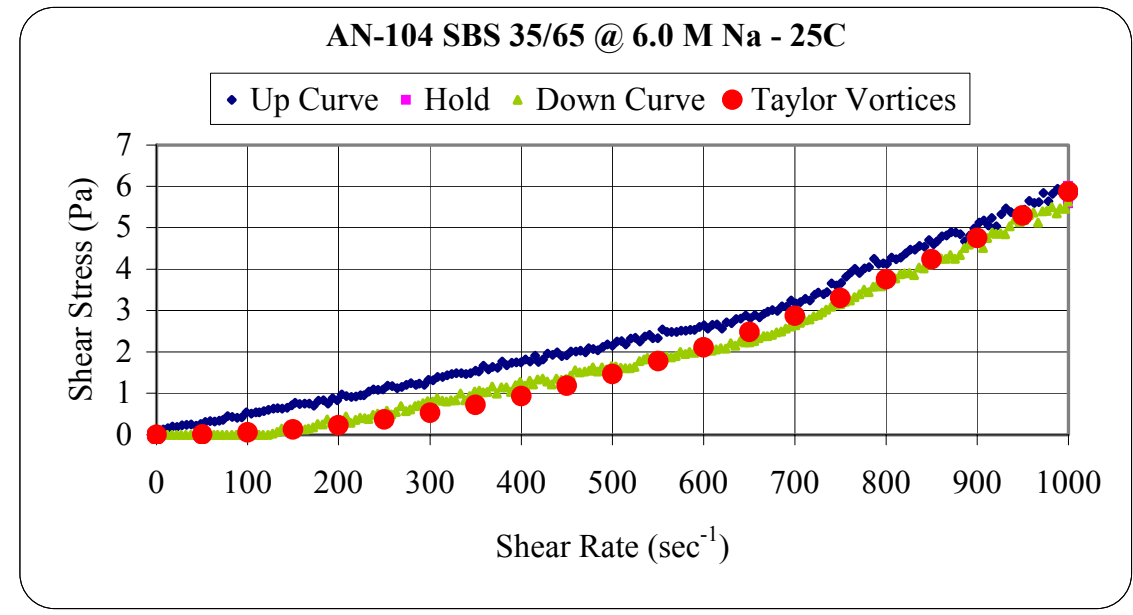

Figure D-4. 6.0 M Na AN104SBS3565 Pretreated Waste Flow Curve \#2 at $25^{\circ} \mathrm{C}$

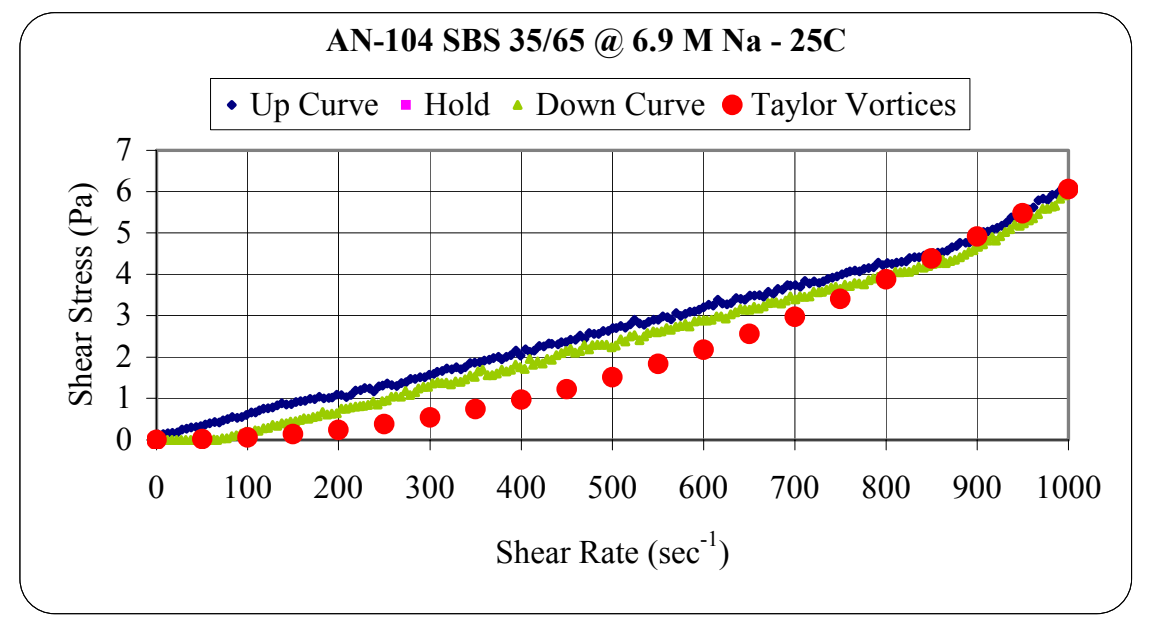

Figure D-5. 6.9 M Na AN104SBS3565 Pretreated Waste Flow Curve \#1 at $25^{\circ} \mathrm{C}$

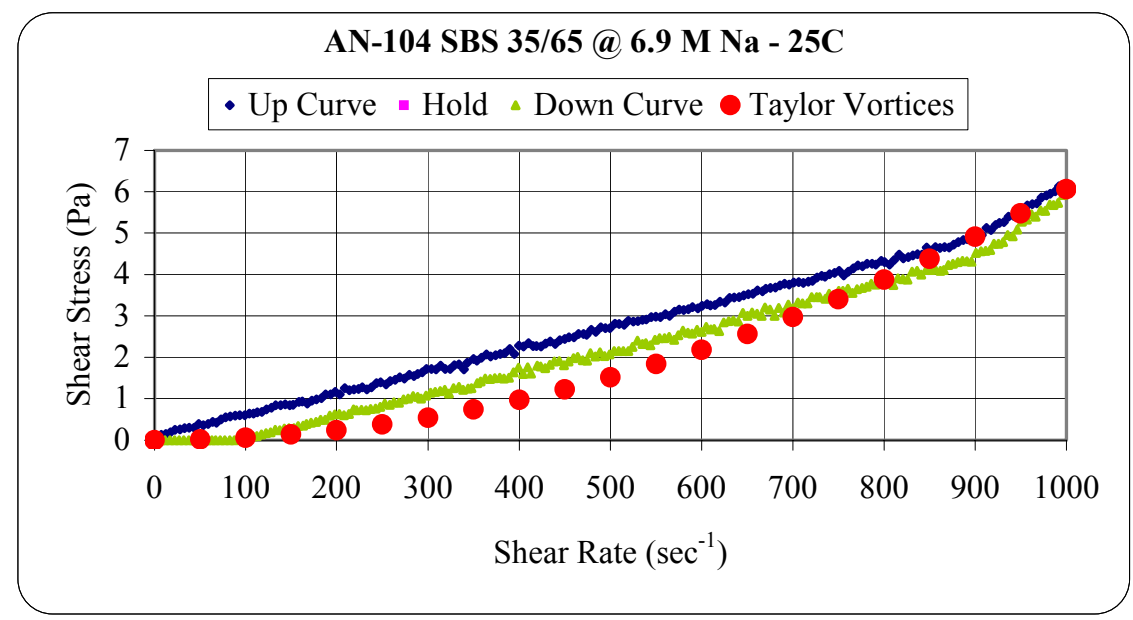

Figure D-6. 6.9 M NaAN104SBS3565 Pretreated Waste Flow Curve \#2 at $25^{\circ} \mathrm{C}$ 
WSRC-TR-2004-00232, REVISION 0

SRNL-RPP-2004-00044, REVISION 0

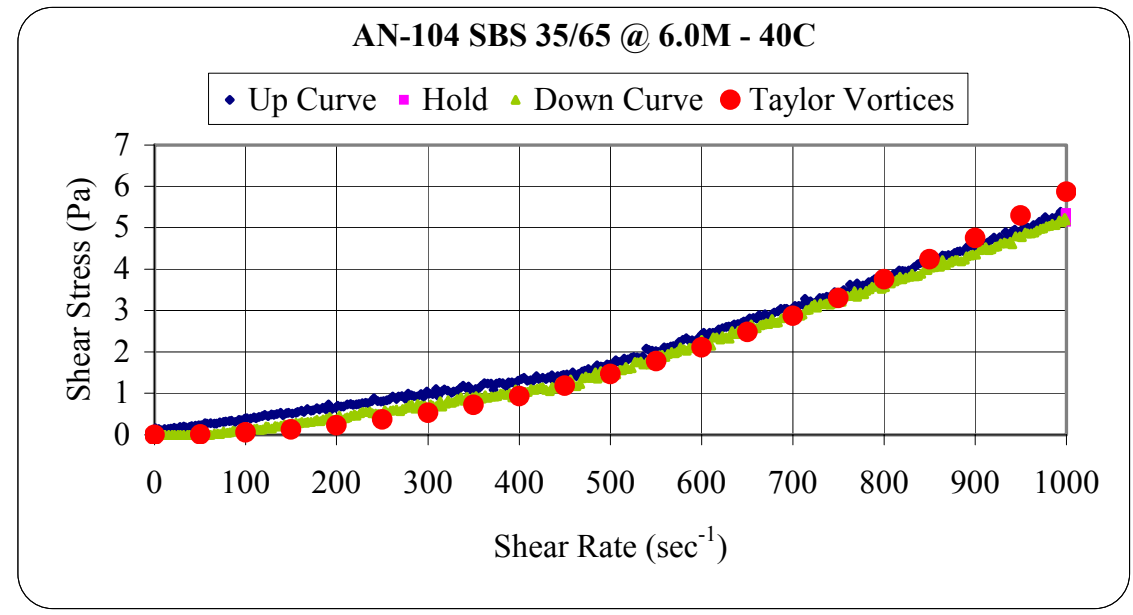

Figure D-7. 6.0 M Na AN104SBS3565 Pretreated Waste Flow Curve \#1 at $40^{\circ} \mathrm{C}$

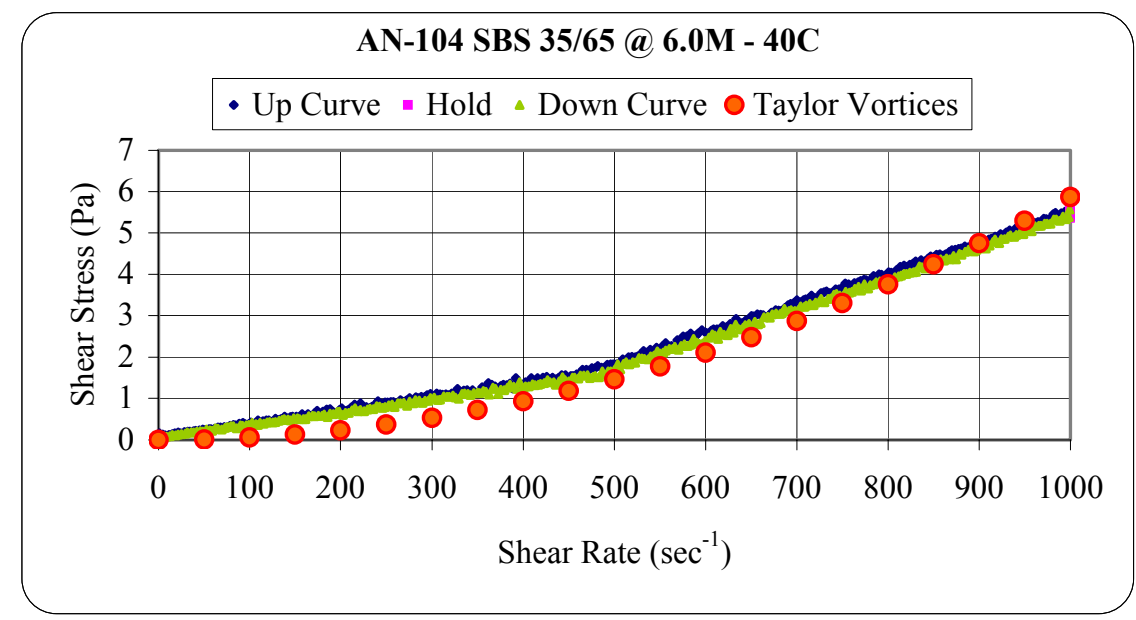

Figure D-8. 6.0 M Na AN104SBS3565 Pretreated Waste Flow Curve \#2 at $40^{\circ} \mathrm{C}$

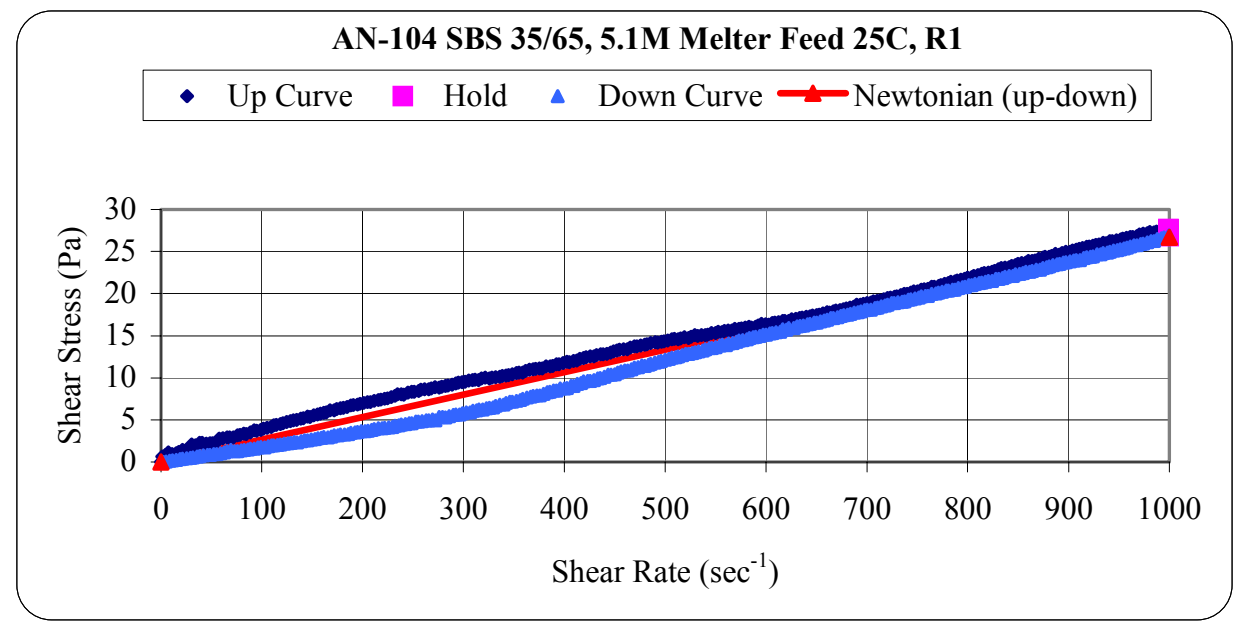

Figure D-9. 5.1 M Na AN104SBS3565 Melter Feed Flow Curve \#1 at $25^{\circ} \mathrm{C}$ 
WSRC-TR-2004-00232, REVISION 0

SRNL-RPP-2004-00044, REVISION 0

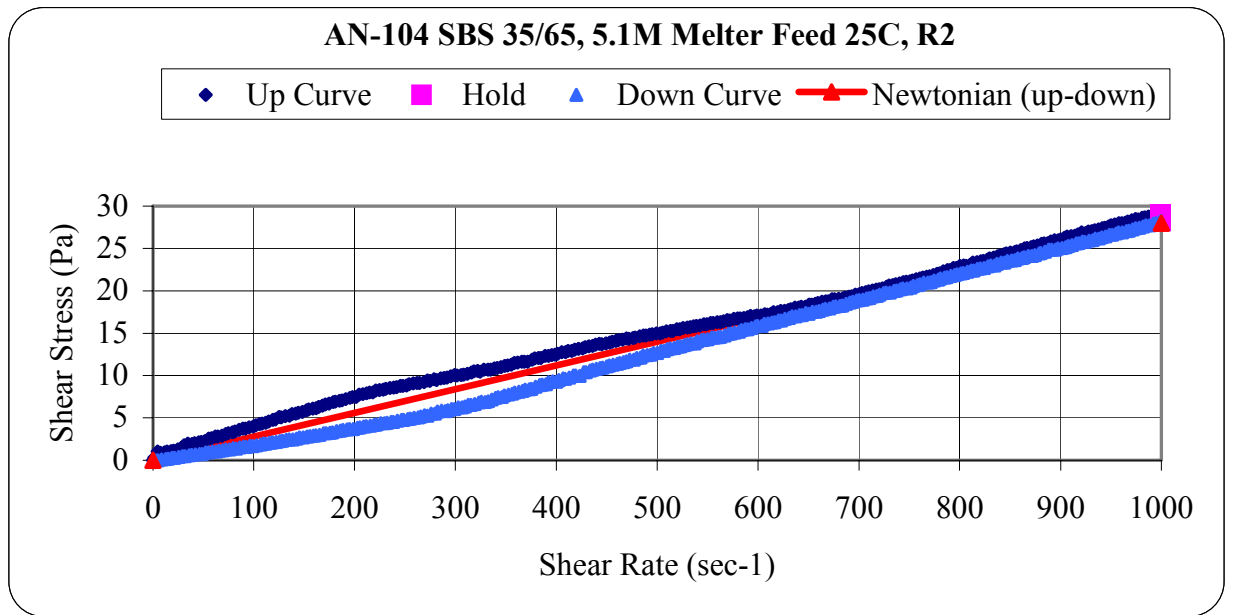

Figure D-10. 5.1 M Na AN104SBS3565 Melter Feed Flow Curve \#2 at $25^{\circ} \mathrm{C}$

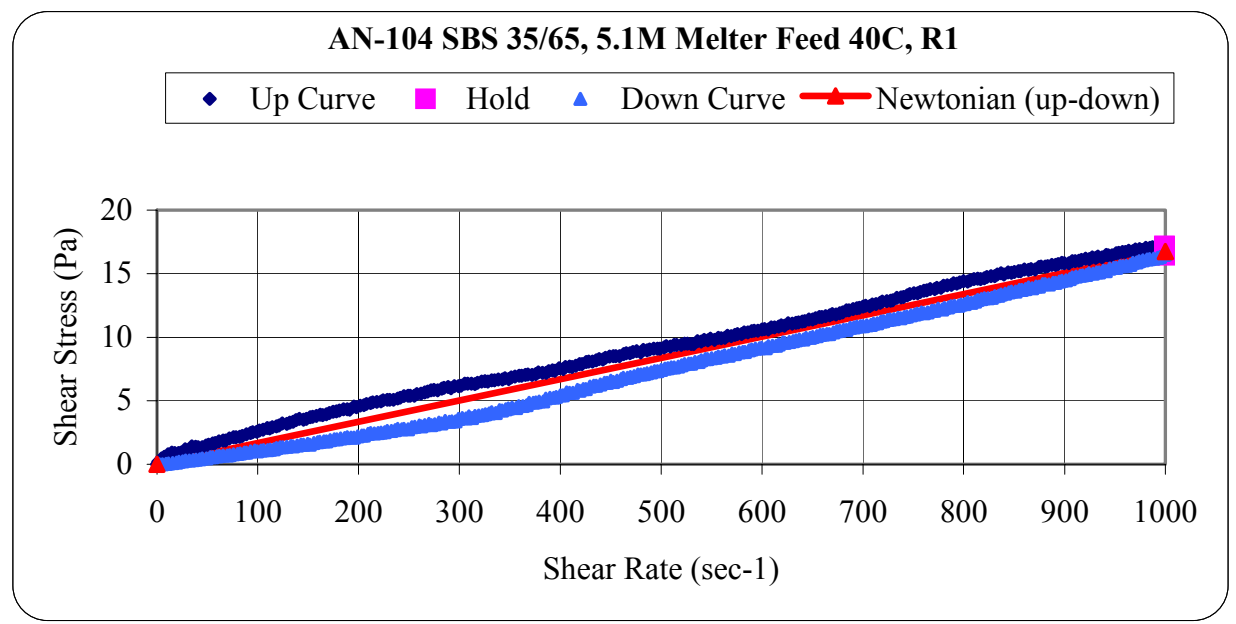

Figure D-11. 5.1 M Na AN104SBS3565 Melter Feed Flow Curve \#1 at $40^{\circ} \mathrm{C}$

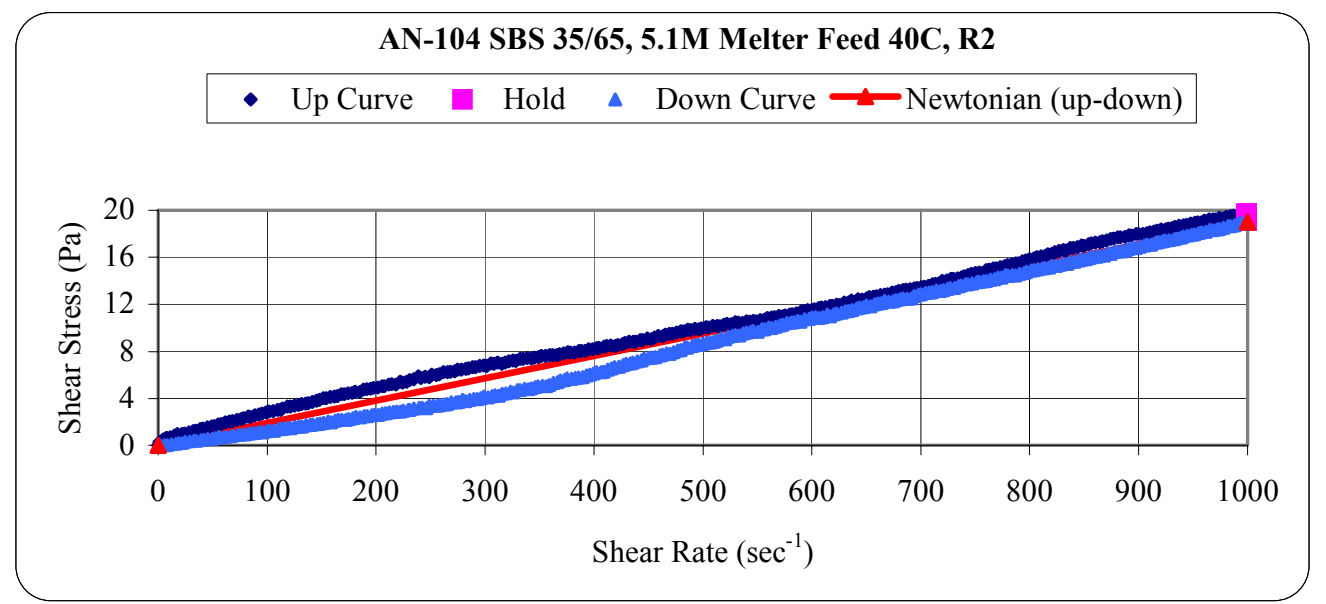

Figure D-12. 5.1 M Na AN104SBS3565 Melter Feed Flow Curve \#2 at $40^{\circ} \mathrm{C}$ 
WSRC-TR-2004-00232, REVISION 0

SRNL-RPP-2004-00044, REVISION 0

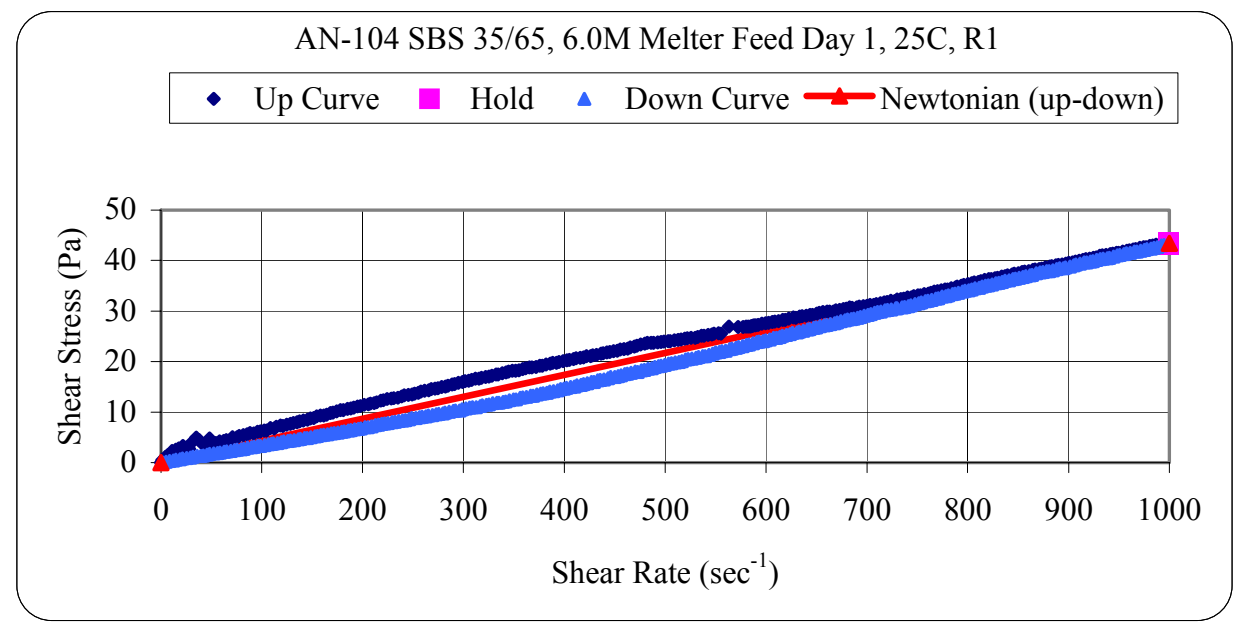

Figure D-13. 6.0 M Na AN104SBS3565 Melter Feed Flow Curve \#1, Day 1 at $25^{\circ} \mathrm{C}$

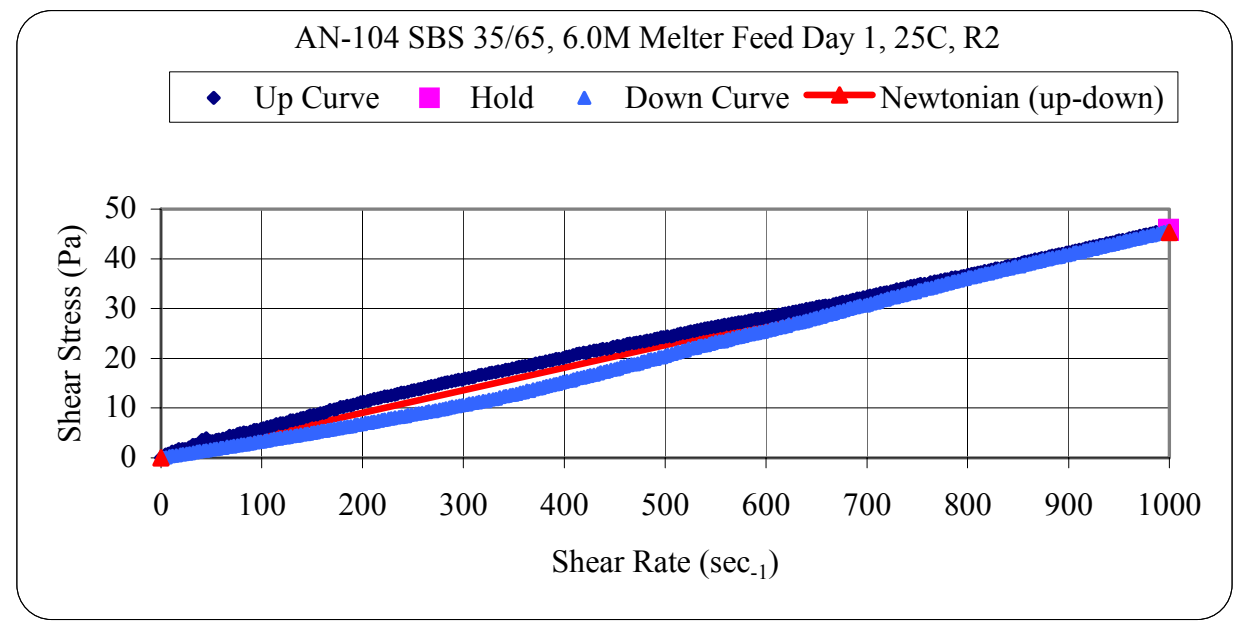

Figure D-14. 6.0 M Na AN104SBS3565 Melter Feed Flow Curve \#2, Day 1 at $25^{\circ} \mathrm{C}$

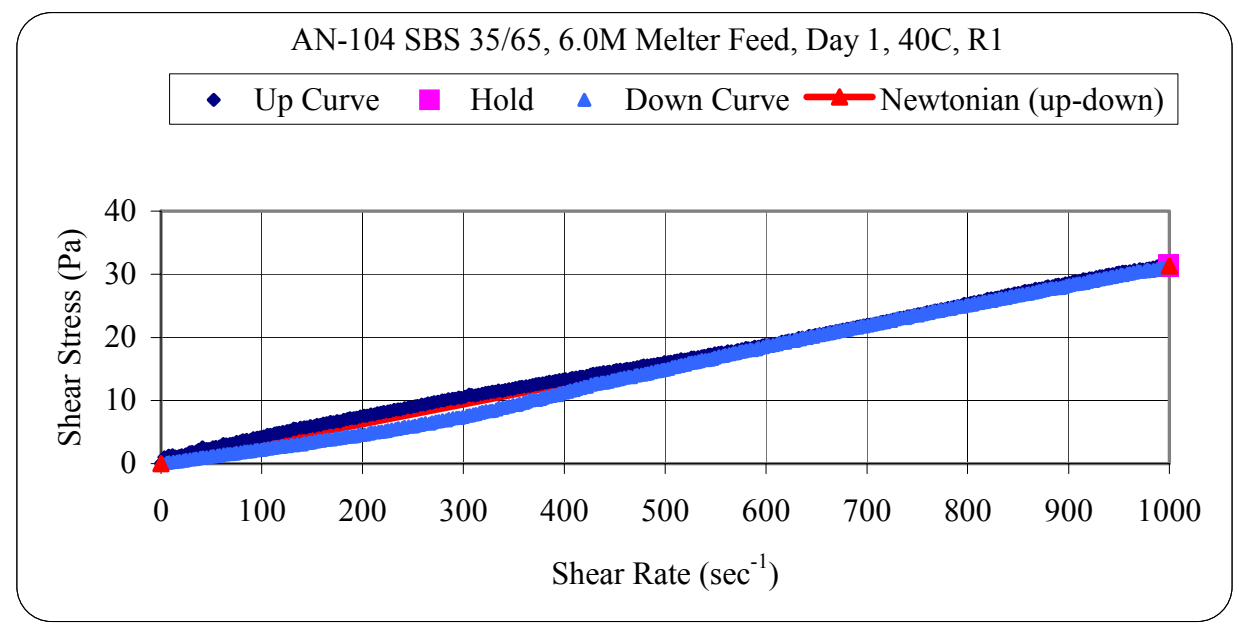

Figure D-15. 6.0 M Na AN104SBS3565 Melter Feed Flow Curve \#1, Day 1 at $40^{\circ} \mathrm{C}$ 
WSRC-TR-2004-00232, REVISION 0

SRNL-RPP-2004-00044, REVISION 0

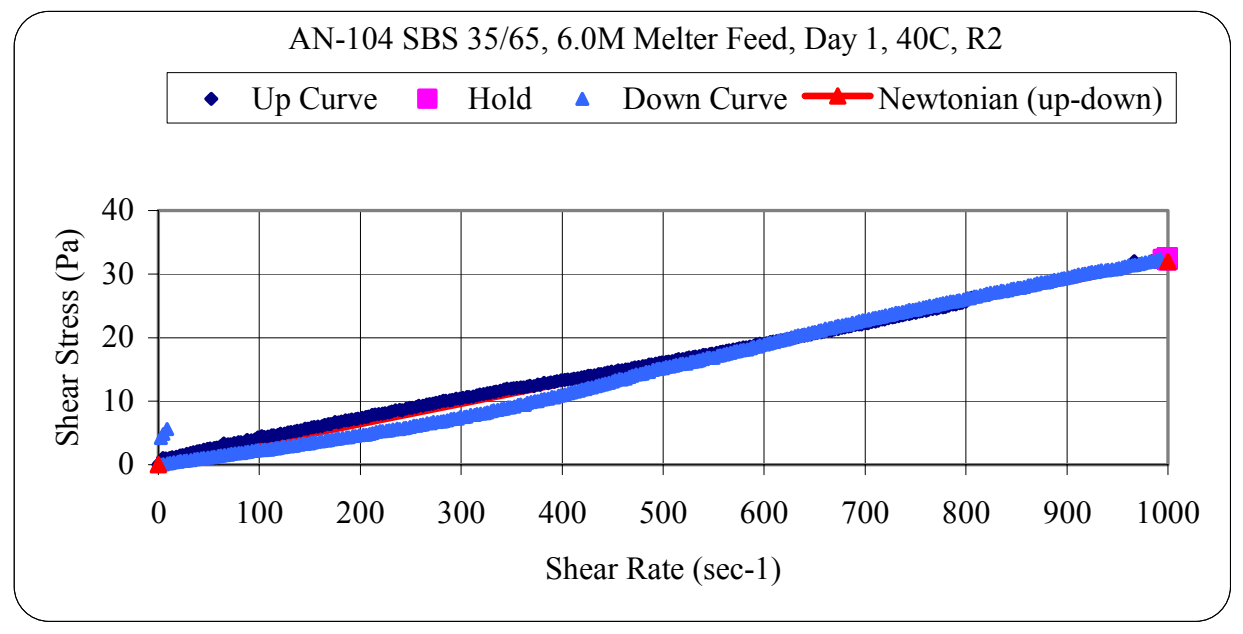

Figure D-16. 6.0 M Na AN104SBS3565 Melter Feed Flow Curve \#2, Day 1 at $40^{\circ} \mathrm{C}$

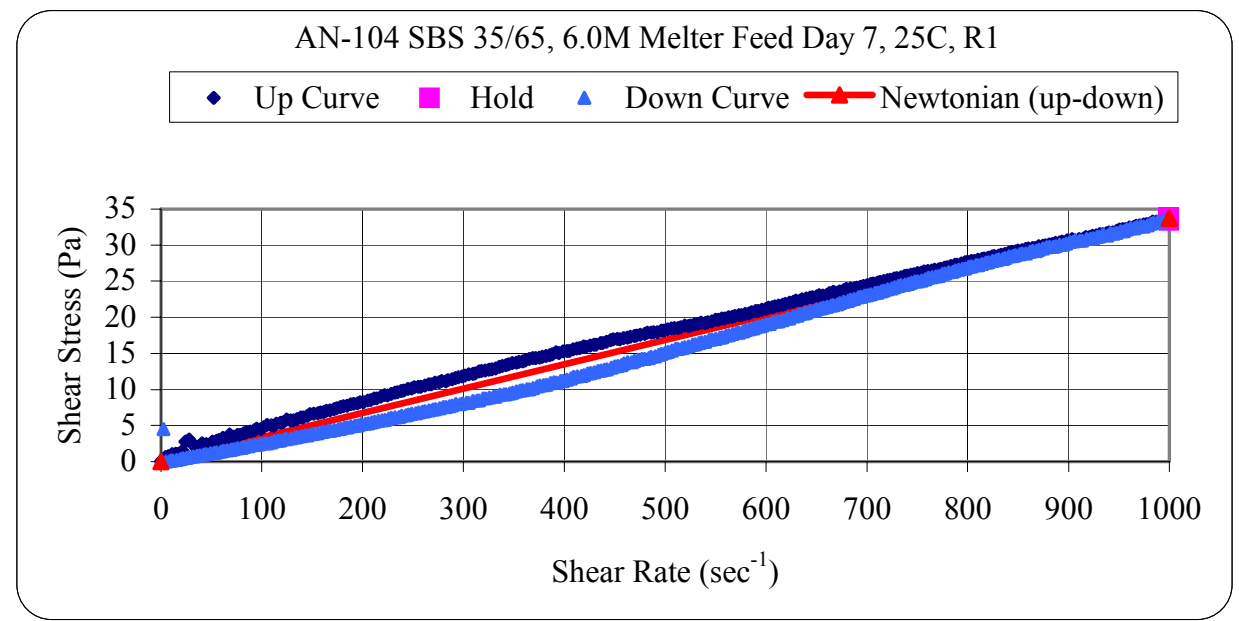

Figure D-17. $6.0 \mathrm{M}$ NaAN104SBS3565 Melter Feed Flow Curve \#1, Day 7 at $25^{\circ} \mathrm{C}$

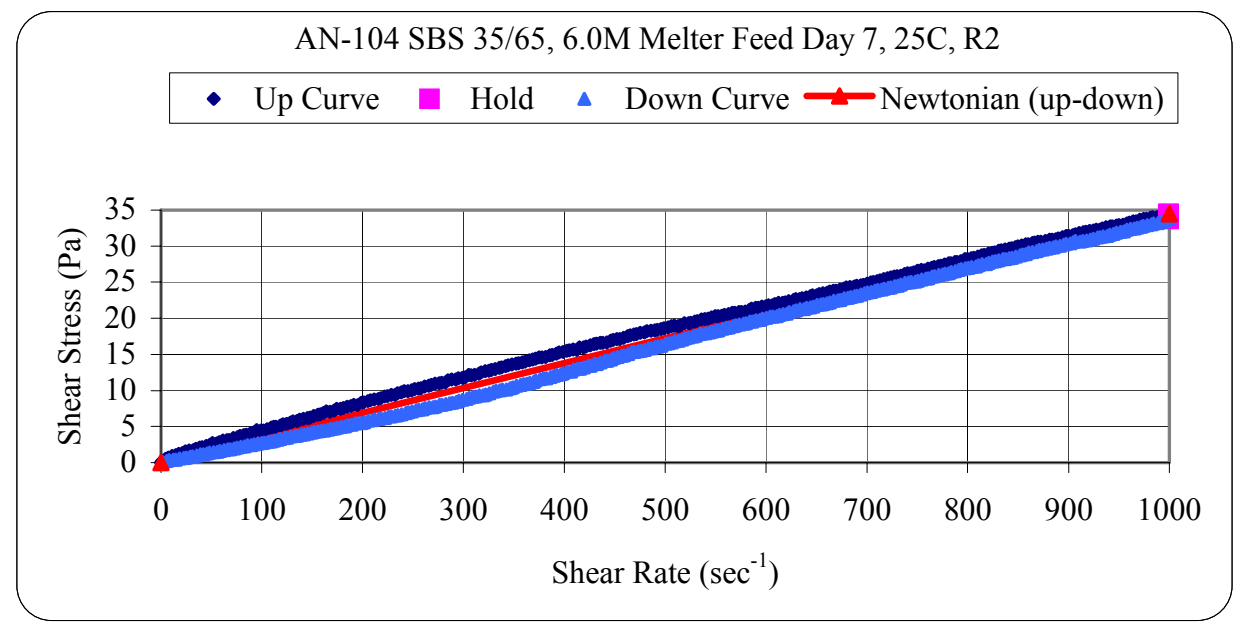

Figure D-18. 6.0 M Na AN104SBS3565 Melter Feed Flow Curve \#2, Day 7 at $25^{\circ} \mathrm{C}$ 
WSRC-TR-2004-00232, REVISION 0

SRNL-RPP-2004-00044, REVISION 0

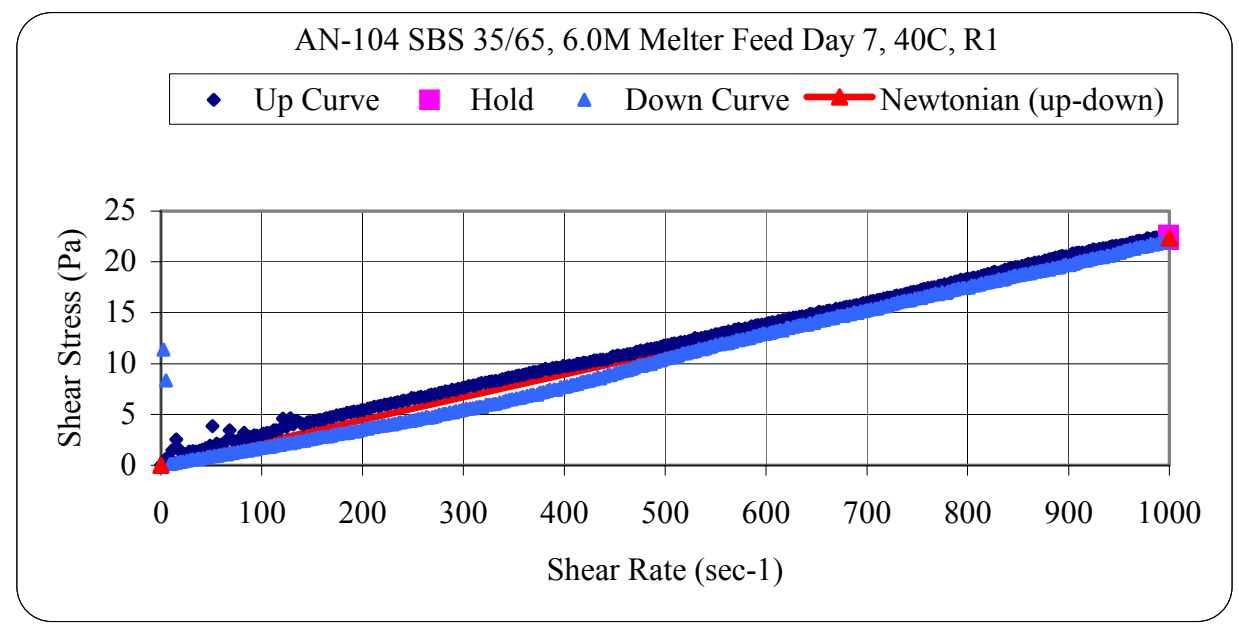

Figure D-19. 6.0 M NaAN104SBS3565 Melter Feed Flow Curve \#1, Day 7 at $40^{\circ} \mathrm{C}$

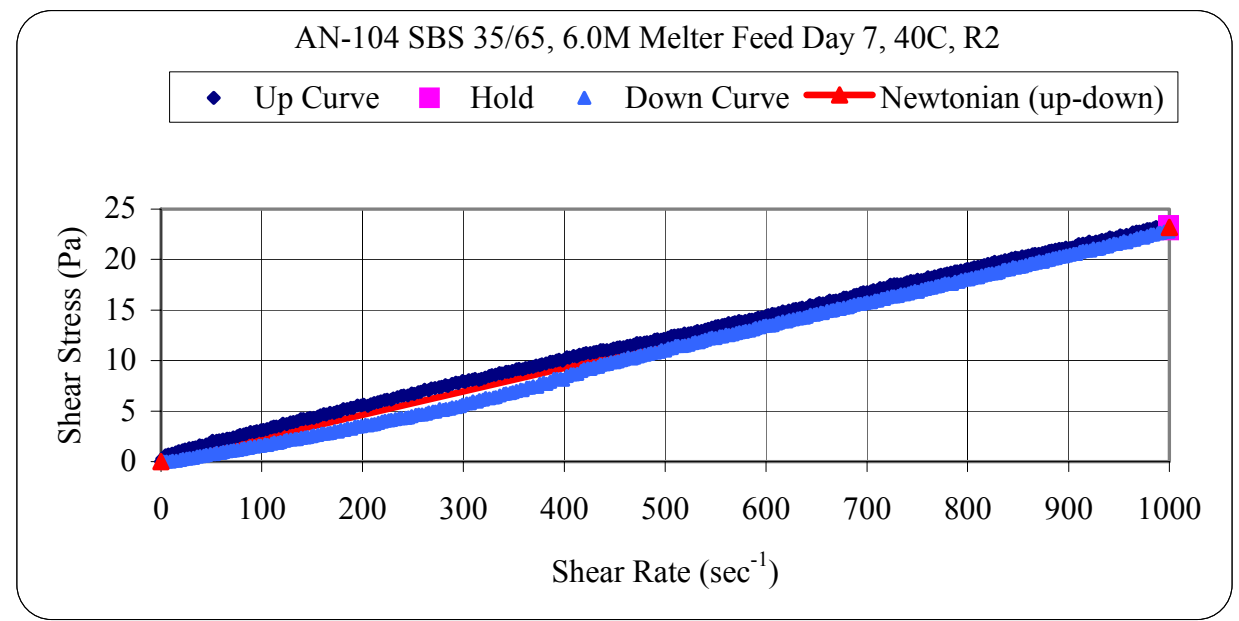

Figure D-20. 6.0 M Na AN104SBS3565 Melter Feed Flow Curve \#2, Day 7 at $40^{\circ} \mathrm{C}$

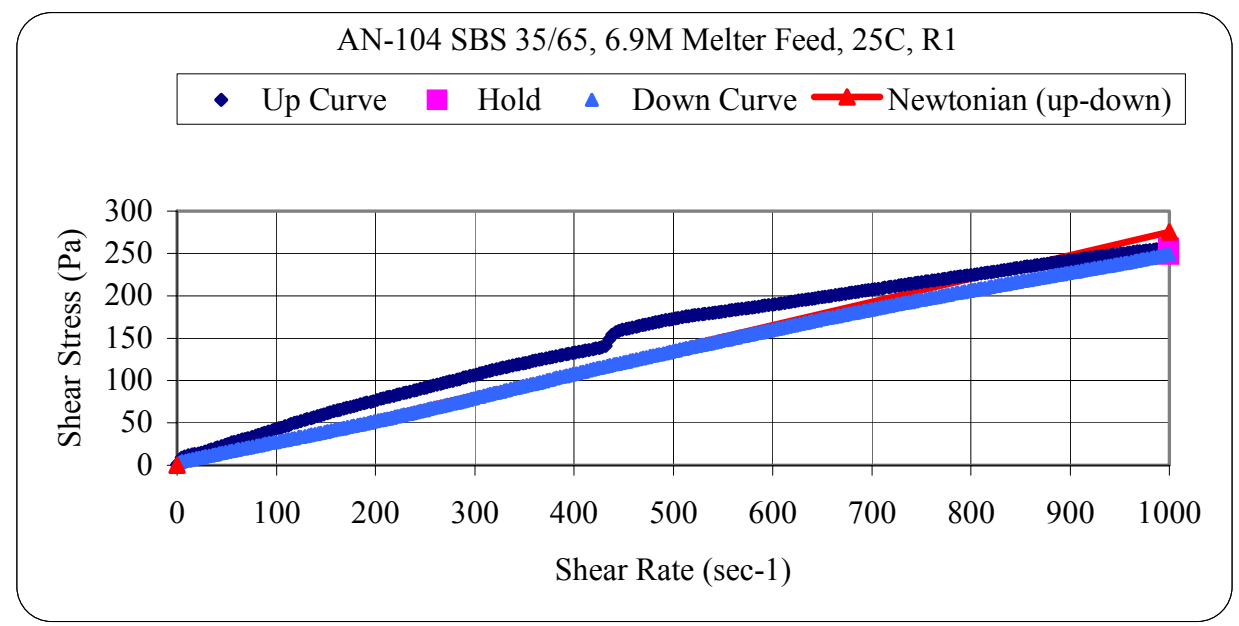

Figure D-21. 6.9 M Na AN104SBS3565 Melter Feed Flow Curve \#1 at $25^{\circ} \mathrm{C}$ 
WSRC-TR-2004-00232, REVISION 0

SRNL-RPP-2004-00044, REVISION 0

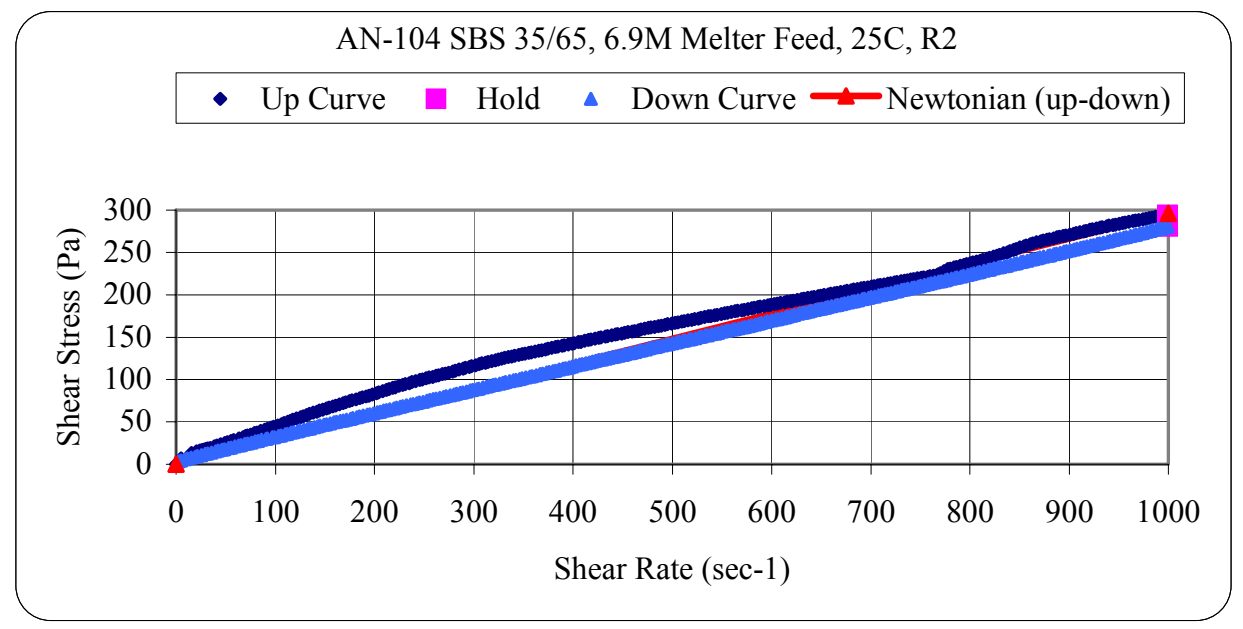

Figure D-22. 6.9 M Na AN104SBS3565 Melter Feed Flow Curve \#2 at $25^{\circ} \mathrm{C}$

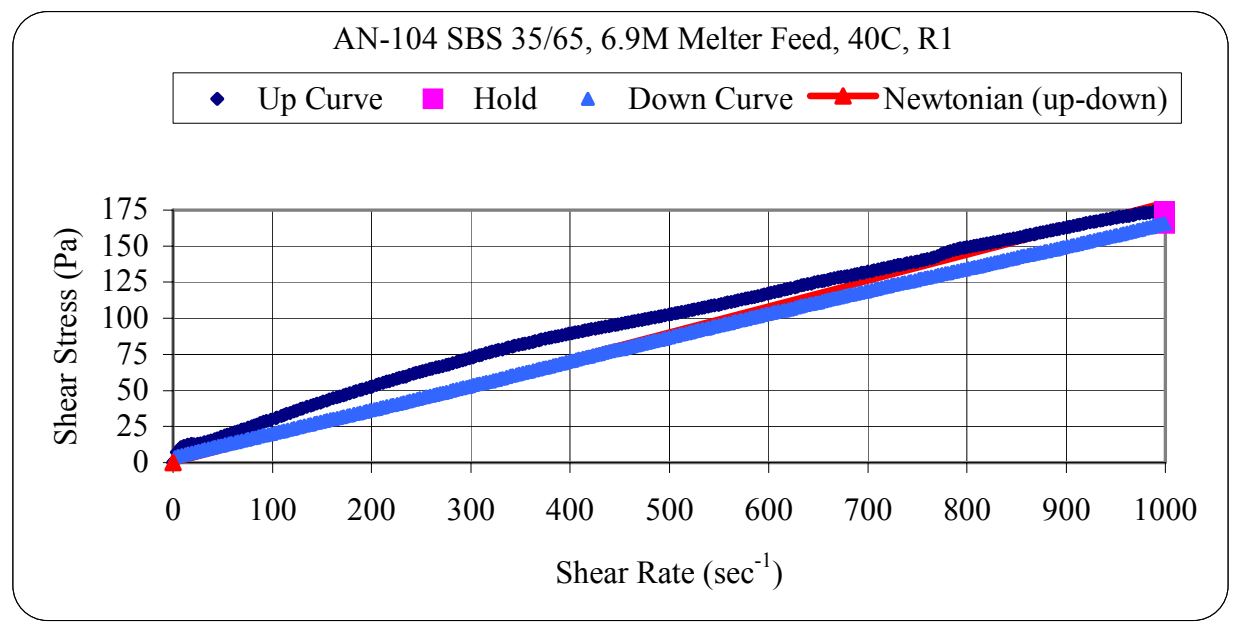

Figure D-23. 6.9 M Na AN104SBS3565 Melter Feed Flow Curve \#1 at $40^{\circ} \mathrm{C}$

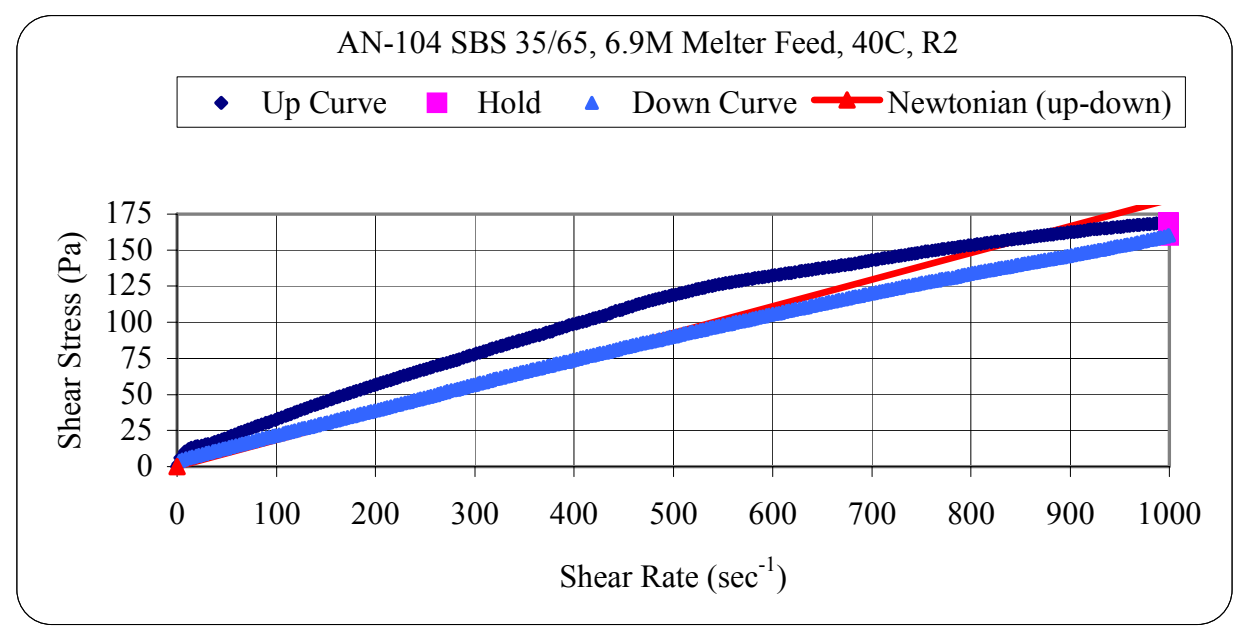

Figure D-24. 6.9 M Na AN104SBS3565 Melter Feed Flow Curve $\# 2$ at $40^{\circ} \mathrm{C}$ 
WSRC-TR-2004-00232, REVISION 0

SRNL-RPP-2004-00044, REVISION 0

This page intentionally left blank. 
WSRC-TR-2004-00232, REVISION 0

SRNL-RPP-2004-00044, REVISION 0

APPENDIX E.

PARTICLE SIZE DISTRIBUTION DATA 
WSRC-TR-2004-00232, REVISION 0 SRNL-RPP-2004-00044, REVISION 0

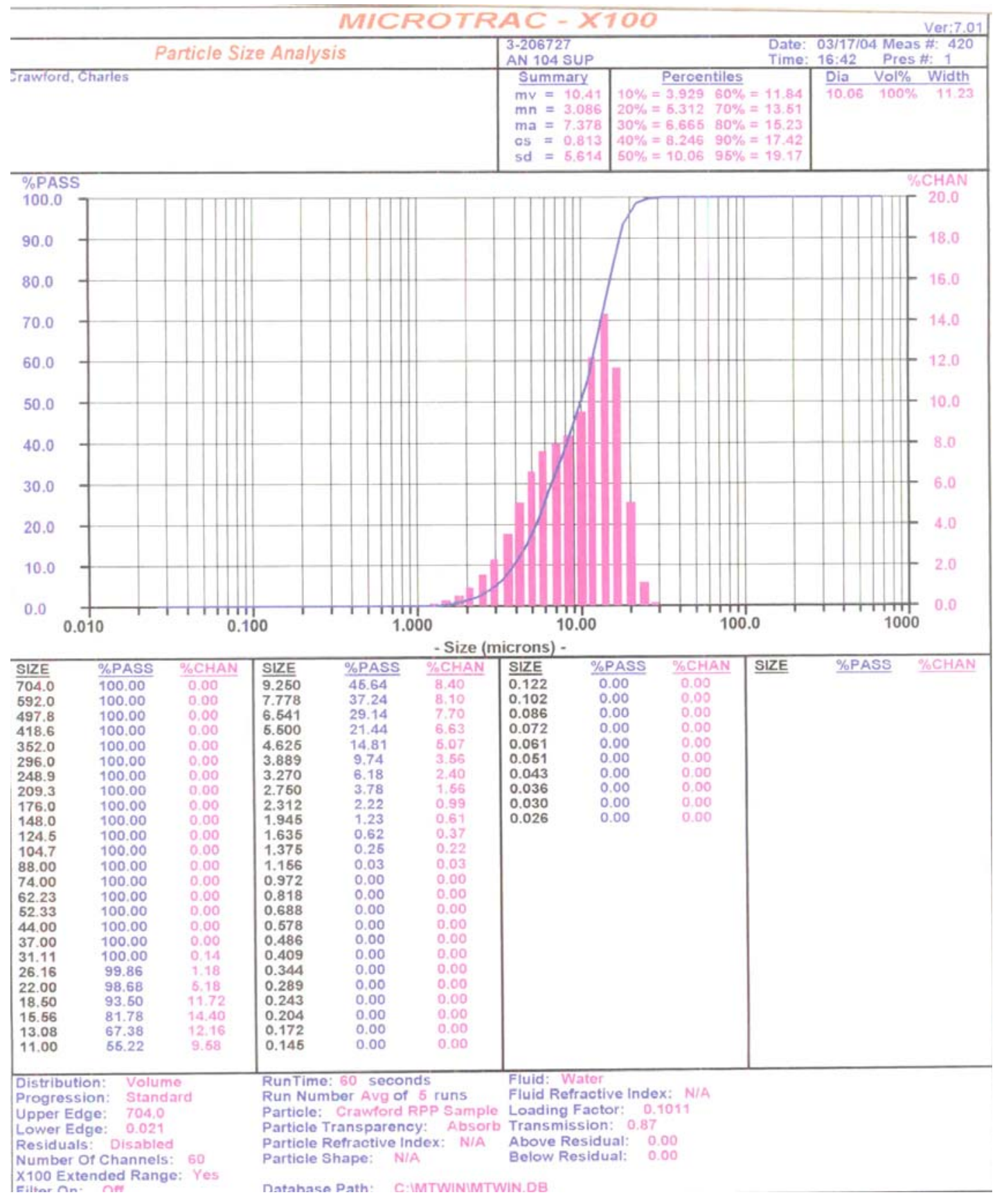

Figure E-1. AN104SBS3565 Pretreated Waste - PSD Volume Distribution

The "\% PASS" (blue colored) is the percentage of particles smaller or equal to the corresponding particle size. The "\% CHAN" (reddish color) is the percentage of particles between the particle size and the closest smaller particle size in the table. In the example above, $29.14 \%$ of the particles are below 6.541 microns and $7.70 \%$ of the particles are between 5.500 and 6.541 microns. The table labeled Dia, Vol, and Width are the distribution for one or more peaks/modes within the data. In this case, there is only one mode (e.g. one can have bi-modal, tri-modal, etc distribution). "mv" is the mean diameter of the volume distribution. "mn" is the mean diameter of the number distribution. "ma" is the mean diameter of the area distribution. "cs" is the calculated specific surface area $\left(\mathrm{m}^{2} / \mathrm{cc}\right)$ of the sample based on smooth, solid spherical particles. This number can in no way be related to a measured surface area, for example BET by adsorption. "sd" is the standard deviation for the distribution (not the variation about the mean). Specifically, "sd" is the difference between the diameters of the $84 \%$ and $16 \%$ particles that have passed divided by 2. "sd" does not provide an indication of the statistical error about the mean of multiple measurements. The table on the bottom provides the type of graph provided, operating parameters of the particle size analyzer and the number of sample runs. 
WSRC-TR-2004-00232, REVISION 0

SRNL-RPP-2004-00044, REVISION 0

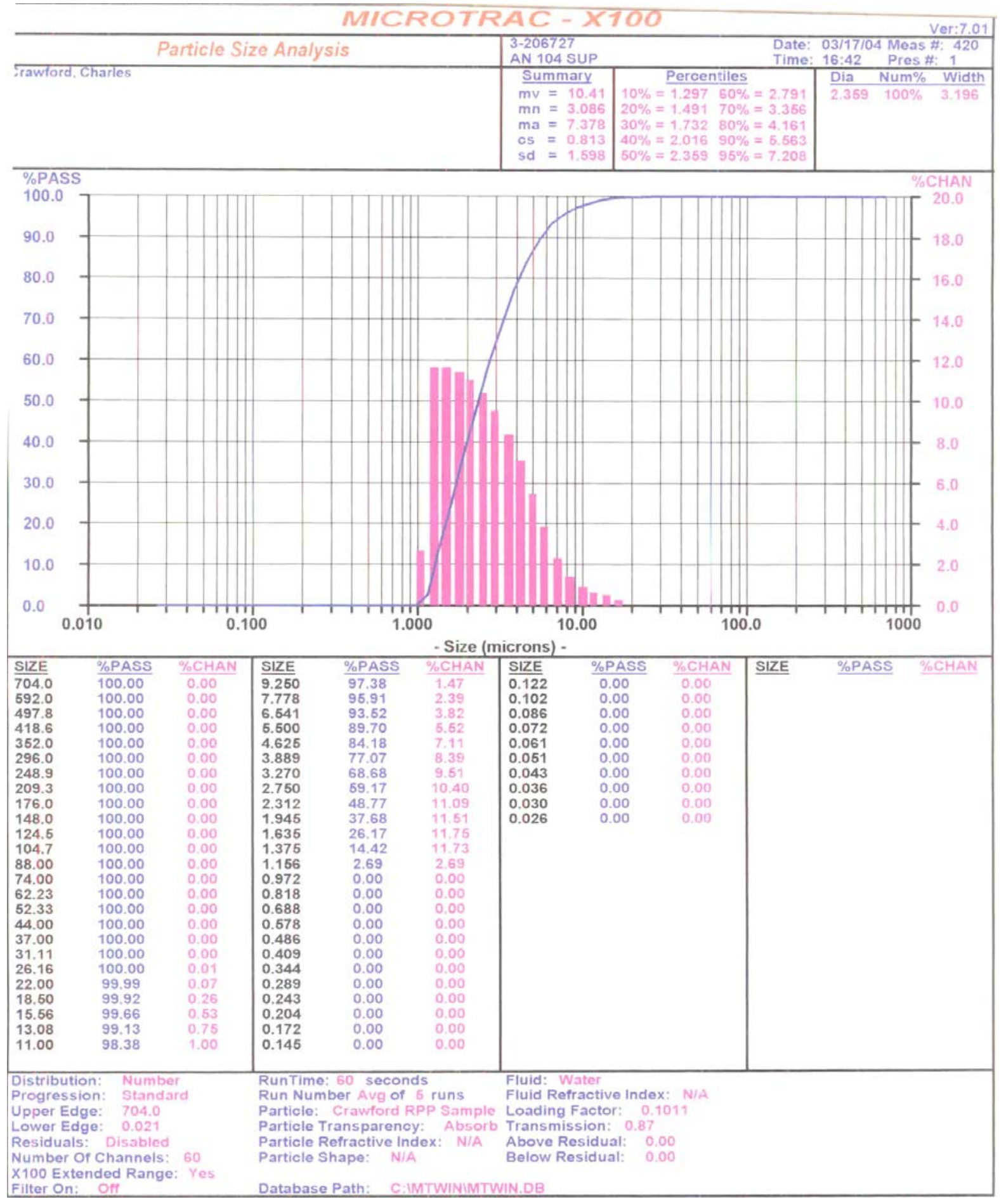

Figure E-2. AN104SBS3565 Pretreated Waste - PSD Number Distribution 
WSRC-TR-2004-00232, REVISION 0

SRNL-RPP-2004-00044, REVISION 0

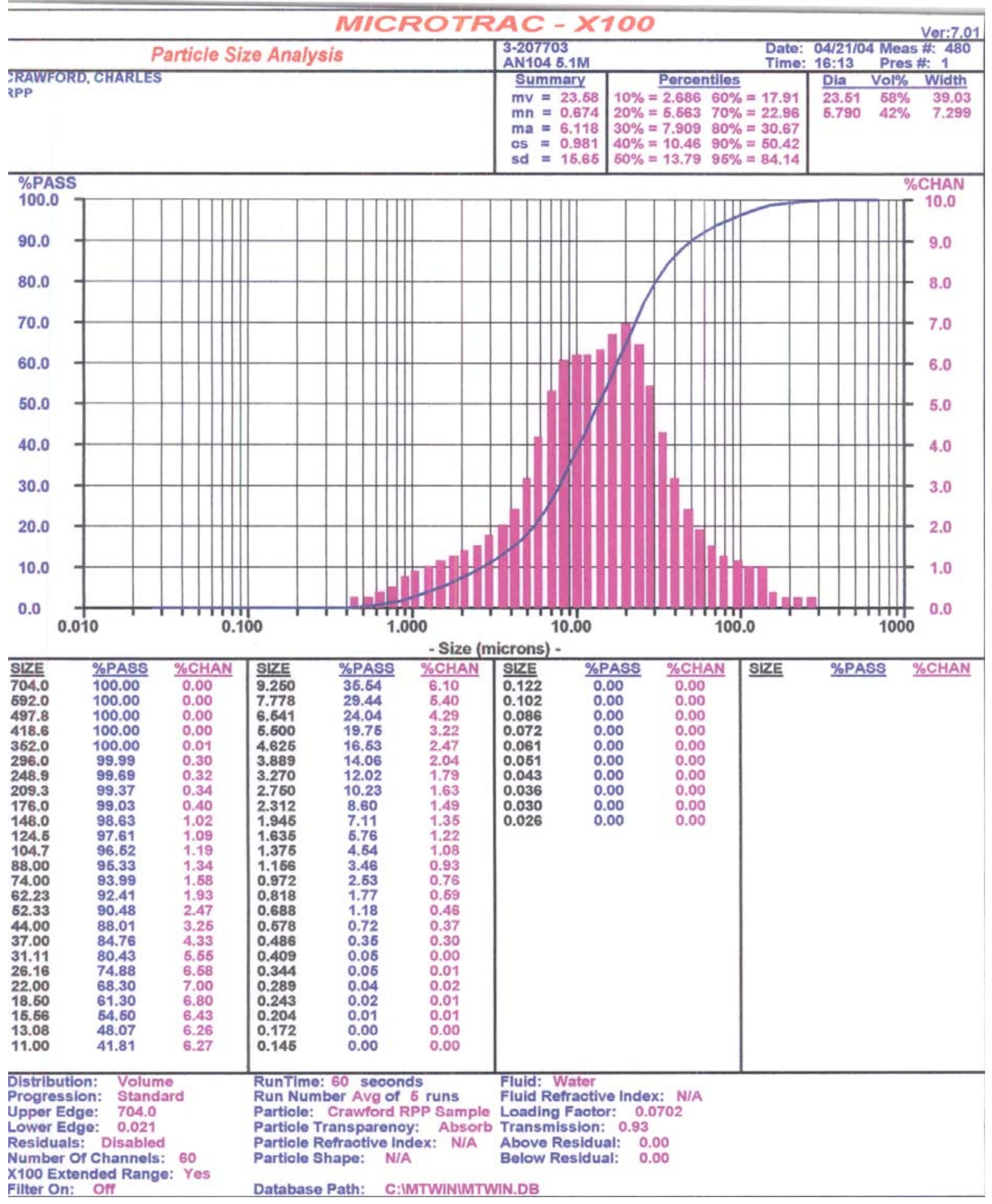

Figure E-3. 5.1 M Na AN104SBS3565 Melter Feed - PSD Volume Distribution 
WSRC-TR-2004-00232, REVISION 0 SRNL-RPP-2004-00044, REVISION 0

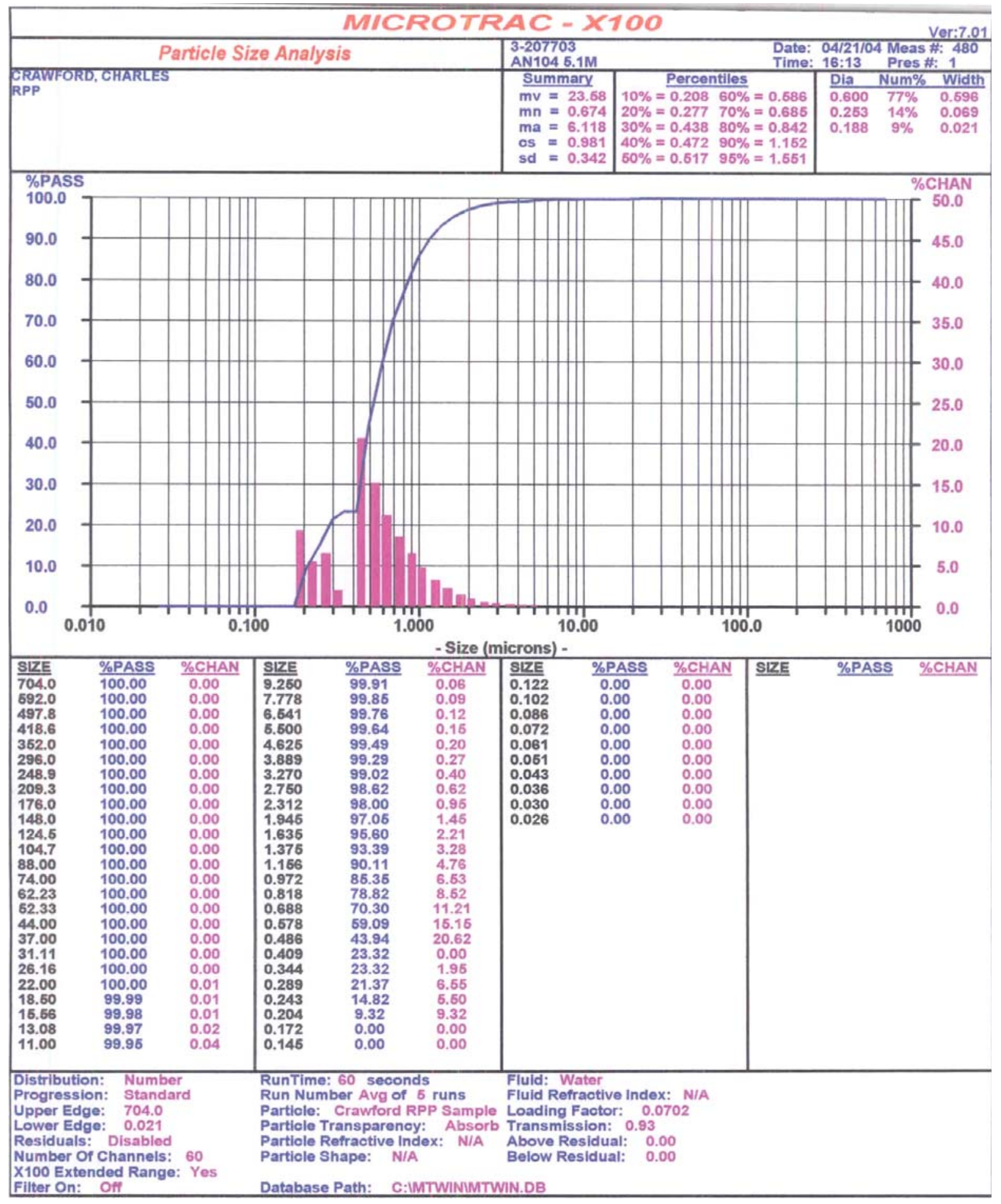

Figure E-4. 5.1 M Na AN104SBS3565 Melter Feed - PSD Number Distribution 
WSRC-TR-2004-00232, REVISION 0

SRNL-RPP-2004-00044, REVISION 0

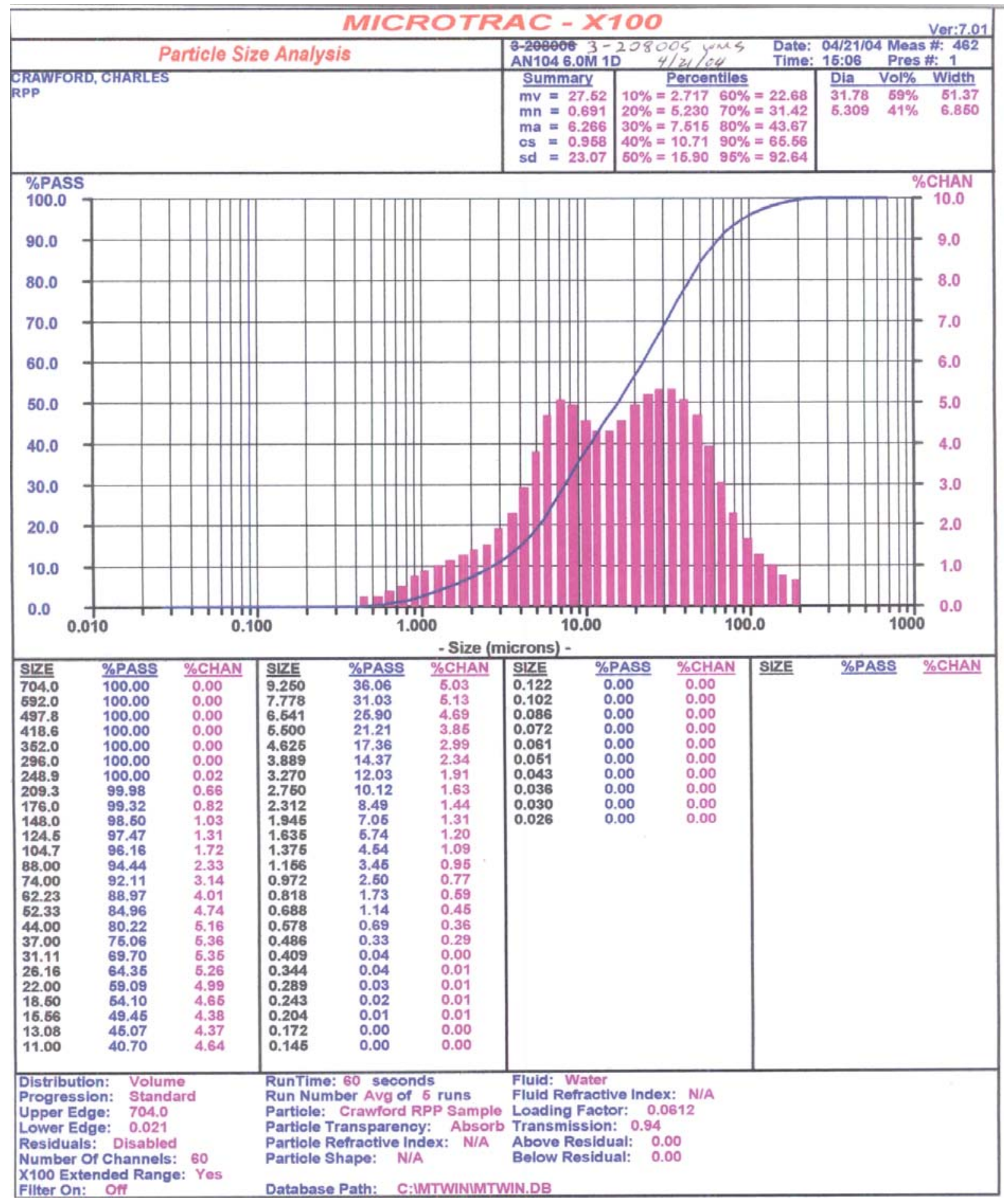

Figure E-5. 6.0 M Na AN104SBS3565 Melter Feed 1 Day - PSD Volume Distribution 
WSRC-TR-2004-00232, REVISION 0 SRNL-RPP-2004-00044, REVISION 0

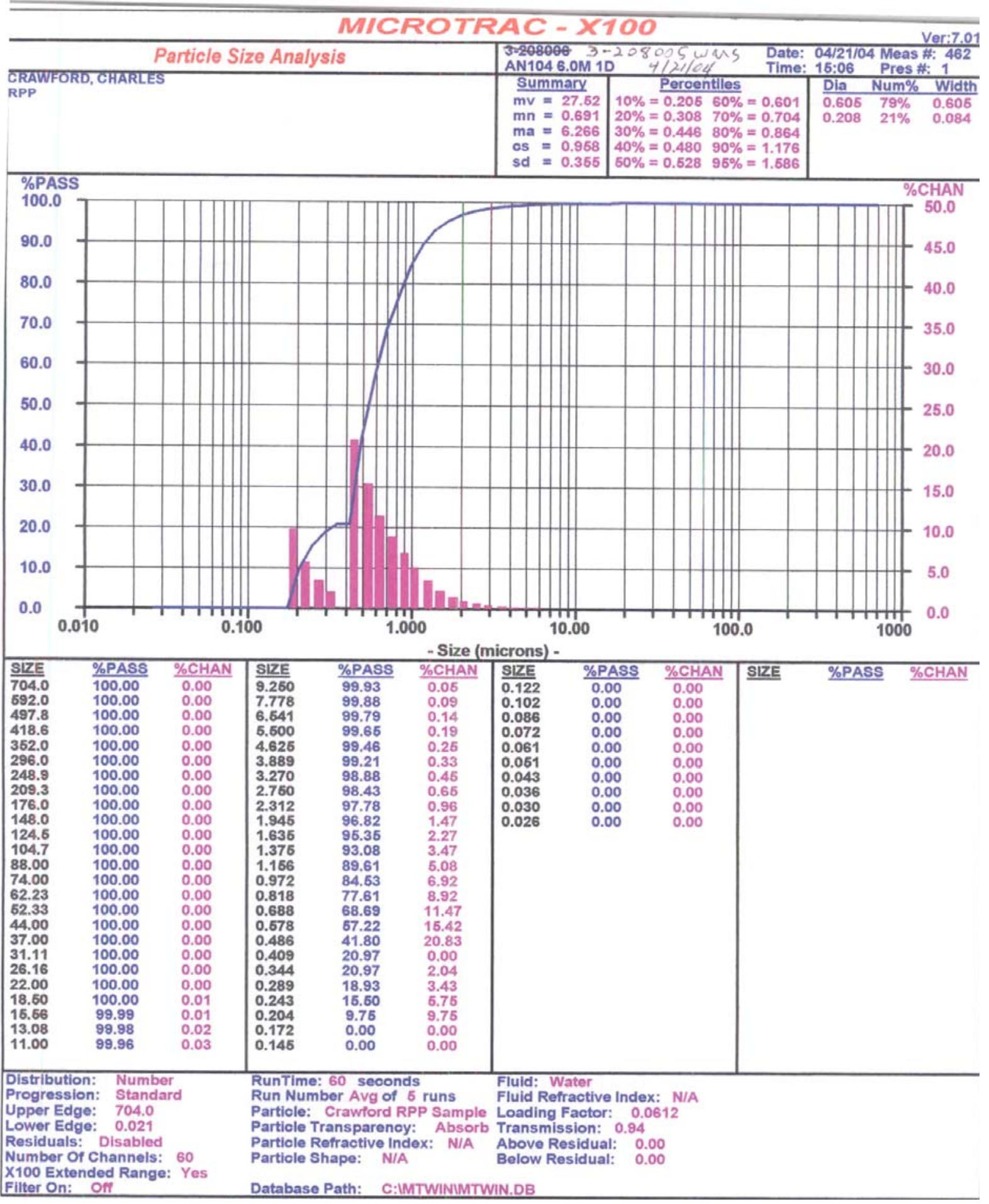

Figure E-6. 6.0 M Na AN104SBS3565 Melter Feed 1 Day - PSD Number Distribution 
WSRC-TR-2004-00232, REVISION 0

SRNL-RPP-2004-00044, REVISION 0

\section{MICROTRAC - XIOO}

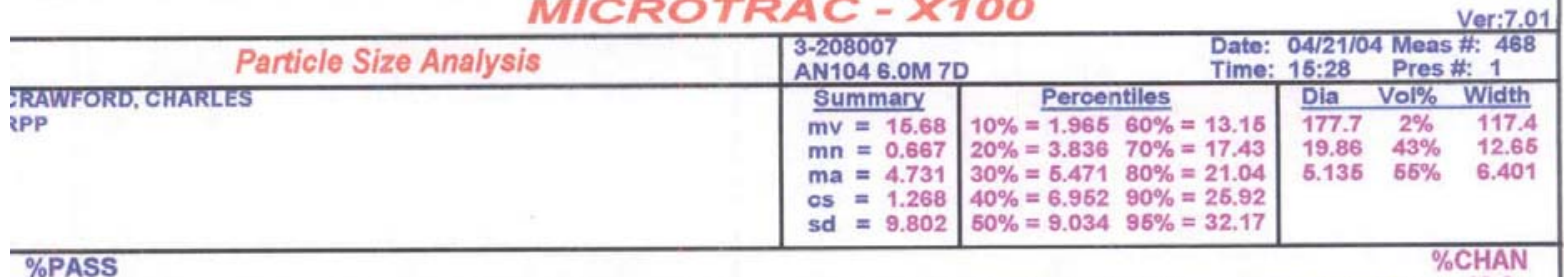

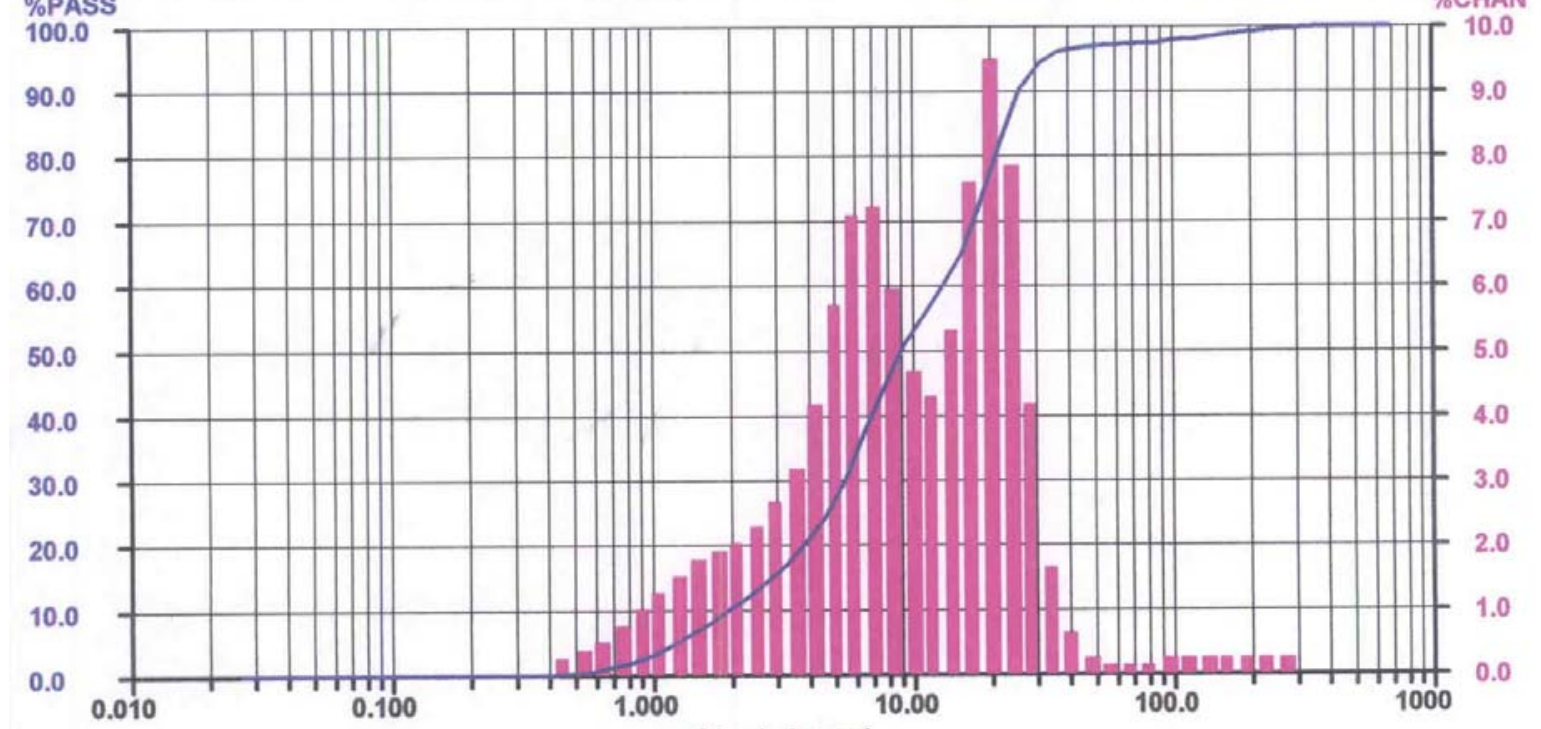

- Size (microns) -

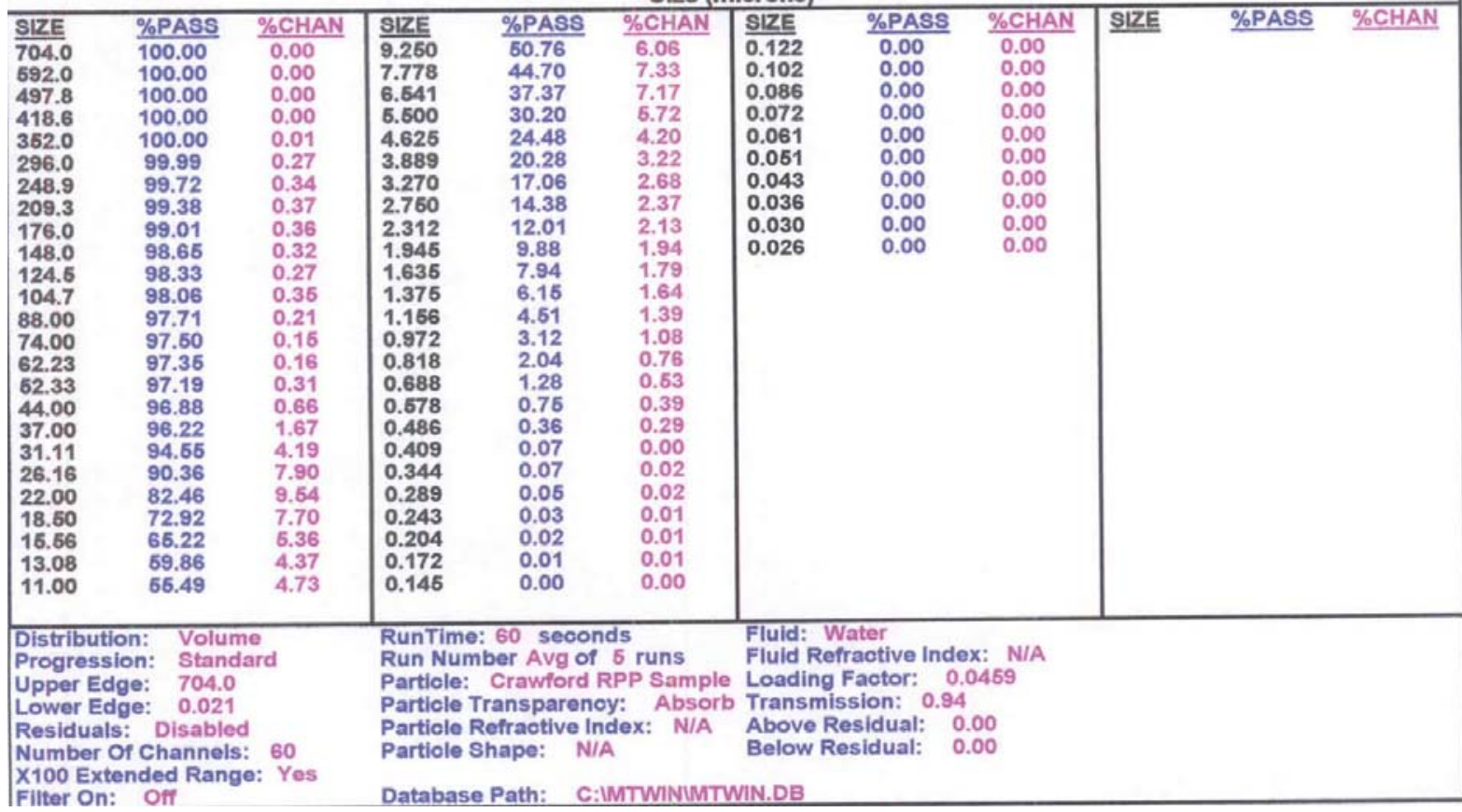

Figure E-7. 6.0 M Na AN104SBS3565 Melter Feed 7 Days - PSD Volume Distribution 
WSRC-TR-2004-00232, REVISION 0

SRNL-RPP-2004-00044, REVISION 0

MICROTRAC - XIOO

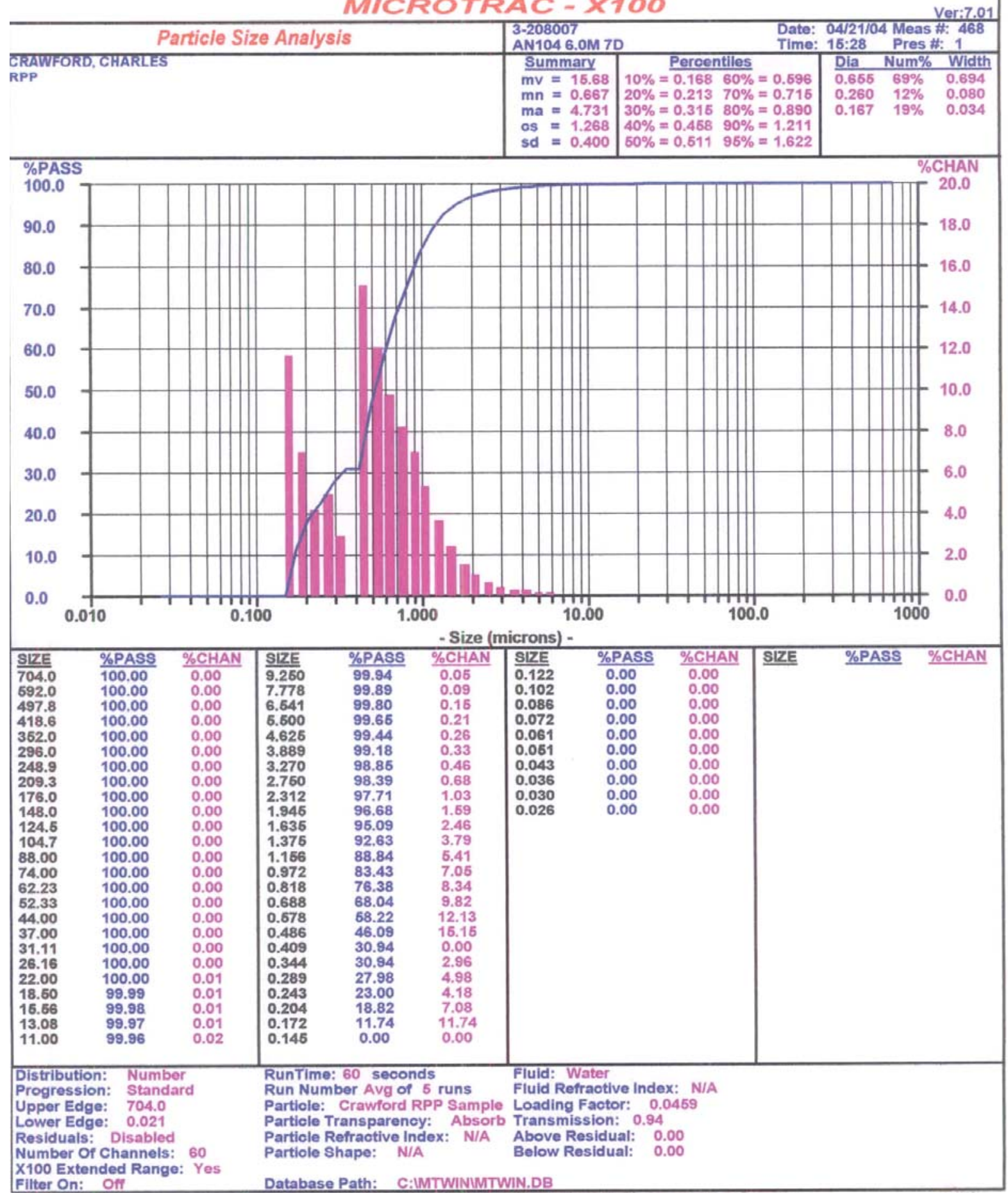

Figure E-8. 6.0 M Na AN104SBS3565 Melter Feed 7 Days - PSD Number Distribution 
WSRC-TR-2004-00232, REVISION 0 SRNL-RPP-2004-00044, REVISION 0

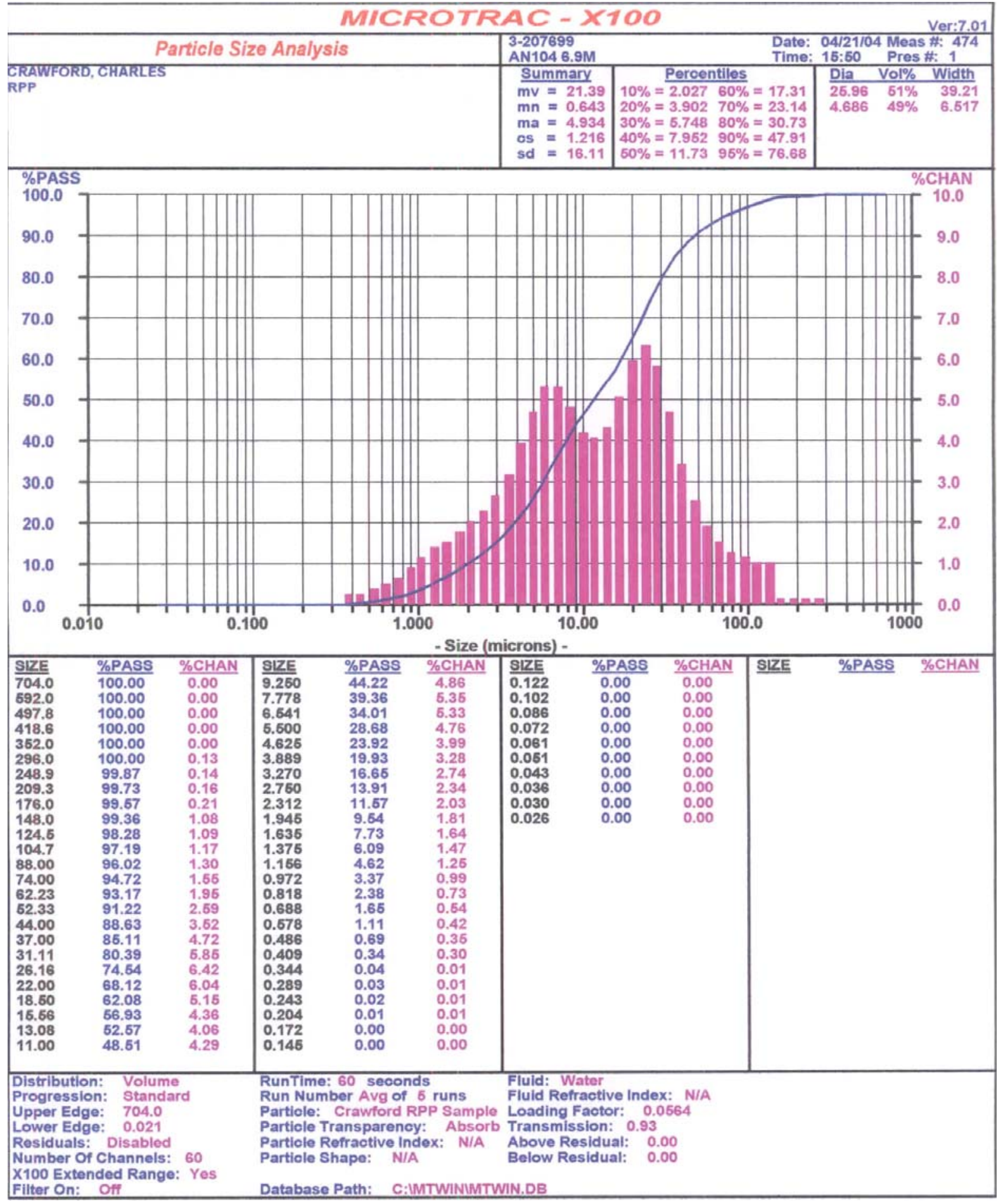

Figure E-9. 6.9 M Na AN104SBS3565 Melter Feed - PSD Volume Distribution 
WSRC-TR-2004-00232, REVISION 0 SRNL-RPP-2004-00044, REVISION 0

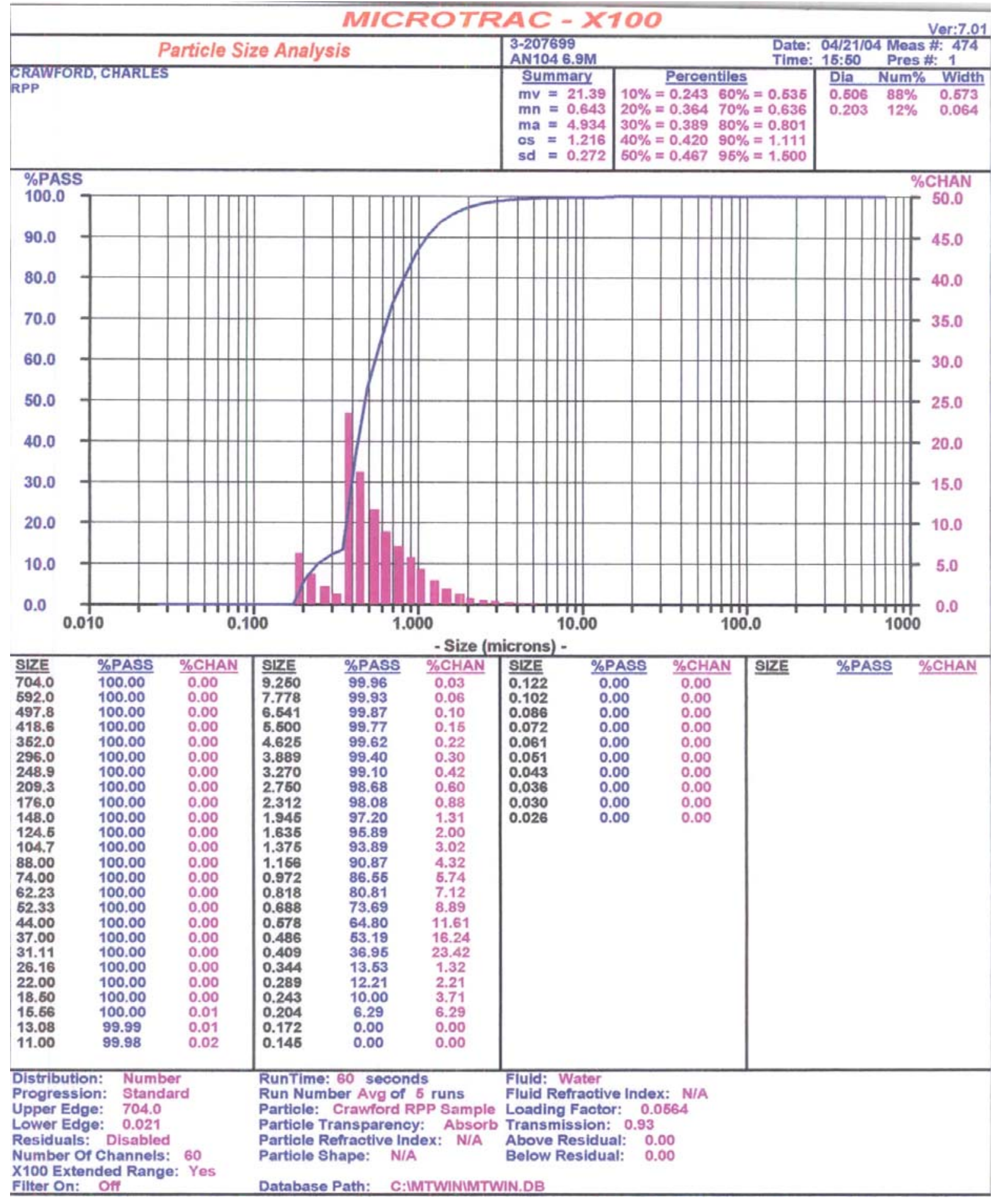

Figure E-10. 6.9 M Na AN104SBS3565 Melter Feed - PSD Number Distribution 
WSRC-TR-2004-00232, REVISION 0

SRNL-RPP-2004-00044, REVISION 0

Table E-1. Simulant LAW AN-104 Pretreated Waste Used For PSD Carrier Fluid

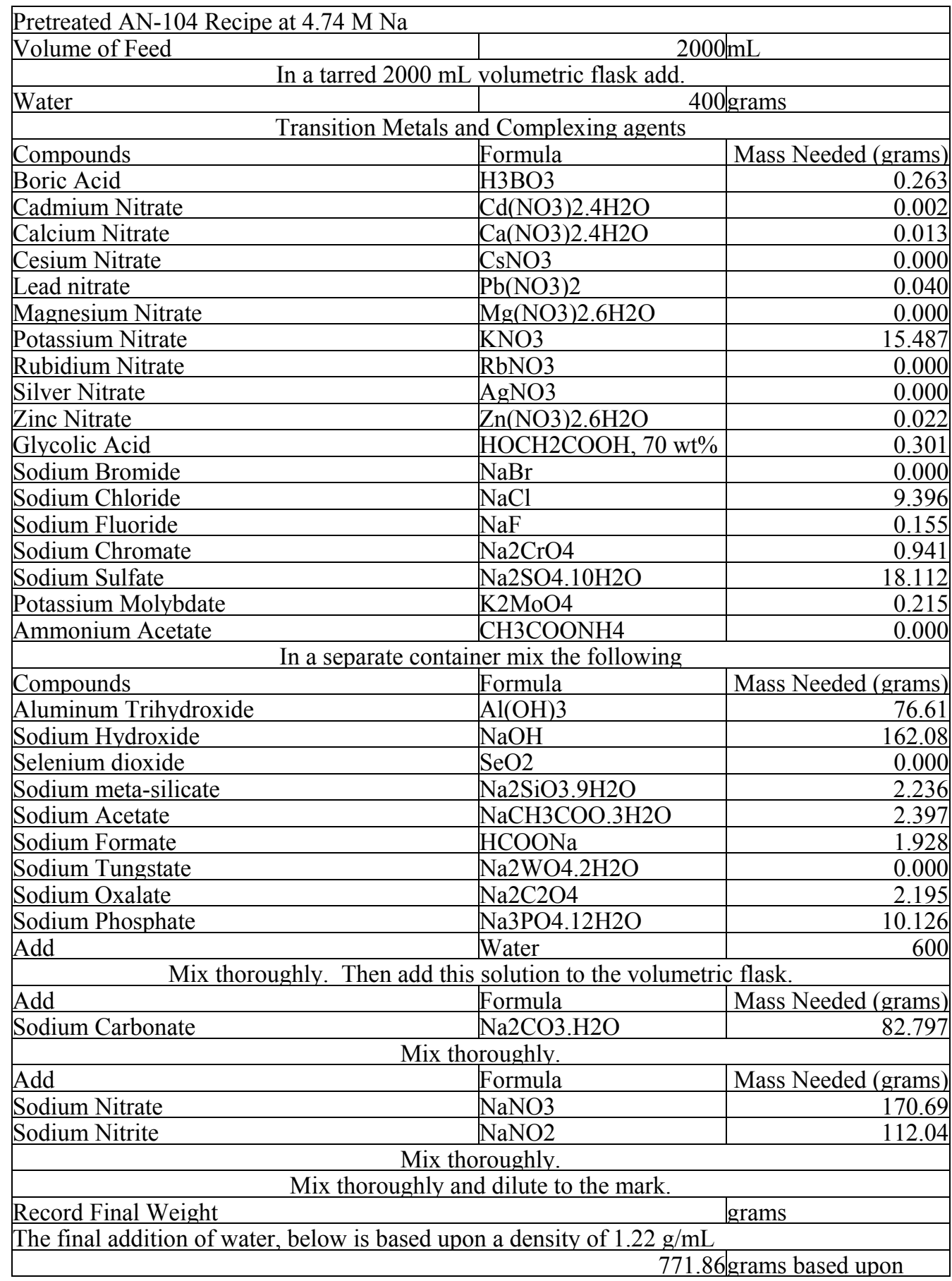


WSRC-TR-2004-00232, REVISION 0

SRNL-RPP-2004-00044, REVISION 0

This page intentionally left blank. 
WSRC-TR-2004-00232, REVISION 0

SRNL-RPP-2004-00044, REVISION 0

APPENDIX F.

WTP MEMO ON LAW CONTAINER CENTERLINE COOLING DATA 


\title{
Memorandum
}

$\begin{array}{llll}\text { To: } & \text { Chris Musick } & \text { Date: } & \text { October 16, } 2003 \\ \text { From: } & \text { Lawrence Petkus } & \text { CCN: } & 074181 \\ \text { Ext: } & 371-8436 & & \\ \text { Fax: } & 371-8346 & & \end{array}$

\section{Subject: LAW Container Centerline Cooling Data}

\author{
References: 1) 24590-LAW-TSP-RT-03-001 Test Specification "Filling Prototypic LAW \\ Containers with Glass" Rev. 0. June 12, 2003. \\ 2) TP-PLT-038 "RPP-WTP Pilot Melter Prototypic LAW Container and HLW \\ Canister Glass Fill Test Plan,” Rev. 0, Duratek Inc. August 8, 2003. \\ 3) REP-PLT-022 "RPP-WTP Pilot Melter Prototypic LAW Container and \\ HLW Canister Glass Fill Summary Report, ” Rev. 0. Duratek Inc. \\ September 30, 2003.
}

Testing has been completed where prototypic LAW containers were filled with glass to collect container centerline cooling (CCC) data. Container centerline cooling data was taken in accordance with references 1 and 2. The container-cooling portion of the test was done in accordance with a supplier Quality Assurance program compliant with NQA-1 (1989). In the test, three instrumented containers were filled with glass to greater than $95 \%$ fill height. The first two containers were filled at a production rate of 15 metric tons of glass per day and the last container; LT-003, was filled at 20 metric tons of glass per day. There was no discernable difference in the cooling profiles between the two fill rates.

To recommend a CCC profile for glass testing, the worst case, i.e. slowest, cooling curve was selected from the available data. Cooling times to $400 \mathrm{C}$ for the container, ranged from 3459 minutes to 3710 minutes. The cooling data, shown in Figure 1, is taken from container LT-002, collected at one-minute intervals. The thermocouple was positioned at the centerline 54 inches from the bottom of the canister. The peak temperature of $1114{ }^{\circ} \mathrm{C}$ was taken from the peak among the centerline data presented, which occurs in container LT-001. The cooling profile has been plotted over the data, with black diamonds, showing seven straight-line cooling segments. The segments were selected to reproduce the cooling profile at that point in the canister. Table 1 includes the $\mathrm{CCC}$ profile for crucible testing, which details each cooling segment. 
Although the centerline cooling data was contained in the test summary report, reference 3 , the final and complete test results will be issued in February, 2004. A complete description of the filling and cooling will be available at that time.

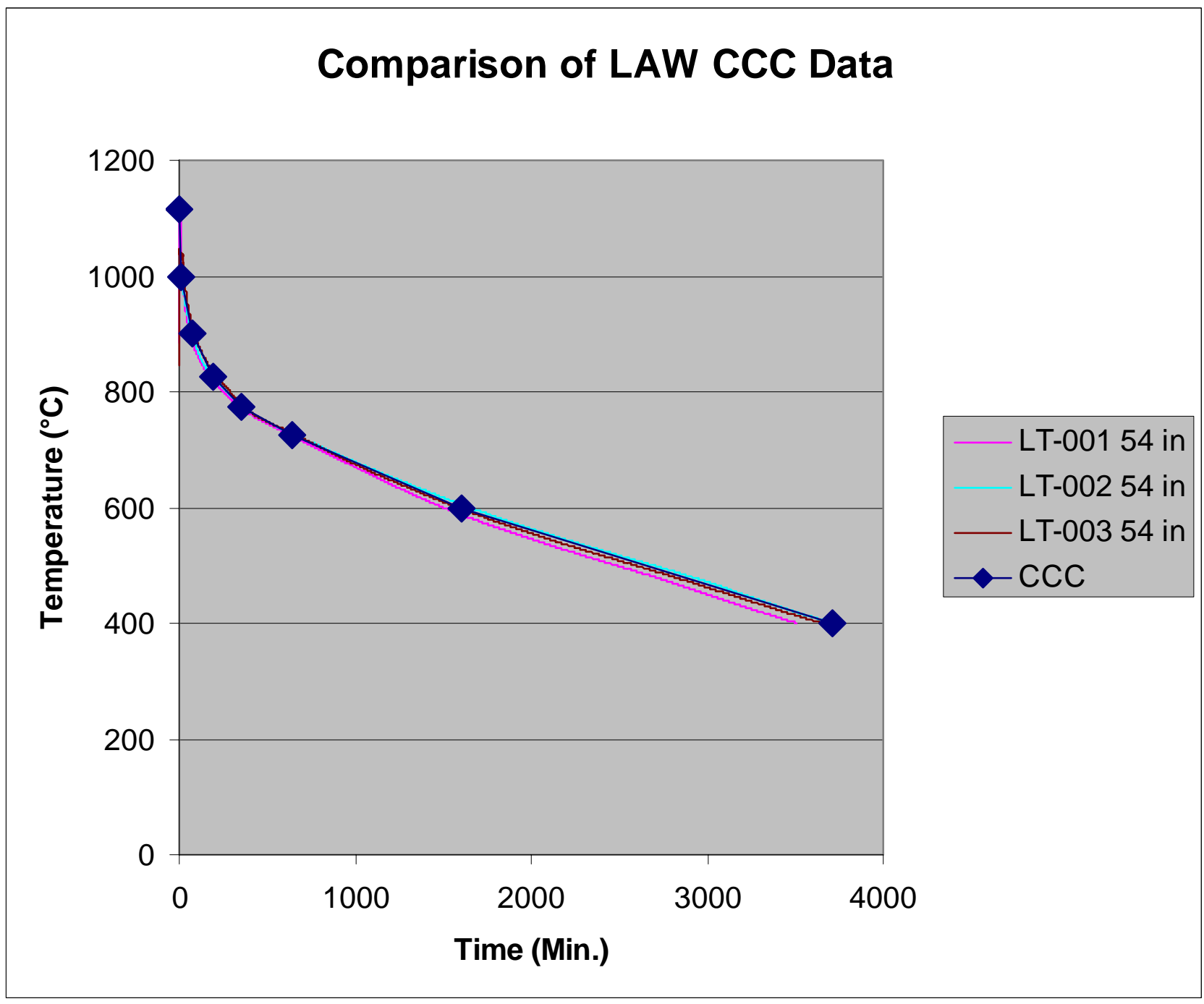

Figure 1. Time-temperature profile of LAW Container centerline at 54" along with line segments defined in Table 1. 
Table 1. LAW CCC Profile for Crucible Testing

\begin{tabular}{||c|c|c|c||}
\hline SEGMENT & $\begin{array}{c}\text { TIME } \\
\text { min }\end{array}$ & $\begin{array}{c}\text { START TEMP. } \\
{ }^{\circ} \mathrm{C}\end{array}$ & $\begin{array}{c}\text { RATE } \\
{ }^{\circ} \mathrm{C} / \mathrm{min}\end{array}$ \\
\hline 1 & $0-16$ & 1114 & -7.125 \\
\hline 2 & $16-73$ & 1000 & -1.754 \\
\hline 3 & $73-195$ & 900 & -0.615 \\
\hline 4 & $195-355$ & 825 & -0.312 \\
\hline 5 & $355-640$ & 775 & -0.175 \\
\hline 6 & $640-1600$ & 725 & -0.130 \\
\hline 7 & $1600-3710$ & 600 & -0.095 \\
\hline \hline
\end{tabular}

Lawrence Petkus

Research Engineer

Research and Technology

$\mathrm{R} \& \mathrm{~T} / 1 \mathrm{p}$

PDC

Barnes, SM

Carl, DE

Larson, DE

Lee, ED

Perez, JM
MS11-B

MS1-B

MS7-ESW

MS1-B

MS1-A

MS1-B
Peters, RD MS7-ESW

Prindiville, $\mathrm{K} \quad$ MS1-B

Viena, JD MS1-B

Wesick, JH MS1-B

Tamosaitis, WL MS1-B 